Departamento de Letras Modernas

Faculdade de Filosofia, Letras e Ciências Humanas

Universidade de São Paulo

\title{
A Árvore das Estórias: Uma proposta de tradução para Tree and Leaf, de J.R.R. Tolkien
}

(The Tree of Stories: A proposal of translation for Tree and Leaf, by J.R.R. Tolkien)

Dissertação de mestrado apresentada ao Programa de Pós-Graduação em Estudos Lingüísticos e Literários em Inglês

Reinaldo José Lopes - n. USP 2965629

Orientadora: Professora Doutora Lenita Maria Rimoli Esteves Agosto de 2006 


\section{RESUMO}

Este trabalho é uma proposta de tradução estrangeirizadora para a coletânea Tree and leaf, de J.R.R. Tolkien. Argumento que, adotando a perspectiva filológica que norteou o trabalho do autor britânico, bem como as idéias sobre as possibilidades da tradução propostas por Antoine Berman e Walter Benjamim, é viável recriar em português as conexões singulares entre língua, história e mito que marcam o trabalho de Tolkien. Apresento também minha tradução comentada dos quatro textos que compõem a coletânea - On-fairy stories, Mythopoeia, Leaf by Niggle e The homecoming of Beorhtnoth Beorhthelm's son, os três primeiros na versão completa - de maneira a demonstrar como essa possibilidade pode tomar forma na tradução em si.

PALAVRAS-CHAVE: Tolkien, estória de fadas, tradução estrangeirizadora, filologia, anglo-saxão.

\section{ABSTRACT}

This work is a proposal of a foreignizing translation for the anthology Tree and leaf, by J.R.R. Tolkien. I argue that, by adopting the philological perspective that informed the work of that British author, as well as the ideas on the possibilities of translation put forward by Antoine Berman and Walter Benjamim, it is feasible to recreate in Portuguese the unique conexions between language, history and myth that are a trademark of Tolkien's work. I also present my translation and commentary of the four texts that make up the anthology - On-fairy stories, Mythopoeia, Leaf by Niggle e The homecoming of Beorhtnoth Beorhthelm's son, of which the first three are presented in their entirety - in order to demonstrate how this possibility may develop in an actual Portuguese translation.

KEYWORDS: Tolkien, fairy-stories, foreignizing translation, philology, Anglo-Saxon. 


\section{Agradecimentos}

Em circunstâncias como a presente, o velho clichê é, mais do que nunca, verdadeiro: os agradecimentos são sempre inferiores ao número e ao empenho das pessoas que, de um modo ou de outro, permitiram que esse trabalho fosse possível.

Para começar, agradeço à mulher que eu amo, Tania Mara Antonietti Lopes, que eu infectei com o vírus tolkieniano logo de cara e que tem me acompanhado na exploração desse mundo inesgotável.

Rendo graças à minha orientadora, Lenita Maria Rimoli Esteves, pelas doses inexauríveis de bom humor e paciência com um aluno que, embora sempre empolgado com seu tema, mostrou-se menos do que célere na execução do trabalho e um tanto quanto desrespeitoso do good procedure acadêmico. Agradeço também às minhas colegas (continuo sendo a única pessoa do sexo masculino entre os orientandos de Lenita): Solange, Zsuzsanna, Dircilene, Stela, Kátia, Vera, Marly, Jerusa e Célia.

Aos velhos e novos amigos, que respiraram este projeto durante várias de suas fases e compreenderam quando o meu tempo precisou ser dedicado a ele (e não a eles): Salvador Nogueira, Claudio Angelo, Daniel Perassolli, Rafael Bettega, Fábio Bettega, Paula Rodrigues, Victor Romualdo Francisco e Maria Claudia Perassolli.

Obrigado também à minha família e ao carinho sempre presente dos meus pais.

E, finalmente, mas nem de longe menos importante, ao sonho de J.R.R. Tolkien e à fé que ele tinha, e que também é a minha, em $i$ Eru $i$ or ilyë mahalmar ëa tennoio - o Único que está acima de todos os tronos para sempre. 


\section{Epígrafe}

"I don't think you realize, I don't think any of us realize, the force, the daimonic force that the great myths and legends have. From the profundity of the emotions and perceptions that begot them, and from the multiplication of them in many minds - and each mind, mark you, an engine of obscured but unmeasured energy. They are like an explosive: it may slowly yield a steady warmth to living minds, but if suddenly detonated, it might go off with a crash. Yes: it might produce a disturbance in the real primary world."

(J.R.R. Tolkien, The Notion Club Papers). 


\section{Sumário}

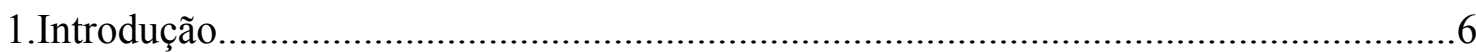

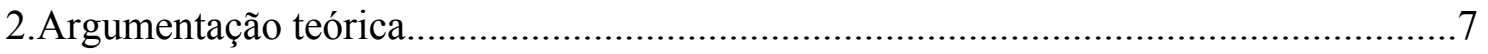

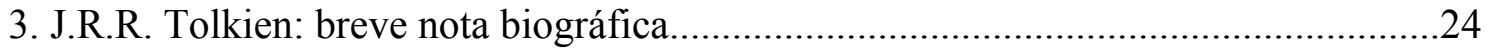

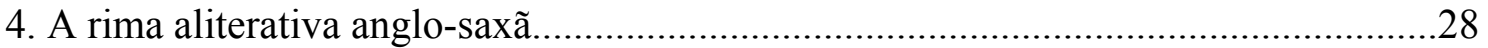

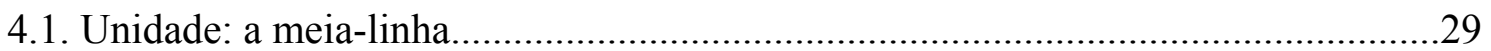

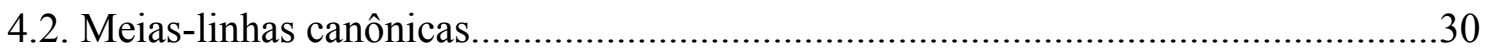

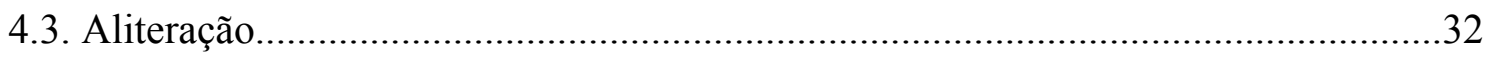

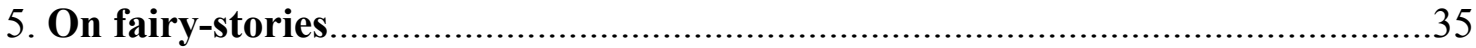

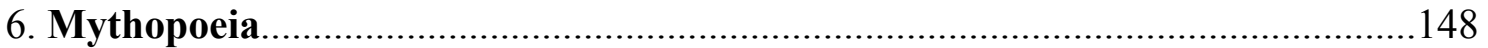

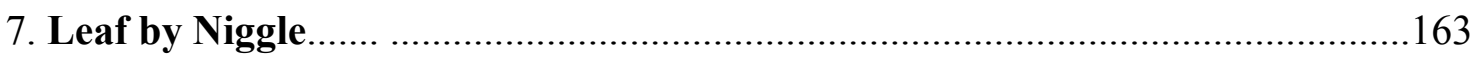

8. The homecoming of Beorhtnoth Beorhthelm's son........................204

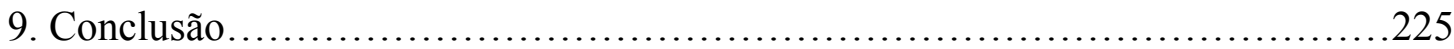

10. Fontes

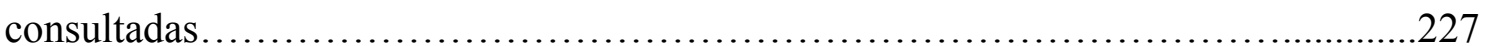




\section{Introdução}

O presente trabalho é uma tradução comentada da coletânea Tree and leaf, do escritor britânico J.R.R. Tolkien (1892-1973). O livro compreende o ensaio On fairystories, o poema Mythopoeia, o conto Leaf by Niggle e o poema em forma de diálogo dramático The homecoming of Beorhtnoth Beorhthelm's son, nenhum dos quais conta ainda com uma tradução para o português. Apresento aqui, da forma mais sucinta possível, a estrutura que utilizei na tentativa de realizar essa tarefa a contento.

Inicio o trabalho com uma breve argumentação teórica, que trata dos princípios que nortearam a tradução em todos os seus aspectos. Argumento que o ponto de vista de autores como Antoine Berman, Walter Benjamin e a escola romântica alemã é o mais adequado para abordar o texto tolkieniano. Em seguida, apresento uma nota biográfica cobrindo os principais momentos da vida do autor. Ainda à guisa de material introdutório, a seção seguinte aborda a métrica aliterativa anglo-saxã, empregada por Tolkien em The homecoming of Beorhtnoth Beorhthelm's son e muito pouco conhecida e estudada em língua portuguesa, o que justifica uma exposição mais detalhada de suas características formais.

Finalmente, apresento trechos selecionados de cada texto traduzido. Cada um deles é composto de uma nota introdutória que aborda de forma panorâmica os problemas de tradução mais importantes do texto original e da tradução lado a lado, à maneira de uma edição bilíngüe, e de comentários sobre pontos específicos do texto na forma de notas de rodapé. 


\section{Argumentação teórica}

Sempre é seguro começar com um lugar-comum: os desenvolvimentos mais recentes da teoria da tradução (ou, ao menos, os que estão mais na moda) parecem se distanciar cada vez mais da velha ênfase normativa, que tentava diferenciar de forma explícita a "boa" tradução da "má". (As aspas, como artifício politicamente correto), também andaram se tornando indispensáveis.) No lugar das velhas recomendações sobre como proceder para que emerja do trabalho uma tradução "fiel", a atenção se volta cada vez mais para uma análise das condições reais da tradução e dos textos produzidos - em resumo, ela se deslocou do "dever ser" para o "é". Lefevere (1982, p. 234), ao abordar a natureza da tradução por esse ângulo desencantado, exprime de forma bastante enfática o fato de que mesmo as traduções consideradas mais pedestres, baseadas numa aparente distorção ou compreensão errônea do texto original, acabam se tornando $a$ imagem do autor traduzido na língua de chegada. Ele quase chega a afirmar que essas refrações, como as chama, são tão mais influentes quanto mais distorcem “opticamente", no processo complicado da mudança de um meio lingüístico para outro, a aparência do autor original. (Não é a outra a razão de Lefevere utilizar o termo "refração").

Dentro dos sistemas literários de cada cultura, considerados pelo autor como essencialmente conservadores, tais traduções encaixam-se no contexto mais amplo das demais refrações: análises teóricas, resenhas de romances e peças, adaptações para o teatro, o cinema e a televisão etc. No caso da imensa maioria dos clássicos (e a despeito do insistente conselho dos especialistas em literatura para conhecer as obras na sua língua e no seu contexto originais), essas refrações provavelmente serão a única via de acesso aos textos canônicos para a grande maioria do público (leitor e não-leitor). Assim, Lefevere considera mesmo contraproducente despejar sobre essas refrações a torrente costumeira de julgamentos de valor: importa mais entender as condições que as tornam veículos relevantes do status quo cultural.

Da mesma maneira, Toury (1978/1995, p. 202) chama a atenção para o conjunto de normas culturais que funcionam como framework (camisa-de-força seria, às vezes, uma descrição mais exata) para o trabalho do tradutor. Os níveis de tolerância ao uso de estratégias de tradução que retenham características formais menos "naturalizáveis" do texto original variam em função dessas normas. Além das óbvias restrições mais ou menos externas ao ambiente literário (os hábitos de leitura do mercado para o qual o 
texto está sendo traduzido, a censura, o mecenato das mais diversas instituições), as normas variam ao sabor das transformações históricas dos gostos e escolas artísticas.

“Thus, as changes of norms occur, formerly 'progressive' translators may soon find themselves just 'trendy', or on occasion as even downright 'passé"' (TOURY, 1978/1995, p.2005).

De fato, atentar para essas questões tornaria bem menos justificável o procedimento de culpar única e exclusivamente o provincianismo ou a inépcia do tradutor cujo trabalho final não agradou ao crítico. O pensamento desses autores busca ser descritivo antes de prescritivo (ver também Even-Zohar, 1978/1990) e, em grande medida, tem alcançado esse objetivo.

Tal olhar sobre as condições em que o ato de traduzir acontece inevitavelmente tem uma dimensão política (Even-Zohar [1978/1990, p. 193] já chamava a atenção para os diferentes papéis que a tradução é capaz de desempenhar dentro de culturas “dominantes" e "dominadas"). Foi seguindo essa trilha que autores como Tymoczko (2000, p. 23-47) abordaram a importância da tradução em contextos coloniais ou póscoloniais. A autora norte-americana examinou mais detidamente o caso da luta pela independência da Irlanda, na qual as antigas lendas gaélicas, como as do herói Cú Chulainn, foram usadas como modelo para o combate heróico contra o domínio britânico. O tema da refração reaparece de forma proeminente aqui: peças de teatro, poemas e literatura infantil sobre Cú Chulainn viraram mania irlandesa no fim do século XIX e começo do século XX. E, o que talvez seja o mais curioso, o processo de refração da lenda transformou o herói numa figura palatável para o próprio establishment vitoriano-eduardiano que os irlandeses estavam combatendo: de mulherengo cheio de piolhos, capaz de ficar com as feições deformadas em meio à fúria da batalha, surge um guerreiro pudico e nobre, cristianizado mesmo sem ser cristão. Trata-se, sem dúvida, de mais uma demonstração da força do sistema de normas sobre o tradutor.

Não admira que uma situação como a exemplificada acima pela história irlandesa - a tradução transformada em arma de resistência anticolonial, envolvida numa transformação ideologicamente radical dos textos com os quais lida, mas ainda assim apresentada como fenômeno "neutro - tenha provocado exatamente a reação 
oposta à impassividade pregada pelos teóricos dos estudos descritivos de tradução. As preocupações com a práxis, com o dia-a-dia de um profissional dilacerado entre as aspirações artísticas de seu ofício e o sistema de normas literárias e não-literárias, levam naturalmente a tentativas de revalorizar a figura do tradutor, de diminuir sua suposta invisibilidade, como argumenta, por exemplo, o teórico norte-americano Lawrence Venuti na introdução de Rethinking translation. Para esse autor, o fato de os tradutores estarem relegados ao low end da hierarquia literária tem tudo a ver com o pensamento que atribui genialidade e permanência artística ao original e relega os textos traduzidos a meras muletas ou substitutos imperfeitos - sem levar em consideração o fato de que, para muitos dos leitores, eles representam a única possibilidade de acesso a determinadas obras "fundamentais", como Lefevere também aponta.

Avaliar os prós e os contras dessas abordagens "pé-no-chão", desencantadas ou engajadas, geraria uma discussão teórica muito além do escopo do presente trabalho. Mas, nesse sentido, tal tendência (relativamente) recente dos estudos da tradução apresenta uma vantagem, justamente por dirigir a atenção do tradutor para cada texto e autor individuais, em vez de tentar buscar soluções universais. Além disso, o próprio fato de a tendência descritiva chamar a atenção para as normas e consensos culturais subjacentes ao ato de traduzir fornece, no mínimo, os primeiros componentes para um antídoto a essas tendências, os primeiros elementos para uma tomada de consciência em relação a elas. Uma das premissas fundamentais que guiam este trabalho é a convicção de que o tradutor, embora não possa mais se refugiar numa invisibilidade até certo ponto confortável, só pode trabalhar em função do texto e do autor da língua de partida. Com isso espero começar a deixar claro que a intenção aqui é (depois de revisitar de forma inevitavelmente sucinta as tendências mais recentes da teoria da tradução e examiná-las em busca de caminhos possíveis para um trabalho como o que está sendo ora apresentado) voltar minha atenção para as características mesmas da obra que pretendo traduzir. Em se tratando dos textos com os quais trabalharei, pretendo demonstrar que suas características literárias e formais, extremamente enraizadas numa tradição cultural e numa visão de mundo bastante singular, exigem um olhar que se norteie sempre pela língua de partida. O significado dessa última afirmação ficará mais explícito nos parágrafos a seguir. É claro que existem outros caminhos possíveis para um trabalho como este, talvez igualmente válidos, mas prefiro caminhar o mínimo possível sobre a corda bamba que separa tradução de recriação. As escolhas que a tradução exige certamente far-me-ão colocar ao menos um dos pés sobre essa linha de 
vez em quando. De fato, ao se considerar as características de boa parte do meu corpus, a recriação se torna uma exigência, na prática, inevitável. Mas me parece mais lógico e inclusive ético (outra palavra-chave de muitos dos estudos sobre tradução hoje) fazer tais escolhas segundo os critérios do texto original.

A dicotomia estrangeirizador versus domesticador pode ser artificial, mas não creio haver escapatória do fato de que se está lidando com um texto estrangeiro, que deve ser tratado como tal na tradução. É o que diz Walter Benjamin, de forma admiravelmente sucinta, em seu A tarefa - renúncia do tradutor: "Por isso, o maior elogio a uma tradução, sobretudo na época de seu aparecimento, não é poder ser lida como um original em sua língua” (BENJAMIM, 2001, p. 209 - grifo meu). As incontáveis metáforas do rapto, do estupro e da violência sexual que às vezes permeiam a teoria da tradução vêm à cabeça para descrever esse grau de feiúra e truncamento que o texto traduzido às vezes comporta. Um dos capítulos de After Babel (STEINER, 1975) está tão cheio deles que, de brincadeira, alguém já propôs rebatizá-lo como “The pornemeutic motion" (o título original é, claro, The hermeneutic motion):

Comprehension, as its etymology shows, "comprehends" not only cognitively but by encirclement and ingestion. In the event of interlingual translation this manoeuvre of comprehension is explicitly invasive and exhaustive. Saint Jerome uses his famous image of meaning brought home captive by the translator (grifos meus).

Steiner se empolga (é difícil descrever sua atitude de outro jeito) e vai além: a tradução é descrita como "act of appropriative penetration". Com característico gosto pelo raciocínio etimológico, ele menciona "the appropriative 'rapture' of the translator - the word has in it, of course, the root and meaning of violent transport" (p. 300). Acho que não exagero ao dizer que essa visão do ato de traduzir é um veio explorado quase à exaustão - estamos perigosamente próximos de gastar o nosso estoque de metáforas. Mesmo assim, é difícil negar que uma certa violência (não necessariamente de natureza sexual) seja necessária à tradução: uma obra literária que, ao ser traduzida, pareça "certinha" demais, totalmente dentro do espectro de variação que existe no 
interior da língua-alvo, acaba virando uma simples belle-infidèle (aliás, mais uma metáfora sexual, e machista, ainda por cima. Espero que seja a última).

Chegamos agora ao meu ponto central, a razão mesma de ser deste trabalho: a necessidade de achar um eixo teórico fecundo para guiar a tradução da coletânea Tree and leaf, de J.R.R. Tolkien. Diante dessa obra, a importância de contemplar a especificidade de cada texto acima mencionada torna-se clara. Paradoxalmente, isso vem menos do fato de que cada um dos quatro textos do livro utiliza formas literárias bastante distintas - que vão do pentâmetro iâmbico mais tradicional ao conto, passando pelo ensaio e pela recuperação da rima aliterativa anglo-saxã - e mais da unidade estilística e de pensamento que caracteriza a literatura tolkieniana. Para começo de conversa, apesar da diversidade estilística, existe um diálogo claro de temas e forma entre cada um desses textos, microcosmo do diálogo maior que amarra, de ponta a ponta, toda a obra tolkieniana quando ela é examinada de um ponto de vista global. Um ponto jamais pode ser esquecido: estamos falando de um autor que é antes de tudo um filólogo. Ele nunca admitiu a separação, que considerava artificial, entre seu trabalho acadêmico e sua obra literária. O filólogo norueguês Helge Fauskanger, um dos maiores especialistas atuais nas línguas ficcionais desenvolvidas por Tolkien, ressalta que ele provavelmente se via como um "fillólogo criativo" (FAUSKANGER, 2004, p. 23).

Ora, isso significa que a obra tolkieniana não apenas se dedica a ressaltar a relação intrínseca entre língua e história que é o centro do trabalho filológico, mas também tenta utilizar isso como combustível criativo - como forma de influenciar o estilo, o léxico e a própria estrutura frasal, recuperando (mas também atualizando) momentos anteriores da língua inglesa. Mais ainda: para Tolkien, a tensão entre língua e história é mediada por um terceiro elemento: a "estória de fadas" ou mito, que ele considera ser uma conseqüência inevitável do fato de os seres humanos terem adquirido linguagem. As três coisas, na visão tolkieniana de mundo, estão emaranhadas de forma quase indistinguível e são, na verdade, elementos definidores do humano, como ele reitera de forma direta no ensaio On fairy-stories e no poema Mythopoeia e de forma alegórica no conto Leaf by Niggle.

Essa lista rápida de características talvez soe tão impenetrável quanto as genealogias hobbits que povoam os apêndices de $\mathbf{O}$ senhor dos anéis para o leitor nãofamiliarizado com o trabalho filológico. Foi preciso que alguém da mesma cepa profissional de Tolkien mostrasse em detalhe como essas coisas se entrelaçam. $\mathrm{O}$ trabalho coube ao britânico Tom Shippey, que lecionou boa parte do mesmo currículo 
que Tolkien ensinava na Universidade de Oxford e hoje é professor da Universidade Washington em Saint Louis (Estados Unidos). Em seu The road to Middle-earth (1982), Shippey consegue recuperar de maneira vívida o clima de excitação intelectual que acompanhava as descobertas da filologia comparada ao longo do século XIX, e o impacto dessa trajetória no trabalho do próprio Tolkien.

Esse retrato mostra que o elemento "criativo" da filologia esteve presente o tempo todo, ainda que os não-iniciados tivessem a impressão de que tudo se resumia a uma sucessão chatíssima de mutações consonantais e vocálicas na língua de um bando de bárbaros iletrados. As inferências que a presença de cognatos em línguas imensamente distantes no espaço e no tempo permitia ultrapassavam o universo lingüístico e abarcavam a história, a sociedade, a cultura. O inglês daughter, por exemplo, tem seu correspondente exato no sânscrito duhitar: tudo indica, no entanto, que a palavra em sânscrito originalmente tenha querido dizer "pequena ordenhadora" provavelmente porque as filhas recebiam essa tarefa na cultura indo-européia que falava o ancestral comum de ambas as línguas. "Comparison was the rage: it didn't tell you only about words, it told you about people" (p. 10), escreve Shippey. As possibilidades que uma simples comparação como essa trazem explicam por que os estudiosos tendiam a dar atenção especial para a trajetória temporal e as variantes sincrônicas de cada palavra individualmente, com todas as nuanças de forma e sentido que a palavra podia abrigar. Trata-se de um ponto importante, que retomaremos abaixo.

O processo podia ser extrapolado para um nível muito mais macroscópico, e foi o que aconteceu na imensa maioria dos casos: com a ajuda de comparações cada vez mais abrangentes e detalhadas entre línguas e dialetos, e de posse das "leis" de transformação fonética comuns às famílias lingüísticas (na verdade, tais leis quase certamente são conseqüências inevitáveis da estrutura física do aparelho fonador humano), os filólogos chegavam ao ponto de reconstruir com grau de detalhe impressionante idiomas que nunca haviam sido registrados. As várias versões de uma fábula no que seria o idioma indo-europeu comum (escritas por uma fieira de filólogos, todos envolvidos em debates calorosos e ainda em aberto sobre qual seria a melhor reconstrução; o texto, datado de 1868 e batizado originalmente de Avis akvasas ka, ou “A ovelha e os cavalos", já está na quarta versão) são o exemplo mais patente disso. Mas há outros: os pesquisadores pareciam viver no que Shippey chama de "realidadeasterisco". O nome é inspirado no fato de que as palavras não-registradas de uma língua que eram reconstruídas com base na filologia comparada eram marcadas com um 
asterisco na frente, como em *manniz, o suposto plural "homens" em germânico primitivo, o ancestral de todas as línguas germânicas, do gótico ao inglês. A crença na "realidade-asterisco" chegava a ser tamanha que, com base em simples características dialetais ou nomes de personagens, um estudioso podia chegar à conclusão de que um poema medieval preservado em, digamos, antigo alto-alemão (o caso do chamado Hildebrandslied) tinha sido originalmente composto (na forma oral, claro) em lombardo. E ir além da simples inferência, reescrevendo o poema inteiro na suposta forma original. Foi exatamente isso o que fez Willy Krogmann, da Universidade de Hamburgo. O fato de hoje o lombardo ser uma "língua-asterisco", que sobrevive apenas em alguns antropônimos, não parece tê-lo incomodado. O processo ia além dos poemas individuais e abrangia os próprios ciclos de lendas que os inspiravam. As pessoas tendem a esquecer que os irmãos alemães Jacob e Wilhelm Grimm, nomes que hoje são sinônimos de contos de fadas, empreenderam a coleta e registro dos contos populares alemães justamente como parte importante de seu trabalho como filólogos. Não é por acaso que o interesse de Tolkien pela origem e natureza dos contos de fadas (ou "estórias de fadas", como preferia dizer) tenha caminhado lado a lado com sua paixão filológica.

Como se vê, apesar do rigor fonológico, trata-se de um trabalho que comporta um grau bem maior de criatividade do que se imagina. Para Shippey, uma das afirmações mais controversas e mal-interpretadas de Tolkien - segundo a qual a invenção de línguas foi um dos fundamentos, aliás $o$ fundamento, de seu trabalho como escritor; as histórias foram criadas para dar às línguas um ambiente no qual podiam se desenvolver como uma coisa viva - deve ser entendida precisamente dentro desse contexto:

'Invention' of course comes from Latin invenire, 'to find'; its older sense, as Tolkien knew perfectly well, was 'discovery'. If one were to say of nineteenth-century philology that the discovery of languages was its foundation', one would be stating literal truth; as often, probably, Tolkien was playing with words, juxtaposing the languages he had made up out of his own head with those that others had found or 'reconstructed' all over the world, so aligning himself yet again with his professional inheritance (SHIPPEY, 1982, p. 22-23). 
Essa mesma paixão de natureza antiquária, ligada a uma tentativa deliberada de (re)construir um passado heróico ou, quando ele não existe, de montá-lo a partir dos ossos fragmentados da lenda e do mito, responde por boa parte do combustível criativo da literatura romântica e vitoriano-eduardiana. Tolkien era notoriamente refratário a reconhecer as influências da literatura inglesa moderna (moderna, bem-entendido, significa "posterior ao século XV" no dialeto tolkieniano) sobre o seu trabalho. Mas, tal como ocorre com a filologia comparada como um todo, intelectualmente ele devia muito ao Romantismo e a seus frutos mais tardios, justamente por causa dessa obsessão com a recriação do passado. Autores do fim do século XIX, como William Morris e seu romance The house of the Wolfings, na qual um passado mítico dos povos germânicos ganha o centro da cena, podem ser considerados precursores do que Tolkien tentaria realizar mais tarde. ${ }^{1}$

À primeira vista, parece um tanto difícil discernir essas características, ou no mínimo a inspiração que elas trazem, nos textos da coletânea. $\mathrm{O}$ olhar descuidado não encontra grande elaboração filológica na fachada de prosa acadêmica do ensaio On fairy-stories, que pode ser considerado com justiça o esteio do resto do livro. Essa faceta tampouco está muito aparente no estilo superficialmente frouxo e coloquial de Leaf by Niggle, ou nos pentâmetros iâmbicos de Mythopoeia (se há uma forma poética que não precisa de "reconstrução" filológica, em inglês ou em seu equivalente bastante próximo em português, o decassílabo, essa é certamente a melhor candidata). Apenas The homecoming of Beorhtnoth Beorhthelm's son, com sua utilização da métrica aliterativa anglo-saxã, parece ser a exceção à regra.

Pretendo argumentar, no entanto, que a perspectiva filológico-mítica (ou míticofilológica; eis outro caso clássico de ovo-e-galinha) é a chave para entender os quatro textos, para explicar por que Tolkien os escreveu como os escreveu - e, se posso me adiantar um pouco, para que eu tenha decidido traduzi-los da maneira como vou fazê-lo. On fairy-Stories e Mythopoeia, tão inseparáveis em forma e conteúdo que um trecho do segundo texto faz uma aparição especial no primeiro, estão prenhes da mesma preocupação com o que Tolkien chama de "sub-criação": como a linguagem e o mito recriam constantemente o mundo. $\mathrm{O}$ ensaio é particularmente interessante, desse ponto de vista, no uso parcimonioso mas crucial que faz, por exemplo, de palavras em sentido etimológico: worm não se refere a nenhum tipo de anelídeo, mas é mais a modernização

\footnotetext{
${ }^{1}$ Morris, tradutor das sagas e poemas islandeses, recuperou para o inglês moderno a mítica Mirkwood, a Floresta das Trevas, que depois figuraria em $\mathbf{O}$ hobbit e $\mathbf{O}$ senhor dos anéis.
} 
do inglês antigo wyrm - serpente e, em especial, dragão, a criatura mítica por excelência que povoava a imaginação infantil de Tolkien. A técnica é posta a serviço da ironia quando o autor se refere a um de seus colegas de Oxford como a clerk of Oxenford além do nome que a cidade tinha na época de Chaucer, a expressão pretende conjurar não a imagem de um atendente de loja, mas a dos prelados celibatários - clericus, clerk - que até o século XVIII eram os únicos autorizados a lecionar na instituição e em outros centros de ensino superior da Inglaterra.

Esse é o nível vocabular das idiossincrasias tolkienianas, manifestado também na escolha cuidadosa dos nomes dos personagens em Leaf by Niggle, por exemplo (mais detalhes poderão ser vistos na discussão específica desse texto, mais abaixo). Tom Shippey chama a atenção para tal cuidado lexical, considerado por ele como caracteristicamente filológico: os profissionais da área costumam extrair o máximo de cada vocábulo. Mas há também os traços que se manifestam no nível das frases e períodos: a sintaxe not quite normal, dada a inversões e truncamentos que a prosa moderna mais "elegante" desdenharia (e que um autor modernista provavelmente abominaria como prova de um passadismo completamente démodé), na pontuação idiossincrática e no uso abundante da conjunção and em passagens que evocam a King James Bible. Poucos escritores de hoje se sentiriam à vontade com uma construção como All manner of beasts and birds. Logo nos primeiros parágrafos de On fairystories, encontramos: "The realm of fairy-story is wide and deep and high and filled with many things" - para muita gente, um dos exemplos mais deploráveis do que um crítico classificou de "linguagem de cervejeiro bíblico", como quem diz que aquele arcaísmo é completamente falso (afirmação um tanto temerária de aplicar a alguém que passou a vida mergulhado no estudo das mais antigas manifestações literárias da língua inglesa; se alguém sabia o que era verdadeiro arcaísmo na Inglaterra do pós-guerra, esse alguém era J.R.R. Tolkien).

O desejo de reconstrução criativa que é a marca registrada do filólogo aparece claramente, como já dissemos, em The homecoming of Beorhtnoth Beorhthelm's son. A afirmação não se deve apenas à recuperação da métrica do inglês antigo mas também ao fato de que o próprio poema tolkieniano é, em certa medida, uma reconstrução ao estilo das fábulas em "indo-europeu”: a continuação do épico anglosaxão A batalha de Maldon, um fragmento sem começo e sem fim, que é completado 
de forma ao mesmo tempo arcaizante e moderna. ${ }^{2}$

Tolkien defendeu de forma veemente o direito de utilizar todos esses recursos na carta de número 171 da coletânea The letters of J.R.R. Tolkien, organizada por seu biógrafo, Humphrey Carpenter, e por seu filho mais novo e herdeiro literário, Christopher Tolkien. Eis o que ele disse a um leitor, o jovem Hugh Brogan, que criticou a suposta falsidade de seus arcaísmos (classificados de tushery pelo rapaz) em um trecho de $\mathbf{O}$ senhor dos anéis:

It was not what you said (last letter but one, not the one that I answered) or your right to say it, that might have called for a reply, if I had the time for it; but the pain that I always feel when anyone - in a age when almost all auctorial manhandling of English is permitted (especially if disruptive) in the name of art or "personal expression" - immediately dismisses out of court deliberate "archaism”. (...) But a real archaic English is far more terse than modern; also many of the things said could not be said in our slack and often frivolous idiom. Of course, not being specially well read in modern English, and far more familiar with works in the ancient and "middle" idioms, my own ear is to some extent affected; so that though I could easily recollect how a modern would put this or that, what comes easiest to mind or pen is not quite that. (...) Why deliberately ignore, refuse to see the wealth of English which gives us a choice of styles - without any possibility of unintelligibility.

(...) If mod. E. has lost the trick of putting a word desired to emphasize (for pictorial, emotional or logical reasons) into prominent first place, without the addition of a lot of little "empty" words (as the Chinese say), so much the worse for it. And so much the better for it the sooner it learns the trick again. And some $e^{3}$ one must begin the teaching, by example. (CARPENTER, 1995, p. 225-226)

\footnotetext{
${ }^{2}$ Um exemplo desse clash entre dois mundos no poema é sua estruturação dramática, com marcações de cena e trechos de métrica não-aliterativa. Mais detalhes serão dados no comentário dedicado especificamente a esse texto.
} 
É interessante notar que a disposição para seguir a idéia do último parágrafo e subverter a ordem tradicional de sujeito, verbo e objeto na frase em favor de outra mais "pictórica" e "emocional" é uma das marcas registradas de Tolkien em sua prosa ficcional e também em On fairy-stories; veja-se, por exemplo, o lapidar "To the elvish craft, Enchantment, Fantasy aspires, and when it is successful of all forms of human art most nearly approaches" - com os objetos indiretos ocupando posições completamente diferentes das que seriam esperadas.

Diante desses traços, parece particularmente fecundo abordar a presente tentativa de tradução a partir do ponto de vista de Berman (1985), com a mesma lente que esse teórico usou para enxergar as grandes traduções do Romantismo alemão. Berman parece particularmente preocupado em ressaltar a importância do estrangeiro no texto traduzido. "Translation is the 'trial of the foreign'. But in a double sense. In the first place, it establishes a relationship between the Self-Same and the Foreign by aiming to open up the foreign work to us in its utter foreigness", escreve ele em Translation and the trials of the foreign $(1985$, p.284). A expressão é tão importante para o autor que se tornou o título de seu livro sobre os tradutores românticos da Alemanha, A prova do estrangeiro. No mesmo ensaio, Berman chama a atenção também para o lado ético dessa proposta, já que, na imensa maioria dos casos ao longo da história, traduções e tradutores tenderam a fugir desse confronto com o Outro, o Estrangeiro, e reprimiram as tentativas de fazê-lo. "Hence, the necessity for reflection on the properly ethical aim of the translating act (receiving the Foreign as Foreign)". Trabalhos recentes sobre a ética da tradução fazem de Berman, por isso mesmo, uma espécie de padroeiro.

Em seguida, Berman traça um retrato dos diferentes tipos de "repressão do Estrangeiro", de polícia de imigração lingüística, que muitas traduções empreendem. Não creio ser necessário descrever em detalhe cada uma dessas violações, que são quase uma demonologia da tradução no enfoque bermaniano. Alguns comentários breves sobre esses pecados capitais, no entanto, podem ajudar a entender como Berman vê os problemas com os quais toda tradução se defronta. $O$ fato de ele enfocar especificamente obras em prosa também é especialmente útil para os textos que formam o coração da coletânea de Tolkien.

Dentro dos textos em prosa, Berman aponta os perigos da racionalização e da clarificação: os textos originais por vezes têm uma certa opacidade natural, que pode ser

\footnotetext{
${ }^{3} \mathrm{O}$ grifo é do próprio Tolkien (em itálico no original).
} 
resultado de uma pontuação parcimoniosa ou de uma estrutura frasal deliberadamente indefinida e elusiva, que o tradutor acaba por destruir em nome de uma elegância e uma fluidez artificiais. Parte-se do princípio de que o texto "bem escrito" não terá essas características, e que a tradução deve ser tão fluente quanto um texto originalmente escrito na língua de chegada - o que, com demasiada freqüência, acaba por torná-la mais fluente do que o próprio original. $\mathrm{O}$ fenômeno que Berman chama de expansão tem uma origem parecida: na busca por clareza, o tradutor não se importa em fazer crescer de forma desmedida a sua versão, afetando os padrões rítmicos que também são parte importante do texto em prosa (um problema que Berman classifica em separado, como "destruição de ritmos"). ${ }^{4}$

A mesma vontade de corrigir e melhorar o texto original na língua de chegada está presente no que Berman chama de enobrecimento. Nesse processo, a retórica e o beletrismo do idioma para o qual o texto está sendo traduzido acabam falando mais alto que as características mais rudes ou desviantes dele, que idealmente poderiam ser reproduzidas. Paradoxalmente, o próprio desejo de padronizar e embelezar a linguagem da tradução resulta em empobrecimento qualitativo e quantitativo, de acordo com Berman: os vários níveis de linguagem e dialeto que podem estar imbricados no texto original, graças à utilização de palavras divergentes da norma culta ou de uma cadeia de sinônimos ou termos relacionados acaba sendo borrada, fica esmaecida e apagada no texto traduzido.

Os parágrafos acima são suficientes para dar uma idéia da análise bermaniana, e acredito que fornecem ferramentas preciosas para o presente trabalho. É claro que nem todo o framework teórico do autor me parece consistente: é no mínimo duvidoso o papel que ele atribui aos psicanalistas na tentativa de libertar os tradutores das tendências que desrespeitam o texto original. Dizer que "these unconscious forces form part of the translator's being, determining the desire to translate" é claramente ir longe demais. Além de qualquer complexo psicanalítico, parece mais seguro e parcimonioso postular que hábitos culturais e literários muito arraigados, assim como a necessidade de ser palatável comercialmente, sejam mais importantes para criar as distorções que Berman aponta. É desnecessário dizer que a natureza da língua-alvo, inescapavelmente única e distinta da língua de partida, também desempenha um papel importante. Da mesma

\footnotetext{
${ }^{4} \mathrm{O}$ curioso nesse caso é que muitas passagens em prosa de Tolkien - mais raras em Tree and leaf, mas muito comuns, por exemplo, em $\mathbf{O}$ senhor dos anéis - têm estrutura rítmica quase indistinguível da de poesia metrificada. E não de qualquer poesia, mas exatamente da métrica aliterativa anglo-saxã.
} 
forma, o autor chega muito próximo de se transformar no inimigo que deseja combater ao afirmar, de forma um tanto ingênua, que a "clarificação" deve ser evitada, mas que o tradutor consciencioso pode ser capaz de manifestar o que está oculto ou "reprimido" (eis a mania psicanalítica de novo) no texto original. A pergunta óbvia que vem à cabeça diante da idéia é: who watches the watchmen? Em outras palavras, quem decide o que é manifestação clarividente do que já existia de forma oculta no original e o que é clarificação pedestre? Trata-se de um procedimento completamente ad hoc que me parece mais prudente evitar.

De qualquer maneira, creio que é seguro dizer que os elementos fornecidos por Berman ajudam a reconhecer que a fuga obsessiva de tudo o que possa ser estranho e estrangeiro não é suficiente para dar conta do texto tolkieniano - em especial porque, como argumentei acima, ele também parece, às vezes, ser estrangeiro na própria terra. Correndo o risco de parecer herético para quem não costuma incluir Tolkien no cânon (aliás, em qualquer cânon...) da literatura inglesa do século $\mathrm{XX}$, diria que existe um idioleto tolkieniano muito particular, assim como existe um idioleto de qualquer grande autor.

No entanto, e é aqui que imagino dar minha pequena contribuição a esse debate, creio que o texto tolkieniano pede um movimento duplo: reconhecimento do estrangeiro $e$ diálogo dele com o nativo (deixarei claro em breve o que quero dizer com essa proposta). E isso porque a força subjacente do pensamento filológico, que permeia o texto de Tolkien, chama a atenção para a trama comum das origens da língua e da mitologia - uma trama que, em se tratando de duas línguas da Europa Ocidental como o inglês e o português, está mais entrelaçada do que se costuma reconhecer. A imagem da gigantesca Árvore das Estórias proposta por Tolkien, com seus galhos que se estendem e se ramificam para todos os lados desde a origem da linguagem humana, representa isso de forma clara. (Peço paciência ao leitor: quando as traduções forem apresentadas, a última alusão há de ficar mais clara.) O filólogo alemão Max Müller (1823-1900) declarou certa vez que a mitologia era "uma doença da língua"; em On-fairy stories, Tolkien rebate: "Estaria mais perto da verdade dizer que as línguas, em especial as línguas européias modernas, são uma doença da mitologia”.

Levando a analogia epidemiológica até as últimas conseqüências, parece legítimo dizer que povos e culturas se reinfectam continuamente com essa bactéria; as cepas do patógeno circulam em todos os sentidos, do Oriente ao Ocidente, e vice-versa. Peço mais uma vez a indulgência do leitor por adicionar um detalhe que, para mim, 
como jornalista de ciência, é irresistível: desde o advento da biologia molecular, sabe-se que as "espécies" de bactéria que conhecemos são pouco mais que uma ilusão taxonômica, por obra e graça de um fenômeno conhecido como transferência horizontal. $\mathrm{Na}$ prática, isso significa que bactérias de uma espécie podem trocar material genético, mais ou menos livremente, com os membros de qualquer outra espécie bacteriana (e às vezes até não-bacteriana). Quero crer que assim é no universo que estamos abordando: não há material genético mais promíscuo do que o DNA mítico (e lingüístico).

Walter Benjamin chegou a sugerir uma versão dessa proximidade fundamental entre as línguas quando afirma, em A tarefa - renúncia do tradutor, que a tradução mais bem-sucedida é a que consegue revelar o que há de comum, em termos quase místicos, entre um idioma e outro. Por fascinante que a idéia seja, é difícil ir tão longe. Por um lado, hoje há muito menos margem de discussão para o fato de que as barreiras lingüísticas são, em última instância, superficiais (detratores de Chomsky à parte). A neurociência e o estudo de fenômenos como as línguas crioulas têm mostrado que a estrutura mental humana está "pré-adaptada" ao uso de um idioma falado desde o nascimento. Seres humanos com deficiências mentais ou lesões cerebrais sérias são, mesmo assim, capazes de utilizar a linguagem com máxima competência, sem esforço algum, e o reverso também é verdadeiro: pessoas de inteligência completamente normal sob outros aspectos tropeçam flagrantemente em suas tentativas de utilizar corretamente rudimentos de gramática por causa de deficiências genéticas simples - indícios fortes de que o potencial para a linguagem é um "módulo" independente e em grande medida inato da inteligência humana. Crianças cujos pais se comunicavam num pidgin completamente agramatical e ad hoc conseguiram, no espaço de uma geração, recriar sozinhas um idioma tão dotado de recursos gramaticais e sintáticos quanto uma língua com milênios de história; no caso das crianças surdas-mudas que são as grandes responsáveis pelo surgimento de línguas de sinais coerentes em todos os cantos do planeta, nem a articulação vocal foi necessária para que um sistema de flexões verbais surpreendemente análogo ao de uma língua oral surgisse (para uma revisão bastante atualizada de todas essas questões, ver PINKER, 2002).

No entanto, apesar dessa unidade fundamental do fenômeno lingüístico, pode-se argumentar que a multiplicidade de formas que as línguas do mundo real assumem acaba, na prática, por impedir o sonho de Benjamin na maioria dos casos. De qualquer maneira, argumentaria esse cético, as barreiras de hábitos lingüísticos, de sintaxe, fonética, sinonímia e tantos outros elementos que dividem idioma de idioma não se 
tornaram menos reais graças à descoberta de pontos comuns e inatos nos fenômenos lingüísticos. Mas, para nossa sorte, o inglês e o português, como já mencionei, nasceram e cresceram dentro desse microambiente maravilhosamente promíscuo das línguas européias, filhas do indo-europeu e afilhadas do grego e do latim. A própria história da língua inglesa, originalmente de matriz germânica mas infundida de doses generosas de "genes" do tronco latino, principalmente pela via do francês, é um convite claríssimo a esse tipo de empreendimento. ${ }^{5}$ Seria no mínimo um desperdício não se aproveitar desse fato para que, por meio da tradução, o estrangeiro seja revelado através do que parece nativo.

Para começar com alguns exemplos (muitos outros deverão ficar patentes na tradução em si), poucas palavras são mais típicas da tradição das estórias de fadas inglesas do que Faërie, a Terra das Fadas. Ou será que não? A Árvore das Estórias (que também é a das línguas) lançou dois ramos franceses para lados distintos: um deles gerou fay, fairy em inglês por volta do século XIV, e o outro, quatrocentos anos depois, produziu feérico em português. É por isso que eu proponho Feéria para traduzir o termo tolkieniano. A proposta tem a vantagem de reproduzir inclusive o hiato implicado pela forma tolkieniana Faërie (com trema, N.B.). Duas outras palavras-chaves de On fairystories, counterfeit e stuff, podem ser traduzidas com conservação de significante quase perfeita por meio de "contrafação" e "estofo". Há, sem dúvida, certo estranhamento, um deslocamento de sentido e de hábitos lingüísticos - muito mais natural seria usar "falsidade" e "matéria-prima" -, mas é justamente essa sacudidela semântica e formal que a tradução consegue realizar. Essa resistência ao descolamento de significante e significado também está no coração do pensamento filológico.

É claro que esse método não funciona o tempo todo. Por vezes, não há equivalentes à mão, sem falar na complexidade adicional de lidar com essas questões no nível sintático, frasal. Um dos momentos mais frustrante é o jogo de palavras etimológico que Tolkien faz com as palavras fancy e fantasy - originalmente a mesma palavra que tomou rumos diferentes. Essa trajetória extremamente específica, fruto em grande parte do acaso e da deriva lingüística, simplesmente não aconteceu em português. Idiomas são entidades históricas por definição, e esse tipo de aporia ajuda a recordar que em nenhum par de línguas do mundo se encontram histórias de

\footnotetext{
${ }^{5}$ É bom lembrar que, ainda que numa escala muito menor, o impacto do francês se fez sentir no português em muitas das mesmas áreas em que essa língua "colonizou" o inglês - o campo da cultura e o das artes, por exemplo.
} 
desenvolvimento exatamente iguais. Voltando à analogia com a biologia evolutiva, é impossível fazer um golfinho nadar abanando a cauda lateralmente: a anatomia de seus membros posteriores, porquanto oculta sob o que parece ser uma barbatana, ainda é a dos seus ancestrais terrestres - e eles andavam erguendo e abaixando as patas, verticalmente, tal como ainda nadam seus descendentes aquáticos. Assim é também com os idiomas e as palavras. Em casos como esses, é forçoso reconhecer que o sistema de equivalências sobre o qual repousa a idéia da tradução se esgarça, e parece difícil pensar em solução melhor do que simplesmente utilizar os termos na língua original.

Há também a difícil tarefa de discernir entre o que é mero cacoete do inglês, uma forma fixa lingüística que há muito perdeu qualquer expressividade própria, e o que deve ser reproduzido às custas de uma suposta elegância do texto traduzido. A utilização da voz passiva analítica nos momentos mais científicos e acadêmicos de On fairy-stories é, na minha opinião, o exemplo mais claro disso: "Even Peter the Rabbit was forbidden a garden"; "the story is found to be widespread". Qual é o grau de expressividade pessoal desse tipo de construção? Nenhum, parece ser a resposta mais lógica, mas poucos casos são tão pouco controversos. (Na maioria dos casos, a regra de ouro de Benjamin, penso eu, continua a valer: se o tempo todo o texto parece ter sido escrito na língua-alvo, há alguma coisa errada.)

De qualquer maneira, parece-me que a argumentação de Berman tem valor duplo: se a função da tradução é "to reveal the foreign work's most original kernel, its most deeply buried, most self-same, but equally the most distant from itself', também é verdade que o texto original consegue revelar o estrangeiro que se esconde na língua de chegada - se tivermos olhos para ver. Nesse sentido, as especulações quase teológicas de Benjamim sobre a possibilidade de refazer a unidade lingüística perdida no desastre de Babel encontram um paralelo surpreendente nos textos tolkienianos que integram Tree and leaf. O corolário de On fairy-stories, Leaf by Niggle e Mythopoeia é que a sub-criação, o pendor pela fantasia que é a marca do humano e cuja manifestação por excelência é a compulsão por contar histórias, brota diretamente da natureza do homem como ser criado. O católico Tolkien encontra, nesse postulado teológico, uma forma de consagrar o próprio trabalho literário a Deus e de santificá-lo. Uma palavra ronda esse raciocínio e, embora nunca seja mencionada, está sempre presente. É um termo grego: Lôgos, o Verbo divino, a mesma Palavra que o "marxista rabínico" ${ }^{6}$ Benjamim via, tal

\footnotetext{
${ }^{6}$ Empresto a expressão do ensaio de Kampff Lages (1998, p. 81) sobre A tarefa - renúncia do tradutor.
} 
como fazia a tradição judaica que o precedeu e inspirou, como o instrumento de Deus para a criação do mundo. Não é por acaso que Tolkien vê o Evangelho como a estória de fadas por excelência: é nela que o Lôgos adentra a realidade na forma do homem Jesus Cristo, é nela que a sub-criação ganha o status de criação verdadeira. Irrealizável na esfera limitada da história humana, a unidade das línguas e das estórias é possível nessa dimensão, argumenta Tolkien. Pode-se discordar de tal visão, mas a força mítica da qual ela brota é inegável. 


\section{J.R.R. Tolkien: breve nota biográfica}

John Ronald Reuel Tolkien nasceu em Bloemfontein, no Estado Livre de Orange (hoje parte da África do Sul), no dia 3 de janeiro de 1892. Seu pai, Arthur Tolkien, descendia de uma família de imigrantes alemães da Saxônia (cujo nome original provavelmente era Tollkühn), estabelecida na Inglaterra desde o fim do século XVIII, como fabricante de pianos. Tanto Arthur quanto a futura mãe de Tolkien, Mabel Suffield, eram naturais de Birmingham, onde ficaram noivos. Bancário de profissão, Arthur foi contratado pelo Bank of Africa e por isso se casou com Mabel em Bloemfontein, onde também nasceu o segundo e último filho do casal, Hilary. A intenção do pai do autor provavelmente era permanecer no continente africano. No entanto, a saúde de Mabel e dos meninos levouos a passar uma temporada na Inglaterra, enquanto o pai ficava na África. Arthur, então, contraiu febre reumática e acabou morrendo em 1896.

Por algum tempo, Mabel conseguiu sobreviver com a ajuda dos parentes. Mãe e filhos passariam quatro anos relativamente tranqüilos no hamlet de Sarehole, a poucas milhas de Birmingham. A paisagem rural do lugar, com seus camponeses que falavam no dialeto das Midlands, o moinho e as árvores antigas, marcaria profundamente Tolkien, que acabaria se inspirando nessas características ao criar o Condado onde habitam os hobbits de $\mathbf{O}$ senhor dos anéis.

A situação, no entanto, complicou-se em 1900, quando Mabel decidiu converterse ao catolicismo. Tanto o lado Tolkien quanto o lado Suffield de sua família não aprovaram a decisão, e a viúva perdeu grande parte da ajuda dos parentes. Para que os meninos pudessem estudar, Mabel voltou para Birmingham. Na cidade, a ajuda do padre Francis Morgan, membro de um oratório local, impediu que sua situação financeira piorasse ainda mais. Tolkien foi matriculado na King Edward's School, instituição onde seu irmão também estudaria mais tarde e que lhe proporcionou forte formação clássica. Traduzia com facilidade versos ingleses para o latim e o grego e, com o incentivo de alguns professores, começou a descobrir o anglo-saxão ou inglês antigo, bem como o médio inglês de Chaucer. Entrementes, Mabel descobriu que tinha diabetes. Sem tratamento na época, a doença acabaria por levá-la à morte em 1904.

No testamento, ela legou ao padre Morgan a responsabilidade pela criação dos filhos. Depois de uma breve temporada na casa de uma tia, eles se mudaram para uma pensão onde vivia outra jovem órfã, Edith Bratt, três anos mais velha que John Ronald. Os dois começaram a namorar às escondidas, mas o romance foi interrompido pelo 
padre Morgan - ele acreditava que a educação do rapaz ficaria prejudicada. Os dois concordaram em não se ver até os 21 anos, quando Tolkien alcançaria a maioridade.

Em dezembro de 1910, ele obteve uma bolsa de estudos do Exeter College, na Universidade de Oxford, e tornou-se aluno do curso de literatura clássica. Contudo, desinteressou-se da área e passou a gastar muito mais tempo com estudos de filologia, sob orientação de Joseph Wright, um dos principais pesquisadores britânicos da área na época e dono de um conhecimento enciclopédico sobre o tronco lingüístico indoeuropeu. Descobriu o gótico, o galês e o finlandês, todos idiomas que teriam profunda influência sobre sua criação lingüística - nessa época, já esboçava algumas das línguas ficcionais que teriam papel importante no universo da Terra-média. ${ }^{7}$ Acabou decidindo transferir-se para a Honour School of English Language and Literature, na qual seu desempenho acadêmico melhorou substancialmente, impulsionado por seu interesse pela filologia germânica. Em 1913, reencontrou-se com Edith, com quem formalizou o noivado no ano seguinte.

Com o rompimento da Primeira Guerra Mundial, alistou-se no Exército britânico e casou-se pouco antes de partir para a França, em 1916, como segundo-tenente do $11^{\mathrm{o}}$ Corpo de Fuzileiros de Lancashire. Na batalha do Somme, serviu durante três meses como oficial sinalizador, até contrair febre das trincheiras (doença transmitida por piolhos) e voltar convalescente à Inglaterra. Enquanto se recuperava, deu início a The book of lost tales, primeiro esboço da mitologia dos Dias Antigos da Terra-média que depois tornar-se-ia O Silmarillion.

Depois de um período breve mas intelectualmente muito rico como membro da equipe que concluía o Oxford English dictionary, Tolkien foi aceito como professor do Departamento de Inglês da Universidade de Leeds, para onde se mudou em 1920. Na cidade nasceram seu segundo e terceiro filhos, Michael e Christopher (ele e Edith já tinham John, e ainda teriam uma menina, Priscilla). No norte da Inglaterra, ele conseguiu implantar com sucesso uma reforma acadêmica que unia de forma inteligente os estudos filológicos e os literários no período que ia do anglo-saxão a Chaucer. Em 1925, no entanto, ele foi eleito para a Cátedra Rawlinson e Bosworth de Anglo-Saxão em Oxford, onde passaria o resto de sua vida profissional.

Como brinca o principal biógrafo do autor, Humphrey Carpenter, poderíamos dizer que, daí em diante, praticamente mais nada aconteceu: Tolkien lecionou até 1959,

\footnotetext{
${ }^{7}$ De fato, os dois idiomas élficos que mais estão próximos da completude são o quenya, com fortes influências do finlandês, do latim e do grego; e o sindarin, cuja principal inspiração é o galês.
} 
quando aposentou-se e foi para Bournemouth; perdeu Edith em 1971 e morreu de maneira tranqüila em 1973. Acontece que esses anos sem grandes acontecimentos marcaram seu amadurecimento como escritor, em parte graças à amizade com C.S. Lewis, de quem se tornou colega em 1926 e com quem fundou as confrarias literárias informais conhecidas como Coalbiters e Inklings. Ao mesmo tempo em que refinava a "mitologia para a Inglaterra" que começou como Lost tales e terminou como $\mathbf{O}$ Silmarillion, Tolkien divertia-se em criar histórias para os filhos, uma das quais era o embrião de $\mathbf{O}$ hobbit. Essa história foi "temperada" com alguns elementos mais sombrios e sérios da mitologia que ele estava desenvolvendo, mas ainda era marcadamente infantil. Mesmo assim, amigos do autor a mencionaram para o dono da editora Allen \& Unwin, que resolveu apostar no texto e publicá-lo em 1937.

O sucesso de público e crítica foi imediato, o que levou Stanley Unwin, proprietário da editora, a pedir-lhe uma continuação. O que o autor realmente desejava era a publicação de $\mathbf{O}$ Silmarillion mas, como o texto (em estado muito desorganizado) foi rejeitado polidamente pela Allen \& Unwin, Tolkien pôs-se a trabalhar no que passou a chamar de "o novo Hobbit". Inconsciente ou conscientemente, porém, ele perdeu o controle da história: retomando o motivo do Anel encontrado pelo hobbit Bilbo no livro original, a trama adquiriu tons muito mais sombrios e tornou-se, para todos os efeitos, uma conclusão de $\mathbf{O}$ Silmarillion. Era $\mathbf{O}$ senhor dos anéis.

Tolkien criara um monstro: o texto só foi concluído doze anos depois dos primeiros rascunhos, mas recebeu elogios de Rayner Unwin, o filho de Stanley, que havia resenhado $\mathbf{O}$ hobbit para seu pai quando criança e agora, já adulto, recomendava a publicação do novo livro. O problema é que Tolkien havia condicionado esse fato à publicação conjunta com O Silmarillion, pelo qual outra editora, a Collins, havia manifestado interesse. No fim das contas, as negociações malograram, e Tolkien aceitou publicar apenas $\mathbf{O}$ senhor dos anéis, dividido em três volumes para evitar um preço muito alto, pela Allen \& Unwin. O primeiro deles, A sociedade do Anel, chegou às livrarias em 1954.

O sucesso foi imediato em ambos os lados do Atlântico, apesar dos ataques de boa parcela da crítica, mas os livros só alcançaram o status de cult nos anos 1960, quando uma edição pirata norte-americana tornou-se mania entre os estudantes universitários dos Estados Unidos. Tolkien ganhou renome mundial, situação que, na verdade, era bastante incômoda: visitantes excêntricos surgiam do nada, fãs americanos 
ligavam no meio da madrugada sem se lembrar do fuso horário. Essa atenção indesejada foi um dos motivos que o levaram a se mudar para Bournemouth.

Por ordem expressa do autor, a lápide do túmulo que ele divide com a esposa Edith faz referência direta a seu universo ficcional: nela, eles são chamados de Beren e Lúthien - o casal formado por um humano e uma elfa cuja história de amor é o elemento mais importante de $\mathbf{O}$ Silmarillion e, pode-se argumentar, de todo o legendarium tolkieniano. 


\section{A Rima Aliterativa Anglo-Saxã}

Seria redundante ou até mesmo ofensivo à inteligência do leitor incluir neste trabalho uma discussão sobre a maior parte dos gêneros literários e formas fixas poéticas utilizadas por Tolkien em Tree and leaf. O ensaio, o conto e os pentâmetros iâmbicos são de tal forma "canônicos" para o leitor familiarizado com a literatura ocidental dos últimos 500 anos que dispensam apresentação. No entanto, esse certamente não é o caso da rima aliterativa anglo-saxã que o autor utiliza no poema dramático The homecoming of Beorhtnoth Beorhthelm's son. Embora outros autores do século XX a tenham recuperado (os exemplos mais célebres incluem Ezra Pound e W.H. Auden), sua utilização não deixa de ser uma marca registrada da poesia tolkieniana (ela reaparecerá, por exemplo, em situações-chave de $\mathbf{O}$ senhor dos anéis, interrompendo a narrativa em prosa, como uma forma poética utilizada tradicionalmente pelos cavaleiros de Rohan), e poucos escritores modernos tinham tanta familiaridade com ela. Por causa de suas características formais singulares, as quais, na minha opinião, é preciso conhecer para uma apreciação acurada da presente proposta de tradução, julguei conveniente incluir aqui uma apresentação sucinta de suas principais características. As informações contidas aqui foram retiradas de uma variedade de fontes, que podem ser encontradas na bibliografia. As principais obras de referência foram The monsters \& the critics and other essays (TOLKIEN, 1997), The Cambridge companion to Old English literature (GODDEN e LAPIDGE, 1991) e A guide to Old English (MITCHELL e ROBINSON, 1992).

O que se deve dizer em primeiro lugar a respeito dessa forma poética é que tanto os termos "rima" quanto "anglo-saxã" são apenas parcialmente corretos quando aplicados a ela. (Mesmo o termo "aliterativa" tem seus críticos, entre eles o próprio Tolkien. Ele lembra que o que importa não são as "letras", mas os fonemas. Detalharemos essa questão em breve.) Como veremos, a rima, da maneira como é utilizada em grande parte da poesia européia pré-Modernismo, não tinha presença obrigatória nem função de destaque $^{8}$ na poesia praticada pelos povos germânicos antigos. Isso inclui tanto a Inglaterra saxônica pagã e cristã (do fim do século V a 1066) quanto a Escandinávia e a Islândia, bem como as regiões menos romanizadas da

\footnotetext{
${ }^{8}$ Em alguns casos é possível, sim, encontrar o que aprendemos a chamar de rima no final dos versos. No entanto, seu efeito auditivo é considerado, nessa métrica, um ornamento ocasional, oriundo da expressividade do poeta naquele contexto, e não um parâmetro obrigatório.
} 
Alemanha. A métrica aliterativa parece ter feito parte do patrimônio literário comum desses povos até os séculos XI e XII, quando a influência da Europa latina (no caso inglês, graças ao francês e ao normando), implantou o predomínio da rima. A Inglaterra conheceu uma breve "Renascença aliterativa" no século XIV, representada principalmente pelo autor anônimo de Sir Gawain and the Green Knight, Pearl e Sir Orfeo, mas o que se vê então é uma forma híbrida, na qual muitas estrofes se encerram com quartetos com rima A-B-A-B.

\subsection{Unidade: a meia-linha}

Deixando de lado esses desenvolvimentos posteriores, como é possível descrever a métrica aliterativa "clássica" da Inglaterra saxã, durante o apogeu da tradição épica que produziu Beowulf e A batalha de Maldon (esse último a inspiração direta de Tolkien para The homecoming of Beorhtnoth Beorhthelm's son)? A primeira coisa a notar é que a "unidade mínima" desse tipo de poema, se é que podemos empregar esse termo, não é o verso, mas o meio-verso ou meia-linha, que está separado do outro por uma cesura ou pausa (utilizarei ambas as expressões indiferentemente aqui, com predomínio de “meia-linha”). ${ }^{9}$ Falando do próprio Beowulf, Tolkien o compara ao trabalho de um construtor, de alguém que trabalha com rocha, e não ao do músico que às vezes é entrevisto nos versos rimados: é como se cada meio-verso fosse um dos dois pilares que mantêm uma viga de pé.

Paradoxalmente, não é possível apontar um número exato para os "blocos" de concreto que formam esses pilares: existe um mínimo de quatro sílabas para cada meialinha, mas essa cifra pode variar dependendo principalmente da quantidade de sílabas tônicas e átonas que compõem a unidade (mais sobre isso abaixo). Em "peso" tônico e métrico, as quantidades de ambos os tipos de sílaba devem ser mais ou menos equivalentes. Os elementos tônicos são geralmente apelidados de lifts; os átonos recebem o nome de dips. Além disso, há um elemento intermediário, a chamada tônica secundária (secondary stress). Há o costume de se atribuir um valor numérico padrão para cada um desses elementos: assim, uma tônica "verdadeira" vale 4 ou 3, uma

\footnotetext{
${ }^{9} \mathrm{O}$ termo "hemistíquio", originário da poesia greco-latina, também poderia ser empregado aqui. Originalmente, ambas as tradições têm algo em comum, como, por exemplo, a importância da quantidade silábica (ou seja, a presença de sílabas longas e breves) para a escansão. No entanto, como a tradição aliterativa se desenvolveu sem influência direta dos modelos clássicos, preferi o neologismo sem o sabor classicista que "hemistíquio" comporta.
} 
secundária 2 ou 3 e uma átona 1, o que dá o valor médio de 10 para cada meia-linha. É bom lembrar que a atribuição desses valores tenta seguir ao máximo os padrões de tonicidade e ênfase da fala normal em anglo-saxão (e em inglês moderno).

\subsection{Meias-linhas canônicas}

O mais importante, no entanto, é que o poeta deve necessariamente trabalhar com seis variantes "canônicas" das meias-linhas. As meias-linhas são "amarradas" entre si pelo uso da aliteração, e é esse fato, ao lado da utilização correta das variantes, que define se um verso é métrico ou não. Há um grau de variabilidade e inexatidão inerente a esse sistema, ao contrário da rigidez (em termos de número permitido de sílabas, por exemplo) que se encontra na poesia de matriz clássica em língua portuguesa. Abaixo, apresento as formas mais simples e esquemáticas dessas variantes obrigatórias. $\mathrm{Na}$ notação utilizada, o acento agudo corresponde às tônicas principais, o grave indica as tônicas secundárias e as sílabas átonas não estão acentuadas. ${ }^{10}$

Tipo A: Caindo-caindo - Ánna ángry

Tipo B: Subindo-subindo - And Béorhtnoth bóld

Tipo C: Em confronto - In kéen cónflict

Tipo Da: Caindo por estágios - Díng dówn stròngly

Tipo Db: Queda quebrada - Déal déath to àll

Tipo E: Cai e sobe - Éach òne with édge

Ora, o leitor familiarizado com o sistema métrico canônico da poesia inglesa após a invasão normanda, o chamado acentual-silábico, poderia se perguntar o que torna uma meia-linha do tipo A diferente de um troqueu, ou o que distingue o tipo B de um iambo. Acontece que, como já foi dito, o número mínimo de quatro sílabas por meialinha pode ser ultrapassado, em especial no caso das átonas no interior da meia-linha (no caso dos tipos A e D) e no começo dela (situação comum nos tipos B e C). Assim, após a primeira tônica no tipo A, até quatro sílabas átonas podem aparecer antes que uma nova sílaba tônica, seguida de outra átona, defina que se trata realmente de um meio-verso A. O mesmo ocorre com todos os outros tipos de meia-linha. Assim, de

\footnotetext{
${ }^{10}$ A ordem das letras, de A a E, não é casual. Ela foi estabelecida em ordem decrescente de ocorrência, de modo que o tipo A é o mais comum e o E, o mais raro.
} 
forma esquemática, eis as formas "máximas" que esses componentes podem assumir. $\mathrm{Na}$ notação utilizada, o "a" corresponde às sílabas átonas, enquanto as letras entre parênteses indicam que até aquele número de sílabas átonas pode ocorrer somado ao número mínimo requerido. $\mathrm{O}$ "t" sinaliza as tônicas e o "s", as subtônicas:

\author{
Tipo A: $\mathbf{t}$ a (a a a a) $\mathrm{t}$ a \\ Tipo B: (a a a a) a $\mathbf{t}$ a (a) $\mathbf{t}$ \\ Tipo C: (a a a a a) a $\mathbf{t} \mathbf{t}$ a
}

Tipo Da: $t$ (a a a) $\mathrm{t} s$ a

Tipo Db: $t$ (a a a) t a s

Tipo E: t s a (a) t

Quando essas opções são levadas em consideração e utilizadas pelo poeta, a variabilidade dos seis tipos canônicos é muito maior do que a existente no ritmo iâmbico ou trocaico, mesmo com a utilização de substituições por anapestos, dáctilos ou outros tipos de pé em parte do verso, como é comum na poesia clássica inglesa.

Como acontece na métrica acentual-silábica tradicional, é a vizinhança imediata de uma palavra no meio-verso que vai determinar se ela possui uma tônica ou não. Substantivos e adjetivos tendem a carregar as tônicas principais em qualquer meia-linha, seguidos, conforme a necessidade, por verbos no infinitivo ou no gerúndio, advérbios e verbos conjugados - pronomes, artigos, conjunções etc. quase sempre são átonos, embora o contexto possa, com freqüência, levar a variações nessa regra geral. Em inglês e anglo-saxão, as palavras compostas é que costumam abrigar o maior número de tônicas secundárias (na sílaba tônica do secundo elemento da palavra composta, como, por exemplo, hígh-crèsted hélms, uma meia-linha do tipo E). Dependendo do caso (como nos tipos A, B e C), essas tônicas secundárias dos compostos também podem se tornar um dos lifts de uma meia-linha. É o caso de váliant-tìmbered (A), those séafàrers $(\mathrm{C})$ e that their séa-pàssage (também $\mathrm{C}$ ).

Embora os lifts tendam a ser monossilábicos, é possível "quebrar" um lift em duas sílabas numa palavra que contenha uma sílaba tônica curta e outra átona: assim, véssel e méllow são equivalentes métricos de boat e ripe. Por outro lado, é possível utilizar padrões que ultrapassem ligeiramente o peso métrico ideal: são os procedimentos de "sobrepeso" (overweighting) e extensão (extension). O primeiro, mais freqüente no tipo A, consiste em substituir um dos dips por uma tônica secundária. É o 
caso de bráve mèn blíthely ou wéllmàde wárgèar (sobrepeso duplo!). A extensão, mais comum nos tipos $\mathrm{Da}$ e $\mathrm{Db}$, consiste em adicionar uma sílaba átona ao primeiro lift normalmente monossilábico dessas meias-linhas: exemplos são árdent árchàngels $\mathrm{e}$ bóld and brázenfàced (o normal seria algo como bríght árchàngels e bóld brázenfàced). Esses padrões, considerados pesados e excessivos, normalmente têm sua utilização restrita à primeira meia-linha de um verso. Além disso, para aliviar seu peso, eles recebem aliteração dupla, como veremos a seguir. Finalmente, é possível começar um verso com uma anacruse (em geral um dip monossilábico ou dissilábico, muito raramente trissilábico), de maneira a resolver alguma necessidade semântica urgente que a concisão que as meias-linhas exigem talvez restrinja.

À primeira vista, a quantidade de regras, variantes e exceções pode parecer tão vasta que a impressão que fica é a de um jogo sem regras. Na verdade, é exatamente o contrário: essa elaboração, somada ao fator crucial da aliteração, estabelece de forma bastante clara o que é métrico e o que não é, constituindo um desafio formidável para o poeta.

\subsection{Aliteração}

O fato de os meios-versos serem unidades semi-independentes explica uma das características da rima aliterativa que, para os ouvidos modernos, é provavelmente uma das mais estranhas: a aliteração "dominante" é a da segunda meia-linha, e é ela que vai influenciar o restante do verso. O fonema dominante em questão é o da primeira tônica ou lift da segunda meia-linha. Nesse meio-verso, ele é o único a aliterar; na primeira meia-linha, tanto um dos lifts quanto ambos podem aliterar, e em alguns casos os dois têm de fazê-lo para alivar o "excesso de peso" do conjunto, como explicado acima. Mesmo se esse excesso não estiver presente, o poeta pode empregar aliteração dupla na primeira linha por razões expressivas ou decorativas - mesmo a aliteração cruzada ${ }^{11}$ às vezes ocorre, com esse tipo de propósito ornamental ou de virtuosismo. Normalmente, o primeiro lift da primeira meia-linha, por ser semântica e sintaticamente mais forte, carrega a aliteração, mas pode haver variações, especialmente nos tipos A e B. As vogais sempre aliteram com quaisquer outras vogais; quanto às consoantes que iniciam uma palavra, o anglo-saxão tem casos especiais (os encontros $s t$, $s p$ e $s c$ ) que são

\footnotetext{
${ }^{11}$ Nesse caso, o primeiro lift de uma meia-linha alitera com o primeiro da outra, e o segundo da primeira alitera com o segundo da outra.
} 
considerados "ditongos consonantais", ou seja, só aliteram entre si. Em português, obviamente, $x$ alitera com $c h$, e o dígrafo $q u$ seguido de $e$ e $i$ alitera com $c a, c o$ etc. Em todo caso, a função principal do procedimento é sempre dar unidade aos padrões dos vários tipos que se justapõem para formar os versos.

Abaixo, temos alguns exemplos retirados do próprio original de The homecoming of Beorhtnoth Beorhthelm's son, com os tipos indicados ao lado de cada meio-verso e a aliteração marcada com consoantes em negrito:

E Here! Lend a hand! This head we know! B

B O lord beloved, where do you lie tonight B

C Was like words whispered by waking ghosts B

Com variantes mais complexas, um trecho de Beowulf no original anglosaxão: ${ }^{12}$

$\mathrm{Db}+$ fyrst forð gewát. Flota wæs on ýðum A

A bát under beorge. Beornas gearwe $\mathrm{A}$

C on stefn stigon. Stréamas wundon A

A sund wið sande. Secgas bǽron A

$\mathrm{C}$ on bearm nacan beorhte frætwe $\mathrm{A}$

$\mathrm{A}+$ gúðsearo geatolic. Guman út scufon $\mathrm{Da}$

$\mathrm{A}+$ weras on wil-síð wudu bundenne $\mathrm{Da}$

A gewát ${ }^{13}$ ða ofer wǽg-holm, winde gefýsed A

$\mathrm{Db}$ flota fámig-heals fugle gelícost $\mathrm{A}^{14}$

Como se vê, é um tipo de poesia e linguagem a qual, embora possa nos parecer superficialmente "homérica", tem uma dicção e uma estrutura próprias, centrada nos paralelismos, na força das construções e das imagens justapostas. De especial importância são os chamados kennings (do islandês “comparação"), um tipo

\footnotetext{
${ }^{12}$ As vogais e os ditongos longos estão marcados com acento agudo, e as aliterações com negrito. Os meios-versos onde aparece o sinal de + são os que contêm padrões com "excesso de peso".

${ }_{13}^{13}$ É interessante notar a presença da anacruse - o prefixo átono ge, comum para verbos no passado.

${ }^{14}$ Uma tradução livre desses versos: "O tempo passou. A barca estava nas ondas/ navio sob o penhasco. Guerreiros ávidos/ na proa andavam. Marolas rolavam/ mar contra a areia. Os varões levaram/ para as entranhas da nave os brilhantes petrechos/ armas de guerra bem-feitas. Os soldados remavam/ guerreiros
} 
especializado de metáfora em que uma palavra composta passa a ter um significado bastante diferente do que a mera soma de seus vocábulos constituintes dariam a entender. Assim, por exemplo, woruld-candel, "a vela do mundo", é o Sol; ban-hus, "a casa de ossos, a casa cujos pilares são os ossos", é o corpo humano; e assim por diante. Em The monsters $\&$ the critics and other essays, Tolkien, ao falar de Beowulf, resume a natureza do poema de forma que se aplica, em maior ou menor grau, a boa parte do verso anglo-saxão que chegou até nós:

"Finally, Beowulf itself is like a line of its own verse written large, a balance of two great blocks, $A+B$; or like two of its parallel sentences with a single subject but no expressed conjunction. Youth + Age; he rose - fell. It may not be, at large or in detail, fluid or musical, but it is strong to stand: tough builder's work of true stone". 


\section{On Fairy-Stories}

Abrindo a coletânea de textos, On fairy-stories não poderia ser mais programático. É um statement claro dos valores e possibilidades que Tolkien via nas estórias de fadas, parte exploração teórica, parte prosa poética e parte especulação teológica (não necessariamente nessa ordem cronológica ou de importância). Tom Shippey o define como uma espécie de apologia pro vita sua ${ }^{15}$ do autor, uma maneira de justificar, tanto no nível acadêmico e artístico quanto no pessoal e mesmo espiritual, as preocupações que o acompanharam durante toda a carreira.

O ensaio foi originalmente composto como uma palestra da série Andrew Lang, a qual foi pronunciada na Universidade de St. Andrews, na Escócia, em 8 de março de 1939. Sua primeira versão impressa apareceu no volume comemorativo Essays presented to Charles Williams (Oxford, 1947) e, depois, junto com Leaf by Niggle na primeira edição de Tree and leaf (1964).

Dividido em seções temáticas, o texto não segue uma linha de argumentação única: sua estrutura é mais radial, quase uma teia de aranha de idéias relacionadas, mas que não derivam necessariamente uma da outra. Caracteristicamente, o ponto de partida de Tolkien é filológico: o que a expressão "estória de fadas" significa nos termos do Oxford English dictionary (em cuja elaboração, ironicamente, o próprio autor trabalhou) e qual é o abismo entre essa definição dicionarizada, a história da expressão e o uso dela na linguagem viva do dia-a-dia.

De fato, Tolkien parece decidido a corrigir o que vê como uma série de equívocos a respeito das estórias de fadas, boa parte deles cometidos pelos estudos de filologia e mitologia comparadas que foram tão importantes durante o século 19, pelas mãos de folcloristas como o escocês Andrew Lang (em honra de quem Tolkien proferiu pela primeira vez o ensaio). Para o autor, passou-se tempo demais usando estórias de fadas e mitos como fontes de informação sobre costumes tribais ancestrais, história oral, evolução de famílias lingüísticas etc. e tempo de menos considerando a importância e o papel das estórias como estórias, como narrativas que parecem brotar de um impulso humano primordial: o impulso para criar Mundos Secundários, para lidar com a Fantasia.

\footnotetext{
${ }^{15}$ Shippey (comunicação pessoal, 2003).
} 
A partir daí, entra em cena uma das principais preocupações de Tolkien no "mundo real": os dilemas que a civilização industrial estava impondo sobre a humanidade, antes dotada apenas do poder "sub-criativo" e agora agraciada com a capacidade de transformar a própria natureza dos demais seres vivos e da Terra com a força bruta da tecnologia. É talvez nesse ponto que Tolkien, apesar de todo o seu apego à tradição medieval da Inglaterra, revela-se mais distintamente moderno, um autor tipicamente do século XX. Como veterano da Primeira Guerra Mundial e pai de rapazes que lutaram na Segunda Guerra Mundial, ele não alimenta mais ilusões sobre o suposto papel benfazejo e salvador do progresso e da tecnologia; ao contrário, Tolkien passa a considerar que a escravização tecnológica da natureza pode ter como subproduto a escravização do próprio homem. O papel da fantasia e da sub-criação é ajudar a fugir dessa armadilha: com elas, o homem deixa de ser escravo ou tirano da natureza para se tornar seu amante, argumenta Tolkien.

Mas, por meio da sua profunda fé católica, o autor entrevê nas estórias de fadas um potencial ainda mais elevado e, de certa maneira, mesmo redentor. Para designar essa fagulha divina da fantasia, Tolkien cunha o termo eucatástrofe, "a boa catástrofe", correspondente à súbita virada da desesperança para o final feliz que, segundo ele, é a marca das grandes e verdadeiras estórias de fadas. Numa das cartas freqüentes e carinhosas que enviou ao seu filho predileto, Christopher, quando o rapaz servia na Real Força Aérea na África do Sul em 1944, Tolkien tenta explicar essa sensação. O autor recorda que associou seu ensaio, então já escrito, à história da cura milagrosa e inesperada de um menino no santuário de Nossa Senhora de Lourdes, na França. Essa emoção, conta ele ao filho,

is quite unlike any other sensation. And all of a sudden I realized what it was: the very thing that I had been trying to write about and explain in that fairy-story that I so much wish you had read (...) For it I coined the word 'eucatastrophe': the sudden happy turn in a story that pierces you with a joy that brings tears. (...) And I was there led to the view that it produces its peculiar effect because it is a sudden glimpse of Truth, your whole nature chained in material cause and effect, the chain of death, feels a sudden relief as if a major limb out of joint had suddenly snapped back. It perceives (...) that is indeed how 
things really do work in the Great World for which our nature is made. And I concluded by saying that the Resurrection was the greatest 'eucatastrophe' possible in the greatest Fairy Story - and produces that essential emotion: Christian joy that produces tears because it is qualitatively so like sorrow, because it comes from those places where joy and sorrow are at one, reconciled, as selfishness and altruism are lost in Love. Of course I do not mean that the Gospels tell what is only ${ }^{16}$ a fairy-story; but I do mean very strongly that they do tell a fairy-story: the greatest. Man the storyteller would have to be redeemed in a manner consonant with his nature: by a moving story. (CARPENTER, 1995, p. 100-101)

Se a avaliação de Shippey sobre a natureza íntima do ensaio, a de uma apologia pro vita sua, está correta, então vemos Tolkien na busca de um papel quase sagrado para a função de contador de estórias, na qual a capacidade humana para a "subcriação" contribui para o enriquecimento incessante da Criação divina da qual ela derivou.

A presente tradução busca deixar explícitas as características formais do texto original que permitem a abordagem ao mesmo tempo acadêmica, poética e teológica do tema que Tolkien adota. Destacam-se, entre elas, a escolha vocabular cuidadosa, que mantém quase sempre um olho sobre a história e a etimologia da língua; e a sintaxe e o fraseado superficialmente "neutros" e modernos, mas que, por meio de disjunções sutis que resvalam para o poético, o arcaico e mesmo o bíblico, alcançam um nível de expressividade tipicamente tolkieniano. Aspectos pontuais da tradução serão tratados com notas. É interessante notar a amarração próxima que existe entre o presente ensaio e o poema Mythopoeia: a estrofe central desse conclui uma das seções do texto em prosa. Trata-se de uma carta fictícia para C.S. Lewis, o melhor amigo de Tolkien, cujo tema é justamente a importância e a validade dos mitos, dentro do contexto do mito cristão - que, para Tolkien, é o mito por excelência a adentrar o Mundo Primário, a realidade.

Salvo onde indicado, as notas de rodapé são do próprio Tolkien.

\footnotetext{
${ }^{16}$ Grifo do próprio Tolkien (em itálico no original).
} 


\section{ON FAIRY-STORIES}

I propose to speak about fairy-stories, though I am aware that this is a rash adventure. Faerie is a perilous land, and in it are pitfalls for the unwary and dungeons for the overbold. And overbold I may be accounted, for though I have been a lover of fairystories since I learned to read, and have at times thought about them, I have not studied them professionally. I have been hardly more than a wandering explorer (or trespasser) in the land, full of wonder but not of information.

The realm of fairy-story is wide and deep and high and filled with many things: all manner of beasts and birds are found there; shoreless seas and stars uncounted; beauty that is an enchantment, and an ever-present peril; both joy and sorrow as sharp as swords. In that realm a man may, perhaps, count himself fortunate to have wandered, but its very richness and strangeness tie the tongue of a traveller who would report them. And while he is there it is dangerous for him to ask too many questions, lest the gates should be shut and the keys be lost.

There are, however, some questions that one who is to speak about fairy-stories must expect to answer, or attempt to answer, whatever the folk of Faerie may think of his impertinence. For instance: What are fairy stories? What is their origin? What is the use of them? I will try to give answers to these questions, or such hints of answers to them as I have gleaned - primarily from the stories themselves, the few of all their multitude that I know. 


\section{SOBRE ESTÓRIAS ${ }^{17}$ DE FADAS}

Proponho falar sobre estórias de fadas, embora esteja ciente de que essa é uma aventura temerária. Feéria ${ }^{18}$ é uma terra perigosa, e nela há armadilhas para os descuidados e masmorras para os ousados demais. E ousado demais posso ser considerado, pois embora eu tenha sido um amante das estórias de fadas desde que aprendi a ler, e tenha às vezes pensado a respeito delas, não as tenho estudado profissionalmente. Tenho sido dificilmente mais que um explorador (ou invasor) errante, cheio de assombro, mas não de informação.

O reino das estórias de fadas é amplo e profundo e alto e cheio de muitas coisas: toda maneira ${ }^{19}$ de feras e pássaros é encontrada lá; mares sem-litoral e estrelas incontáveis; beleza que é encantamento, e perigo sempre presente; alegria e tristeza tão cortantes quanto espadas. Nesse reino um homem pode, talvez, considerar-se afortunado por ter vagado, mas sua própria riqueza e estranheza amarram a língua de um viajante que quiser relatá-las. E, enquanto ainda está lá, é perigoso para ele fazer perguntas de mais, porque ${ }^{20}$ os portões podem se trancar e as chaves se perder.

Há, entretanto, algumas perguntas que alguém que vai falar sobre estórias de fadas deve esperar responder, ou tentar responder, seja lá o que o povo de Feéria possa pensar de sua impertinência. Por exemplo: o que são estórias de fadas? Qual é sua origem? Qual o uso delas? Tentarei dar respostas a essas questões, ou tais pistas de respostas como as que tenho colhido - primariamente das próprias estórias, as poucas de toda a multidão delas que conheço.

\footnotetext{
${ }^{17}$ A distinção entre story e history é fundamental em diversas passagens do texto - daí a decisão de "exumar" a palavra "estória" do túmulo onde a norma culta do português a havia enterrado nas últimas décadas. Creio que o procedimento é bastante defensável quando se leva em conta que a mesma confusão de ortografia e sentido acabou dando origem ao par story e history em inglês, ainda que séculos antes da adoção (passageira, segundo o bom gosto) da distinção em português. Um dos principais argumentos para rejeitar "estória" no nosso idioma - a de que tratar-se-ia de uma simples variante ortográfica elevada à categoria de variante semântica -, se aplicado ao inglês, acabaria decretando a "execução" de history. Além do mais, "estória" ainda parece estar viva no vocabulário que a maioria dos falantes do português usa para se referir ao tema deste ensaio. (N. do T.)

${ }^{18}$ Ver pág. 16 acima para uma justificativa do uso de "Feéria" em português. Um dado curioso é que outras traduções recentes - das histórias em quadrinhos do escritor britânico Neil Gaiman - viram-se diante do dilema de recriar Faërie em português, optando por "Fandal" (possivelmente uma combinação de infixo e sufixo sobre a base "Fada"). Minha preferência foi por uma palavra que mantivesse conexões com o uso natural em português. Há, no entanto, uma desvantagem óbvia: nos (poucos) casos em que são feitos trocadilhos que justapõem fairy e Faërie, a correspondência fica prejudicada. (N. do T.)

${ }^{19}$ Seria no mínimo falso traduzir all manner por "todo tipo", daí a preferência por um termo que, embora pouco natural em português, reflete a mesma falta de coloquialismo do original. (N. do T.)

${ }^{20} \mathrm{Em}$ inglês, lest tem conotação ao mesmo tempo adversativa e de negação, difícil de reproduzir. (N. do T.)
} 


\section{FAIRY-STORY}

What is a fairy-story? In this case you will turn to the Oxford English Dictionary in vain. It contains no reference to the combination fairy-story, and is unhelpful on the subject of fairies generally. In the Supplement, fairy-tale is recorded since the year 1750 , and its leading sense is said to be $(a)$ a tale about fairies, or generally a fairy legend; with developed senses, $(b)$ an unreal or incredible story, and (c) a falsehood.

The last two senses would obviously make my topic hopelessly vast. But the first sense is too narrow. Not too narrow for an essay; it is wide enough for many books, but too narrow to cover actual usage. Especially so, if we accept the lexicographer's definition of fairies: 'supernatural beings of diminutive size, in popular belief supposed to possess magical powers and to have great influence for good or evil over the affairs of man'.

Supernatural is a dangerous and difficult word in any of its senses, looser or stricter. But to fairies it can hardly be applied, unless super is taken merely as a superlative prefix. For it is man who is, in contrast to fairies, supernatural (and often of diminutive stature); whereas they are natural, far more natural than he. Such is their doom. The road to fairyland is not the road to Heaven; nor even to Hell, I believe, though some have held that it may lead thither indirectly by the Devil's tithe.

O see ye not yon narrow road

So thick beset wi' thorns and briers?

That is the path to Righteousness 


\section{ESTÓRIA DE FADAS}

O que é uma estória de fadas? Nesse caso, vocês vão recorrer ao Oxford English Dictionary em vão. Ele não contém nenhuma referência à combinação "estória de fadas" e é inútil quanto ao tema das fadas em geral. No Suplemento, conto de fadas está registrado desde o ano de 1750, e se diz que sua acepção principal é (a) um conto sobre fadas, ou geralmente uma lenda sobre fadas; com acepções ampliadas (b) uma estória irreal ou incrível, e (c) uma falsidade.

As duas últimas acepções obviamente tornariam o meu tema irrecuperavelmente vasto. Mas a primeira acepção é estreita demais. Não estreita demais para um ensaio: ela é ampla o suficiente para muitos livros, mas estreita demais para cobrir o uso real. Especialmente se aceitarmos a definição do lexicógrafo para fadas: "seres sobrenaturais de tamanho diminuto; na crença popular, considerados possuidores de poderes mágicos e donos de grande influência para o bem ou para o mal sobre os assuntos do homem".

Sobrenatural é uma palavra perigosa e difícil em qualquer de seus sentidos, mais amplos ou mais estritos. Mas às fadas ela dificilmente pode ser aplicada, a menos que sobre seja tomado meramente como um prefixo superlativo ${ }^{21}$. Pois é o homem que é, em contraste com as fadas, sobrenatural (e freqüentemente de estatura diminuta); enquanto elas são naturais, muito mais naturais que ele. Tal é a sua sina. A estrada para a terra das fadas não é a estrada para o Paraíso; nem mesmo a para o Inferno, acredito eu, embora alguns tenham sustentado que ela possa levar para lá indiretamente pelo dízimo do Diabo. ${ }^{22}$

\section{O see ye not yon narrow road}

So thick beset wi' thorns and briers?

That is the path of Righteousness

\footnotetext{
${ }^{21}$ É verdade que a conexão entre o prefixo sobre e a idéia de superlativo é mais tênue em português, mas ainda está presente em palavras como "sobre-humano", por exemplo. (N. do T.)

${ }^{22}$ O poema está em Southern Scots, dialeto do sul da Escócia, e foi recolhido pelo romancista Walter Scott para uma coletânea de canções populares publicada no século 19. Como se trata de uma citação de outro autor que marca um rompimento claro com a linha de raciocínio do texto, decidi mantê-la no original e apenas traduzir seu sentido geral abaixo. O mesmo procedimento foi adotado com a citação em Middle English de Gower. A idéia do dízimo do Diabo é encontrada em várias estórias de fadas da tradição inglesa - tal como a Atenas de Teseu, que mandava sete moças e sete rapazes para serem devorados pelo Minotauro todos os anos, Feéria mandaria dez de seus habitantes todos os anos para o Inferno a título de "dízimo". (N. do T.)
} 
Though after it but few inquires.

And see ye not yon braid, braid road

That lies across the lily leven?

That is the path of Wickedness,

Though some call it the Road to Heaven.

And see ye not yon bonny road

That winds about yon fernie brae?

That is the road to fair Elfland,

Where thou and I this night maun gae.

As for diminutive size: I do not deny that that notion is a leading one in modern use. I have often thought that it would be interesting to try to find out how that has come to be so; but my knowledge is not sufficient for a certain answer. Of old there were indeed some inhabitants of Faerie that were small (though hardly diminutive), but smallness was not characteristic of that people as a whole. The diminutive being, elf or fairy, is (I guess) in England largely a sophisticated product of literary fancy ${ }^{23}$. It is perhaps not unnatural that in England, the land where the love of the delicate and fine has often reappeared in art, fancy should in this matter turn towards the dainty and diminutive, as in France it went to court and put on powder and diamonds. Yet I suspect that this flower-and-butterfly minuteness was also a product of 'rationalisation', which transformed the glamour of Elfland into mere finesse, and invisibility into a fragility that could hide in a cowslip or shrink behind a blade of grass. It seems to become fashionable soon after the great voyages had begun to make the world seem too narrow

\footnotetext{
${ }^{23}$ I am speaking of developments before- the growth of interest in the folk-lore of other countries. The English words, such as elf, have long been influenced by French (from which fay and faërie, fairy are derived); but in later times, through their use in translation, both fairy and elf have acquired much of the atmosphere of German, Scandinavian, and Celtic tales, and many characteristics of the huldu-fólk, the daoine-sithe, and the tylwyth teg.
} 
Though after it but few inquires.

And see ye not yon braid, braid road

That lies across the lily leven?

That is the path of Wickedness

Though some call it the Road to Heaven

And see ye not yon bonny road

That winds about yon fernie brae?

That is the road to fair Elfland

Where thou and I this night maun gae ${ }^{24}$

Quanto ao tamanho diminuto: não nego que a idéia seja dominante no uso moderno. Freqüentemente achei que seria interessante tentar descobrir como veio a ser assim: mas meu conhecimento não é suficiente para uma resposta segura. Outrora havia de fato alguns habitantes de Feéria que eram pequenos (embora dificilmente diminutos), mas a pequenez não era característica daquele povo como um todo. $\mathrm{O}$ ser diminuto, elfo ou fada, é (suspeito) na Inglaterra, em grande parte, um produto sofisticado do devaneio literário. ${ }^{25}$ Talvez não seja antinatural que na Inglaterra, o país onde o amor do delicado e sutil tem freqüentemente reaparecido na arte, o devaneio nesse assunto se voltasse para o minúsculo e diminuto, como na França foi para a corte e foi colocado em pó-dearroz e diamantes. Contudo, suspeito que essa pequenez de flor-e-borboleta foi também um produto da "racionalização", que transformou o glamour da Terra dos Elfos em mera finesse, e a invisibilidade numa fragilidade que poderia se esconder dentro de uma prímula ou se encolher atrás de uma folha de relva. Ela parece entrar na moda logo depois que as grandes viagens tinham começado a fazer o mundo parecer estreito

\footnotetext{
${ }^{24}$ Oh, não vedes adiante estrada estreita/ Tão grossamente cercada por espinhos e arbustos?/ Esse é o caminho da Retidão/ Embora atrás dele só poucos inquiram/E não vedes adiante ampla, ampla estrada/ Que jaz através do lírio plana?/ Esse é o caminho da Perversidade/ Embora alguns o chamem de Estrada para o Céu/ E não vedes adiante estrada bela/ Que ondeia pelos bancos de samambaia adiante?/ Essa é a estrada para a bela Terra dos Elfos/ Aonde tu e eu nesta noite podemos ir (N. do T.)

${ }^{25}$ Estou falando de desenvolvimentos antes do crescimento do interesse pelo folclore de outros países. As palavras inglesas, tais como elfo, foram longamente influenciadas pelo francês (do qual fada e faéria, feéria são derivadas); mas em tempos posteriores, através de seu uso em tradução, tanto fada quanto elfo adquiriram muito da atmosfera dos contos alemães, escandinavos e célticos, e muitas características do huldu-fólk, do daoine-sithe e da tylwyth teg.
} 
to hold both men and elves; when the magic land of Hy Breasail in the West had become the mere Brazils, the land of red-dye-wood. ${ }^{26}$ In any case it was largely a literary business in which William Shakespeare and Michael Drayton played a part. ${ }^{27}$ Drayton's Nymphidia is one ancestor of that long line of flower-fairies and fluttering sprites with antennae that I so disliked as a child, and which my children in their turn detested. Andrew Lang had similar feelings. In the preface to the Lilac Pairy Book he refers to the tales of tiresome contemporary authors: 'they always begin with a little boy or girl who goes out and meets the fairies of polyanthuses and gardenias and appleblossom . . . These fairies try to be funny and fail; or they try to preach and succeed.' But the business began, as I have said, long before the nineteenth century, and long ago achieved tiresomeness, certainly the tiresomeness of trying to be funny and failing. Drayton's Nymphidia is, considered as a fairy-story (a story about fairies), one of the worst ever written. The palace of Oberon has walls of spider's legs,

And windows of the eyes of cats,

And for the roof, instead of slats, is covered with the wings of bats.

The knight Pigwiggen rides on a frisky earwig, and sends his love, Queen Mab, a bracelet of emmets' eyes, making an assignation in a cowslip-flower. But the tale that is told amid all this prettiness is a dull story of intrigue and sly go-betweens; the gallant knight and angry husband fall into the mire, and their wrath is stilled by a draught of the waters of Lethe. It would have been better if Lethe had swallowed the whole affair. Oberon, Mab, and Pigwiggen may be diminutive elves or fairies, as Arthur, Guinevere, and Lancelot are nor; but the good and evil story of Arthur' s court is a 'fairy-story' rather than this tale of Oberon.

Fairy, as a noun more or less equivalent to elf, is a relatively modern word, hardly used until the Tudor period. The first quotation in the

\footnotetext{
${ }^{26}$ For the probability that the Irish Hy Breasail played a part in the naming of Brazil see Nansen, In Northern Mists, ii, 223-30.

27 Their influence was not confined to England. German Elf, Elfe appears to be derived from $A$ Midsummer-night's Dream, in Wieland's translation (1764).
} 
demais para conter homens e elfos; quando a terra mágica de Hy Breasail ${ }^{28}$ no Oeste se tornou os meros Brasis, a terra da madeira do corante vermelho. ${ }^{29}$ Em todo caso, foi em grande parte um processo literário, no qual William Shakespeare e Michael Drayton tiveram um papel. A Nymphidia de Drayton é um ancestral daquela longa linhagem de fadas-das-flores e duendes flutuantes com antenas que tanto me desgostava quando criança, e que meus filhos por sua vez detestavam. Andrew Lang tinha sentimentos similares. No prefácio do Lilac Fairy Book ele se refere às estórias dos cansativos autores contemporâneos: "Elas sempre começam com um garotinho ou garotinha que sai e conhece as fadas dos poliantos, gardênias e macieiras.... Essas fadas tentam ser engraçadas e falham; ou tentam pregar e conseguem."

Mas o processo começou, como eu disse, muito antes do século XIX, e muito tempo atrás atingiu o cansaço, certamente o cansaço de tentar ser engraçado e falhar. A Nymphidia de Drayton é, considerada como estória de fadas (uma estória sobre fadas), uma das piores jamais escritas. O palácio de Oberon tem muros de pernas de aranha,

\section{Ejanelas de olhos de gato,}

E no teto, em vez de telhas,

É coberto com asas de morcego. ${ }^{30}$

O cavaleiro Pigwiggen cavalga uma lacraia saltitante, e manda para o seu amor, Rainha Mab, um bracelete de olhos de formigas, colocando sua assinatura numa prímula. Mas a estória que é contada em meio a toda essa delicadeza é um relato entediante de intriga e oblíquo leva-e-traz; o cavaleiro galante e o marido enraivecido caem na poça, e sua ira é detida por um gole das águas do Lete. Teria sido melhor se o Lete tivesse engolido o assunto inteiro. Oberon, Mab e Piggwiggen podem ser elfos ou fadas diminutos, como Arthur, Guinevere e Lancelot não são; mas a estória de bem e mal da corte de Arthur é mais uma "estória de fadas" do que essa estória de Oberon. Fada, como um substantivo mais ou menos equivalente a elfo, é uma palavra relativamente moderna, dificilmente usada até o período Tudor. A primeira citação no

\footnotetext{
${ }^{28}$ Em gaélico, "Ilha Abençoada", uma região maravilhosa do outro lado do Atlântico que teria sido visitada por São Brendan (ou Brandão) e às vezes é identificada com o Paraíso Terrestre. Manuscritos medievais irlandeses são os primeiros a registrar a história. Tolkien chegou a recontar parte da história em seu romance inacabado The Notion Club papers. (N. do T.)

${ }^{29}$ Sobre a probabilidade de que o irlandês Hy Breasail tenha tido um papel no batismo do Brasil ver Nansen, In Northern Mists, ii, 223-30.
} 
Oxford Dictionary (the only one before AD 1450) is significant. It is taken from the poet Gower: as he were a faierie. But this Gower did not say. He wrote as he were of faierie, 'as if he were come from Faerie'. Gower was describing a young gallant who seeks to bewitch the hearts of the maidens in church.

His croket kembd and thereon set

A Nouche with a chapelet

Or elles one of grene leves

Which late com out of the greves

Al for he sholde seme freissh;

And thus he loketh on the fleissh

Riht as an hauk which hath a sihte

Upon the foul ther he schal lithe

And as he were of faierie

He scheweth him tofore here $y e^{31}$

This is a young man of mortal blood and bone; but he gives a much better picture of the inhabitants of Elfland than the definition of a 'fairy' under which he is, by a double error, placed. For the trouble with the real folk of Faerie is that they do not always look like what they are; and they put on the pride and beauty that we would fain wear ourselves. At least part of the magic that they wield for the good or evil of man is power to play on the desires of his body and his heart. The Queen of Elfland, who carried off Thomas the Rhymer upon her milk-white steed swifter than the wind, came riding by the Eildon Tree as a lady, if one of enchanting beauty. So that Spenser was in the true tradition when he called the knights of his Faerie by the name of Elfe. It belonged to such knights as Sir Guyon rather than to Pigwiggen armed with a hornet's sting.

\footnotetext{
${ }^{30}$ Mais uma vez, por se tratar de uma citação (nesse caso encadeada diretamente com o fluxo do texto), a opção foi simplesmente traduzi-la pelo sentido (ver, mais abaixo, a citação de Gower). (N. do T.)

${ }^{31}$ Confessio Amantis, v. 7065 ff.
} 
Oxford Dictionary (a única antes de 1450) é significativa. É tirada do poeta Gower: as he were a faierie, "como se ele fosse uma fada". Mas isso Gower não disse. Ele escreveu as he were of faierie, "como se ele tivesse vindo de Feéria". Gower estava descrevendo um jovem galante que busca enfeitiçar os corações das donzelas na igreja.

\section{His croket kembd and thereon set}

A Nouche with a chapelet,

Or elles one of grene leves

Which late com out of the greves,

Al for he sholde seme freissh;

And thus he loketh on the fleissh,

Riht as an hauk which hath a sihte

Upon the foul ther he schal lithe,

And as he were of faierie

He scheweth him to fore here yhe. ${ }^{32}$

Esse é um jovem de sangue e osso mortais; mas ele dá um retrato muito melhor dos habitantes da Terra dos Elfos do que a definição de uma "fada" com a qual ele é, por um erro duplo, classificado. Pois o problema com a verdadeira gente de Feéria é que eles nem sempre parecem o que são; e envergam o orgulho e a beleza que de bom grado nós mesmos usaríamos. Pelo menos parte da mágica que eles usam para o bem ou mal do homem é o poder de brincar com os desejos de seu corpo e seu coração. A Rainha da Terra dos Elfos, que levou para longe Thomas, o Rimador, ${ }^{33}$ com seu corcel branco como o leite e mais rápido que o vento, chegou cavalgando à Árvore de Eildon como uma mulher, ainda que de beleza encantadora. De forma que Spenser $^{34}$ estava na tradição verdadeira quando chamou os cavaleiros de sua Feéria pelo nome de Elfos. Ele pertencia a cavaleiros tais como Sir Guyon, em vez de a Pigwiggen, armado com o ferrão de uma vespa.

\footnotetext{
${ }^{32}$ Confessio Amantis, v. 7065 ss. "Seus cachos penteados e sobre eles postos/Um lenço com um chapéu/Ou então guirlanda de folhas verdes/Que acabaram de sair dos campos/Tudo para que ele parecesse belo/E assim ele parecia na carne/Exatamente como um falcão que têm sua vista/No pássaro sobre o qual vai descer/E como se ele fosse de Feéria/Ele se mostrava diante dos olhos delas." (N. do T.) ${ }^{33}$ Trata-se de uma das versões clássicas do encontro entre mortal e elfo: o mortal se enamora da beleza élfica e passa uma noite ou alguns dias dançando entre as fadas. Quando retorna, décadas ou séculos se passaram e todas as pessoas que ele conhecia estão velhas ou já morreram. (N. do T.)
} 
Now, though I have only touched (wholly inadequately) on elves and fairies, I must turn back; for I have digressed from my proper theme: fairy-stories. I said the sense 'stories about fairies' was too narrow. ${ }^{35}$ It is too narrow, even if we reject the diminutive size, for fairy-stories are not in normal English usage stories about fairies or elves, but stories about Fairy, that is Faerie, the realm or state in which fairies have their being. Faerie contains many things besides elves and fays, and besides dwarfs, witches, trolls, giants, or dragons: it holds the seas, the sun, the moon, the sky; and the earth, and all things that are in it: tree and bird, water and stone, wine and bread, and ourselves, mortal men, when we are enchanted.

Stories that are actually concerned primarily with 'fairies', that is with creatures that might also in modern English be called 'elves', are relatively rare, and as a role not very interesting. Most good 'fairy stories' are about the aventures of men in the Perilous Realm or upon its shadowy marches. Naturally so; for if elves are true, and really exist independently of our tales about them, then this also is certainly true: elves are not primarily concerned with us, nor we with them. Our fates are sundered, and our paths seldom meet. Even upon the borders of Faerie we encounter them only at some chance crossing of the ways. ${ }^{36}$

The definition of a fairy-story - what it is, or what it should be - does not, then, depend on any definition or historical account of elf or fairy, but upon the nature of Faerie: the Perilous Realm itself, and the air that blows in that country. I will not attempt to define that, nor to describe it directly. It cannot be done. Faerie cannot be caught in a net of words; for it is one of its qualities to be indescribable,

\footnotetext{
${ }^{34}$ Tolkien se refere aqui a The Faerie Queene, o épico alegórico de Spenser. (N. do T.)

${ }^{35}$ Except in special cases such as collections of Welsh or Gaelic tales. In these the stories about the 'Fair Family' or the Shee-folk are sometimes distinguished as 'fairy-tales' from 'folk-tales' concerning other marvels. In this use 'fairy-tales' or 'fairy-lore' are usually short accounts of the appearances of 'fairies' or their intrusions upon the affairs of men. But this distinction is a product of translation.

${ }^{36}$ This is true also, even if they ate only creations of Man's mind, 'true' only as reflecting in a particular way one of Man's visions of Truth.
} 
Agora, embora eu tenha apenas tocado (de forma totalmente inadequada) no assunto de elfos e fadas, devo dar meia-volta; pois digredi de meu tema propriamente dito: estórias de fadas. Eu disse que a acepção "estórias sobre fadas" era estreita demais. ${ }^{37}$ Ela é estreita demais, mesmo se rejeitarmos o tamanho diminuto, pois estórias de fadas não são, no uso normal em inglês, estórias sobre fadas ou elfos, mas estórias sobre Fada, que é Feéria ${ }^{38}$, o reino ou estado no qual as fadas têm seu ser. Feéria contém muitas coisas além de elfos e fadas, e além de anões, bruxas, trolls, gigantes ou dragões: ela abriga os mares, o sol, a lua, o céu; e a terra, e todas as coisas que estão nela: árvore e pássaro, água e pedra, vinho e pão, e nós mesmos, homens mortais, quando estamos encantados.

Estórias que estão de fato preocupadas primariamente com "fadas", isto é, com criaturas que poderiam também, em inglês moderno, ser chamadas de "elfos", são relativamente raras, e via de regra não muito interessantes. A maioria das boas "estórias de fadas" são sobre as aventures ${ }^{39}$ de homens no Reino Perigoso ou em suas fronteiras imprecisas. Naturalmente que é assim; pois se os elfos são verdadeiros, e realmente existem independentemente de nossas estórias sobre eles, então isto também é certamente verdadeiro: os elfos não estão primariamente preocupados conosco, nem nós com eles. Nossos destinos são separados, e nossas trilhas raramente se encontram. Mesmo nas bordas de Feéria os encontramos apenas devido a alguma encruzilhada casual dos caminhos. ${ }^{40}$

A definição de uma estória de fadas - o que é, ou o que deveria ser - não depende, então, de qualquer definição ou relato histórico de elfo ou fada, mas da natureza de Feéria: o próprio Reino Perigoso, e o ar que sopra naquele país. Não tentarei defini-lo, ou descrevê-lo diretamente. Isso não pode ser feito. Feéria não pode ser capturada numa rede de palavras; pois é uma de suas qualidades ser indescritível,

\footnotetext{
${ }^{37}$ Exceto em casos especiais, tais como coleções de histórias galesas e gaélicas. Nessas, as histórias sobre a "Bela Família" ou a gente-shee são às vezes distinguidas dos "contos populares" relativos a outras maravilhas como "contos de fadas". Nesse uso, "contos de fadas" ou "tradição das fadas" são geralmente relatos curtos das aparições das "fadas" ou de suas intrusões nos assuntos dos homens. Mas essa distinção é produto da tradução.

${ }^{38}$ O único exemplo de uma contraposição realmente mais brusca, na tradução, entre "fada" e "Feéria". Não se pode ganhar todas. (N. do T.)

${ }^{39}$ Talvez pela própria associação de Feéria com o francês, Tolkien aqui usa a palavra francesa. Não é impossível que o emprego seja etimológico - com um sentido que fica mais próximo de "acontecimentos" do que de "aventuras". (N. do T.)

${ }^{40}$ Isso também é verdade mesmo que eles sejam apenas criações da mente do Homem, "verdadeiros" apenas enquanto refletem de maneira particular uma das visões do Homem sobre a Verdade.
} 
though not imperceptible. It has many ingredients, but analysis will not necessarily discover the secret of the whole. Yet I hope that what I have later to say about the other questions will give some glimpses of my own imperfect vision of it. For the moment I will say only this: a 'fairy-story' is one which touches on or uses Faerie, whatever its own main purpose may be: satire, adventure, morality, fantasy. Faerie itself may perhaps most nearly be translated by Magic ${ }^{41}$ - but it is magic of a peculiar mood and power, at the furthest pole from the vulgar devices of the laborious, scientific, magician. There is one proviso: if there is any satire present in the tale, one thing must not be made fun of, the magic itself. That must in that story be taken seriously, neither laughed at nor explained away. Of this seriousness the medieval Sir Gawain and the Green Knight is an admirable example.

But even if we apply only these vague and ill-defined limits, it becomes plain that many, even the learned in such matters, have used the term 'fairy-tale' very carelessly. A glance at those books of recent times that claim to be collections of 'fairy-stories' is enough to show that tales about fairies, about the fair family in any of its houses, or even about dwarfs and goblins, are only a small part of their content. That, as we have seen, was to be expected. But these books also contain many tales that do not use, do not even touch upon, Faerie at all; that have in fact no business to be included.

I will give one or two examples of the expurgations I would perform. This will assist the negative side of definition. It will also be found to lead on to the second question: what are the origins of fairy-stories?

The number of collections of fairy-stories is now very great. In English none probably rival either the popularity, or the inclusiveness, or the general merits of the twelve books of twelve colours which we owe to Andrew Lang and to his wife. The first of these appeared more than fifty years ago (1889), and is still in print. Most of its contents pass the test more or less clearly. I will not analyse them, though an analysis might be interesting; but I note in passing that of the stories in this Blue Fairy Book none are primarily about 'fairies', few refer to them. Most of the tales are taken from French sources: a just choice in some

\footnotetext{
${ }^{41}$ See further below, p. 53.
} 
embora não imperceptível. Ela tem muitos ingredientes, mas a análise ${ }^{42}$ não necessariamente descobrirá o segredo do todo. Contudo, espero que o que tenho depois a dizer sobre as outras questões dará alguns vislumbres da minha própria visão imperfeita dela. Para o momento direi apenas isto: uma "estória de fadas" é a que toca ou usa Feéria, qualquer que seu próprio propósito central possa ser: sátira, aventura, moralidade, fantasia. A própria Feéria possa talvez ser traduzida mais proximamente por Magia $^{43}$ - mas é magia de um ânimo e poder peculiar, no pólo oposto ao dos artifícios vulgares do mágico laborioso e científico. Há um proviso: se há alguma sátira presente na estória, de uma coisa não se pode zombar, da magia em si. Essa deve, naquela estória, ser levada a sério; nem ridicularizada nem explicada. Dessa seriedade o medieval Sir Gawain e o Cavaleiro Verde $e^{44}$ é um exemplo admirável.

Mas mesmo se aplicarmos apenas esses limites vagos e mal-definidos, torna-se claro que muitos, mesmo os eruditos em tais assuntos, têm usado o termo "conto de fadas" de forma muito descuidada. Uma olhada nos livros de tempos recentes que afirmam ser coleções de "estórias de fadas" é suficiente para mostrar que contos sobre fadas, sobre a bela família em qualquer uma de suas casas, ou mesmo sobre anões e duendes, são só uma pequena parte de seu conteúdo. Isso, como vimos, era de esperar. Mas esses livros também contêm muitos contos que não usam Feéria, nem mesmo tocam nela de algum jeito; que, de fato, não têm motivo para serem incluídos.

Darei um ou dois exemplos dos expurgos que eu realizaria. Isso ajudará no lado negativo da definição. Também acabará por levar à segunda questão: quais são as origens das estórias de fadas?

O número de coleções de estórias de fadas é agora muito grande. Em inglês nenhuma provavelmente rivaliza a popularidade, a inclusividade ou os méritos gerais dos doze livros de doze cores que devemos a Andrew Lang e sua esposa. O primeiro desses apareceu mais de cinqüenta anos atrás (1889) e ainda está sendo impresso. A maior parte de seu conteúdo passa no teste, mais ou menos claramente. Não vou analisálo, embora uma análise pudesse ser interessante, mas noto de passagem que, das estórias nesse Blue Fairy Book, nenhuma é primariamente sobre "fadas", poucas se referem a elas. A maioria das estórias é tirada de fontes francesas: uma escolha justa, de certa

\footnotetext{
${ }^{42} \mathrm{O}$ primeiro dos muitos golpes irônicos que Tolkien desfere no chamado "método analítico" que a ciência consagrou. (N. do T.)

${ }^{43}$ Ver mais abaixo, p. 52.

${ }^{44}$ Poema medieval no dialeto das Midlands Ocidentais que Tolkien traduziu para o inglês moderno e que emprega, em sua versão tardia, a rima aliterativa.
} 
ways at that time, as perhaps it would be still (though not to my taste, now or in childhood). At any rate, so powerful has been the influence of Charles Perrault, since his Contes de ma Mère l'Oye were first Englished in the eighteenth century, and of such other excerpts from the vast storehouse of the Cabinet des Fées as have become well known, that still, I suppose, if you asked a man to name at random a typical 'fairy-story', he would be most likely to name one of these French things: such as Puss-in-Boots, Cinderella, or Little Red Riding Hood. With some people Grimm's Fairy Tales might come first to mind.

But what is to be said of the appearance in the Blue Fairy Book of $A$ Voyage to Lilliput? I will say this: it is not a fairy-story, neither as its author made it, nor as it here appears 'condensed' by Miss May Kendall. It has no business in this place. I fear that it was included merely because Lilliputians are smalI, even diminutive the only way in which they are at all remarkable.

But smallness is in Faerie, as in our world, only an accident. Pygmies are no nearer to fairies than are Patagonians. I do not rule this story out because of its satirical intent: there is satire, sustained or intermittent, in undoubted fairy-stories, and satire may often have been intended in traditional tales where we do not now perceive it. I rule it out, because the vehicle of the satire, brilliant invention though it may be, belongs to the class of travellers' tales. Such tales report many marvels, but they are marvels to be seen in this mortal world in some region of our own time and space; distance alone conceals them. The tales of Gulliver have no more right of entry than the yarns of Baron Munchausen; or than, say, The First Men in the Moon or The Time-Machine. Indeed, for the Eloi and the Morlocks there would be a better claim than for the Lilliputians. Lilliputians are merely men peered down at, sardonically, from just above the house-tops. Eloi and Morlocks live far away in an abyss of time so deep as to work an enchantment upon them; and if they are descended from ourselves, it may be remembered that an ancient English thinker once 
maneira, naquele tempo, como talvez seria ainda (embora não para o meu gosto, agora ou na infância). De qualquer modo, tão forte tem sido a influência de Charles Perrault, desde que seus Contes de ma Mère l'Oye foram pela primeira vez anglicizados no século XVIII, e a de todos os semelhantes excertos da vasta reserva do Cabinet des Fées $^{i}$ que se tornaram bem conhecidos, que ainda, suponho, se você pedisse a um homem para citar ao acaso uma típica "estória de fadas", ele muito provavelmente citaria uma destas coisas francesas: Gato-de-botas, Cinderela ou Chapeuzinho Vermelho. Com algumas pessoas os Contos de Fadas de Grimm poderiam vir primeiro à mente.

Mas o que deve ser dito sobre a aparição no Blue Fairy Book de Uma Viagem a Lilliput? Direi isto: não é uma estória de fadas, nem como seu autor a criou, nem como ali aparece "condensada" pela senhorita May Kendall. Não tem motivo para estar nesse lugar. Temo que tenha sido incluída apenas porque os lilliputianos são pequenos, mesmo diminutos - a única maneira na qual são de algum modo notáveis. Mas a pequenez é em Feéria, como em nosso mundo, apenas um acidente. Pigmeus não estão mais próximos de fadas do que patagões. Não deixo de fora essa estória por causa de seu intento satírico: há sátira, contínua ou intermitente, em estórias de fadas inquestionáveis, e a sátira pode ter sido freqüentemente pretendida em contos tradicionais onde nós agora não a percebemos. Eu a deixo de fora porque o veículo da sátira, por invenção brilhante que possa ser, pertence à classe das estórias de viajantes.Tais estórias relatam muitas maravilhas, mas elas são maravilhas a serem vistas neste mundo mortal, em alguma região de nosso próprio tempo e espaço; distância apenas as oculta. Os contos de Gulliver não têm mais direito de entrada do que as divagações do Barão de Munchausen; ou do que, digamos, Os Primeiros Homens na Lua ou A Máquina do Tempo. ${ }^{45}$ De fato, para os Eloi e os Morlocks haveria um direito maior do que para os lilliputianos. Os lilliputianos são meramente homens olhados de cima, sardonicamente, de pouco mais que o alto das casas. Eloi e Morlocks vivem muito longe num abismo de tempo tão profundo que opera um encantamento sobre eles; e se descendem de nós mesmos, pode-se lembrar que um antigo pensador inglês certa vez

\footnotetext{
${ }^{45}$ Tolkien parece ter tido grande apreço por pelo menos algumas das histórias de H.G. Wells, e um interesse profundo pela ficção científica do fím do século XIX e começo do século XX. Na tentativa de "corrigir" alguns dos defeitos de A Máquina do Tempo e de cumprir um plano conjunto com C. S. Lewis, ele chegou a começar por duas vezes um romance sobre viagens no tempo, sem terminar nenhuma das tentativas. (N. do T.)
} 
derived the $y l f e$, the very elves, through Cain from Adam. ${ }^{46}$ This enchantment of distance, especially of distant time, is weakened only by the preposterous and incredible Time Machine itself. But we see in this example one of the main reasons why the borders of fairy-story are inevitably dubious. The magic of Faerie is not an end in itself, its virtue is in its operations: among these are the satisfaction of certain printordial human desires.

One of these desires is to survey the depths of space and time. Another is (as will be seen) to hold communion with other living things. A story may thus deal with the satisfaction of these desires, with or without the operation of either machine or magic, and in proportion as it succeeds it will approach the quality and have the flavor of fairy-story.

Next, after travellers' tales, I would also exclude, or rule out of order, any story that uses the machinery of Dream, the dreaming of actual human sleep, to explain the apparent occurrence of its marvels. At the least, even if the reported dream was in other respects in itself a fairy-story, I would condemn the whole as gravely defective: like a good picture in a disfiguring frame. It is true that Dream is not unconnected with Faerie. In dreams strange powers of the mind may be unlocked. In some of them a man may for a space wield the power of Faerie, that power which, even as it conceives the story, causes it to take living form and colour before the eyes. A real dream may indeed sometimes be a fairy-story of almost elvish ease and skill - while it is being dreamed. But if a waking writer tells you that his tale is only a thing imagined in his sleep, he cheats deliberately the primal desire at the heart of Faerie: the realisation, independent of the conceiving mind, of imagined wonder. It is often reported of fairies (truly or lyingly, I do not know) that they are workers of illusion, that they are cheaters of men by 'fantasy'; but that is quite another matter. That is their affair. Such trickeries happen, at any fate, inside tales in which the fairies are not themselves illusions; behind the fantasy real wills and powers exist, independent of the minds and purposes of men.

\footnotetext{
${ }^{46}$ Beowulf, III-12.
} 
derivou os ylfe, os próprios elfos, por meio de Caim, de Adão. ${ }^{47}$ Esse encantamento de distância, especialmente de tempo distante, é enfraquecido apenas pela própria Máquina do Tempo absurda e incrível. Mas vemos nesse exemplo uma das razões pelas quais as fronteiras das estórias de fadas são inevitavelmente dúbias. A magia de Feéria não é um fim em si mesma, sua virtude está em suas operações: entre essas está a satisfação de certos desejos humanos primordiais. Um desses desejos é observar as profundezas do espaço e tempo. Outra é (como será visto) ter comunhão com outras coisas vivas. Uma estória pode assim lidar com a satisfação desses desejos, com ou sem a operação de máquina ou magia, e na proporção em que tiver sucesso aproximar-se-á da qualidade e terá o sabor de estória de fadas.

A seguir, depois das estórias de viajantes, eu também excluiria, ou julgaria imprópria, qualquer estória que usasse a maquinaria do Sonho, o sonhar do sono humano real, para explicar a aparente ocorrência de suas maravilhas. No mínimo, mesmo que o sonho relatado fosse em outros respeitos em si mesmo uma estória de fadas, eu condenaria o todo como gravemente defeituoso: como uma boa pintura numa moldura desfiguradora. É verdade que o sonho não está desconectado de Feéria. Nos sonhos estranhos poderes da mente podem ser destrancados. Em alguns deles um homem pode por algum tempo empunhar ${ }^{48}$ o poder de Feéria, aquele poder que, mesmo enquanto concebe a estória, faz com que ela tome forma e cor viva diante dos olhos. Um sonho verdadeiro pode de fato às vezes ser uma estória de fadas de facilidade e habilidade quase élfica - enquanto está sendo sonhado. Mas se um escritor desperto lhe diz que sua estória é só algo imaginado em seu sono, ele engana deliberadamente o desejo primevo no coração de Feéria: a realização, independente da mente que o concebe, do assombro imaginado. Freqüentemente se relata das fadas (verdadeira ou mentirosamente, eu não sei) que elas são criadoras de ilusão, que são enganadoras dos homens por meio da "fantasia"; mas isso é assunto bem diferente. Isso é assunto delas. Tais truques acontecem, de qualquer forma, dentro de estórias nas quais as fadas não são elas próprias ilusões; atrás da fantasia vontades e poderes reais existem, independentes das mentes e propósitos dos homens.

\footnotetext{
${ }^{47}$ Beowulf, 111-12. [A tese do autor anônimo do poema anglo-saxão é que o "ogro" Grendel e sua mãe descendem do filho mais velho de Adão, o mesmo valendo para todos os outros monstros ou criaturas não-humanas da mitologia germânica, como elfos e gigantes - N. do T.]

${ }^{48}$ Wield tem sentido mais forte e amplo que o do mero "usar" em português - daí a opção por "empunhar".
} 
It is at any rate essential to a genuine fairy-story, as distinct from the employment of this form for lesser or debased purposes, that it should be presented as 'true'. The meaning of 'true' in this connection I will consider in a moment. But since the fairy-story deals with 'marvels', it cannot tolerate any frame or machinery suggesting that the whole story in which they occur is a figment or illusion. The tale itself may, of course, be so good that one can ignore the frame. Or it may be successful and amusing as a dream-story. So are Lewis Carroll's Alice stories, with their dream-frame and dream-transitions. For this (and other reasons) they are not fairy-stories. ${ }^{49}$

There is another type of marvellous tale that I would exclude from the title 'fairystory', again certainly not because I do not like it: namely pure 'Beast-fable'. I will choose an example from Lang's Fairy Books: The Monkey's Heart, a Swahili tale which is given in the Lilac Fairy Book. In this story a wicked shark tricked a monkey into riding on his back, and carried him half-way to his own land, before he revealed the fact that the sultan of that country was sick and needed a monkey's heart to cure his disease. But the monkey outwitted the shark, and induced him to return by convincing him that the heart had been left behind at home, hanging in a bag on a tree.

The beast-fable has, of course, a connection with fairy-stories. Beasts and birds and other creatures often talk like men in real fairy-stories. In some part (often small) this marvel derives from one of the primal 'desires' that lie near the heart of Faerie: the desire of men to hold communion with other living things. But the speech of beasts in the beast-fable, as developed into a separate branch, has little reference to that desire, and often wholly forgets it. The magical understanding by men of the proper languages of birds and beasts and trees, that is much nearer to the true purposes of Faerie. But in stories in which no human being is concerned; or in which the animals are the heroes and heroines, and men and women, if they appear, are mere adjuncts; and above all those in which the animal form is only a mask upon a human face, a device of me satirist or the preacher, in these we have beast-fable and not fairy-story: whether it be Reynard the Fox, or The Nun's Priest's Tale, or Brer Rabbit, or merely The Three Little Pigs. The stories of

\footnotetext{
${ }^{49}$ See note $\mathrm{A}$ at the end
} 
É de qualquer forma essencial para uma estória de fadas genuína, distinta do emprego dessa forma para propósitos menores ou degradados, que ela seja apresentada como "verdadeira". O significado de "verdadeiro" nessa conexão eu considerarei num momento. Mas já que a estória de fadas lida com "maravilhas", ela não pode tolerar nenhuma moldura ou maquinaria sugerindo que a estória toda na qual elas ocorrem é um fingimento ou uma ilusão. O próprio conto pode, claro, ser tão bom que se pode ignorar a moldura. Ou pode ser bem-sucedido e divertido como uma estória sonhada. Assim são as estórias de Alice de Lewis Carroll, com sua moldura de sonho e transições de sonho. Por essa (e outras razões) elas não são estórias de fadas. ${ }^{50}$

Há outro tipo de estória maravilhosa que eu excluiria do título "estória de fadas", de novo certamente não porque eu não goste dela: nomeadamente, a pura "fábula de animais". Escolherei um exemplo dos Fairy Books de Lang: O Coração do Macaco, um conto suaíli que aparece no Lilac Fairy Book. Nessa estória, um tubarão malvado enganou um macaco para que ele cavalgasse nas suas costas, e o carregou até metade do caminho para sua própria terra, antes de revelar o fato de que o sultão daquele país estava doente e precisava de um coração de macaco para curar sua doença. Mas o macaco foi mais esperto que o tubarão, e o induziu a voltar convencendo-o de que o coração tinha ficado para trás em casa, pendurado dentro de uma bolsa numa árvore.

A fábula de animais tem, é claro, uma conexão com as estórias de fadas. Animais, pássaros e outras criaturas freqüentemente falam como homens em estórias de fadas verdadeiras. Em alguma medida (freqüentemente pequena) essa maravilha deriva de um dos "desejos" primordiais que estão perto do coração de Feéria: o desejo dos homens de ter comunhão com outras coisas vivas. Mas a fala dos animais numa fábula de animais, enquanto desenvolvida num ramo separado, tem pouca relação com esse desejo, e freqüentemente o esquece totalmente. A compreensão mágica, pelos homens, das línguas reais de pássaros e animais e árvores, isso está muito mais próximo dos verdadeiros propósitos de Feéria. Mas em estórias nas quais nenhum ser humano aparece; ou nas quais os animais são os heróis e heroínas, e homens e mulheres, se aparecerem, são meros adjuntos; e, acima de tudo, naquelas nas quais a forma animal é só uma máscara sobre um rosto humano, um artifício do satirista ou do pregador, nessas temos fábula de animais e não estória de fadas: seja Reynard, a Raposa, ou O Conto da Freira do Padre, ou Coelho Brer, ou meramente Os Três Porquinhos. As estórias de

\footnotetext{
${ }^{50}$ Ver Nota A no fim.
} 
Beatrix Potter lie near the borders of Faerie, but outside it, I think, for the most part. $^{51}$ Their nearness is due largely to their strong moral element: by which I mean their inherent morality, not any allegorical significatio. But Peter Rabbit, though it contains a prohibition, and though there are prohibitions in fairyland (as, probably, there are throughout the universe on every plane and in every dimension), remains a beast-fable.

Now The Monkey's Heart is also plainly only a beast-fable. I suspect that its inclusion in a 'Fairy Book' is due not primarily to its entertaining quality, but precisely to the monkey's heart supposed to have been left behind in a bag. That was significant to Lang, the student of folk-lore, even though this curious idea is here used only as a joke; for, in this tale, the monkey's heart was in fact quite normal and in his breast. None the less this detail is plainly only a secondary use of an ancient and very widespread folk-lore notion, which does occur in fairystories; ${ }^{52}$ the notion that the life or strength of a man or creature may reside in some other place or thing; or in some part of the body (especially the heart) that can be detached and hidden in a bag, or under a stone, or in an egg. At one end of recorded folk-lore history this idea was used by George MacDonald in his fairy story The Giant's Heart, which derives this central motive (as well as many other details) from well-known traditional tales. At the other end, indeed in what is probably one of the oldest stories in writing, it occurs in The Tale of the Two Brothers in the Egyptian D'Orsigny papyrus. There the younger brother says to the elder:

'I shall enchant my heart, and I shall place it upon the top of the flower of the cedar. Now the cedar will be cut down and my heart will fall to the ground, and thou shalt come to seek for it, even though thou pass seven years in seeking it; but when thou hast found it, put it in a vase of cold water, and in very truth I shall live. ${ }^{53}$

\footnotetext{
${ }^{51}$ The Tailor of Gloucester perhaps comes nearest. Mrs Tiggywinkle would be as near, but for the hinted dream-explanation. I would also include The Wind in the Willows in beast-fable.

${ }^{52}$ Such as, for instance: The Giant that had no Heart in Dasent's Popular Tales from the Norse; or The Sea-Maiden in Campbell's Popular Tales of the West Highlands (no. iv, cf. also no. i); or more remotely Die Kristallkugel in Grimm.

${ }^{53}$ Budge, Egyptian Reading Book, p. xxi.
} 
Beatrix Potter estão perto das fronteiras de Feéria, mas fora dela, acho, na maior parte. ${ }^{54}$ Sua proximidade se deve em grande parte ao seu forte elemento moral: pelo que quero dizer sua moralidade inerente, não alguma significatio alegórica. ${ }^{55}$ Mas Pedro, o Coelho, embora contenha uma proibição, e embora haja proibições na terra das fadas (como, provavelmente, há proibições através do universo em todo plano e toda dimensão), permanece uma fábula de animais.

Ora, O Coração do Macaco é também claramente apenas uma fábula de animais. Suspeito que sua inclusão num "Livro das Fadas" se deva não (primariamente) à sua qualidade de entreter, mas precisamente ao suposto coração do macaco deixado para trás numa bolsa. Isso era significativo para Lang, o estudioso do folclore, mesmo que essa idéia curiosa seja usada aqui apenas como uma piada; pois, nesse conto, o coração do macaco era de fato bem normal e estava em seu peito. Mesmo assim, esse detalhe é claramente apenas um uso secundário de uma idéia antiga e muito espalhada no folclore, que de fato ocorre nas estórias de fadas ${ }^{56}$; a idéia de que a vida ou força de um homem ou uma criatura pode residir em outro lugar ou outra coisa; ou em alguma parte do corpo (especialmente o coração) que possa ser retirada e guardada numa bolsa, ou sob uma pedra, ou num ovo. Numa ponta da história registrada do folclore, essa idéia foi usada por George McDonald em sua estória de fadas $O$ Coração do Gigante, que deriva seu motivo central (bem como muitos outros detalhes) de contos tradicionais bem-conhecidos. ${ }^{57} \mathrm{Na}$ outra ponta, de fato no que provavelmente é uma das mais antigas estórias escritas, ela ocorre em $O$ Conto dos Dois Irmãos no papiro egípcio D’Orsigny. Ali o irmão mais novo diz ao mais velho:

Eu encantarei meu coração, e o colocarei no alto da flor do cedro. Ora, o cedro será cortado e meu coração cairá ao chão, e tu virás buscá-lo, ainda que tu passes sete anos a buscá-lo; mas quando tu o encontrares, põe-no num vaso de água fria, e em verdade eu viverei. $^{58}$

\footnotetext{
${ }^{54}$ O Alfaiate de Gloucester talvez chegue mais perto. Sra. Tiggywinkle estaria tão perto quanto, se não fosse a sugerida explicação de sonho. Eu também incluiria $O$ Vento nos Salgueiros na fábula de animais. ${ }^{55} \mathrm{~A}$ implicância de Tolkien com a alegoria é quase folclórica, surgindo com força principalmente em sua ira diante das interpretações alegóricas de $\mathbf{O}$ senhor dos anéis. (N. do T.)

${ }^{56}$ Tais como, por exemplo: O Gigante que não tinha Coração nos Popular Tales from the Norse de Dasent; ou A Donzela do Mar nos Popular Tales of the West Highlands de Campbell (n. iv, cf. também n. i) ou mais remotamente Die Kristallkugel em Grimm.

${ }^{57}$ Coincidência ou não, o motivo da "força vital de um ser poderoso depositada em outro objeto" é justamente o ponto de partida de $\mathbf{O}$ senhor dos anéis - a vida de Sauron, o personagem-título, depende da existência do Um Anel. (N. do T.)

${ }^{58}$ Budge, Egyptian Reading Book, p. xxi
} 
But that point of interest and such comparisons as these bring us to the brink of the second question: What are the origins of 'fairy-stories'? That must, of course, mean: the origin or origins of the fairy elements. To ask what is the origin of stories (however qualified) is to ask what is the origin of language and of the mind.

\section{ORIGINS}

Actually the question: What is the origin of the fairy element? lands us ultimately in the same fundamental inquiry; but there are many elements in fairy-stories (such as this detachable heart, or swan-robes, magic rings, arbitrary prohibitions, wicked step-mothers, and even fairies themselves) that can be studied without tackling this main question. Such studies are, however, scientific (at least in intent); they are the pursuit of folklorists or anthropologists: that is of people using the stories not as they were meant to be used, but as a quarry from which to dig evidence, or information, about matters in which they are interested. A perfectly legitimate procedure in itself - but ignorance or forgetfulness of the nature of a story (as a thing told in its entirety) has often led such inquirers into strange judgements. To investigators of this sort recurring similarities (such as this matter of the heart) seem specially important. So much so that students of folklore are apt to get off their own proper track, or to express themselves in a misleading 'shorthand': misleading in particular, if it gets out of their monographs into books about literature. They are inclined to say that any two stories that are built round the same folklore motive, or are made up of a generally similar combination of such motives, are 'the same stories'.

We read that Beowulf'is only a version of Dat Erdmanneken'; that 'The Black Bull of Norroway is Beauty and the Beast', or 'is the same story as Eros and Psyche'; that the Norse Mastermaid (or the Gaelic Battle of the Birds ${ }^{59}$ and its many congeners and variants) is 'the same story as the Greek tale of Jason and Medea'.

\footnotetext{
${ }^{59}$ See Campbell, op. cit., voi. i.
} 
Mas esse ponto de interesse e tais comparações como essas nos levam à beira da segunda questão: quais são as origens das "estórias de fadas"? Isso deve, é claro, significar: a origem ou origens dos elementos de Feéria. Perguntar qual a origem das estórias (mesmo que qualificadas) é perguntar qual é a origem da língua e da mente.

\section{ORIGENS}

De fato, a questão "qual é a origem do elemento feérico" nos leva em última instância à mesma inquirição fundamental; mas há muitos elementos nas estórias de fadas (tais como esse coração destacável, ou trajes-cisne, anéis mágicos, proibições arbitrárias, madrastas malvadas, e mesmo as próprias fadas) que podem ser estudados sem atacar essa questão principal. Tais estudos são, entretanto, científicos (pelo menos em intenção); são o objetivo de folcloristas ou antropólogos: isto é, de pessoas usando as estórias não como elas foram destinadas a ser usadas, mas como uma pedreira na qual minerar evidência, ou informação, sobre assuntos nos quais estão interessadas. Um procedimento perfeitamente legítimo em si mesmo - mas a ignorância ou o esquecimento da natureza de uma estória (como uma coisa contada em sua inteireza) freqüentemente levou tais inquirições a julgamentos estranhos. Para investigadores desse tipo similaridades recorrentes (tais como a matéria ${ }^{60}$ do coração) parecem especialmente importantes. Tanto é assim que estudiosos do folclore estão prontos a sair de sua trilha apropriada, ou de se expressar em "atalhos" enganadores: enganadores, em particular, se saem de suas monografias para livros sobre literatura. Eles são inclinados a dizer que quaisquer duas estórias construídas em torno do mesmo motivo de folclore, ou que são feitas de uma combinação genericamente similar de tais motivos, são "as mesmas estórias". Lemos que Beowulf "é só uma versão de Dat Erdmänneken; ${ }^{61}$ que "O Touro Negro de Norroway é A Bela e a Fera" ou "é a mesma estória que Eros e Psiquê"; que a nórdica Donzela-mestra (ou a gaélica Batalha dos Pássaros ${ }^{62}$ e seus muitos congêneres e variantes) é "a mesma estória que o conto grego de Jasão e Medéia."

\footnotetext{
${ }^{60} \mathrm{O}$ sentido mais antigo de matter ou "matéria" - que se aproxima de "assunto", "tema" - é empregado por Tolkien de maneira não muito diferente do que se costumava empregar em português, e ainda se emprega em contextos jurídicos, por exemplo. (N. do T.)

${ }^{61}$ Uma das estórias de fadas da coletânea organizada pelos irmãos Grimm no século XIX.

${ }^{62}$ Ver Campbell, op. cit., vol. i.
} 
Statements of that kind may express (in undue abbreviation) some element of truth; but they are not true in a fairy-story sense, they are not true in art or literature. It is precisely the colouring, the atmosphere, the unclassifiable individual details of a story, and above all the general purport that informs with life the undissected bones of the plot, that really count. Shakespeare's King Lear is not the same as Layamon's Story in his Brut. Or to take the extreme case of Red Riding Hood: it is of merely secondary interest that the re-told versions of this story, in which the little girl is saved by wood-cutters, is directly derived from Perrault's story in which she was eaten by the wolf. The really important thing is that the later version has a happy ending (more or less, and if we do not mourn the grandmother overmuch), and that Perrault's version had not. And that is a very profound difference, to which I shall return.

Of course, I do not deny, for I feel strongly, the fascination of the desire to unravel the intricately knotted and ramified history of the branches on the Tree of Tales. It is closely connected with the philologists' study of the tangled skein of Language, of which I know some small pieces. But even with regard to language it seems to me that the essential quality and aptitudes of a given language in a living moment is both more important to seize and far more difficult to make explicit than its linear history. So with regard to fairy-stories, I feel that it is more interesting, and also in its way more difficult, to consider what they are, what they have become for us, and what values the long alchemic processes of time have produced in them. In Dasent's words I would say: 'We must be satisfied with the soup that is set before us, and not desire to see the bones of the ox out of which it has been boiled. ${ }^{63}$ Though, oddly enough, Dasent by 'the soup' meant a mishmash of bogus pre-history founded on the early surmises of Comparative Philology; and by 'desire to see the bones' he meant a demand to see the workings and the proofs that led to these theories. By 'the soup' I mean the story as it is served up by its author or teller, and by 'the bones' its sources or material - even when (by rare luck) those can be with certainty discovered. But I do not, of course, forbid criticism of the soup as soup.

\footnotetext{
${ }^{63}$ Popular Tales from the Norse, p. xviii
} 
Afirmações desse tipo podem expressar (em abreviação indevida) algum elemento de verdade; mas elas não são verdadeiras num sentido de estória de fadas, não são verdadeiras em arte ou literatura. É precisamente o colorido, a atmosfera, os detalhes individuais inclassificáveis de uma estória, e acima de tudo o propósito geral que informa com vida os $\operatorname{ossos}^{64}$ não-dissecados da trama, que realmente contam. O Rei Lear de Shakespeare não é o mesmo que a estória de Layamon em seu Brut. Ou, para tomar o caso extremo de Chapeuzinho Vermelho: é meramente de interesse secundário que as versões recontadas dessa estória, nas quais a garotinha é salva por lenhadores, sejam diretamente derivadas da estória de Perrault, na qual ela é comida pelo lobo. A coisa realmente importante é que a versão posterior tem um final feliz (mais ou menos, e se não prantearmos a avó demais), e que a versão de Perrault não tinha. E essa é uma diferença muito profunda, à qual retornarei.

Claro, eu não nego, pois sinto fortemente, a fascinação do desejo de destrinchar a história intrincadamente emaranhada e ramificada dos galhos na Árvore das Estórias. Ela está proximamente ligada ao estudo dos filólogos sobre o embaraçado tecido da Língua, do qual eu conheço alguns pequenos pedaços. Mas mesmo em relação à língua me parece que a qualidade e aptidões essenciais de uma dada língua num momento vivo são mais importantes de capturar e muito mais difíceis de tornar explícitas do que sua história linear. Pois com relação às estórias de fadas, sinto que é mais interessante, e também de seu jeito mais difícil, considerar o que elas são, o que elas se tornaram para nós, e que valores os longos processos alquímicos do tempo produziram nelas. Nas palavras de Dasent, eu diria: "Temos de ficar satisfeitos com a sopa que é colocada diante de nós, e não desejar ver os ossos do boi com os quais ela foi preparada". ${ }^{65}$ Embora, de forma bastante estranha, Dasent com "sopa" quisesse dizer uma mixórdia de pré-história falsa fundada nas inferências iniciais da Filologia Comparativa; e com “desejo de ver os ossos" ele quisesse dizer uma exigência de ver as elaborações e as provas que levaram a essas teorias. Com "a sopa" quero dizer a estória como é servida por seu autor ou contador, e com "os ossos" suas fontes ou material - mesmo quando (por rara sorte) esses podem ser com certeza descobertos. Mas eu não proíbo, é claro, a crítica da sopa enquanto sopa.

\footnotetext{
${ }^{64}$ É importante manter na tradução a literalidade da metáfora dos ossos porque ela é recorrente, como veremos mais abaixo. Reaparece aqui a preocupação tolkieniana com os estragos que o método analítico tradicional pode causar à apreciação das estórias de fadas. (N. do T.)
} 
I shall therefore pass lightly over the question of origins. I am too unlearned to deal with it in any other way; but it is the least important of the three questions for my purpose, and a few remarks will suffice. It is plain enough that fairy-stories (in wider or in narrower sense) are very ancient indeed. Related things appear in very early records; and they are found universally, wherever there is language. We are therefore obviously confronted with a variant of the problem that the archaeologist encounters, or the comparative philologist: with the debate between independent evolution (or rather invention) of the similar; inheritance from a common ancestry; and diffusion at various times from one or more centres. Most debates depend on an attempt (by one or both sides) at over-simplification; and I do not suppose that this debate is an exception. The history of fairy-stories is probably more complex than the physical history of the human race, and as complex as the history of human language. All three things: independent invention, inheritance, and diffusion, have evidently played their part in producing the intricate web of Story. It is now beyond all skill but that of the elves to unravel it. ${ }^{66}$ Of these three invention is the most important and fundamental, and so (not surprisingly) also the most mysterious. To an inventor, that is to a storymaker, the other two must in the end lead back. Diffusion (borrowing in space), whether of an artefact or a story, only refers the problem of origin elsewhere. At the centre of the supposed diffusion there is a place where once an inventor lived. Similarly with inheritance (borrowing in time): in this way we arrive at last only at an ancestral inventor. While if we believe that sometimes there occurred the independent striking out of similar ideas and themes or devices, we simply multiply the ancestral inventor but do not in that way the more clearly understand his gift.

Philology has been dethroned from the high place it once had in this court of inquiry. Max Müller's view of mythology as a 'disease of language' can be abandoned without regret. Mythology is not a disease at all, though

\footnotetext{
${ }^{65}$ Popular Tales from the Norse, p. xviii.

${ }^{66}$ Except in particularly fortunate cases; or in a few occasional details. It is indeed easier to unravel a single thread - an incident, a name, a motive - than to trace the history of any picture defined by many threads. For with the picture in the tapestry a new element has come in: the picture is greater than, and not explained by, the sum of the component threads. Therein lies the inherent weakness of the analytic (or 'scientific') method: it finds out much about things that occur in stories, bur little or nothing about their effect in any given story.
} 
Portanto, passarei superficialmente pela questão das origens. Sou demasiadamente pouco instruído para lidar com ela de qualquer outra maneira; mas é a menos importante das três questões para o meu propósito, e umas poucas observações bastarão. Está claro o suficiente que as estórias de fadas (em sentido mais amplo ou mais estreito) são de fato muito antigas. Coisas relacionadas aparecem em registros muito antigos; e elas são encontradas universalmente, onde quer que haja língua. Somos portanto confrontados com uma variante do problema que o arqueólogo, ou o filólogo comparativo, encontra: com o debate entre evolução independente (ou melhor, invenção) de similares; herança de uma ascendência comum; e difusão em vários momentos de um ou mais centros. A maioria dos debates depende de uma tentativa (de um ou ambos os lados) de ultrassimplificação; e eu não suponho que esse debate seja uma exceção. A história das estórias de fadas é provavelmente mais complexa do que a história física da raça humana, e tão complexa quanto a história da linguagem humana. Todas as três coisas, invenção independente, herança e difusão, evidentemente tiveram um papel para produzir a intrincada teia da Estória. Agora está além de toda habilidade que não a dos elfos destrinchá-la. ${ }^{67}$ Dessas três a invenção é a mais importante e fundamental, e portanto (não surpreendentemente) também a mais misteriosa. A um inventor, ${ }^{68}$ ou seja, a um contador de estórias, as duas outras devem no fim levar. Difusão (empréstimo no espaço), seja de um artefato ou de uma estória, só remete o problema da origem a outro lugar. No centro da suposta difusão há um lugar onde um inventor certa vez viveu. Da mesma forma com herança (empréstimo no tempo): dessa forma nós chegamos finalmente apenas a um inventor ancestral. Ao passo que, se acreditarmos que às vezes ocorreu o aparecimento independente de idéias e temas ou artifícios similares, nós simplesmente multiplicamos o inventor ancestral, mas não dessa forma entendemos mais claramente o seu dom.

A filologia foi destronada do alto posto que antes tinha nessa corte de inquérito. A visão de Max Müller da mitologia como uma "doença da língua" pode ser abandonada sem remorso. A mitologia não é uma doença de forma alguma, embora

\footnotetext{
${ }^{67}$ Exceto em casos particularmente afortunados; ou em poucos detalhes ocasionais. É de fato mais fácil destrinchar um único fio - um incidente, um nome, um motivo - do que traçar a história de qualquer imagem definida por muitos fios. Pois com a imagem na tapeçaria um novo elemento entrou: a imagem é maior do que, e não é explicada por, uma soma dos fios componentes. Aí jaz a fraqueza inerente do método analítico (ou "científico): ele descobre muito sobre coisas que ocorrem nas histórias, mas pouco ou nada sobre o efeito delas em qualquer história dada.

${ }^{68} \mathrm{~A}$ inversão que colocou o objeto indireto na frente, presente no original, é típica do estilo do ensaio e por isso foi preservada. (N. do T.)
} 
it may like all human things become diseased. You might as well say that thinking is a disease of the mind. It would be more near the truth to say that languages, especially modern European languages, are a disease of mythology. But Language cannot, all the same, be dismissed. The incarnate mind, the tongue, and the tale are in our world coeval. The human mind, endowed with the powers of generalisation and abstraction, sees not only green-grass, discriminating it from other things (and finding it fair to look upon), but sees that it is green as well as being grass. But how powerful, how stimulating to the very faculty that produced it, was the invention of the adjective: no spell or incantation in Faerie is more potent. And that is not surprising: such incantations might indeed be said to be only another view of adjectives, a part of speech in a mythical grammar. The mind that thought of light, heavy, grey, yellow, still, swift, also conceived of magic that would make heavy things light and able to fly, turn grey lead into yellow gold, and the still rock into swift water. If it could do the one, it could do the other; it inevitably did both. When we can take green from grass, blue from heaven, and red from blood, we have already an enchanter's power - upon one plane; and the desire to wield that power in the world external to our minds awakes. It does not follow that we shall use that power well upon any plane. We may put a deadly green upon a man's face and produce a horror; we may make the rare and terrible blue moon to shine; or we may cause woods to spring with silver leaves and rams to wear fleeces of gold, and put hot fire into the belly of the cold worm. But in such 'fantasy', as it is called, new form is made; Faerie begins; Man becomes a subcreator.

An essential power of Faerie is thus the power of making immediately effective by the will the visions of 'fantasy'. Not all are beautiful or even wholesome, nor at any rate the fantasies of fallen Man. And he has stained the elves who have this power (in verity or fable) with his own stain. This aspect of 'mythology' - subcreation, rather than either representation or symbolic interpretation of the beauties and terrors of me world - is, I think, too little considered. Is that because it is seen rather in 
possa, como todas as coisas humanas, ficar adoentada. Você poderia também ${ }^{69}$ dizer que o pensamento é uma doença da mente. Estaria mais perto da verdade dizer que as línguas, em especial as línguas européias modernas, são uma doença da mitologia. Mas a língua não pode, mesmo assim, ser ignorada. A mente encarnada, a língua e a estória são no nosso mundo coevas. A mente humana, agraciada com os poderes da generalização e da abstração, vê não apenas grama-verde, discriminando-a de outras coisas (e achando-a bela de contemplar), mas vê que é verde assim como é grama. Mas quão poderosa, quão estimulante para a própria faculdade que a produziu, foi a invenção do adjetivo: nenhum feitiço ou encantamento em Feéria é mais potente. E isso não é surpreendente: tais encantamentos poderiam de fato ser considerados apenas outra visão dos adjetivos, uma classe de palavras numa gramática mítica. A mente que pensou em leve, pesado, cinza, amarelo, parado, veloz também concebeu magia que tornaria as coisas pesadas leves e capazes de voar, transformaria chumbo cinza em ouro amarelo, e a pedra parada em água veloz. Se podia fazer uma coisa, podia fazer a outra: inevitavelmente fez ambas. Quando podemos tomar o verde da grama, o azul do céu e o vermelho do sangue, temos já um poder de encantador - sobre um plano; e o desejo de empunhar esse poder no mundo externo às nossas mentes desperta. Não se segue dai ${ }^{70}$ que usaremos esse poder bem em qualquer plano. Podemos pôr um verde mortal no rosto de um homem e produzir um horror; podemos fazer a rara e terrível lua azul brilhar; ou podemos fazer com que bosques vicejem com folhas prateadas ou que carneiros usem velos de ouro, e colocar fogo quente na barriga da serpente fria. Mas em tal "fantasia", como é chamada, nova forma é criada; Feéria começa; o Homem torna-se um sub-criador. ${ }^{71}$

Um poder essencial de Feéria é, assim, o poder de tornar imediatamente efetivas pela vontade as visões da "fantasia". Nem todas são belas ou mesmo saudáveis, não de qualquer forma as fantasias do Homem caído. E ele manchou os elfos que têm esse poder (em verdade ou em fábula) com sua própria mancha. Esse aspecto da "mitologia" - sub-criação, em vez de representação ou interpretação simbólica das belezas e terrores do mundo - é, acho, demasiado pouco considerado. Isso é porque ele é visto mais em

\footnotetext{
${ }^{69}$ Não resisti à brincadeira etimológica ao traduzir as well por também, mas creio que sentido e forma se casam de forma admirável nesse contexto. (N. do T.)

${ }^{70}$ Ao acrescentar o "daî" torna-se possível manter a conotação original do verbo follows, "segue". (N. do T.)

${ }^{71}$ Embora o uso do hífen em "sub-criador" vá contra o costume em português, preferi mantê-lo porque ele ressalta o traço acessório do prefixo - o principal é o papel criador do ser humano, nesse contexto, e só depois o fato de que essa capacidade é subordinada à Criação divina maior. (N. do T.)
} 
Faerie than upon Olympus? Because it is thought to belong to the 'lower mythology' rather than to the 'higher'? There has been much debate concerning the relations of these things, of folk-tale and myth; but, even if there had been no debate, the question would require some notice in any consideration of origins, however brief.

At one time it was a dominant view that all such matter was derived from 'naturemyths'. The Olympians were personifications of the sun, of dawn, of night, and so on, and all the stories told about them were originally myths (allegories would have been a better word) of the greater elemental changes and processes of nature. Epic, heroic legend, saga, then localised these stories in real places and humanised them by attributing them to ancestral heroes, mightier than men and yet already men. And finally these legends, dwindling down, became folk-tales, Marchën, fairy-stories - nursery-tales.

That would seem to be the truth almost upside down. The nearer the so-called 'nature-myth', or allegory of the large processes of nature, is to its supposed archetype, the less interesting it is, and indeed the less is it of a myth capable of throwing any illumination whatever on the world. Let us assume for the moment, as this theory assumes, that nothing actually exists corresponding to the 'gods' of mythology: no personalities, only astronomical or meteorological objects. Then these natural objects can only be arrayed with a personal significance and glory by a gift, the gift of a person, of a man. Personality can only be derived from a person. The gods may derive their colour and beauty from the high splendours of nature, but it was Man who obtained these for them, abstracted them from sun and moon and cloud; their personality they get direct from him; the shadow or flicker of divinity that is upon them they receive through rum from me invisible world, the Supernatural. There is no fundamental distinction between the higher and lower mythologies. Their peoples live, if they live at all, by the same life, just as in the mortal world do kings and peasants.

Let us take what looks like a clear case of Olympian nature-myth: the Norse god Thórr. His name is Thunder, of which Thórr is the Norse form; and it is not difficult to interpret his hammer, Miöllnir, as lightning. Yet Thórr has (as far as our late records go) a very marked character, or personality, which cannot be 
Feéria do que no Olimpo? Porque se pensa que ele pertence à "mitologia inferior" mais que à "superior"? Tem havido muito debate acerca das relações dessas coisas, do conto folclórico e do mito; mas mesmo se não houvesse debate, a questão exigiria alguma nota em qualquer consideração de origens, ainda que breve.

Em certa época era a visão dominante que toda matéria do tipo era derivada de “mitos da natureza”. Os Olímpicos eram personificações do sol, da aurora, da noite, e assim por diante, e todas as estórias contadas sobre eles eram originalmente mitos (alegorias teria sido uma palavra melhor) das mudanças e processos elementais maiores da natureza. Épico, lenda heróica, saga, localizavam então essas estórias em lugares reais e as humanizavam ao atribuí-las a heróis ancestrais, mais poderosos que homens e contudo já homens. E finalmente essas lendas, diminuindo, se tornavam contos folclóricos, Märchen, estórias de fadas - contos de ninar.

Essa pareceria ser a verdade quase de ponta-cabeça. Quanto mais perto o assim chamado "mito da natureza", ou alegoria dos grandes processos da natureza, está de seu suposto arquétipo, menos interessante ele é, e de fato menos é um mito capaz de lançar qualquer iluminação que seja sobre o mundo. Vamos assumir para o momento, como essa teoria assume, que nada realmente existe de correspondente aos "deuses" da mitologia: nenhuma personalidade, apenas objetos astronômicos ou meteorológicos. Então esses objetos naturais podem apenas ser adornados com um significado e uma glória pessoal por um dom, um dom de uma pessoa, de um homem. Personalidade só pode ser derivada de uma pessoa. Os deuses podem derivar sua cor e beleza dos altos esplendores da natureza, mas foi o Homem que obteve essas para eles, abstraiu-as ${ }^{72}$ de sol e lua e nuvem; sua personalidade eles a obtêm diretamente dele; a sombra ou brilho de divindade que está sobre eles, eles a recebem através dele do mundo invisível, o Sobrenatural. Não há distinção fundamental entre as mitologias superiores e inferiores. Seus povos vivem, se vivem de algum modo, pela mesma vida, tal como no mundo mortal vivem reis e camponeses.

Tomemos o que parece um caso claro de mito da natureza olímpico: o deus nórdico Thórr. Seu nome é Trovão, de que Thórr é a forma nórdica; e não é difícil interpretar seu martelo, Miöllnir, como relâmpago. Contudo, Thórr tem (até onde nossos registros tardios vão) um caráter, ou personalidade, muito marcados, que não podem ser

\footnotetext{
72 "Abstrair" é aqui usado tanto em sentido etimológico quanto corrente: "tirar de" e também desenvolver uma abstração a partir de um fato concreto. Nenhuma outra palavra consegue cumprir ambas as funções. (N. do T.)
} 
found in thunder or in lightning, even though some details can, as it were, be related to these natural phenomena: for instance, his red beard, his loud voice and violent temper, his blundering and smashing strength. None the less it is asking a question without much meaning, if we inquire: Which came first, nature-allegories about personalized thunder in the mountains, splitting rocks and trees; or stories about an irascible, not very clever, red-beard farmer, of a strength beyond common measure, a person (in all but mere stature) very like the Northern farmers, the boendr by whom Thórr was chiefly beloved? To a picture of such a man Thórr may be held to have 'dwindled', or from it the god may be held to have been enlarged. But I doubt whether either view is right - not by itself, not if you insist that one of these things must precede the other. It is more reasonable to suppose that the farmer popped up in the very moment when Thunder got a voice and face; that there was a distant growl of thunder in the hills every time a storyteller heard a farmer in a rage.

Thórr must, of course, be reckoned a member of the higher aristocracy of mythology: one of the rulers of the world. Yet the tale that is told of him in Thrymskvitha (in the Elder Edda) is certainly just a fairy-story. It is old, as far as Norse poems go, but that is not far back (say AD 900 or a little earlier, in this case). But there is no real reason for supposing that this tale is 'unprimitive', at any rate in quality: that is, because it is of folk-tale kind and not very dignified. If we could go backwards in time, the fairy-story might be found to change in details, or to give way to other tales. But there would always be a 'fairy-tale' as long as there was any Thórr. When the fairy-tale ceased, there would be just thunder, which no human ear had yet heard.

Something really 'higher' is occasionally glimpsed in mythology: Divinity, the right to power (as distinct from its possession), the due of worship; in fact 'religion'. Andrew Lang said, and is by some still commended for saying, ${ }^{73}$ that mythology and religion (in the strict sense of that word) are two distinct things that have

\footnotetext{
${ }^{73}$ For example, by Christopher Dawson in Progress and Religion.
} 
encontrados no trovão ou no relâmpago, mesmo que alguns detalhes possam, de certa forma, ser relacionados a esses fenômenos naturais: por exemplo, sua barba vermelha, sua voz forte e seu temperamento violento, sua força desastrada e esmagadora. Mesmo assim, é fazer uma pergunta sem muito significado se inquirirmos: o que veio primeiro, alegorias da natureza sobre trovão personalizado nas montanhas, rachando pedras e árvores; ou estórias sobre um fazendeiro irascível, não muito esperto, de barba ruiva, de uma força além da medida comum, uma pessoa (em tudo salvo na mera estatura) muito semelhante aos fazendeiros do Norte, os beendr ${ }^{74}$ por quem Thórr era especialmente amado? Para uma imagem de tal homem pode-se sustentar que Thórr tenha "diminuído", ou dela pode-se sustentar que o deus tenha sido aumentado. Mas duvido que qualquer uma das visões esteja certa - não por si só, não se você insistir que uma dessas coisas deve preceder a outra. É mais razoável supor que o fazendeiro apareceu no exato momento em que Trovão ganhou uma voz e um rosto; que havia um distante rosnado de trovão nas colinas toda vez que um contador de estórias ouvia um fazendeiro com raiva.

Thórr deve, é claro, ser considerado um membro da aristocracia superior da mitologia: um dos governantes do mundo. Contudo, a estória que é contada dele em Thrymskvitha (no Edda Antigo) é certamente apenas uma estória de fadas. É velha, até onde vão os poemas nórdicos, mas isso não é muita coisa (digamos, 900 d.C., ou um pouco anterior, nesse caso). Mas não há nenhuma razão real para supor que essa estória seja "não-primitiva", de qualquer modo em qualidade: isto é, porque ela é do tipo folclórico e não muito dignificada. Se pudéssemos recuar no tempo, a estória de fadas poderia se mostrar mudada em detalhes, ou dar lugar a outras estórias. Mas sempre haveria uma "estória de fadas" enquanto houvesse algum Thórr. Quando a estória de fadas cessasse, haveria apenas trovão, que nenhum ouvido humano ainda tinha escutado.

Algo realmente "superior" é ocasionalmente vislumbrado na mitologia: Divindade, o direito ao poder (enquanto distinto de sua posse), a adoração devida ${ }^{75} \mathrm{de}$ fato "religião". Andrew Lang disse, e é por alguns ainda elogiado por ter dito, ${ }^{76}$ que mitologia e religião (no sentido estrito dessa palavra) são duas coisas distintas que se

\footnotetext{
${ }^{74}$ No singular bóndi, "fazendeiro, camponês" em islandês antigo. A idéia é de que alguém que está "preso" (bound, como se diz em inglês) à terra. (N. do T.)

${ }^{75} \mathrm{~A}$ tradução não tem a preposição, mas due tem algo de particípio, o que justifica a opção feita aqui. (N. do T.)

${ }^{76}$ Por exemplo, por Christopher Dawson em Progress and Religion.
} 
become inextricably entangled, though mythology is in itself almost devoid of religious significance. ${ }^{77}$ Yet these things have in fact become entangled or maybe they were sundered long ago and have since groped slowly, through a labyrinth of error, through confusion, back towards re-fusion. Even fairy-stories as a whole have three faces: the Mystical towards the Supernatural; the Magical towards Nature; and the Mirror of scorn and pity towards Man. The essential face of Faerie is the middle one, the Magical. But the degree in which the others appear (if at all) is variable, and may be decided by the individual story-teller. The Magical, the fairy-story, may be used as a Mirour de l'Omme; and it may (but not so easily) be made a vehicle of Mystery. This at least is what George MacDonald attempted, achieving stories of power and beauty when he succeeded, as in The Golden Key (which he called a fairy-tale); and even when he partly failed, as in Lilith (which he called a romance).

For a moment let us return to the 'Soup' that I mentioned above. Speaking of the history of stories and especially of fairy-stories we may say that the Pot of Soup, the Cauldron of Story, has always been boiling, and to it have continually been added new bits, dainty and undainty. For this reason, to rake a casual example, the fact that a story resembling the one known as The Goosegirl (Die Gänsemagd in Grimm) is told in the thirteenth century of Bertha Broadfoot, mother of Charlemagne, really proves nothing either way: neither that the story was (in the thirteenth century) descending from Olympus or Asgard by way of an already legendary king of old, on its way to become a Hausmärchen; nor that it was on its way up. The Story is found to be widespread, unattached to the mother of Charlemagne or to any historical character. From this fact by itself we certainly cannot deduce that it is nor true of Charlemagne's mother,

\footnotetext{
77 This is borne out by the more careful and sympathetic study of 'primitive' peoples: that is, peoples still living in an inherited paganism who are not, as we say, civilised. The hasty survey finds only their wilder tales; a closer examination finds their cosmological myths; only patience and inner knowledge discovers their philosophy and religion: the truly worshipful, of which the 'gods' are not necessarily an embodiment at all, or only in a variable measure (often decided by the individual).
} 
tornaram inextricavelmente entrelaçadas, embora a mitologia seja em si mesma quase desprovida de significância religiosa. ${ }^{78}$

Contudo, essas coisas de fato se tornaram entrelaçadas - ou talvez elas tenham sido separadas há muito e tenham desde então tateado vagarosamente, através de um labirinto de erro, de confusão, de volta à re-fusão. Mesmo as estórias de fadas como um todo têm três faces: a Mística voltada para o Sobrenatural; a Mágica voltada para a Natureza; e o Espelho de escárnio e pena voltado para o Homem. A face essencial de Feéria é a do meio, a Mágica. Mas o grau em que as outras aparecem (se aparecem) é variável, e pode ser decidido pelo contador de estórias individual. A Mágica, a estória de fadas, pode ser usada como um Mirour de l'Omme; ${ }^{79}$ e pode (mas não tão facilmente) se tornar um veículo do Mistério. Isso pelo menos é o que George MacDonald tentou, conseguindo estórias de poder e beleza quando teve sucesso, como em $A$ Chave Dourada (que ele chamava de conto de fadas); e mesmo quando falhou parcialmente, como em Lilith (que ele chamava de romance). ${ }^{80}$

Por um momento, retornemos à "Sopa" que eu mencionei acima. Falando da história das estórias e especialmente da das estórias de fadas, podemos dizer que a Panela de Sopa, o Caldeirão da Estória, sempre esteve fervendo, e a ele foram continuamente adicionados novos ingredientes, refinados e não-refinados. Por essa razão, para tomar um exemplo casual, o fato de que uma estória que lembra a conhecida como A Garota Ganso (Die Gänsemagd em Grimm) seja contada no século XIII sobre Bertha Pé-largo, mãe de Carlos Magno, realmente não prova nada para nenhum lado: nem que a estória (no século XIII) estava descendo do Olimpo ou de Asgard por meio de um já legendário rei de outrora, no caminho de se tornar uma Hausmärchen; nem que estava no caminho de subida. A estória se mostra amplamente distribuída, não-ligada à mãe de Carlos Magno ou a qualquer outra personagem histórica. Desse fato em si mesmo nós certamente não podemos deduzir que não seja verdadeira em relação à mãe

\footnotetext{
${ }^{78}$ Isso é corroborado pelo estudo mais cuidadoso e compreensivo de povos "primitivos": isto é, de povos ainda vivendo num paganismo herdado, que não são, como dizemos, civilizados. A busca apressada encontra apenas seus contos mais selvagens; um exame mais próximo encontra seus mitos cosmológicos; só a paciência e o conhecimento íntimo descobrem sua filosofia e religião: o que é realmente adorado, do qual os "deuses" não são necessariamente uma incorporação, ou apenas o são numa medida variável (freqüentemente decidida pelo indivíduo).

${ }^{79}$ Não é à toa que o francês da expressão (“espelho do homem”) soa canhestro: esse é o título de uma obra escrita em dialeto anglo-normando pelo inglês Gower, o mesmo da citação sobre Feéria do começo do ensaio, no fim do século XIV. (N. do T.)

${ }^{80}$ Infelizmente a diferença entre novel e romance, que aqui é importante para Tolkien, fica borrada em português moderno, embora a distinção provavelmente fosse parecida séculos atrás com a que existe em inglês. (N. do T.)
} 
though that is the kind of deduction that is most frequently made from that kind of evidence. The opinion that the story is not true of Bertha Broadfoot must be founded on something else: on features in the Story which the critic's philosophy does nor allow to be possible in 'real life', so that he would actually disbelieve the tale, even if it were found nowhere else; or on the existence of good historical evidence that Bertha's actual life was quite different, so that he would disbelieve the tale, even if his philosophy allowed that it was perfectly possible in 'real life'. No one, I fancy, would discredit a story that the Archbishop of Canterbury slipped on a banana skin merely because he found that a similar comic mishap had been reported of many people, and especially of elderly gentlemen of dignity. He might disbelieve the story, if he discovered that in it an angel (or even a fairy) had warned the Archbishop that he would slip if he wore gaiters on a Friday. He might also disbelieve the story, if it was stated to have occurred in the period between, say, 1940 and 1945. So much for that. It is an obvious point, and it has been made before; but I venture to make it again (although it is a little beside my present purpose), for it is constantly neglected by those who concern themselves with the origins of tales.

But what of the banana skin? Our business with it really only begins when it has been rejected by historians. It is more useful when it has been thrown away.

The historian would be Likely to say that the banana skin story 'became attached to the Archbishop', as he does say on fair evidence that 'the Goosegirl Märchen became attached to Bertha'. That way of putting it is harmless enough, in what is commonly known as 'history'. But is it really a good description of what is going on and has gone on in the history of story-making? I do not think so. I think it would be nearer the truth to say that the Archbishop became attached to the banana skin, or that Bertha was turned into the Goosegirl. Better still: I would say that Charlemagne's mother and the Archbishop were put into the Pot, in fact got into the Soup. They were just new bits added to the stock. A considerable honour, for in that soup were many things older, more potent, more beautiful, comic, or terrible than they were in themselves (considered simply as figures of history). It seems fairly plain that Arthur, once historical (but perhaps as such not of great importance), was also put into the Pot. There he was boiled for a long 
de Carlos Magno, embora esse seja o tipo de dedução feito mais freqüentemente desse tipo de evidência. A opinião de que a estória não é verdadeira em relação a Bertha Pélargo deve ser fundamentada em algo mais: em características da estória que a filosofia do crítico não permite serem possíveis na "vida real", de forma que ele de fato não acreditaria na estória, mesmo se ela não fosse encontrada em nenhum outro lugar; ou na existência de boas evidências históricas de que a vida real de Bertha tenha sido bem diferente, de forma que ele não acreditaria na estória, mesmo que sua filosofia permitisse que ela fosse perfeitamente possível na "vida real”. Ninguém, imagino, deixaria de acreditar na estória de que o Arcebispo da Cantuária escorregou numa casca de banana meramente porque descobriu que um acidente cômico similar tinha sido relatado sobre muitas pessoas, e especialmente sobre cavalheiros idosos e proeminentes. A pessoa poderia não acreditar na estória se descobrisse que um anjo (ou mesmo uma fada) tinha avisado o Arcebispo de que iria escorregar se usasse polainas numa sextafeira. Ela poderia também não acreditar na estória caso se afirmasse que ela ocorreu no período entre, digamos, 1940 e 1945. Já é suficiente. É um argumento óbvio, e foi usado antes; mas arrisco usá-lo outra vez (embora esteja um pouco além do meu propósito presente), pois ele é constantemente negligenciado por aqueles que se preocupam com as origens de contos.

Mas e quanto à casca de banana? Nossa relação com ela realmente começa apenas quando é rejeitada pelos historiadores. É mais útil quando é jogada fora. O historiador provavelmente diria que a estória da casca de banana "ficou ligada ao Arcebispo", como realmente diz com boas evidências que "a Marchën da Garota Ganso ficou ligada a Bertha". Mas essa é realmente uma boa descrição do que está acontecendo e do que aconteceu na história da criação de estórias? Acho que não. Acho que estaria mais perto da verdade dizer que o Arcebispo ficou ligado à casca de banana, ou que Bertha foi transformada na Garota Ganso. Melhor ainda: eu diria que a mãe de Carlos Magno e o Arcebispo foram colocados na Panela, entraram de fato na Sopa. Foram só novos ingredientes adicionados ao caldo. Uma honra considerável, pois naquela sopa estavam muitas coisas mais velhas, mais potentes, mais belas, cômicas ou terríveis do que eles eram em si mesmos (considerados simplesmente como figuras da história).

Parece razoavelmente claro que Arthur, antes histórico (mas talvez como tal não de grande importância), também foi colocado na Panela. Lá ele cozinhou por um longo 
time, together with many other older figures and devices, of mythology and Faerie, and even some other stray bones of history (such as Alfred's defence against the Danes), until he emerged as a King of Faerie. The situation is similar in the great Northern 'Arthurian' court of the Shield-Kings of Denmark, the Scyldingas of ancient English tradition. King Hrothgar and his family have many manifest marks of true history, far more than Arthur; yet even in the older (English) accounts of them they are associated with many figures and events of fairy-story: they have been in the Pot. But I refer now to the remnants of the oldest recorded English tales of Faerie (or its borders), in spite of the fact that they are little known in England, not to discuss the turning of the bear-boy into the knight Beowulf, or to explain the intrusion of the ogre Grendel into the royal hall of Hrothgar. I wish to point to something else that these traditions contain: a singularly suggestive example of the relation of the 'fairy-tale element' to gods and kings and nameless men, illustrating (I believe) the view that this element does not rise or fall, but is there, in the Cauldron of Story, waiting for the great figures of Myth and History, and for the yet nameless He or She, waiting for the moment when they are cast into the simmering stew, one by one or all together, without consideration of rank ot precedence.

The great enemy of King Hrothgar was Froda, King of the Heathobards. Yet of Hrothgar's daughter Freawaru we hear echoes of a strange tale - not a usual one in Northern heroic legend: the son of the enemy of her house, Ingeld son of Froda, fell in love Will her and wedded her, disastrously. But that is extremely interesting and significant. In the background of the ancient feud looms the figure of that god whom the Norsemen called Frey (the Lord) or Yngvi-frey, and the Angles called Ing: a god of the ancient Northern mythology (and religion) of Fertility and Corn. The enmity of the royal houses was connected with the sacred site of a cult of that religion. Ingeld and his father bear names belonging to it. Freawaru herself is named 'Protection of the Lord (of Frey)'. Yet one of the chief things told later (in Old Icelandic) about Frey is the story in which he falls in love from afar with the daughter of the enemies of the gods, Gerdr, daughter of the giant Gymir, and weds her. Does this prove that Ingeld and Freawaru, or their love, are 'merely mythical'? I think not. 
tempo, junto com muitas outras figuras e emblemas ${ }^{81}$ mais antigos, da mitologia e de Feéria, e mesmo com alguns outros ossos perdidos da história (tais como a defesa de Alfred contra os daneses), até que ele emergiu como um Rei de Feéria. A situação é similar na grande corte "arturiana" nortista dos Reis do Escudo da Dinamarca, os Scyldingas da antiga tradição inglesa. O rei Hrothgar e sua família têm muitas marcas manifestas de história verdadeira, bem mais que Arthur; contudo, mesmo nos mais antigos relatos (ingleses) sobre eles, são associados com muitas figuras e eventos de estória de fadas: eles estiveram na Panela. Mas me refiro agora aos restos das mais antigas estórias inglesas registradas de Feéria (ou de suas fronteiras), apesar do fato de que elas são pouco conhecidas na Inglaterra, não para discutir a transformação do menino-urso no cavaleiro Beowulf, ou para explicar a intrusão do ogro Grendel no salão real de Hrothgar. Desejo apontar algo mais que essas tradições contêm: um exemplo singularmente sugestivo da relação do "elemento de conto de fadas" com deuses e reis e homens anônimos, ilustrando (acredito eu) a visão de que esse elemento não se eleva ou cai, mas está lá, no Caldeirão da Estória, esperando pelas grandes figuras do Mito e da História, e pelos ainda anônimos Ele ou Ela, esperando o momento em que eles são lançados no caldo borbulhante, um por um ou todos juntos, sem consideração de classe ou precedência.

O grande inimigo do rei Hrothgar era Froda, rei dos Hatobardos. Contudo, sobre a filha de Hrothgar, Freawaru, ouvimos ecos de uma estória estranha - não usual na lenda heróica do Norte: o filho do inimigo de sua casa, Ingeld, filho de Froda, se apaixonou por ela e a desposou, desastrosamente. Mas isso é extremamente interessante e significativo. No pano de fundo da antiga contenda se ergue a figura do deus que os nórdicos chamavam de Frey (o Senhor) ou Yngvi-Frey, e que os anglos chamavam de Ing: um deus da antiga mitologia (e religião) nórdica da Fertilidade e do Trigo. A inimizade das casas reais estava ligada ao local sagrado de um culto dessa religião. Ingeld e seu pai carregam nomes pertencentes a ele. A própria Freawaru é denominada "Proteção do Senhor (de Frey)". Contudo, uma das principais coisas contadas mais tarde (em islandês antigo) sobre Frey é a estória em que ele se apaixona à distância pela filha dos inimigos dos deuses, Gerdr, filha do gigante Gymir, e a desposa. Isso prova que Ingeld e Freawaru, ou o amor deles, são "meramente míticos”? Acho que não. A

\footnotetext{
${ }^{81}$ A conexão heráldica aqui é intencional, como a que existe em device em inglês. Nada mais adequado, já que Tolkien está se referindo a imagens icônicas - arquétipos, na linguagem psicanalítica muito em voga décadas atrás. (N. do T.)
} 
History often resembles 'Myth', because they are both ultimately of the same stuff. If indeed Ingeld and Freawaru never lived, or at least never loved, then it is ultimately from nameless man and woman that they get their tale, or rather into whose tale they have entered. They have been put into the Cauldron, where so many potent things lie simmering agelong on the fire, among them Love-at-firstsight. So too of the god. If no young man had ever fallen in love by chance meeting with a maiden, and found old enmities to stand between him and his love, then the god Frey would never have seen Gerdr he giant's daughter from the highseat of Odin. But if we speak of a Cauldron, we must not wholly forget the Cooks. There are many things in the Cauldron, but the Cooks do not dip in the ladle quite blindly. Their selection is important. The gods are after all gods, and it is a matter of some moment what stories are told of them. So we must freely admit that a tale of love is more likely to be told of a prince in history, indeed is more likely actually to happen in an historical family whose traditions are those of golden Frey and the Vanir, rather than those of Odin the Goth, the Necromancer, glutter of the crows, Lord of the Slain. Small wonder that spell means both a story told, and a formula of power over living men.

But when we have done all that research - collection and comparison of the tales of many lands - can do; when we have explained many of the elements commonly found embedded in fairy-stories (such as stepmothers, enchanted bears and bulls, cannibal witches, taboos on names, and the like) as relics of ancient customs once practised in daily life, or of beliefs once held as beliefs and not as 'fancies' - there remains still a point too often forgotten: that is the effect produced now by these old things in the stories as they are.

For one thing they are now old, and antiquity has an appeal in itself. The beauty and horror of The Juniper Tree (Von dem Machandelboom), with its exquisite and tragic beginning, the abominable cannibal stew, the gruesome bones, the gay and vengeful bird-spirit coming out of a mist that rose from the tree, has remained with me since childhood; and yet always the chief flavour of that tale lingering in the 
história freqüentemente lembra o mito, porque ambos são em última instância do mesmo estofo. ${ }^{82}$ Se de fato Ingeld e Freawaru nunca viveram, ou pelo menos nunca amaram, então é em última instância do homem e mulher anônimos que eles ganharam sua estória, ou melhor, em cuja estória entraram. Foram colocados no Caldeirão, onde tantas coisas potentes jazem borbulhando por eras no fogo, entre elas Amor-à-primeiravista. Assim também para o deus. Se nenhum jovem jamais tivesse se apaixonado num encontro casual por uma donzela, e não tivesse descoberto velhas inimizades a se por entre ele e seu amor, então o deus Frey nunca teria visto Gerdr, a filha do gigante, do assento elevado de Odin. Mas, se falamos de um Caldeirão, não devemos esquecer totalmente os Cozinheiros. Há muitas coisas no Caldeirão, mas os Cozinheiros não mergulham a concha nele cegamente. A seleção deles é importante. Os deuses são afinal deuses, e é matéria de certa importância quais estórias são contadas deles. Então devemos admitir livremente que uma estória de amor é mais provável de ser contada de um príncipe da história, de fato é mais provável de realmente acontecer numa família histórica cujas tradições são as do Dourado Frey e dos Vanir, do que as de Odin, o Godo, o Necromante, saciador dos corvos, Senhor dos Mortos. Pouco é de se admirar que $\operatorname{spell}^{83}$ signifique tanto uma estória contada quanto uma fórmula de poder sobre homens viventes.

Mas quando fazemos tudo o que a pesquisa - coleta e comparação dos contos de muitas terras - pode fazer; quando explicamos muitos dos elementos comumente achados incrustados em estórias de fadas (tais como madrastas, ursos e touros encantados, bruxas canibais, tabus sobre nomes e coisas do tipo) como relíquias de costumes antes praticados na vida diária, ou de crenças antes tomadas como crenças e não como "fantasias" - resta ainda um ponto com demasiada freqüência esquecido: isto é, o efeito produzido agora por essas coisas velhas nas estórias como elas são.

Para começar, elas são agora velhas, e a antigüidade tem um apelo em si mesma. A beleza e o horror de O Junípero (Von dem Machandelboom), com seu magistral e trágico começo, o abominável cozido canibal, os ossos asquerosos, o alegre e vingativo espírito-pássaro saindo de uma névoa que se levantara da árvore, permaneceu comigo desde a infância; e contudo sempre o principal sabor daquele conto que permanece na

\footnotetext{
${ }^{82}$ Além da conservação da relação entre os significantes, é relativamente pequena a distância semântica entre "matéria-prima" ou "material" e "recheio, conteúdo". (N. do T.)

${ }^{83} \mathrm{O}$ primeiro sentido de spell que Tolkien menciona é, claro, o presente em gospel. Eis um daqueles momentos em que o sistema de equivalências sobre o qual repousa a tradução é seriamente esgarçado, e o único caminho é usar a palavra no idioma original.
} 
memory was not beauty or horror, but distance and a great abyss of time, not measurable even by twe tusend Johr. Without the stew and the bones - which children are now too often spared in mollified versions of Grimm $^{84}$ - that vision would largely have been lost. J do not think I was harmed by the horror in the fairy-tale setting, out of whatever dark beliefs and practices of the past it may have come. Such stories have now a mythical or total (unanalysable) effect, an effect quite independent of the findings of Comparative Folk-lore, and one which it cannot spoil or explain; they open a door on Other Time, and if we pass through, though only for a moment, we stand outside our own time, outside Time itself, maybe.

If we pause, not merely to note that such old elements have been preserved, but to think how they have been preserved, we must conclude, I think, that it has happened, often if not always, precisely because of this literary effect. It cannot have been we, or even the brothers Grimm, that first felt it. Fairy-stories are by no means rocky matrices out of which the fossils cannot be prised except by an expert geologist. The ancient elements can be knocked out, or forgotten and dropped out, or replaced by other ingredients with the greatest ease: as any comparison of a story with closely related variants will show. The things that are there must often have been retained (or inserted) because the oral narrators, instinctively or consciously, felt their literary 'significance'. ${ }^{85}$ Even where a prohibition in a fairy-story is guessed to be derived from some taboo once practised long ago, it has probably been preserved in the later stages of the tale's history because of the great mythical significance of prohibition. A sense of that significance may indeed have lain behind some of the taboos themselves. Thou shalt not - or else thou shalt depart beggared into endless regret. The gentlest 'nursery-tales' know it. Even Peter Rabbit was forbidden a garden, lost his blue coat, and took sick. The Locked Door stands as an eternal Temptation.

\section{CHILDREN}

\footnotetext{
${ }^{84}$ They should not be spared it - unless they are spared the whole story until their digestions are stronger.

${ }^{85}$ See Note B at end.
} 
memória não é a beleza ou o horror, mas a distância e um grande abismo de tempo, não mensuráveis nem mesmo por twe tusend Johr. ${ }^{86}$ Sem o cozido e os ossos - dos quais as crianças são agora com demasiada freqüência poupadas em versões amolecidas de Grimm $^{87}$-, essa visão seria em grande parte perdida. Não acho que eu tenha sido ferido pelo horror no contexto do conto de fadas, seja lá de que crenças e práticas escuras ele possa ter vindo. Tais estórias têm agora um efeito mítico ou total (não analisável) ${ }^{88}$ um efeito bastante independente das descobertas do Folclore Comparativo, e que ele não pode estragar ou explicar; elas abrem uma porta para Outro Tempo, e se atravessarmos, ainda que por um momento, ficamos fora de nosso próprio tempo, fora do Tempo em si, talvez.

Se pararmos, não meramente para notar que tais velhos elementos foram preservados, mas para pensar em como eles foram preservados, devemos concluir, acho, que isso aconteceu com freqüência, se não sempre, precisamente por causa de seu efeito literário. Não podemos ter sido nós, ou mesmo os irmãos Grimm, que primeiro o sentimos. Estórias de fadas não são de forma nenhuma matrizes rochosas das quais os fósseis não podem ser arrancados, a não ser por um geólogo perito. Os elementos antigos podem ser retirados, ou esquecidos e jogados fora, ou repostos por outros ingredientes com a maior facilidade: como mostra qualquer comparação de uma estória com variantes proximamente relacionadas. As coisas que estão lá devem ter sido retidas (ou inseridas) com freqüência porque os narradores orais, instintiva ou conscientemente, sentiram sua "significância" literária. ${ }^{89}$ Mesmo onde se deduz que uma proibição numa estória de fadas é derivada de algum tabu praticado há muito tempo, ela provavelmente foi preservada nos estágios posteriores da história do conto por causa da grande significância mítica da proibição. Uma percepção dessa significância pode, de fato, estar por trás de alguns dos próprios tabus. Tu não farás - ou então tu partirás mendigando em arrependimento sem fim. As mais gentis "estórias de ninar" o sabem. Até Pedro, o Coelho, foi proibido de entrar num jardim, perdeu seu casaco azul e ficou doente. A Porta Trancada permanece uma Tentação eterna.

\section{CRIANÇAS}

\footnotetext{
${ }^{86}$ A frase está em baixo-alemão, ou alemão dialetal, como está todo esse conto recolhido pelos Grimm. (N. do T.)

${ }^{87}$ Elas não deveriam ser poupadas disso - a menos que sejam poupadas da história inteira até que sua digestão seja mais forte.

${ }^{88}$ Mais um capítulo da contenda de Tolkien com os excessos do método analítico. (N. do T.)
} 
I will now turn to children, and so come to the last and most important of the three questions: what, if any, are the values and functions of fairy-stories now? It is usually assumed that children are the natural or the specially appropriate audience for fairy-stories. In describing a fairy-story which they think adults might possibly read for their own entertainment, reviewers frequently indulge in such waggeries as: 'this book is for children from the ages of six to sixty'. But I have never yet seen the puff of a new motor-model that began thus: 'this toy will amuse infants from seventeen to seventy'; though that to my mind would be much more appropriate. Is there any essential connection between children and fairystories? Is there any call for comment, if an adult reads them for himself? Reads them as tales, that is, not studies them as curios. Adults are allowed to collect and study anything, even old theatre-programmes or paper bags.

Among those who still have enough wisdom not to think fairy-stories pernicious, the common opinion seems to be that there is a natural connection between the minds of children and fairy-stories, of the same order as the connection between children's bodies and milk. I think this is an error; at best an error of false sentiment, and one that is therefore most often made by those who, for whatever private reason (such as childlessness), tend to think of children as a special kind of creature, almost a different race, rather than as normal, if immature, members of a particular family, and of the human family at large.

Actually, the association of children and fairy-stories is an accident of our domestic history. Fairy-stories have in the modern lettered world been relegated to the 'nursery', as shabby or old-fashioned furniture is relegated to the playroom, primarily because the adults do nor want it, and do nor mind if it is misused ${ }^{90}$. I It is not the choice of the children which decides this. Children as a class - except in a common lack of experience they are not one - neither like fairy-stories more, nor understand them better than adults do; and no more than they like many other things. They are young and growing, and normally have keen appetites, so the fairy-stories as a rule go down well enough.

\footnotetext{
${ }^{89}$ Ver Nota B no fim

${ }^{90}$ In the case of stories and other nursery lore, there is also another factor. Wealthier families employed women to look after their children, and the stories were provided by these nurses, who were sometimes in touch with rustic and traditional lore forgotten by their 'betters'. It is long since this source dried up, at any rate in England; but it once had some importance. But again there is no proof of the special fitness of children as the recipients of this vanishing 'folk-lore', The nurses might just as well (or better) have been left to choose the pictures and furniture.
} 
Voltar-me-ei agora para as crianças, e então chegarei à última e mais importante das três questões: quais, se existem, são os valores e as funções das estórias de fadas agora? Normalmente se assume que as crianças são a audiência natural ou especialmente apropriada para estórias de fadas. Ao descrever uma estória de fadas que eles acham que os adultos poderiam possivelmente ler para seu próprio entretenimento, os resenhistas freqüentemente se permitem dizer bobagens como: "Este livro é para crianças das idades de seis a sessenta”. Mas eu ainda não vi o anúncio de um novo modelo motorizado que começasse assim: "este brinquedo vai divertir infantes dos dezessete aos setenta anos"; embora isso, para a minha mente, fosse muito mais apropriado. Há alguma conexão essencial entre crianças e estórias de fadas? Há alguma necessidade de comentário, se um adulto as lê para si mesmo? Lê como estórias, isto é, não as estuda como curiosidades. Adultos são liberados para colecionar e estudar qualquer coisa, até velhos programas de teatro ou sacos de papel.

Entre aqueles que ainda têm sabedoria suficiente para não achar as estórias de fadas perniciosas, a opinião comum parece ser a de que há uma conexão natural entre as mentes das crianças e as estórias de fadas, da mesma ordem que a conexão entre os corpos das crianças e o leite. Acho que isso é um erro; na melhor das hipóteses um erro de falso sentimento, e que é portanto com mais freqüência cometido por aqueles que, por qualquer razão privada (tal como a falta de filhos), tendem a pensar nas crianças como um tipo especial de criatura, quase uma raça diferente, e não como membros normais, ainda que imaturos, de uma família particular, e da família humana em geral.

$\mathrm{Na}$ verdade, a associação de crianças e estórias de fadas é um acidente da nossa história doméstica. As estórias de fadas têm sido, no mundo moderno letrado, relegadas ao berçário, assim como a mobília desmazelada e antiquada é relegada ao quarto de brinquedos, primariamente porque os adultos não a querem, e não se importam se ela é maltratada. ${ }^{91}$ Não é a escolha das crianças que decide isso. As crianças como classe - o que elas não são, exceto numa falta comum de experiência - nem gostam mais de estórias de fadas, nem as entendem melhor do que os adultos; e não mais do que elas gostam de muitas outras coisas. Elas são jovens e estão crescendo, e normalmente têm apetites ávidos, então as estórias de fadas via de regra descem suficientemente bem.

\footnotetext{
${ }^{91}$ No caso das estórias e da tradição do berçário, há também outro fator. As famílias mais abastadas empregavam mulheres para cuidar de suas crianças, e as estórias eram contadas por essas amas, que estavam às vezes em contato com tradições rústicas e folclóricas esquecidas por seus "superiores". Há muito que essa fonte secou, pelo menos na Inglaterra; mas já teve alguma importância. Mas, de novo, não
} 
But in fact only some children, and some adults, have any special taste for them; and when they have it, it is not exclusive, not even necessarily dominant. ${ }^{92}$ It is a taste, too, that would not appear, I think, very early in childhood without artificial stimulus; it is certainly one that does nor decrease bur increases with age, if it is innate.

It is true that in recent rimes fairy-stories have usually been written or 'adapted' for children. But so may music be, or verse, or novels, or history, or scientific manuals. It is a dangerous process, even when it is necessary. It is indeed only saved from disaster by the fact that the arts and sciences are not as a whole relegated to the nursery; the nursery and schoolroom are merely given such tastes and glimpses of the adult thing as seem fit for them in adult opinion (often much mistaken). Any one of these things would, if left altogether in the nursery, become gravely impaired. So would a beautiful table, a good picture, or a useful machine (such as a microscope), be defaced or broken, if it were left long unregarded in a schoolroom. Fairy-stories banished in this way, cut off from a full adult art, would in the end be ruined; indeed in so far as they have been so banished, they have been ruined.

The value of fairy-stories is thus not, in my opinion, to be found by considering children in particular. Collections of fairy-stories are, in fact, by nature attics and lumber-rooms, only by temporary and local custom play-rooms. Their contents are disordered, and often battered, a jumble of different dates, purposes, and tastes; but among them may occasionally be found a thing of permanent virtue: an old work of art, not too much damaged, that only stupidity would ever have stuffed away.

Andrew Lang's Fairy Books are not, perhaps, lumber-rooms. They are more like stalls in a rummage-sale. Someone with a duster and a fair eye for things that retain some value has been round the attics and box-rooms. His collections are largely a by-product of his adult study of mythology and folk-lore; but they were made into and presented as books for children. ${ }^{93}$ Some of the reasons that Lang gave are worth considering.

há prova da adequação especial das crianças como receptoras desse "folclore" em desaparecimento. As amas poderiam muito bem (ou até melhor) ser encarregadas de escolher as pinturas e a mobília.

${ }^{92}$ See Note $\mathrm{C}$ at end

${ }^{93}$ By Lang and his helpers. It is nor true of the majority of the contents in their original (or oldest surviving) forms. 
Mas na verdade apenas algumas crianças, e alguns adultos, têm qualquer gosto especial por elas; e quando o têm, ele não é exclusivo, nem mesmo necessariamente dominante. ${ }^{94}$ É um gosto, também, que não aparece, creio eu, muito cedo na infância sem estímulo artificial; e é certamente um que não diminui mas aumenta com a idade, se for inato.

É verdade que em tempos recentes as estórias de fadas têm normalmente sido escritas ou "adaptadas" para crianças. Mas assim pode ser com música, ou poesia, ou romances, ou história, ou manuais científicos. É um processo perigoso, mesmo quando é necessário. Ele é, de fato, somente salvo do desastre pelo fato de que as artes e ciências não são como um todo relegadas ao berçário; ao berçário e à sala de aula meramente são dados tais gostos e vislumbres da coisa adulta como os que parecem adequados a eles na opinião adulta (freqüentemente muito equivocada). Qualquer uma dessas coisas se tornaria, se deixada de todo no berçário, gravemente debilitada. Assim uma bela mesa, uma boa pintura, ou uma maquina útil (tal como um microscópio) seria desfigurada ou quebrada, se deixada por muito tempo desatendida numa sala de aula. Estórias de fadas banidas dessa maneira, desligadas de uma arte plena e adulta, no final seriam arruinadas; de fato, na medida em que elas foram assim banidas, elas foram arruinadas.

O valor das estórias de fadas, assim, não deve, na minha opinião, ser encontrado ao se considerar as crianças em particular. Coleções de estórias de fadas são, na verdade, por natureza porões e quartos de despejo, só por costume temporário e local quartos de brinquedo. Seus conteúdos estão desordenados, e freqüentemente amarrotados, uma maçaroca de diferentes datas, propósitos e gostos; mas entre elas pode ocasionalmente ser encontrada uma coisa de virtude permanente: uma velha obra de arte, não demasiado danificada, que só a estupidez teria deixado esquecida.

Os Fairy Books de Andrew Lang não são, talvez, quartos de despejo. Eles são mais como prateleiras num bazar. Alguém com um espanador e um bom olho para coisas que retêm algum valor circulou pelos porões e depósitos. Suas coleções são em grande parte um subproduto de seu estudo adulto de mitologia e folclore; mas elas foram transformados em, e apresentadas como, livros para crianças. ${ }^{95}$ Algumas das razões que Lang deu para isso são dignas de considerar.

\footnotetext{
${ }^{94}$ Ver Nota C no final (p. 24).

${ }^{95}$ Por Lang e seus auxiliares. Isso não é verdade quanto à maioria dos conteúdos em suas formas originais (ou nas mais antigas que sobrevivem).
} 
The introduction to the first of the series speaks of 'children to whom and for whom they are told'. 'They represent', he says, 'the young age of man true to his early loves, and have his unblunted edge of belief, a fresh appetite for marvels.' "'Is it true?"' he says, 'is the great question children ask.'

I suspect that belief and appetite for marvels are here regarded as identical or as closely related. They are radically different, though the appetite for marvels is not at once or at first differentiated by a growing human mind from its general appetite. It seems fairly clear that Lang was using belief in its ordinary sense: belief that a thing exists or can happen in the real (primary) world. If so, then I fear that Lang's words, stripped of sentiment, can only imply that the teller of marvellous tales to children, must, or may, or at any rate does trade on their credulity, on the lack of experience which makes it less easy for children to distinguish fact from fiction in particular cases, though the distinction in itself is fundamental to the sane human mind, and to fairy-stories.

Children are capable, of course, of literary belief, when the story-maker's art is good enough to produce it. That state of mind has been called 'willing suspension of disbelief'. But this does not seem to me a good description of what happens. What really happens is that the story-maker proves a successful 'sub-creator'. He makes a Secondary World which your mind can enter. Inside it, what he relates is 'true': it accords with the laws of that world. You therefore believe it, while you are, as it were, inside. The moment disbelief arises, the spell is broken; the magic, or rather art, has failed. You are then out in the Primary World again, looking at the little abortive Secondary World from outside. If you are obliged, by kindliness or circumstance, to stay, then disbelief must be suspended (or stifled), otherwise listening and looking would become intolerable. But this suspension of disbelief is a substitute for the genuine thing, a subterfuge we use when condescending to games or make-believe, or when trying (more or less willingly) to find what virtue we can in the work of an art that has for us failed. 
A introdução para o primeiro livro da série fala das "crianças a quem e para quem elas são contadas". "Elas representam", diz ele, "a era juvenil do homem leal a seus primeiros amores, e têm seu afiado gume de crença, um apetite fresco por maravilhas". “ 'É verdade?", diz ele, "é a grande pergunta que as crianças fazem”.

Suspeito que crença e apetite por maravilhas são aqui considerados idênticos ou proximamente relacionados. Eles são radicalmente diferentes, embora o apetite por maravilhas não seja de uma vez ou a princípio diferenciado por uma mente humana em crescimento de seu apetite geral. Parece razoavelmente claro que Lang está usando crença no seu sentido ordinário: crença de que uma coisa existe ou pode acontecer no mundo real (primário). Se for assim, então temo que as palavras de Lang, despidas de sentimento, só podem implicar que o contador de $\operatorname{contos}^{96}$ maravilhosos para crianças deve, ou pode, ou de qualquer modo realmente lucra com a credulidade delas, com a falta de experiência que torna menos fácil para as crianças distinguir fato de ficção em casos particulares, embora a distinção em si mesma seja fundamental para a mente humana sã, e para as estórias de fadas.

As crianças são capazes, é claro, de crença literária, quando a arte do criador de estórias é boa o suficiente para produzi-la. Esse estado da mente tem sido chamado de "suspensão voluntária da descrença". Mas isso não me parece uma boa descrição do que acontece. O que realmente acontece é que o criador de estórias prova ser um "subcriador" bem-sucedido. Ele cria um Mundo Secundário que a sua mente pode adentrar. Dentro dele, o que relata é "verdadeiro": está de acordo com as leis daquele mundo. Você, portanto, acredita, enquanto está, de certa forma, ali dentro. No momento em que a descrença surge, o feitiço se quebra; a magia, ou melhor, a arte, falhou. Você então está fora, no Mundo Primário de novo, olhando para o pequeno e abortivo Mundo Secundário de fora. Se você for obrigado, por bondade ou circunstância, a ficar, então a descrença tem de ser suspensa (ou abafada), do contrário ouvir e olhar tornar-se-iam intoleráveis. Mas essa suspensão da descrença é um substituto da coisa genuína, um subterfúgio que usamos quando condescendemos a jogos ou faz-de-conta, ou quando tentamos (mais ou menos voluntariamente) achar a virtude que pudermos numa obra de arte que para nós falhou.

\footnotetext{
${ }^{96}$ Se a repetição parece algo irritante ou idiota, é bom lembrar que o efeito de teller of tales em inglês não muito diferente, pelo menos para quem estiver com os ouvidos abertos para a conexão significantesignificado. (N. do T.)
} 
A real enthusiast for cricket is in the enchanted state: Secondary Belief. I, when I watch a match, am on the lower level. I can achieve (more or less) willing suspension of disbelief, when I am held there and supported by some other motive that will keep away boredom: for instance, a wild, heraldic, preference for dark blue rather than light. This suspension of disbelief may thus be a somewhat tired, shabby, or sentimental state of mind, and so lean to the 'adult'. I fancy it is often the state of adults in the presence of a fairy-story. They are held there and supported by sentiment (memories of childhood, or notions of what childhood ought to be like); they think they ought to like the tale. But if they really liked it, for itself, they would not have to suspend disbelief: they would believe - in this sense.

Now if Lang had meant anything like this there might have been some truth in his words. It may be argued that it is easier to work the spell with children.

Perhaps it is, though I am not sure of this. The appearance that it is so is often, I think, an adult illusion produced by children's humility, their lack of critical experience and vocabulary and their voracity (proper to their rapid growth). They like or try to like what is given to them: if they do not like it, they cannot well express their dislike or give reasons for it (and so may conceal it); and they like a great mass of different things indiscriminately, without troubling to analyse the planes of their belief. In any case I doubt if this potion - the enchantment of the effective fairy-story - is really one of the kind that becomes 'blunted' by use, less potent after repeated draughts.

"'Is it true?" is the great question children ask', Lang said. They do ask that question, I know; and it is not one to be rashly or idly answered. ${ }^{97}$ But that question is hardly evidence of 'unblunted belief', or even of the desire for it. Most often it proceeds from the child's desire to know which kind of literature he is faced with. Children's knowledge of the world is often so small that they cannot judge, off-hand and without help, between the fantastic, the strange (that is rare or remote facts), the nonsensical, and the merely 'grown-up' (that is ordinary things of their parents' world,

\footnotetext{
${ }^{97}$ Far more often they have asked me: 'Was he good? Was he wicked?' That is, they were more concerned to get the Right side and the Wrong side clear. For that is a question equally important in History and in Faerie.
} 
Um verdadeiro entusiasta do críquete está no estado encantado: Crença Secundária. Eu, quando vejo uma partida, estou no nível inferior. Consigo atingir uma suspensão (mais ou menos) voluntária da descrença, quando estou preso lá e apoiado por algum outro motivo que mantenha o tédio à distância: por exemplo, uma preferência selvagem, heráldica, por azul escuro em vez de azul claro. Essa suspensão da descrença pode, assim, ser um estado algo cansado, desmazelado ou sentimental da mente, e portanto se inclinar para o "adulto". Imagino que esse seja freqüentemente o estado dos adultos na presença de uma estória de fadas. Eles são segurados ali e apoiados por sentimento (memórias da infância, ou noções de como a infância deveria ser); acham que devem gostar da estória. Mas se realmente gostassem dela, por si mesma, não teriam de suspender a descrença: eles acreditariam - nesse sentido.

Ora, se Lang tivesse desejado dizer algo assim, poderia ter havido alguma verdade em suas palavras. Pode-se argumentar que é mais fácil operar o feitiço com crianças. Talvez seja, embora eu não esteja certo disso. A aparência de que o seja freqüentemente é, acho, uma ilusão adulta produzida pela humildade das crianças, por sua falta de experiência crítica e vocabulário, e por sua voracidade (própria do seu crescimento rápido). Elas gostam ou tentam gostar do que é dado a elas: se não gostam, não conseguem expressar bem o seu desgosto ou dar razões para ele (e então podem escondê-lo); e elas gostam de uma grande massa de coisas diferentes indiscriminadamente, sem se preocupar em analisar os planos de sua crença. Em todo caso, duvido que essa poção - o encantamento da estória de fadas eficaz - seja realmente do tipo que se torna "cego" pelo uso, menos potente depois de goles repetidos.

“ 'É verdade'? é a grande pergunta que as crianças fazem”, disse Lang. Elas realmente fazem essa pergunta, eu sei; e não é uma que deva ser apressada ou descuidadamente respondida. ${ }^{98}$ Mas essa pergunta dificilmente é evidência de "crença afiada", ou mesmo do desejo dela. Com mais freqüência, ela vem do desejo da criança de saber com que tipo de literatura está se defrontando. $\mathrm{O}$ conhecimento das crianças sobre o mundo é freqüentemente tão pequeno que elas não conseguem discriminar, de cara e sem ajuda, entre o fantástico, o estranho (isto é, fatos remotos e raros), o sem sentido e o meramente "crescido" (isto é, coisas ordinárias do mundo de seus pais,

\footnotetext{
${ }^{98}$ Muito mais freqüentemente elas me perguntaram: “Ele era bom? Ele era mau?". Isto é, elas estavam mais preocupadas em ter claro o lado Certo e o lado Errado. Pois essa é uma pergunta igualmente importante na História e em Feéria.
} 
much of which still remains unexplored). But they recognize the different classes, and may like all of them at times. Of course the borders between them are often fluctuating or confused; but that is not only true for children. We all know the differences in kind, but we are not always sure how to place anything that we hear. A child may well believe a report that there are ogres in the next county; many grown-up persons find it easy to believe of another country; and as for another planet, very few adults seem able to imagine it as peopled, if at all, by anything but monsters of iniquity.

Now I was one of the children whom Andrew Lang was addressing - I was born at about the same time as the Green Fairy Book - the children for whom he seemed to think that fairy-stories were the equivalent of the adult novel, and of whom he said: 'Their taste remains like the taste of their naked ancestors thousands of years ago; and they seem to like fairy-tales better than history, poetry, geography, or arithmetic. ${ }^{99}$ But do we really know much about these 'naked ancestors', except that they were certainly not naked? Our fairy-stories, however old certain elements in them may be, are certainly not the same as theirs. Yet if it is assumed that we have fairy-stories because they did, then probably we have history, geography, poetry, and arithmetic because they liked these things too, as far as they could get them, and in so far as they had yet separated the many branches of their general interest in everything.

And as for children of the present day, Lang's description does not fit my own memories, or my experience of children. Lang may have been mistaken about the children he knew, but if he was not, then at any rate children differ considerably, even within the narrow borders of Britain, and such generalisations which treat them as a class (disregarding their individual talents, and the influences of the countryside they live in, and their upbringing) are delusory. I had no special childish 'wish to believe'. I wanted to know. Belief depended on the way in which stories were presented to me, by older people, or by the authors, or on the inherent tone and quality of the tale. But at no time can I remember that the enjoyment of a story was dependent on belief that such things could happen, or had happened, in

\footnotetext{
${ }^{99}$ Preface to the Violet Fairy Book.
} 
muitas das quais permanecem inexploradas). Mas elas reconhecem as diferentes classes, e podem gostar de todas elas às vezes. Claro que as fronteiras entre elas são freqüentemente flutuantes ou confusas; mas isso não é verdade apenas para as crianças. Todos conhecemos as diferenças em tipo, mas não temos sempre certeza de como classificar qualquer coisa que ouvimos. Uma criança pode bem acreditar num relato de que há ogros no condado vizinho; muitas pessoas crescidas acham isso fácil de acreditar sobre um outro país; e, quanto a outro planeta, muito poucos adultos parecem capazes de imaginá-lo como habitado, se habitado, por qualquer coisa que não monstros de iniqüidade.

Ora, eu era uma das crianças a quem Andrew Lang se dirigia - eu nasci por volta da mesma época que o Green Fairy Book -, as crianças para quem ele parecia pensar que as estórias de fadas eram o equivalente do romance ${ }^{100}$ adulto, e de quem ele disse: "Seu gosto permanece como o gosto de seus ancestrais nus milhares de anos atrás; e elas parecem gostar de contos de fadas mais do que de história, poesia, geografia ou aritmética". ${ }^{101}$ Mas sabemos realmente muito sobre esses "ancestrais nus", exceto que eles certamente não estavam nus? Nossas estórias de fadas, por mais velhos que certos elementos nelas possam ser, certamente não são as mesmas que as deles. Contudo, se se assume que temos estórias de fadas porque eles tiveram, então provavelmente temos história, geografia, poesia e aritmética porque eles gostavam dessas coisas também, até onde eles podiam tê-las, e até onde eles já tinham separado os muitos ramos de seu interesse geral em tudo.

E quanto às crianças da presente época, a descrição de Lang não se encaixa nas minhas próprias memórias, ou na minha experiência com crianças. Lang pode ter se enganado sobre as crianças que conhecia, mas, se não o fez, então de qualquer modo as crianças diferem consideravelmente, mesmo dentro das fronteiras estreitas da GrãBretanha, e as generalizações que as tratam como uma classe (desconsiderando seus talentos individuais, e as influências da região onde vivem, e a sua criação) são ilusórias. Eu não tinha nenhum “desejo de acreditar” infantil especial. Eu queria saber. A crença dependia da maneira pela qual as estórias eram apresentadas a mim, por pessoas mais velhas, ou pelos autores, ou do tom e da qualidade inerentes do conto. Mas em nenhum momento consigo lembrar que a apreciação de uma estória fosse dependente da crença de que tais coisas podiam acontecer, ou tinham acontecido, na

\footnotetext{
${ }^{100}$ Neste caso, trata-se realmente de novel, e não de romance em inglês. (N. do T.)

${ }^{101}$ Prefácio do Violet Fairy Book.
} 
'real life'. Fairy-stories were plainly not primarily concerned with possibility, but with desirability. If they awakened desire, satisfying it while often whetting it unbearably, they succeeded. It is not necessary to be more explicit here, for I hope to say something later about this desire, a complex of many ingredients, some universal, some particular to modern men (including modern children), or even to certain kinds of men. I had no desire to have either dreams or adventures like Alice, and the account of them merely amused me. I had very little desire to look for buried treasure or fight pirates, and Treasure Island left me cool. Red Indians were better: there were bows and arrows (I had and have a wholly unsatisfied desire to shoot well with a bow), and strange languages, and glimpses of an archaic mode of life, and, above all, forests in such stories. But the land of Merlin and Arthur was better than these, and best of all the nameless North of Sigurd of the Völsungs, and the prince of all dragons. Such lands were pre-eminently desirable. I never imagined that the dragon was of the same order as the horse. And that was not solely because I saw horses daily, but never even the footprint of a worm. ${ }^{102}$ The dragon had the trade-mark Of Faerie written plain upon him. In whatever world he had his being it was an Other-world. Fantasy, the making or glimpsing of Other-worlds, was the heart of the desire of Faerie. I desired dragons with a profound desire. Of course, I in my timid body did not wish to have them in the neighbourhood, intruding into my relatively safe world, in which it was, for instance, possible to read stories in peace of mind, free from fear. ${ }^{103}$ But the world that contained even the imagination of Fàfnir was richer and more beautiful, at whatever cost of peril. The dweller in the quiet and fertile plains may hear of the tormented hills and the unharvested sea and long for them in his heart. For the heart is hard though the body be soft.

All the same, important as I now perceive the fairy-story element in early reading to have been, speaking for myself as a child, I can only say that a liking for fairystories was not a dominant characteristic of early taste. A real taste for them awoke after 'nursery' days, and after

\footnotetext{
${ }^{102}$ See Note D at end.

${ }^{103}$ This is, naturally, often enough what children mean when they ask:

'Is it true?' They mean: 'I like this, bur is it contemporary? Am I safe in my bed?' The answer:

'There is certainly no dragon in England today', is all that they want to hear.
} 
"vida real". As estórias de fadas claramente não se preocupavam primariamente com possibilidade, mas com desejabilidade. Se elas despertavam o desejo, satisfazendo-o enquanto freqüentemente o afiavam $^{104}$ intoleravelmente, elas tinham sucesso. Não é necessário ser mais explícito aqui, pois espero dizer algo mais tarde sobre esse desejo, um complexo de muitos ingredientes, alguns universais, outros particulares aos homens modernos (incluindo as crianças modernas), ou mesmo a certos tipos de homens. Eu não tinha desejo de ter sonhos ou aventuras como Alice, e o conjunto delas meramente me divertia. Eu tinha muito pouco desejo de procurar tesouro enterrado ou combater piratas, e $A$ Ilha do Tesouro me deixou frio. Índios eram melhores: havia arcos e flechas (eu tinha e tenho um desejo completamente insatisfeito de atirar bem com um arco), e línguas estranhas, e vislumbres de um modo arcaico de vida, e, acima de tudo, florestas em tais estórias. Mas a terra de Merlin e Arthur era melhor que essas, e o melhor de todos era o Norte sem-nome de Sigurd dos Völsungs, e do príncipe de todos os dragões. Tais terras eram preeminentemente desejáveis. Eu nunca imaginei que o dragão fosse da mesma ordem que o cavalo. E isso não era somente porque eu via cavalos diariamente, mas nunca nem a pegada de uma serpente. ${ }^{105} \mathrm{O}$ dragão tinha a marca registrada $D e$ Feéria escrita claramente sobre ele. Em qualquer mundo que ele tivesse seu ser, era um Outro Mundo. A Fantasia, o criar ou o vislumbrar de Outros Mundos, era o coração do desejo de Feéria. Eu desejava dragões com um desejo profundo. Claro, eu em meu corpo tímido não queria tê-los na vizinhança, invadindo meu mundo relativamente seguro, no qual era, por exemplo, possível ler estórias em paz de espírito, livre de medo. ${ }^{106}$ Mas o mundo que continha mesmo que a imaginação de Fáfnir ${ }^{107}$ era mais rico e mais belo, qualquer que fosse o custo em perigo. O habitante das quietas e férteis planícies pode ouvir sobre os montes atormentados e o mar não-cultivado e ansiar por eles em seu coração. Pois o coração é duro, embora o corpo seja frágil.

Mesmo assim, importante como eu percebo que foi o elemento de estória de fadas nas primeiras leituras, falando por mim mesmo enquanto criança, só posso dizer que um apreço por estórias de fadas não era uma característica dominante do gosto inicial. Um verdadeiro gosto por elas despertou depois dos dias de "berçário", e depois

\footnotetext{
${ }^{104}$ A metáfora que reaparece seguidamente nesse trecho é a de uma navalha, de uma faca cortante que representa o desejo humano. Assim, embora haja uma certa estranheza implícita, fala-se em "afiar" o desejo ou no "gume cortante" da crença. (N. do T.)

${ }^{105}$ Ver Nota D no fim (p. 26).

${ }^{106}$ Isso é, naturalmente, com bastante freqüência o que as crianças querem dizer quando perguntam: "Isso é verdade?". Elas querem dizer: "Gosto disso, mas é contemporâneo? Estou seguro na minha cama?”. A resposta: "Certamente não há nenhum dragão na Inglaterra hoje" é tudo o que elas querem ouvir.
} 
the years, few but long-seeming, between learning to read and going to school. In that (I nearly wrote 'happy' or 'golden', it was really a sad and troublous) time I liked many other things as well, or better: such as history, astronomy, botany, grammar, and etymology. I agreed with Lang's generalised 'children' not at all in principle, and only in some points by accident: I was, for instance, insensitive to poetry, and skipped it if it came in tales. Poetry I discovered much later in Latin and Greek, and especially through being made to try and translate English verse into classical verse. A real taste for fairy-stories was wakened by philology on the threshold of manhood, and quickened to full life by war.

I have said, perhaps, more than enough on this point. At least it will be plain that in my opinion fairy-stories should not be specially associated with children. They are associated with them: naturally, because children are human and fairy-stories are a natural human taste (though not necessarily a universal one); accidentally, because fairy-stories are a large part of the literary lumber that in latter-day Europe has been stuffed away in attics; unnaturally, because of erroneous sentiment about children, a sentiment that seems to increase with the decline in children.

It is true that the age of childhood-sentiment has produced some delightful books (especially charming, however, to adults) of the fairy kind or near to it; but it has also produced a dreadful undergrowth of stories written or adapted to what was or is conceived to be the measure of children's minds and needs. The old stories are mollified or bowdlerised, instead of being reserved; the imitations are often merely silly, Pigwiggenry without even the intrigue; or patronising; or (deadliest of all) covertly sniggering, with an eye on the other grown-ups present. I will not accuse Andrew Lang of sniggering, but certainly he smiled to himself, and certainly too often he had an eye on the faces of other clever people over the heads of his child-audience - to the very grave detriment of the Chronicles of Pantouflia. Dasent replied with vigour and justice to the prudish critics of his translations from Norse popular tales. Yet he committed the astonishing folly of

${ }^{107}$ É o nome do grande dragão da saga dos Völsungs. (N. do T.) 
dos anos, poucos mas longos em aparência, entre aprender a ler e ir para a escola. Nessa (eu quase escrevi "feliz" ou "dourada", na realidade foi uma triste e atribulada) época eu gostava de muitas outras coisas igualmente, ou mais ainda: tais como história, astronomia, botânica, gramática e etimologia. Eu não concordava de jeito nenhum com as "crianças" generalizadas de Lang em princípio, e só em alguns pontos por acidente: eu era, por exemplo, insensível à poesia, e a pulava se ela aparecesse em contos. A poesia eu descobri muito mais tarde no latim e no grego, e especialmente ao ser levado a tentar traduzir versos ingleses para versos clássicos. Um verdadeiro gosto por estórias de fadas foi despertado pela filologia no limiar da idade adulta, e apressado para a vida plena pela guerra.

Eu disse, talvez, mais do que o suficiente neste ponto. Pelo menos ficará claro que na minha opinião estórias de fadas não deveriam ser especialmente associadas a crianças. Elas são associadas a elas: naturalmente, porque crianças são humanas e estórias de fadas são um gosto humano natural (embora não necessariamente universal): acidentalmente, porque as estórias de fadas são uma grande parte do restolho literário que na Europa mais recente foi enfiado em porões; não-naturalmente, por causa de um sentimento errôneo em relação às crianças, um sentimento que parece crescer com o declínio no número de crianças. ${ }^{108}$

É verdade que a era do sentimento da infância produziu alguns livros deliciosos (especialmente encantadores, no entanto, para adultos) do tipo feérico ou próximo dele; mas também produziu um terrível matagal de estórias escritas ou adaptadas para o que era ou é concebido como a medida das mentes e necessidades das crianças. As velhas estórias são amolecidas ou censuradas, em vez de serem reservadas; as imitações com freqüência são meramente bobas, pigwiggenrescas sem nem mesmo a intriga; ou pseudoprotetoras; ou (as mais mortais de todas) implicitamente debochadas, com um olho nos outros adultos presentes. Não acusarei Andrew Lang de deboche, mas ele certamente sorria para si mesmo, e certamente com freqüência demasiado grande ficava de olho nos rostos de outras pessoas espertas acima das cabeças de sua audiência infantil - para o detrimento muito grave das Crônicas de Pantúflia.

Dasent respondeu com vigor e justiça aos críticos moralistas de suas traduções de contos populares nórdicos. Contudo, ele cometeu a impressionante insensatez de

\footnotetext{
${ }^{108}$ Tentei fazer da relutância em desenvolver ou explicar o original uma das marcas da presente tradução, mas essa passagem em especial pareceu exigir pelo menos certo grau disso, ou do contrário ficaria ininteligível. (N. do T.)
} 
particularly forbidding children to read the last two in his collection. That a man could study fairy-stories and not learn better than that seems almost incredible. But neither criticism, rejoinder, nor prohibition would have been necessary if children had not unnecessarily been regarded as the inevitable readers of the book. I do not deny that there is a truth in Andrew Lang's words (sentimental though they may sound): 'He who would enter into the Kingdom of Faerie should have the heart of a little child.' For that possession is necessary to all high adventure, into kingdoms both less and far greater than Faerie. But humility and innocence these things 'the heart of a child' must mean in such a context - do not necessarily imply an uncritical wonder, nor indeed an uncritical tenderness. Chesterton once remarked that the children in whose company he saw Maeterlinck's Blue Bird were dissatisfied 'because it did not end with a Day of Judgement, and it was not revealed to the hero and the heroine that the Dog had been faithful and the Cat faithless'. 'For children', he says, 'are innocent and love justice; while most of us are wicked and naturally prefer mercy.' Andrew Lang was confused on this point. He was at pains to defend the slaying of the Yellow Dwarf by Prince Ricardo in one of his own fairy-stories. 'I hate cruelty,' he said, '. . . but that was in fair fight, sword in hand, and the dwarf, peace to his ashes! died in harness.' Yet it is not clear that 'fair fight' is less cruel than 'fair judgement'; or that piercing a dwarf with a sword is more just than the execution of wicked kings and evil stepmothers which Lang abjures: he sends the criminals (as he boasts) to retirement on ample pensions. That is mercy untempered by justice. It is true that this plea was not addressed to children but to parents and guardians, to whom Lang was recommending his own Prince Prigio and Prince Ricardo as suitable for their charges. ${ }^{109}$ It is parents and guardians who have classified fairy-stories as Juvenilia. And this is a small sample of the falsification of values that results. If we use child in a good sense (it has also legitimately a bad one) we must not allow that to push us into the sentimentality of only using adult or grown-up in a bad sense (it has also legitimately a good one). The process of growing older is not necessarily allied to growing

$\overline{{ }^{109} \text { Preface to the Lilac Fairy Book. }}$ 
proibir em particular as crianças de lerem os dois últimos de sua coleção. Que um homem pudesse estudar estórias de fadas e não aprender mais que isso parece quase incrível. Mas nem crítica, advertência ou proibição teriam sido necessárias se as crianças não tivessem sido desnecessariamente consideradas as leitoras inevitáveis do livro.

Não nego que haja uma verdade nas palavras de Andrew Lang (por sentimentais que possam soar): "Aquele que quer entrar no Reino de Feéria deve ter o coração de uma criancinha". Pois essa posse é necessária para toda alta aventura, em reinos menores e muito maiores que Feéria. Mas humildade e inocência - essas coisas "o coração de uma criança" deve significar em tal contexto - não implicam necessariamente um assombro acrítico, nem, de fato, uma ternura acrítica. Chesterton certa vez afirmou que as crianças em cuja companhia ele viu O Pássaro Azul, de Maeterlinck, ficaram insatisfeitas "porque não terminava com um Dia do Juízo, e não era revelado ao herói e à heroína que o Cão tinha sido fiel e o Gato infiel". "Pois as crianças", disse ele, "são inocentes e amam a justiça; enquanto a maioria de nós é perversa e naturalmente prefere a misericórdia".

Andrew Lang ficava confuso com esse ponto. Ele teve dificuldades para defender a morte do Anão Amarelo pelo Príncipe Ricardo em uma de suas próprias estórias de fadas. "Odeio a crueldade”, disse ele, “... mas aquilo foi numa luta justa, espada na mão, e o anão, paz às suas cinzas! morreu em armas”. Contudo, não está claro que "luta justa" seja mais cruel que "julgamento justo"; ou que atravessar um anão com uma espada seja mais justo que a execução de reis perversos e madrastas malvadas que Lang abjura: ele manda seus criminosos (como se vangloria) para a aposentadoria em amplas pensões. Isso é misericórdia não temperada por justiça. É verdade que essa petição foi endereçada não às crianças, mas a pais e responsáveis, a quem Lang estava recomendando seus próprios Príncipe Prígio e Príncipe Ricardo como adequados aos seus deveres. ${ }^{110}$ Foram pais e responsáveis que classificaram as estórias de fadas como Juvenilia. E essa é uma pequena amostra da falsificação de valores que daí resulta.

Se usamos criança num bom sentido (o termo também tem legitimamente um sentido ruim), não devemos permitir que isso nos empurre ao sentimentalismo de só usar adulto ou crescido num mau sentido (o termo também tem legitimamente um bom sentido). O processo de ficar mais velho não está necessariamente ligado ao de ficar

${ }^{110}$ Prefácio do Livro Lilás das Fadas 
wickeder, though the two do often happen together. Children are meant to grow up, and not to become Peter Pans. Not to lose innocence and wonder; but to proceed on the appointed journey: that journey upon which it is certainly not better to travel hopefully than to arrive, though we must travel hopefully if we are to arrive. But it is one of the lessons of fairy-stories (if we can speak of the lessons of things that do not lecture) that on callow, lumpish, and selfish youth peril, sorrow, and the shadow of death can bestow dignity, and even sometimes wisdom. Let us not divide the human race into Eloi and Morlocks: pretty children - 'elves' as the eighteenth century often idiotically called them - with their fairytales (carefully pruned), and dark Morlocks tending their machines. If fairy-story as a kind is worth reading at all it is worthy to be written for and read by adults.

They will, of course, put more in and get more out than children can. Then, as a branch of a genuine art, children may hope to get fairy-stories fit for them to read and yet within their measure; as they may hope to get suitable introductions to poetry, history, and the sciences. Though it may be better for them to read some things, especially fairy-stories, that are beyond their measure rather than short of it. Their books like their clothes should allow for growth, and their books at any rate should encourage it.

Very well, then. If adults are to read fairy-stories as a natural branch of literature neither playing at being children, nor pretending to be choosing for children, nor being boys who would not grow up - what are the values and functions of this kind? That is, I think, the last and most important question. I have already hinted at some of my answers. First of all: if written with art, the prime value of fairystories will simply be that value which, as literature, they share with other literary forms. But fairy-stories offer also, in a peculiar degree or mode, these things: Fantasy, Recovery, Escape, Consolation, all things of which children have, as a rule, less need than older people. Most of them are nowadays very commonly considered to be bad for anybody. I will consider them briefly, and will begin with Fantasy.

FANTASY 
mais perverso, embora as duas coisas freqüentemente aconteçam juntas. As crianças têm de crescer, e não se tornar Peter Pans. Não perder a inocência e o assombro, mas proceder na jornada designada: aquela jornada na qual certamente não é melhor viajar com esperança do que chegar, embora devamos viajar com esperança se quisermos chegar. Mas é uma das lições das estórias de fadas (se podemos falar das lições de coisas que não lecionam) que sobre a juventude insensível, preguiçosa e egoísta o perigo, a tristeza e a sombra da morte podem derramar dignidade, e às vezes até sabedoria.

Não dividamos a raça humana em Eloi e Morlocks: crianças bonitas - "elfos", como o século XVIII as chamava freqüentemente de maneira idiota - com seus contos de fadas (cuidadosamente podados), e sombrios Morlocks cuidando de suas máquinas. Se a estória de fadas como um gênero é digna de ser lida de alguma forma, ela é digna de ser escrita para e lida por adultos. Eles vão, é claro, colocar e tirar mais do que crianças conseguem. Então, como um ramo de uma arte genuína, as crianças podem esperar obter estórias de fadas adequadas para lerem, e contudo dentro de sua medida; como podem esperar obter introduções acertadas de poesia, história e ciências. Embora possa ser melhor para elas ler algumas coisas, especialmente estórias de fadas, que estejam além de sua medida em vez de aquém dela. Seus livros, assim como suas roupas, deveriam permitir o crescimento, e seus livros, de qualquer modo, deveriam encorajá-lo.

Pois muito bem. Se os adultos devem ler estórias de fadas como um ramo natural da literatura - nem brincando de serem crianças, nem fingindo estar escolhendo para crianças, nem sendo garotos que não querem crescer - quais são os valores e funções desse gênero? Essa é, acho eu, a última e mais importante questão. Já dei pistas de algumas de minhas respostas. Em primeiro lugar, se escritas com arte, o valor primário das estórias de fadas será aquele valor que, como literatura, elas partilham com outras formas literárias. Mas as estórias de fadas também oferecem, num grau ou modo peculiar, estas coisas: Fantasia, Recuperação, Escape, Consolação, todas coisas das quais as crianças têm, via de regra, menos necessidade do que as pessoas mais velhas. A maioria delas é, hoje em dia, muito comumente considerada ruim para qualquer um. Considerá-las-ei brevemente, e começarei com a Fantasia. 
The human mind is capable of forming mental images of things not actually present. The faculty of conceiving the images is (or was) naturally called Imagination. But in recent times, in technical not normal language, Imagination has often been held to be something higher than the mere image-making, ascribed to the operations of Fancy (a reduced and depreciatory form of the older word Fantasy); an attempt is thus made to restrict, I should say misapply, Imagination to 'the power of giving to ideal creations the inner consistency of reality'.

Ridiculous though it may be for one so ill-instructed to have an opinion in this critical matter, I venture to think the verbal distinction philologically inappropriate, and the analysis inaccurate. The mental power of image-making is one thing, or aspect; and it should appropriately be called Imagination. The perception of the image, the grasp of its implications, and the control, which are necessary to a successful expression, may vary in vividness and strength: but this is a difference of degree in Imagination, not a difference in kind. The achievement of the expression, which gives (or seems to give) 'the inner consistency of reality', ${ }^{111}$ is indeed another thing, or aspect, needing another name: Art, the operative link between Imagination and the final result, Sub-creation. For my present purpose I require a word which shall embrace both the Sub-creative Art in itself and a quality of strangeness and wonder in the Expression, derived from the Image: a quality essential to fairy-story. I propose, therefore, to arrogate to myself the powers of Humpty-Dumpty, and to use Fantasy for this purpose: in a sense, that is, which combines with its older and higher use as an equivalent of Imagination the derived notions of 'unreality' (that is, of unlikeness to the Primary World), of freedom from the domination of observed 'fact', in short of the fantastic. I am thus not only aware but glad of the etymological and semantic connections of fantasy with fantastic: with images of things that are not only 'not actually present', but which are indeed not to be found in our primary world at all, or are generally believed not to be found there. But while admitting that, I do not assent to the depreciative tone. That the images are of things not

\footnotetext{
${ }^{111}$ That is: which commands or induces Secondary Belief.
} 
A mente humana é capaz de formar imagens mentais de coisas que não estão realmente presentes. A faculdade de conceber as imagens é (ou era) naturalmente chamada de Imaginação. Mas em épocas recentes, na linguagem técnica e não normal, a Imaginação freqüentemente tem sido considerada algo mais elevado que a mera criação de imagens, atribuída às operações de Fancy, "devaneio" (uma forma reduzida e depreciativa da palavra mais antiga Fantasy, Fantasia); ${ }^{112}$ faz-se, assim, uma tentativa de restringir, eu deveria dizer aplicar erradamente, Imaginação ao "poder de dar a criações ideais a consistência interna da realidade".

Embora seja ridículo para alguém tão mal-instruído ter uma opinião sobre essa matéria crítica, eu arrisco achar a distinção verbal filologicamente inapropriada, e a análise não-acurada. O poder mental da criação de imagens é uma coisa, ou aspecto; e deveria apropriadamente ser chamado de Imaginação. A percepção da imagem, a compreensão de suas implicações e o controle, que são necessários para uma expressão bem-sucedida, podem variar em vivacidade e força: mas isso é uma diferença de grau na Imaginação, não uma diferença de tipo. A realização da expressão, que confere (ou parece conferir) "a consistência interna da realidade", ${ }^{113}$ é de fato outra coisa, ou aspecto, que precisa de outro nome: Arte, o liame operativo entre a Imaginação e o resultado final, a Sub-criação. Para o meu propósito presente, eu preciso de uma palavra que abrace tanto a Arte Sub-criativa em si mesma quanto uma qualidade de estranheza e assombro na Expressão, derivada da Imagem: uma qualidade essencial à estória de fadas. Proponho, portanto, me arrogar os poderes de Humpty-Dumpty, e usar Fantasia $^{114}$ para esse propósito; num sentido, isto é, que combina com seu uso mais antigo e elevado como um equivalente de Imaginação as noções derivadas de "irrealidade" (isto é, de dessemelhança com o Mundo Primário), de liberdade da dominação do "fato" observado, em resumo, do fantástico. Assim, não estou apenas ciente delas, mas contente com as conexões etimológicas e semânticas de fantasia com fantástico: com imagens de coisas que não apenas não estão "realmente presentes", mas que de fato não podem ser encontradas no nosso mundo primário de forma alguma, ou que geralmente se acredita não serem encontradas ali. Mas, embora admita isso, eu não concordo com o tom depreciativo. Que as imagens sejam de coisas que não estão no

\footnotetext{
${ }^{112}$ Conforme referido na discussão teórica acima, uma relação do tipo da que existe entre fancy e fantasy é inescapavelmente dependente da história particular de cada idioma, e as chances de que se repita em mais de uma língua são praticamente nulas. Daí a necessidade de utilizar as palavras no original.

${ }^{113}$ Isto é: que ordena ou induz a Crença Secundária.
} 
in the primary world (if that indeed is possible) is a virtue not a vice. Fantasy (in this sense) is, I think, not a lower but a higher form of Art, indeed the most nearly pure form, and so (when achieved) the most potent.

Fantasy, of course, starts out with an advantage: arresting strangeness. But that advantage has been turned against it, and has contributed to its disrepute. Many people dislike being 'arrested'. They dislike any meddling with the Primary World, or such small glimpses of it as are familiar to them. They, therefore, stupidly and even maliciously confound Fantasy with Dreaming, in which there is no Art; ${ }^{15}$ and with mental disorders, in which there is not even control: with delusion and hallucination.

But the error or malice, engendered by disquiet and consequent dislike, is not the only cause of this confusion. Fantasy has also an essential drawback: it is difficult to achieve. Fantasy may be, as I think, not less but more sub-creative; but at any rate it is found in practice that 'the inner consistency of reality' is more difficult to produce, the more unlike are. the images and the rearrangements of primary material to the actual arrangements of the Primary World. It is easier to produce this kind of 'reality' with more 'sober' material. Fantasy thus, too often, remains undeveloped; it is and has been used frivolously, or only half-seriously, or merely for decoration: it remains merely 'fanciful'. Anyone inheriting the fantastic device of human language can say the green sun. Many can then imagine or picture it. But that is not enough - though it may already be a more potent thing than many a 'thumbnail sketch' or 'transcript of life' that receives literary praise.

To make a Secondary World inside which the green sun will be credible, commanding Secondary Belief, will probably require labour and thought, and will certainly demand a special skill, a kind of elvish craft. Few attempt such difficult tasks. But when they are attempted and in any degree accomplished then we have a rare achievement of Art: indeed narrative art, story-making in its primary and most potent mode.

In human art Fantasy is a thing best left to words, to true literature. In painting, for instance, the visible presentation of the fantastic image is

\footnotetext{
${ }^{114}$ Outra vez Tolkien brinca com a etimologia (nesse caso, grega): fantasy, nesse caso, pode ser considerado o equivalente de imagination no sentido "aquilo que aparece como imagem".

${ }^{115}$ This is not true of all dreams. In some Fantasy seems to take a part.

But this is exceptional. Fantasy is a rational not an irrational activity.
} 
mundo primário (se isso de fato é possível) é uma virtude, não um vício. A Fantasia (nesse sentido) é, acho, não uma forma inferior mas superior de Arte, de fato a forma mais proximamente pura, e portanto (quando realizada) a mais potente.

A Fantasia, é claro, começa com uma vantagem: estranheza arrebatadora. Mas essa vantagem foi voltada contra ela, e contribuiu para sua difamação. Muitas pessoas não gostam de ser arrebatadas. Não gostam de qualquer interferência no Mundo Primário, ou naqueles pequenos vislumbres dele que são familiares a elas. Portanto, estúpida e mesmo maliciosamente, confundem Fantasia com Sonho, no qual não há Arte; ${ }^{116}$ e com distúrbios mentais, nos quais não há nem mesmo controle: com a ilusão e a alucinação.

Mas o erro ou malícia, engendrada pela inquietação e pelo conseqüente desgosto, não é a única causa dessa confusão. A Fantasia tem também uma desvantagem essencial: é difícil de realizar. A Fantasia pode ser, como eu acho, não menos mas mais sub-criativa; mas de qualquer modo descobre-se na prática que a "consistência interna da realidade" é tão mais difícil de produzir quanto mais diferentes forem as imagens e os rearranjos de material primário dos arranjos reais do Mundo Primário. É mais fácil produzir esse tipo de "realidade" com material mais "sóbrio". A Fantasia, assim, com demasiada freqüência, permanece não-desenvolvida; é e foi usada de forma frívola, ou apenas de forma meio séria, ou meramente para decoração: permanece meramente "fantasiosa". Qualquer um que tenha herdado o aparato fantástico da linguagem humana pode dizer o sol verde. Muitos podem então imaginá-lo ou pintá-lo. Mas isso não é suficiente - embora já possa ser uma coisa mais potente do que muito "rascunho em miniatura" ou "transcrição da vida" que recebe elogio literário.

Criar um Mundo Secundário dentro do qual o sol verde seja crível, ordenando a Crença Secundária, provavelmente vai requerer labuta e pensamento, e certamente vai exigir uma perícia especial, um tipo de destreza élfica. Poucos tentam tais difíceis tarefas. Mas quando elas são tentadas e em qualquer grau completadas, então temos uma rara realização de Arte: de fato arte narrativa, criação de estórias em seu modo primário e mais potente.

$\mathrm{Na}$ arte humana a Fantasia é algo que é melhor deixar às palavras, à verdadeira literatura. Na pintura, por exemplo, a apresentação visível da imagem fantástica é

\footnotetext{
${ }^{116}$ Isso não é verdade de todos os sonhos. Em alguns a Fantasia parece desempenhar um papel. Mas isso é excepcional. A Fantasia é uma atividade racional, não irracional.
} 
technically too easy; the hand tends to outrun the mind, even to overthrow it. ${ }^{117}$ Silliness or morbidity are frequent results. It is a misfortune that Drama, an art fundamentally distinct from Literature, should so commonly be considered together with it, or as a branch of it. Among these misfortunes we may reckon the depreciation of Fantasy. For in part at least this depreciation is due to the natural desire of critics to cry up the forms of literature or 'imagination' that they themselves, innately or by training, prefer. And criticism in a country that has produced so great a Drama, and possesses the works of William Shakespeare, tends to be far too dramatic. But Drama is naturally hostile to Fantasy. Fantasy, even of the simplest kind, hardly ever succeeds in Drama, when that is presented as it should be, visibly and audibly acted. Fantastic forms are not to be counterfeited. Men dressed up as talking animals may achieve buffoonery or mimicry, but they do not achieve Fantasy. This is, I think, well illustrated by the failure of the bastard form, pantomime. The nearer it is to 'dramatised fairy-story' the worse it is. It is only tolerable when the plot and its fantasy are reduced to a mere vestigiary framework for farce, and no 'belief' of any kind in any part of the performance is required or expected of anybody. This is, of course, partly due to the fact that the producers of drama have to, or try to, work with mechanism to represent either Fantasy or Magic. I once saw a so-called 'children' s pantomime', the straight story of Puss-in-Boots, with even the metamorphosis of the ogre into a mouse. Had this been mechanically successful it would either have terrified the spectators or else have been just a turn of high-class conjuring. As it was, though done with some ingenuity of lighting, disbelief had not so much to be suspended as hung, drawn, and quartered.

In Macbeth, when it is read, I find the witches tolerable: they have a narrative function and some hint of dark significance; though they are vulgarised, poor things of their kind. They are almost intolerable in the play. They would be quite intolerable, if I were not fortified by some memory of them as they are in the story as read. I am told that I should feel differently if I had the mind of the period, with its witch-hunts and witch-trials. But that is to say: if I regarded the witches as possible, indeed likely, in the Primary World; in other words, if they ceased to be 'Fantasy'. That argument concedes the point. To be dissolved, or to be

${ }^{117}$ See Note E at end. 
tecnicamente fácil demais; a mão tende a ser mais rápida que a mente, e mesmo a derrotá-la. ${ }^{118}$ Tolice ou morbidez são resultados freqüentes. É um infortúnio que o Drama, uma arte fundamentalmente distinta da Literatura, seja tão comumente considerado com ela, ou como um ramo dela. Entre esses infortúnios podemos contar a depreciação da Fantasia. Pois em parte, pelo menos, essa depreciação se deve ao desejo natural dos críticos de promover as formas de literatura ou imaginação que eles próprios, de forma inata ou por treinamento, preferem. E a crítica, num país que produziu tão grande Drama, e possui as obras de William Shakespeare, tende a ser dramática demais. Mas o Drama é naturalmente hostil à Fantasia. A Fantasia, mesmo a do tipo mais simples, dificilmente chega a ter sucesso no Drama, quando é apresentada como deveria ser, visível e audivelmente representada. As formas fantásticas não se prestam a ser imitadas. Homens vestidos como animais falantes podem conseguir bufoneria ou arremedo, mas não conseguem Fantasia. Isso é, acho, bem ilustrado pela falha da forma bastarda, a pantomima. Quanto mais próxima está de "estória de fadas dramatizada", pior é. Só é tolerável quando a trama e sua fantasia são reduzidas a uma mera moldura vestigial para a farsa, e nenhuma "crença" de tipo algum é pedida ou esperada de ninguém. Isso, é claro, se deve em parte ao fato de que os produtores de drama têm de trabalhar, ou tentam trabalhar, com mecanismos para representar a Fantasia ou a Magia. Certa vez vi uma chamada "pantomima infantil", a estória simples de Gato-de-botas, que tinha até a metamorfose do ogro num camundongo. Tivesse isso sido mecanicamente bem-sucedido, teria ou aterrorizado os espectadores, ou então teria sido apenas um truque de prestidigitação de alto nível. Da maneira como foi, embora realizada com alguma engenhosidade de iluminação, a descrença não teve só de ser suspensa, mas enforcada, arrastada e esquartejada.

Em Macbeth, quando lido, acho as bruxas toleráveis: elas têm uma função narrativa e alguma sugestão de significância sombria; embora sejam vulgarizadas, pobres coisas de sua raça. Elas são quase intoleráveis na peça. Elas seriam bastante intoleráveis, se eu não fosse fortificado por alguma lembrança delas como são na peça quando lida. Dizem que eu sentir-me-ia diferente se tivesse a cabeça da época, com sua caça às bruxas e julgamentos de bruxas. Mas isso equivale a dizer: se eu considerasse as bruxas possíveis, de fato prováveis, no Mundo Primário; em outras palavras, se elas cessassem de ser "Fantasia". Esse argumento só comprova a idéia. Ser dissolvida, ou ser

${ }^{118}$ Ver Nota E no fim (p. 26). 
degraded, is the likely fate of Fantasy when a dramatist tries to use it, even such a dramatist as Shakespeare. Macbeth is indeed a work by a playwright who ought, at least on this occasion, to have written a story, if he had the skill or patience for that art.

A reason, more important, I think, than the inadequacy of stage-effects, is this: Drama has, of its very nature, already attempted a kind of bogus, or shall I say at least substitute, magic: the visible and audible presentation of imaginary men in a story. That is in itself an attempt to counterfeit the magician's wand. To introduce, even with mechanical success, into this quasi-magical secondary world a further fantasy or magic is to demand, as it were, an inner or tertiary world. It is a world too much. To make such a thing may not be impossible. I have never seen it done with success. But at least it cannot be claimed as the proper mode of drama, in which walking and talking people have been found to be the natural instruments of Art and illusion. ${ }^{119}$

For this precise reason - that the characters, and even the scenes, are in Drama not imagined but actually beheld - Drama is, even though it uses a similar material (words, verse, plot), an art fundamentally different from narrative art. Thus, if you prefer Drama to Literature (as many literary critics plainly do), or form your critical theories primarily from dramatic critics, or even from Drama, you are apt to misunderstand pure story-making, and to constrain it to the limitations of stageplays. You are, for instance, likely to prefer characters, even the basest and dullest, to things. Very little about trees as trees can be got into a play.

Now 'Faerian Drama' - those plays which according to abundant records the elves have often presented to men - can produce Fantasy with a realism and immediacy beyond the compass of any human mechanism. As a result their usual effect (upon a man) is to go beyond Secondary Belief. If you are present at a Faerian drama you yourself are, or think that you are, bodily inside its Secondary World. The experience may be very similar to Dreaming and has (it would seem) sometimes (by men) been confounded with it. But in Faerian drama you are in a dream that some other mind is weaving, and the knowledge of that alarming fact may slip from your grasp. To experience

\footnotetext{
${ }^{119}$ See Note F at end.
} 
degradada, é o fado provável da Fantasia quando um dramaturgo tenta usá-la, mesmo um dramaturgo tal como Shakespeare. Macbeth é, de fato, a obra de um escritor de peças que deveria, ao menos nessa ocasião, ter escrito uma estória, se tivesse tido a perícia ou a paciência para essa arte.

Uma razão mais importante, acho eu, do que a inadequação dos efeitos de palco, é esta: o Drama já tentou, por sua própria natureza, um tipo de magia falsa, ou eu diria pelo menos substituta: a apresentação visível e audivel de homens imaginários numa estória. Isso é em si mesmo uma tentativa de reproduzir a varinha do mágico. Introduzir, mesmo que com sucesso mecânico, nesse quase-mágico mundo secundário, mais uma fantasia ou mágica é exigir como que um mundo interno ou terciário. É um mundo de mais. Fazer tal coisa pode não ser impossível. Eu nunca a vi ser feita com sucesso. Mas no mínimo ela não pode ser considerada o modo apropriado do Drama, no qual pessoas ambulantes e falantes têm demonstrado ser os instrumentos naturais da Arte e da ilusão. ${ }^{120}$

Por essa razão precisa - a de que os personagens, e mesmos as cenas, são no Drama não imaginados, mas realmente contemplados - o Drama é, embora use um material similar (palavras, verso, trama), uma arte fundamentalmente diferente da arte narrativa. Assim, se você preferir Drama a Literatura (como muitos críticos literários claramente o fazem), ou formar suas teorias críticas primariamente a partir de crítica dramática, ou mesmo de Drama, está inclinado a desentender a pura criação de estórias, e a restringi-la às limitações das peças de teatro. Você, por exemplo, provavelmente vai preferir personagens, mesmo os mais baixos e estúpidos, a coisas. Muito pouco das árvores enquanto árvores pode entrar numa peça.

Ora, o "Drama Feérico" - aquelas peças que, de acordo com registros abundantes, os elfos freqüentemente apresentaram aos homens - pode produzir Fantasia com um realismo e uma imediatez além do alcance de qualquer mecanismo humano. Como resultado, o seu efeito usual (sobre um homem) é ir além da Crença Secundária. Se você está presente a um drama feérico você mesmo está, ou acha que está, corporalmente dentro de seu Mundo Secundário. A experiência pode ser muito similar ao Sonho e tem sido (ao que parece) às vezes (por homens) confundida com ele. Mas no drama feérico você está num sonho que alguma outra mente está tecendo, e o conhecimento desse fato alarmante pode escapar das suas mãos. Experimentar

${ }^{120}$ Ver Nota F no fim (p. 26) 
directly a Secondary World: the potion is too strong, and you give to it Primary Belief, however marvellous the events. You are deluded - whether that is the intention of the elves (always or at any time) is another question. They at any rate are not themselves deluded. This is for them a form of Art, and distinct from Wizardry or Magic, properly so called. They do not live in it, though they can, perhaps, afford to spend more time at it than human artists can. The Primary World, Reality, of elves and men is the same, if differently valued and perceived.

We need a word for this elvish craft, but all the words that have been applied to it have been blurred and confused with other things. Magic is ready to hand, and I have used it above, but I should not have done so: Magic should be reserved for the operations of the Magician. Art is the human process that produces by the way (it is not its only or ultimate object) Secondary Belief. Art of the same sort, if more skilled and effortless, the elves can also use, or so the reports seem to show; but the more potent and specially elvish craft I will, for lack of a less debatable word, call Enchantment. Enchantment produces a Secondary World into which both designer and spectator can enter, to the satisfaction of their senses while they are inside; but in its purity it is artistic in desire and purpose. Magic produces, or pretends to produce, an alteration in the Primary World. It does not matter by whom it is said to be practised, fay or mortal, it remains distinct from the other two; it is not an art but a technique; its desire is power in this world, domination of things and wills.

To the elvish craft, Enchantment, Fantasy aspires, and when it is successful of all forms of human art most nearly approaches. At the heart of many manmade stories of the elves lies, open or concealed, pure or alloyed, the desire for a living, realised sub-creative art, which (however much it may outwardly resemble it) is inwardly wholly different from the greed for self-centred power which is the mark of the mere Magician. Of this desire the elves, in their better (but still perilous) part, are largely made; and it is from them that we may learn what is the central desire and aspiration of human Fantasy - even if the elves are, all the more in so far as they are, only a product of Fantasy itself. That creative desire is only cheated by counterfeits, whether the innocent but clumsy devices of the human dramatist, or the malevolent frauds of the magicians. In this world it is for 
diretamente um Mundo Secundário: a poção é forte demais, e você dá a ela Crença Primária, por maravilhosos que sejam os eventos. Você é iludido - se essa é a intenção dos elfos (sempre ou em qualquer momento) é outra questão. Eles, de qualquer maneira, não são eles próprios iludidos. Essa é para eles uma forma de Arte, e distinta da Feitiçaria ou Magia, propriamente assim chamadas. Eles não vivem nela, embora possam, talvez, se dar ao luxo de gastar mais tempo nela do que artistas humanos conseguem. O Mundo Primário, a Realidade, de elfos e homens é o mesmo, ainda que diferentemente valorizado e percebido.

Precisamos de uma palavra para esse ofício élfico, mas todas as palavras que foram aplicadas a ele foram borradas e confundidas com outras coisas. Magia está pronta à mão, e eu a usei acima, mas não deveria tê-lo feito: Magia deveria ser reservada para as operações do Mágico. Arte é o processo humano que produz no caminho (não é o seu único ou último objetivo) Crença Secundária. Arte da mesma sorte, ainda que mais habilidosa e sem esforço, os elfos podem também usar, ou assim os relatos parecem mostrar; mas o ofício mais potente e especialmente élfico vou, por falta de uma palavra menos contestável, chamar de Encantamento. O Encantamento produz um Mundo Secundário no qual tanto planejador quanto espectador podem entrar, para a satisfação de seus sentidos enquanto eles estão ali dentro; mas em sua pureza ele é artístico em desejo e propósito. A Magia produz, ou finge produzir, uma alteração no Mundo Primário. Não importa por quem seja praticada, fada ou mortal, ela permanece distinta dos outros dois; não é uma arte, mas uma técnica; seu desejo é poder neste mundo, dominação de coisas e vontades.

Ao ofício élfico, Encantamento, a Fantasia aspira, e quando é bem-sucedida de todas as formas de arte humana é a que mais se aproxima. No coração de muitas estórias dos elfos feitas pelo homem jaz, aberto ou oculto, puro ou amalgamado, o desejo de uma arte sub-criativa viva, concretizada, a qual (embora muito possa se parecer exteriormente com ela) é interiormente de todo diferente da ganância de poder autocentrado que é a marca do mero Mágico. Desse desejo os elfos, em sua melhor (mas ainda perigosa) parte são em grande parte feitos; e é deles que podemos aprender qual é o desejo e a aspiração central da Fantasia humana - mesmo se os elfos forem, ainda mais até onde eles são, apenas um produto da própria Fantasia. Esse desejo criativo é apenas enganado por contrafações, sejam as inocentes mas desajeitadas táticas do dramaturgo humano, sejam as fraudes malevolentes do mágico. Neste mundo ele é, para 
men unsatisfiable, and so imperishable. Uncorrupted it does not seek delusion, nor bewitchment and domination; it seeks shared enrichment, partners in making and delight, not slaves.

To many, Fantasy, this sub-creative art which plays strange tricks with the world and all that is in it, combining nouns and redistributing adjectives, has seemed suspect, if not illegitimate. To some it has seemed at least a childish folly, a thing only for peoples or for persons in their youth. As for its legitimacy I will say no more than to quote a brief passage from a letter I once wrote to a man who described myth and fairy-story as 'lies'; though to do him justice he was kind enough and confused enough to call fairy-story making 'Breathing a lie through Silver'.

'Dear Sir,' I said - 'Although now long estranged, Man is not wholly lost nor wholly changed.

Dis-graced he may be, yet is not de-throned, and keep the rags of lordship once he owned: Man, Sub-creator, the refracted Light through whom is splintered from a single White to many hues, and endlessly combined in living shapes that move from mind to mind. Though all the crannies of the world we filled with Elves and Goblins, though we dared to build Gods and their houses out of dark and light, and sowed the seed of dragons - 'twas our right (used or misused). That right has not decayed: we make still by the law in which we're made.' 
os homens, insatisfazível, ${ }^{121}$ e assim imperecível. Não-corrompido, ele não busca ilusão ou feitiço e dominação; busca enriquecimento partilhado, parceiros na criação e no deleite, não escravos.

Para muitos, a Fantasia, essa arte sub-criativa que faz truques estranhos com o mundo e com tudo o que está nele, combinando nomes e redistribuindo adjetivos, parece suspeita, se não ilegítima. Para alguns ela parece no mínimo uma insensatez infantil, uma coisa só para povos ou para pessoas em sua juventude. Quanto à sua legitimidade, não direi mais do que citar uma passagem breve de uma carta que escrevi certa vez a um homem que descreveu o mito e as estórias de fadas como "mentiras"; embora, para fazer justiça a ele, tenha sido bondoso o suficiente e estivesse confuso o suficiente para chamar a criação de estórias de fadas de "bafejar uma mentira através da Prata". ${ }^{122}$

"Caro Senhor," disse eu - "Inda que alienado,

algo no Homem não se perdeu nem foi mudado.

Des-graçado está, mas não destronado,

trapos da nobreza em que foi trajado,

domínio do mundo por criação:

O deus Artefato não é seu quinhão,

homem, sub-criador, luz refratada

em quem a cor branca é despedaçada

para muitos tons, e recombinada,

forma viva mente a mente passada.

Se todas as cavas do mundo enchemos

com elfos e duendes, se fizemos

deuses com casas de treva e de luz,

se plantamos dragões, a nós conduz

um direito. E não foi revogado.

Criamos tal como fomos criados."

\footnotetext{
${ }^{121}$ Poder-se-ia argumentar que a palavra "insaciável" deveria ser usada no lugar desse neologismo um tanto canhestro, mas não custa lembrar que insatiable estava à mão em inglês, mas Tolkien preferiu não utilizar a palavra. É a mesma escolha adotada aqui. (N. do T.)

${ }^{122}$ Aqui começa a citação quase literal de uma das estrofes de Mythopoeia, referida na introdução deste texto.
} 
Fantasy is a natural human activity. It certainly does not destroy or even insult Reason; and it does not either blunt the appetite for, nor obscure the perception of, scientific verity. On the contrary. The keener and the clearer is the reason, the better fantasy will it make. If men were ever in a state in which they did not want to know or could not perceive truth (facts or evidence), then Fantasy would languish until they were cured. If they ever get into that state (it would not seem at all impossible), Fantasy will perish, and become Morbid Delusion.

For creative Fantasy is founded upon the hard recognition that things are so in the world as it appears under the sun; on a recognition of fact, but not a slavery to it. So upon logic was founded the nonsense that displays itself in the tales and rhymes of Lewis Carroll. If men really could not distinguish between frogs and men, fairy-stories about frog-kings would not have arisen.

Fantasy can, of course, be carried to excess. It can be ill done. It can be put to evil uses. It may even delude the minds out of which it came. But of what human thing in this fallen world is that not true? Men have conceived not only of elves, but they have imagined gods, and worshipped them, even worshipped those most deformed by their authors' own evil. But they have made false gods out of other materials: their nations, their banners, their monies; even their sciences and their social and economic theories have demanded human sacrifice. Abusus non tollit usum. Fantasy remains a human right: we make in our measure and in our derivative mode, because we are made: and not only made, bur made in the image and likeness of a Maker.

\section{RECOVERY, ESCAPE, CONSOLATION}

As for old age, whether personal or belonging to the times in which we live, it may be true, as is often supposed, that this imposes disabilities. But it is in the main an idea produced by the mere study of fairy-stories. The analytic study of fairy-stories is as bad a preparation for the enjoying or the writing of them as would be the historical study of the drama of all 
A Fantasia é uma atividade natural humana. Certamente não destrói ou mesmo insulta a Razão; e não cega o apetite pela verdade científica, nem obscurece a percepção dela. Ao contrário. Quanto mais aguçada e clara a razão, melhor fantasia fará. Se os homens estivessem sempre num estado em que não quisessem conhecer ou não pudessem perceber a verdade (fatos ou evidências), então a Fantasia minguaria até que eles ficassem curados. Se alguma vez entrarem nesse estado (não pareceria de forma alguma impossível), a Fantasia perecerá, e tornar-se-á Ilusão Mórbida.

Pois a Fantasia criativa está fundada sobre o reconhecimento duro de que as coisas são assim no mundo como ele aparece sob o sol; num reconhecimento do fato, mas não numa escravidão a ele. Assim sobre a lógica foi fundado o disparate que se mostra nos contos e versos de Lewis Carroll. Se os homens realmente não pudessem distinguir entre sapos e homens, estórias de fadas sobre sapos-reis não teriam surgido.

A Fantasia pode, é claro, ser levada ao excesso. Pode ser malfeita. Pode ser posta a serviço de fins maus. Pode mesmo iludir as mentes das quais veio. Mas de que coisa humana neste mundo caído isso não é verdade? Os homens conceberam não apenas elfos, mas imaginaram deuses, e os adoraram, adoraram mesmo aqueles mais deformados pelo próprio mal de seus autores. Mas eles fizeram falsos deuses com outros materiais: suas idéias, suas bandeiras, seus dinheiros; ${ }^{123}$ até suas ciências e suas teorias sociais e econômicas exigiram sacrifício humano. Abusus non tollit usum. ${ }^{124} \mathrm{~A}$ Fantasia permanece um direito humano; criamos na nossa medida e ao nosso modo derivativo, porque fomos criados: e não apenas criados, mas criados à imagem e semelhança de um Criador.

\section{RECUPERAÇÃO, ESCAPE, ${ }^{125}$ CONSOLAÇÃO}

Quanto à idade madura, seja pessoal ou pertencente aos tempos nos quais vivemos, pode ser verdade, como se supõe freqüentemente, que ela imponha incapacidades. Mas essa é principalmente uma idéia produzida pelo mero estudo de estórias de fadas. O estudo analítico de estórias de fadas é uma preparação tão ruim para a apreciação ou a escrita delas quanto seria o estudo histórico do drama de todas as

\footnotetext{
${ }^{123}$ Em português, parece-me que a expressão "trinta dinheiros" me permite a utilização desse plural para reproduzir o efeito de monies sem grandes traumas. (N. do T.)

124 "O abuso não impede o uso". (N. do T.)

125 "Fuga" talvez soasse mais natural, mas ficaria rompida a equivalência entre "escape" e "escapismo", muito presente nesta seção do texto.
} 
lands and times for the enjoyment or writing of stage-plays. The study may indeed become depressing. It is easy for the student to feel that with all his labour he is collecting only a few leaves, many of them now torn or decayed, from the countless foliage of the Tree of Tales, with which the Forest of Days is carpeted. It seems vain to add to the litter. Who can design a new leaf? The patterns from bud to unfolding, and the colours from spring to autumn were all discovered by men long ago. Bur that is not true. The seed of the tree can be replanted in almost any soil, even in one so smoke-ridden (as Lang said) as that of England. Spring is, of course, not really less beautiful because we have seen or heard of other like events: like events, never from world's beginning to world's end the same event. Each leaf, of oak and ash and thorn, is a unique embodiment of the pattern, and for some eye this very year may be the embodiment, the first ever seen and recognized, though oaks have put forth leaves for countless generations of men.

We do not, or need not, despair of drawing because all lines must be either curved or straight, nor of painting because there are only three 'primary' colours. We may indeed be older now, in so far as we are heirs in enjoyment or in practice of many generations of ancestors in the arts. In this inheritance of wealth there may be a danger of boredom or of anxiety to be original, and that may lead to a distaste for fine drawing, delicate pattern, and 'pretty' colours, or else to mere manipulation and over-elaboration of old material, clever and heartless. But the true road of escape from such weariness is not to be found in the wilfully awkward, clumsy, or misshapen, not in making all things dark or unremittingly violent; nor in the mixing of colours on through subtlety to drabness, and the fantastical complication of shapes to the point of silliness and on towards delirium. Before we reach such states we need recovery. We should look at green again, and be startled anew (but not blinded) by blue and yellow and red. We should meet the centaur and the dragon, and then perhaps suddenly behold, like the ancient shepherds, sheep, and dogs, and horses - and wolves. This recovery fairy-stories help us to make. In that sense only a taste for them may make us, or keep us, childish. 
terras e tempos para a apreciação ou escrita de peças para o palco. O estudo pode, de fato, tornar-se deprimente. É fácil para o estudante sentir que com toda a sua labuta ele está recolhendo só algumas folhas, muitas delas rasgadas e apodrecidas, da incontável folhagem da Árvore das Estórias, com as quais a Floresta dos Dias é atapetada. Parece vão aumentar o monte. Quem pode projetar uma nova folha? Os padrões, do botão ao desabrochar, e as cores, da primavera ao outono, foram todos descobertos pelos homens há muito tempo. Mas isso não é verdade. A semente da árvore pode ser replantada em quase qualquer solo, mesmo em um tão varrido de fumaça (como dizia Lang) quanto o da Inglaterra. A primavera, é claro, não é realmente menos bela porque vimos ou ouvimos falar de outros eventos parecidos: eventos parecidos, nunca do começo do mundo ao fim do mundo o mesmo evento. Cada folha, de carvalho e freixo e espinheiro, ${ }^{126}$ é uma incorporação única do padrão, e para alguns este mesmo ano pode ser $a$ incorporação, a primeira jamais vista e reconhecida, embora carvalhos tenham gerado folhas por incontáveis gerações de homens.

Não nos desesperamos, ou não precisamos nos desesperar, de desenhar porque todas as linhas têm de ser retas ou curvas, nem de pintar porque há apenas três cores "primárias". Podemos de fato ser mais velhos agora, na medida em que somos herdeiros na apreciação ou na prática de muitas gerações de ancestrais nas artes. Nessa herança de riqueza pode haver um perigo de tédio ou de ansiedade de ser original, e isso pode levar a um desprezo pelo desenho preciso, o padrão delicado e as cores "bonitas", ou então à mera manipulação e superelaboração de material antigo, hábil e sem coração. Mas a verdadeira rota de escape de tal cansaço não pode ser encontrada no deliberadamente esquisito, tosco ou deformado, em tornar todas as coisas sombrias ou irredimivelmente violentas; nem na mistura de cores da sutileza ao desmazelo, e na fantástica complicação de formas até o ponto da tolice e adiante até o delírio. Antes de atingirmos tais estágios, precisamos de recuperação. Deveríamos olhar para o verde outra vez, e ser assombrados de novo (mas não cegados) pelo azul e amarelo e vermelho. Deveríamos encontrar o centauro e o dragão, e então talvez subitamente contemplar, como os antigos pastores, ovelhas, e cães, e cavalos - e lobos. Essa recuperação as estórias de fadas nos ajudam a fazer. Nesse sentido apenas o gosto por elas pode nos tornar, ou nos manter, infantis.

\footnotetext{
${ }^{126}$ Essa tríade de árvores é recorrente no folclore da Grã-Bretanha, e representa como que a totalidade do mundo natural - o número três tem a conotação de completude em inúmeras culturas. (N. do T.)
} 
Recovery (which includes return and renewal of health) is a re-gaining - regaining of a clear view. I do not say 'seeing things as they are' and involve myself with the philosophers, though I might venture to say 'seeing things as we are (or were) meant to see them' - as things apart from ourselves. We need, in any case, to clean our windows; so that the things seen clearly may be freed from the drab blur of triteness or familiarity - from possessiveness. Of all faces those of our familiares are the ones both most difficult to play fantastic tricks with, and most difficult really to see with fresh attention, perceiving their likeness and unlikeness: that they are faces, and yet unique faces. This triteness is really the penalty of 'appropriation': the things that are trite, or (in a bad sense) familiar, are the things that we have appropriated, legally or mentally. We say we know them. They have become like the things which once attracted us by their glitter, or their colour, or their shape, and we laid hands on them, and then locked them in our hoard, acquired them, and acquiring ceased to look at them.

Of course, fairy-stories are not the only means of recovery, or prophylactic against loss. Humility is enough. And there is (especially for the humble) Mooreeffoc, or Chestertonian Fantasy. Mooreeffoc is a fantastic word, but it could be seen written up in every town in this land. It is Coffee-room, viewed from the inside through a glass door, as it was seen by Dickens on a dark London day; and it was used by Chesterton to denote the queerness of things that have become trite, when they are seen suddenly from a new angle. That kind of 'fantasy' most people would allow to be wholesome enough; and it can never lack for material. But it has, I think, only a limited power; for the reason that recovery of freshness of vision is its only virtue. The word Mooreeffoc may cause you suddenly to realise that England is an utterly alien land, lost either in some remote past age glimpsed by history, or in some strange dim future to be reached only by a time-machine; to see the amazing oddity and interest of its inhabitants and their customs and feeding-habits; but it cannot do more than that: act as a time-telescope focused on one spot. Creative fantasy, because it is mainly trying to do something else (make something new), may open your hoard and let all the locked things fly away like cage-birds. The gems all 
A recuperação (que inclui o retorno e a renovação da saúde) é uma re-tomada retomada de uma visão clara. Não digo "ver as coisas como elas são" para não me envolver com os filósofos, embora eu pudesse arriscar dizer "ver as coisas como nós somos (ou fomos) destinados a vê-las" - como coisas separadas de nós mesmos. Precisamos, em todo o caso, limpar nossas janelas; de forma que as coisas vistas claramente possam ser libertadas do fosco borrão de banalidade ou de familiaridade de possessividade. De todos os rostos, aqueles de nossos familiares $^{127}$ são os mais difíceis com os quais realizar truques fantásticos, e os mais difíceis de realmente ver com atenção fresca, percebendo sua semelhança e dessemelhança: que eles são rostos, e contudo rostos únicos. Essa banalidade é, na verdade, o preço da "apropriação": as coisas que são banais ou (num mau sentido) familiares são as coisas das quais nos apropriamos, legal ou mentalmente. Dizemos que as conhecemos. Elas se tornaram como as coisas que uma vez nos atraíram por seu brilho, ou sua cor, ou sua forma, e deitamos mão sobre elas, e então as trancamos na nossa arca, as adquirimos, e ao adquiri-las cessamos de olhar para elas.

Claro, as estórias de fadas não são o único meio de recuperação, ou profilático contra a perda. Humildade é suficiente. E há (especialmente para os humildes) Éfac-edAsac, ou Fantasia Chestertoniana. Éfac-ed-Asac é uma palavra fantástica, mas podia ser lida em cada cidade desta terra. É Casa-de-café, vista de dentro, através de uma porta de vidro, como era vista por Dickens num dia escuro em Londres; e foi usada por Chesterton para denotar a esquisitice de coisas que se tornaram banais, quando elas são vistas repentinamente de um novo ângulo. Esse tipo de "fantasia" a maioria das pessoas concederá ser saudável o suficiente; e nunca pode ficar sem material. Mas ela tem, acho, apenas um poder limitado; pela razão de que uma recuperação do frescor da visão é sua única virtude. A palavra Éfac-ed-Asac pode levá-lo a repentinamente perceber que a Inglaterra é uma terra completamente alienígena, perdida em alguma remota era passada vislumbrada pela história, ou em algum estranho futuro impreciso a ser alcançado apenas por uma máquina do tempo; a ver a impressionante estranheza de seus habitantes e de seus costumes e hábitos alimentares; mas não pode fazer mais do que isso: agir como um telescópio do tempo enfocando um ponto. A fantasia criativa, porque está principalmente tentando fazer algo mais (fazer algo novo), pode abrir sua arca e deixar que todas as coisas trancadas voem para longe como pássaros da gaiola. As jóias todas

\footnotetext{
${ }^{127}$ Tolkien está usando a palavra latina no texto original - daí o itálico, embora ele perca boa parte de sua força em português. (N. do T.)
} 
turn into flowers or flames, and you will be warned that all you had (or knew) was dangerous and potent, not really effectively chained, free and wild; no more yours than they were you.

The 'fantastic' elements in verse and prose of other kinds, even when only decorative or occasional, help in this release. But not so thoroughly as a fairystory, a thing built on or about Fantasy, of which Fantasy is the core. Fantasy is made out of the Primary World, but a good craftsman loves his material, and has a knowledge and feeling for clay, stone and wood which only the art of making can give. By the forging of Gram cold iron was revealed; by the making of Pegasus horses were ennobled; in the Trees of the Sun and Moon root and stock, flower and fruit are manifested in glory.

And actually fairy-stories deal largely, or (the better ones) mainly, with simple or fundamental things, untouched by Fantasy, but these simplicities are made all the more luminous by their setting. For the story-maker who allows himself to be 'free with' Nature can be her lover not her slave. It was in fairy-stories that I first divined the potency of the words, and the wonder of the things, such as stone, and wood, and iron; tree and grass; house and fire; bread and wine.

I will now conclude by considering Escape and Consolation, which are naturally closely connected. Though fairy-stories are of course by no means the only medium of Escape, they are today one of the most obvious and (to some) outrageous forms of 'escapist' literature; and it is thus reasonable to attach to a consideration of them some consideration of this term 'escape' in criticism generally.

I have claimed that Escape is one of the main functions of fairy-stories, and since I do not disapprove of them, it is plain that I do not accept the tone of scorn or pity with which 'Escape' is now so often used: a tone for which the uses of the word outside literary criticism give no warrant at all. In what the misusers of Escape are fond of calling Real Life, Escape is evidently as a rule very practical, and may even be heroic. In real life it is difficult to blame it, unless it fails; in criticism it would seem to be the worse the better it succeeds. Evidently we are faced by a misuse of words, and also by a confusion of thought. Why should a man 
se tornam flores ou chamas, e você será advertido de que tudo o que tinha (ou conhecia) era perigoso e potente, não de verdade efetivamente acorrentado, livre e selvagem: não mais seu do que era você.

Os elementos "fantásticos" em verso e prosa de outros tipos, mesmo quando somente decorativos ou ocasionais, ajudam nessa liberação. Mas não tão diligentemente quanto uma estória de fadas, uma coisa construída sobre ou em torno da Fantasia, da qual a Fantasia é o centro. A Fantasia é feita do Mundo Primário, mas um bom artífice ama seu material, e tem um conhecimento e sensação de barro, pedra e madeira que só a arte de criar pode dar. Pela forja de $\operatorname{Gram}^{128}$ o ferro frio foi revelado; pela criação de Pégaso os cavalos foram enobrecidos; nas Árvores do Sol e da Lua ${ }^{129}$ raiz e tronco, flor e fruto são manifestos em glória.

E, na verdade, as estórias de fada lidam largamente, ou (as melhores) principalmente, com coisas simples ou fundamentais, intocadas pela Fantasia, mas essas simplicidades são tornadas ainda mais luminosas por seu cenário. Pois o criador de estórias que se permite ser "livre com" a Natureza pode ser seu amante, não seu escravo. Foi nas estórias de fadas que eu primeiro adivinhei a potência de palavras, e a maravilha de coisas, tais como pedra, e madeira, e ferro; árvore e grama; casa e fogo; pão e vinho.

Concluirei agora considerando Escape e Consolação, que por natureza estão proximamente ligados. Embora estórias de fadas não sejam, é claro, de forma alguma o único meio de Escape, elas são hoje umas das mais óbvias e (para alguns) ultrajantes formas de literatura "escapista"; e é, assim, razoável anexar a uma consideração delas algumas considerações desse termo "escape" na crítica em geral.

Afirmei que o Escape é uma das principais funções das estórias de fadas, e uma vez que não as desaprovo, está claro que não aceito o tom de escárnio e pena com o qual "Escape" é agora tão freqüentemente usado: um tom para o qual os usos da palavra fora da crítica literária não conferem garantia em absoluto. No que os maus usuários gostam de chamar de Vida Real, o Escape é evidentemente, via de regra, muito prático, e pode mesmo ser heróico. Na vida real é difícil culpá-lo, a menos que falhe; na crítica ele parece ser pior quanto melhor se dá. Evidentemente estamos confrontados com um mau uso de palavras, e também com uma confusão de pensamento. Por que dever-se-ia

\footnotetext{
${ }^{128}$ A espada de Sigurd dos Völsungs. (N. do T.)

${ }^{129}$ Uma referência discreta à própria mitologia de Tolkien em O Silmarillion, na qual as Árvores de Valinor dão origem ao Sol e à Lua. (N. do T.)
} 
be scorned, if, finding himself in prison, he tries to get our and go home? Or if, when he cannot do so, he thinks and talks about other topics than jailers and prison-walls? The world outside has not become less real because the prisoner cannot see it. In using Escape in this way the critics have chosen the wrong word, and, what is more, they are confusing, not always by sincere error, the Escape of the Prisoner with the Flight of the Deserter. Just so a Party-spokesman might have labelled departure from the misery of the Führer's or any other Reich and even criticism of it as treachery. In the same way these critics, to make confusion worse, and so to bring into contempt their opponents, stick their label of scorn not only on to Desertion, but on to real Escape, and what are often its companions, Disgust, Anger, Condemnation, and Revolt. Not only do they confound the escape of the prisoner with the flight of the deserter; but they would seem to prefer the acquiescence of the 'quisling' to the resistance of the patriot. To such thinking you have only to say 'the land you loved is doomed' to excuse any treachery, indeed to glorify it.

For a trifling instance: not to mention (indeed not to parade) electric street-lamps of mass-produced pattern in your tale is Escape (in that sense). But it may, almost certainly does, proceed from a considered disgust for so typical a product of the Robot Age, that combines elaboration and ingenuity of means with ugliness, and (often) with inferiority of result. These lamps may be excluded from the tale simply because they are bad lamps; and it is possible that one of the lessons to be learnt from the story is the realization of this fact. Bur out comes the big stick: 'Electric lamps have come to stay', they say. Long ago Chesterton truly remarked that, as soon as he heard that anything 'had come to stay', he knew that it would be very soon replaced - indeed regarded as pitiably obsolete and shabby. 'The march of Science, its tempo quickened by the needs of war, goes inexorably on . . . making some things obsolete, and foreshadowing new developments in the utilization of electricity': an advertisement. This says the same thing only more menacingly. The electric street-lamp may indeed be ignored, simply because it is so insignificant and transient. Fairy-stories, at any rate, have many more permanent and fundamental things to talk about. Lightning, for example. The escapist is not so subservient to the whims of evanescent fashion. as these opponents. He does not make things (which it may be quite rational 
escarnecer de um homem se, achando-se na prisão, ele tenta sair e ir para casa? Ou se, quando ele não pode fazê-lo, pensa e fala de outros temas que não carcereiros e paredes de prisão? O mundo lá fora não se tornou menos real porque o prisioneiro não consegue vê-lo. Ao usar escape dessa maneira, os críticos escolheram a palavra errada e, além do mais, estão confundindo, nem sempre por erro sincero, o Escape do Prisioneiro com a Fuga do Desertor. Bem assim um porta-voz do Partido poderia ter rotulado a partida da miséria do Reich do Führer, ou de qualquer outro Reich, ou mesmo a crítica contra ele, de traição. Da mesma maneira, esses críticos, para tornar a confusão pior, e assim levar ao desprezo os seus oponentes, colam seu rótulo de escárnio não apenas na Deserção, mas no Escape real, e no que freqüentemente são seus companheiros, Desgosto, Raiva, Condenação e Revolta. Não apenas confundem eles o escape do prisioneiro com a fuga do desertor; mas pareceriam preferir a aquiescência do "quisling" 130 à resistência do patriota. A tal pensamento você só precisa dizer "a terra que você amou está condenada" para desculpar qualquer traição, de fato para glorificá-la.

Por um insignificante exemplo: não mencionar (de fato, não alardear) lâmpadas elétricas de rua produzidas em massa no seu conto é Escape (nesse sentido). Mas pode vir, quase certamente vem, de uma aversão fundamentada a tão típico produto da Era Robô, que combina elaboração e engenhosidade de meios com feiúra, e (freqüentemente) com inferioridade de resultado. Essas lâmpadas podem ser excluídas do conto simplesmente porque são más lâmpadas; e é possível que uma das lições a serem aprendidas da estória é a percepção desse fato. Mas lá vem o porrete: "Lâmpadas elétricas vieram para ficar", dizem eles. Há muito Chesterton verdadeiramente observou que, assim que ele ouvia que qualquer coisa "tinha vindo para ficar", sabia que seria muito em breve substituída - de fato, considerada miseravelmente obsoleta e desmazelada. "A marcha da Ciência, seu ritmo apressado pelas necessidades da guerra, segue inexoravelmente... tornando algumas coisas obsoletas, e prenunciando novos desenvolvimentos na utilização da eletricidade": uma propaganda. Essa diz a mesma coisa, apenas mais ameaçadoramente. A lâmpada elétrica de rua pode, de fato, ser ignorada simplesmente porque é tão insignificante e transitória. As estórias de fadas, de qualquer maneira, têm coisas muito mais permanentes e fundamentais das quais falar. Relâmpago, por exemplo. O escapista não é tão subserviente aos caprichos da moda evanescente quanto esses opositores. Ele não faz de coisas (o que pode ser bem racional

\footnotetext{
${ }^{130}$ A palavra está dicionarizada em português, e se refere originalmente a Vidkun Quisling (1887-1945), o político e fundador do partido fascista norueguês que apoiou a invasão nazista em seu país.
} 
to regard as bad) his masters or his gods by worshipping them as inevitable, even 'inexorable'. And his opponents, so easily contemptuous, have no guarantee that he will stop there: he might rouse men to pull down the street-lamps. Escapism has another and even wickeder face: Reaction.

Not long ago - incredible though it may seem - I heard a clerk of Oxenford declare that he 'welcomed' the proximity of mass-production robot factories, and the roar of self-obstructive mechanical traffic, because it brought his university into 'contact with real life'. He may have meant that the way men were living and working in the twentieth century was increasing in barbarity at an alarming rate, and that the loud demonstration of this in the streets of Oxford might serve as a warning that it is not possible to preserve for long an oasis of sanity in a desert of unreason by mere fences, without actual offensive action (practical and intellectual). I fear he did not. In any case the expression 'real life' in this context seems to fall short of academic standards. The notion that motor-cars are more 'alive' than, say, centaurs or dragons is curious; that they are more 'real' than, say, horses is pathetically absurd. How real, how startlingly alive is a factory chimney compared with an elm tree: poor obsolete thing, insubstantial dream of an escapist!

For my part, I cannot convince myself that the roof of Bletchley station is more 'real' than the clouds. And as an artefact I find it less inspiring than the legendary dome of heaven. The bridge to platform 4 is to me less interesting than Bifröst guarded by Heimdall with the Gjallarhorn. From the wildness of my heart I cannot exclude the question whether railway-engineers, if they had been brought up on more fantasy, might not have done better with all their abundant means than they commonly do. Fairy-stories might be, I guess, better Masters of Arts than the academic person I have referred to. Much that he (I must suppose) and others (certainly) would call 'serious' literature is no more than play under a glass roof by the side of a municipal swimming-bath. 
considerar como ruim) seus mestres ou seus deuses adorando-as como inevitáveis, mesmo “inexoráveis". E seus oponentes, que tão facilmente o desprezam, não têm garantia alguma de que ele pare ali: ele pode estimular homens a arrancar as lâmpadas de rua. O Escapismo tem outra face ainda mais malvada: a Reação.

Não muito tempo atrás - por incrível que possa parecer - ouvi um amanuense ${ }^{131}$ de Oxenford declarar que ele "acolhia" a proximidade de fábricas-robôs de produção em massa, e o rugido do trânsito mecânico auto-obstrutivo, porque isso colocava sua universidade em "contato com a vida real". Ele poderia estar querendo dizer que a maneira como os homens estavam vivendo e trabalhando no século $\mathrm{XX}$ estava aumentando em barbárie num ritmo alarmante, e que a demonstração barulhenta disso nas ruas de Oxford poderia servir como um aviso de que não é possível preservar por muito tempo um oásis de sanidade num deserto de desrazão com meras cercas, sem verdadeira ação ofensiva (prática e intelectual). Temo que ele não tenha dito isso. De qualquer modo, a expressão "vida real" nesse contexto parece ficar aquém dos padrões acadêmicos. A noção de que carros motorizados sejam mais "vivos" do que, digamos, centauros ou dragões é curiosa; a de que eles sejam mais reais do que, digamos, cavalos é pateticamente absurda. Quão real, quão impressionantemente viva é uma chaminé de fábrica comparada a um álamo: pobre coisa obsoleta, sonho insubstancial de um escapista!

De minha parte, não consigo me convencer de que o teto da estação Bletchley seja mais "real" que as nuvens. E, como um artefato, eu o acho menos inspirador que o legendário domo do céu. A ponte para a plataforma 4 é, para mim, menos interessante que Bifröst guardada por Heimdall com o Gjallarhorn. Da selvageria de meu coração eu não consigo excluir a questão de saber se os engenheiros ferroviários, se tivessem sido criados com mais fantasia, não poderiam ter feito melhor com todos os seus meios abundantes do que eles geralmente fazem. Estórias de fadas poderiam ser, acho, melhores Mestres de Artes do que o sujeito acadêmico a quem me referi.

Muito do que ele (devo supor) e outros (certamente) chamariam de literatura "séria" não é mais do que brincar debaixo de um teto de vidro ao lado de uma piscina

\footnotetext{
${ }^{131}$ Mais uma teia complicada de sentidos emaranhados se acumula ao redor da palavra clerk, ainda mais quando Tolkien lhe dá conotação ironicamente arcaica com o emprego conjunto de Oxenford. Até onde foi possível investigar, nenhuma palavra em português tem a conotação vagamente eclesiástica do termo em inglês. "Amanuense" foi escolhido porque mantém a conexão latinizante e "escolástica" e, mais importante ainda, o sarcasmo que o autor destila nessa passagem.
} 
Fairy-stories may invent monsters that fly the air or dwell in the deep, but at least they do not try to escape from heaven or the sea.

And if we leave aside for a moment 'fantasy', I do not think that the reader or the maker of fairy-stories need even be ashamed of the 'escape' of archaism: of preferring not dragons but horses, castles, sailing-ships, bows and arrows; not only elves, but knights and kings and priests. For it is after all possible for a rational man, after reflection (quite unconnected with fairy-story or romance), to arrive at the condemnation, implicit at least in the mere silence of 'escapist' literature, of progressive things like factories, or the machine-guns and bombs that appear to be their most natural and inevitable, dare we say 'inexorable', products.

'The rawness and ugliness of modern European life' - that real life whose contact we should welcome - 'is the sign of a biological inferiority, of an insufficient or false reaction to environment. ${ }^{132}$ The maddest castle that ever came out of a giant's bag in a wild Gaelic story is not only much less ugly than a robot-factory, it is also (to use a very modern phrase) 'in a very real sense' a great deal more real. Why should we not escape from or condemn the 'grim Assyrian' absurdity of top-hats, or the Morlockian horror of factories? They are condemned even by the writers of that most escapist form of all literature, stories of Science fiction. These prophets often foretell (and many seem to yearn for) a world like one big glass-roofed railway-station. But from them it is as a rule very hard to gather what men in such a world-town will do. They may abandon the 'full Victorian panoply' for loose garments (with zip-fasteners), but will use this freedom mainly, it would appear, in order to play with mechanical toys in the soon-cloying game of moving at high speed. To judge by some of these tales they will still be as lustful, vengeful, and greedy as ever; and the ideals of their idealists hardly reach farther than the splendid notion of building more towns of the same sort on other planets. It is indeed an age of 'improved means to deteriorated ends'. It is part of the essential malady of such days producing the desire to escape, not indeed from life, but from our present time and

${ }^{132}$ Christopher Dawson, Progress and Religion, pp. 58, 59. Later he adds: 'The full Victorian panoply of top-hat and frock-coat undoubtedly expressed something essential in the nineteenthcentury culture, and hence it has with that culture spread all over the world, as no fashion of clothing has ever done before. It is possible that our descendants will recognise in it a kind of grim Assyrian beauty, fit emblem of the ruthless and great age that created it; but however that may be, it misses the direct and inevitable beauty that all clothing should have, because like its parent culture it was out of touch with the life of nature and of human nature as well.' 
municipal. Estórias de fadas podem inventar monstros que voam no ar ou habitam as profundezas, mas pelo menos elas não tentam escapar do céu ou do mar.

E se deixarmos de lado por um momento a "fantasia", não acho que o leitor ou criador de estórias de fadas precisem mesmo se envergonhar do "escape" do arcaísmo: de preferir não dragões mas cavalos, castelos, barcos a vela, arcos e flechas; não apenas elfos, mas cavaleiros e reis e sacerdotes. Pois é, afinal de contas, possível para um homem racional, depois de reflexão (bastante desligada de estória de fadas ou romance), chegar à condenação, implícita pelo menos no mero silêncio da literatura "escapista", de coisas progressistas como fábricas, ou as metralhadoras e bombas que parecem ser seus mais naturais e inevitáveis, ousaríamos dizer inexoráveis, produtos.

"A crueza e feiúra da vida européia moderna" - aquela vida real cujo contato nós deveríamos acolher - "é o sinal de uma inferioridade biológica, de uma reação insuficiente ou falsa ao ambiente. ${ }^{, 133} \mathrm{O}$ mais louco castelo que jamais saiu da bolsa de um gigante numa selvagem estória gaélica é não apenas muito menos feio que uma fábrica robotizada, ele também é (para usar uma frase muito moderna) "num sentido muito real" um bocado mais real. Por que não deveríamos escapar disso, ou condenar o absurdo "sombrio e assírio" das cartolas, ou o horror morlockiano das fábricas? Eles são condenados até pelos autores daquela forma mais escapista de toda a literatura, estórias de ficção científica. Esses profetas freqüentemente predizem (e muitos parecem ansiar por) um mundo semelhante a uma grande estação de trem com teto de vidro. Mas deles, via de regra, é muito difícil arrancar o que os homens em tal cidade-mundo vão fazer. Eles podem abandonar a "panóplia vitoriana completa" em favor de trajes largos (com zíperes), mas usarão essa liberdade principalmente, parece, para brincar com brinquedos mecânicos no jogo logo entediante de se mover em alta velocidade. A julgar por algumas dessa estórias, eles ainda serão tão luxurientos, vingativos e ambiciosos como sempre; e os ideais de seus idealistas dificilmente irão além da esplêndida noção de construir mais cidades do mesmo tipo em outros planetas. É de fato uma era de "meios melhorados para fins deteriorados". É parte da moléstia essencial de tais dias produzindo o desejo de escapar, não realmente da vida, mas da nossa presente época e

\footnotetext{
${ }^{133}$ Christopher Dawson, Progresso e Religião, págs. 58, 59. Mais tarde, ele acrescenta: “A panóplia vitoriana completa de cartola e fraque indubitavelmente expressava algo essencial na cultura do século XIX, e por isso, com essa cultura, espalhou-se pelo mundo todo, como nenhuma outra moda de vestuário havia feito antes. É possível que nossos descendentes reconheçam nela uma espécie de sombria beleza assíria, adequado emblema da grande e impiedosa era que a criou; mas, seja lá como for, ela perde a beleza direta e inevitável que todo vestuário deveria ter, porque, como a cultura que a gerou, estava sem contato com a vida da natureza e com a natureza humana também".
} 
self-made misery - that we are acutely conscious both of the ugliness of our works, and of their evil. So that to us evil and ugliness seem indissolubly allied. We find it difficult to conceive of evil and beauty together. The fear of the beautiful fay that ran through the elder ages almost eludes our grasp. Even more alarming: goodness is itself bereft of its proper beauty. In Faerie one can indeed conceive of an ogre who possesses a castle hideous as a nightmare (for the evil of the ogre wills it so), but one cannot conceive of a house built with a good purpose - an inn, a hostel for travellers, the hall of a virtuous and noble king - that is yet sickeningly ugly. At the present day it would be rash to hope to see one that was not - unless it was built before our time.

This, however, is the modern and special (or accidental) 'escapist' aspect of fairystories, which they share with romances and other stories out of or about the past. Many stories out of the past have only become 'escapist' in their appeal through surviving from a time when men were as a rule delighted with the work of their hands into our time when many men feel disgust with man-made things.

But there are also other and more profound 'escapisms' that have always appeared in fairy-tale and legend. There are other things more grim and terrible to fly from than the noise, stench, ruthlessness, and extravagance of the internal-combustion engine. There are hunger, thirst, poverty, pain, sorrow, injustice, death. And even when men are not facing hard things such as these, there are ancient limitations from which fairy-stories offer a sort of escape, and old ambitions and desires (touching the very roots of fantasy) to which they offer a kind of satisfaction and consolation. Some are pardonable weaknesses or curiosities: such as the desire to visit, free as a fish, the deep sea; or the longing for the noiseless, gracious, economical flight of a bird, that longing which the aeroplane cheats, except in rare moments, seen high and by wind and distance noiseless, turning in the sun: that is, precisely when imagined and not used. There are profounder wishes: such as the desire to converse with other living things. On this desire, as ancient as the Fall, is largely founded the talking of beasts and creatures in fairy-tales, and especially the magical understanding of their proper speech. This is the root, and not the 'confusion' attributed to the minds of men of the unrecorded past, an alleged 
auto-imposta miséria - que nós estejamos agudamente conscientes tanto da feiúra de nossas obras quanto de seu mal. De forma que para nós o mal e a feiúra parecem indissoluvelmente ligados. Achamos difícil conceber o mal e a beleza juntos. $\mathrm{O}$ medo da bela fada que perpassou as eras mais antigas quase elude a nossa percepção. Em Feéria pode-se de fato conceber um ogro que possui um castelo horrendo como um pesadelo (pois o mal do ogro o quer assim), mas não se pode conceber uma casa construída com um bom propósito - uma estalagem, um albergue para viajantes, o salão de um rei virtuoso e nobre - que ainda assim seja repulsivamente feia. No momento presente seria temerário esperar ver uma que não o fosse - a menos que tenha sido construída antes do nosso tempo.

Esse, entretanto, é o aspecto "escapista" moderno e especial (ou acidental) das estórias de fadas, que elas compartilham com romances, e com outras estórias do ou sobre o passado. Muitas estórias sobre o passado só se tornaram "escapistas" em seu apelo por sobreviverem de uma época em que os homens estavam, via de regra, deliciados com a obra de suas mãos, até nosso tempo, quando muitos homens sentem desgosto de coisas feitas pelo homem.

Mas há também outros e mais profundos "escapismos" que sempre apareceram nos contos de fadas e na lenda. Há outras coisas mais sombrias e terríveis das quais fugir do que o barulho, o fedor, a crueldade e a extravagância do motor de combustão interna. Há fome, sede, pobreza, dor, tristeza, injustiça, morte. E, mesmo quando os homens não estão enfrentando coisas duras como essas, há antigas limitações para as quais as estórias de fadas oferecem um tipo de escape, e velhas ambições e desejos (tocando as próprias raízes da fantasia) para as quais elas oferecem uma espécie de satisfação e consolação. Algumas são fraquezas ou curiosidades perdoáveis: tais como o desejo de visitar, livre como um peixe, o mar profundo; ou o anseio pelo vôo silencioso, gracioso, econômico de um pássaro, aquele anseio que o aeroplano frustra, exceto em raros momentos, visto no alto e por vento e distância silencioso, virando ao sol: isto é, precisamente quando imaginado e não usado. Há desejos mais profundos: tais como o desejo de conversar com outras coisas vivas. Sobre esse desejo, tão antigo quanto a Queda, está largamente fundamentada a fala de animais e criaturas nos contos de fadas, e especialmente a compreensão mágica de sua língua correta. Essa é a raiz, e não a "confusão" atribuída às mentes dos homens do passado não-registrado, uma suposta 
'absence of the sense of separation of ourselves from beasts'. ${ }^{134}$ A vivid sense of that separation is very ancient; but also a sense that it was a severance: a strange fate and a guilt lies on us. Other creatures are like other realms with which Man has broken off relations, and sees now only from the outside at a distance, being at war with them, or on the terms of an uneasy armistice. There are a few men who are privileged to travel abroad a little; others must be content with travellers' tales. Even about frogs. In speaking of that rather odd but widespread fairy-story The Frog King Max Müller asked in his prim way: 'How came such a story ever to be invented? Human beings were, we may hope, at all times sufficiently enlightened to know that a marriage between a frog and the daughter of a queen was absurd.' Indeed we may hope so! For if not, there would be no point in this story at all, depending as it does essentially on the sense of the absurdity. Folk-lore origins (or guesses about them) are here quite beside the point. It is of little avail to consider totemism. For certainly, whatever customs or beliefs about frogs and wells lie behind this story, the frog-shape was and is preserved in the fairy-story ${ }^{135}$ precisely because it was so queer and the marriage absurd, indeed abominable. Though, of course, in the versions which concern us, Gaelic, German, English, ${ }^{136}$ there is in fact no wedding between a princess and a frog: the frog was an enchanted prince. And the point of the story lies not in thinking frogs possible mates, but in the necessity of keeping promises (even those with intolerable consequences) that, together with observing prohibitions, runs through all Fairyland. This is one of the notes of the horns of Elfland, and not a dim note.

And lastly there is the oldest and deepest desire, the Great Escape: the Escape from Death. Fairy-stories provide many examples and modes of this - which might be called the genuine escapist, or (I would say) fugitive spirit. But so do other stories (notably those of scientific inspiration), and so do other studies. Fairystories are made by men not by fairies. The human stories

\footnotetext{
${ }^{134}$ See Note G at end.

${ }^{135}$ Or group of similar stories.

${ }^{136}$ The Queen who sought drink from a certain Well and the Lorgann (Campbell, xxiii); Der Froschkönig; The Maid and the Frog.
} 
"falta do senso de separação entre nós mesmos e os animais". ${ }^{137}$ Um senso vívido dessa separação é muito antigo; mas também o senso de que foi um rompimento: um fado estranho e uma culpa jazem sobre nós. Outras criaturas são como outros reinos com os quais o Homem rompeu relações, e vê agora somente de fora, à distância, estando em guerra com eles, ou nos termos de um armistício desconfortável. Há uns poucos homens que têm o privilégio de viajar para fora um pouco; outros têm de ficar contentes com estórias de viajantes. Mesmo sobre sapos. Ao falar daquela estória de fadas bem esquisita mas bastante distribuída, O Sapo-Rei, Max Muller perguntou de seu jeito direto: "Como é que tal estória jamais chegou a ser inventada? Os seres humanos, podemos esperar, foram em todas as épocas suficientemente educados para saber que um casamento entre um sapo e a filha de uma rainha era absurdo". De fato podemos esperar que sim! Pois, se não fosse assim, não haveria propósito na estória de forma alguma, dependendo como ela depende essencialmente do senso do absurdo. Origens folclóricas (ou suposições sobre elas) estão aqui totalmente fora de lugar. É de pouca valia considerar o totemismo. Pois, certamente, quaisquer que sejam os costumes ou crenças sobre sapos e poços que existam por trás dessa estória, a forma de sapo foi e é preservada na estória de fadas ${ }^{138}$ precisamente porque era tão esquisita e o casamento absurdo, de fato abominável. Embora, é claro, nas versões que nos dizem respeito, gaélicas, alemãs e inglesas, ${ }^{139}$ não haja realmente um casamento entre uma princesa e um sapo: o sapo era um príncipe encantado. E o propósito da estória não é achar sapos possíveis consortes, mas a necessidade de manter promessas (mesmo aquelas com conseqüências intoleráveis) que, junto com a observação de proibições, perpassa toda a Terra das Fadas. Essa é uma das notas das trompas da Terra dos Elfos, e não é uma nota tênue.

E, finalmente, há o mais antigo e profundo desejo, o Grande Escape: o Escape da Morte. As estórias de fadas provêm muitos exemplos e modos disso - o que poderia ser chamado o genuíno espírito escapista, ou (eu diria) fugitivo. Mas assim também fazem outras estórias (notavelmente aquelas de inspiração científica), e assim também fazem outros estudos. As estórias de fadas são feitas por homens, não por fadas. As estórias

\footnotetext{
${ }^{137}$ Ver Nota G no fim (pág. 26).

${ }^{138}$ Ou grupo de histórias similares.

${ }^{139}$ A Rainha que buscou bebida num certo Poço e o Lorgann (Campbell, xxiii); Der Froschkönig; A Donzela e o Sapo.
} 
of the elves are doubtless full of the Escape from Deathlessness. But our stories cannot be expected always to rise above our common level. They often do. Few lessons are taught more clearly in them than the burden of that kind of immortality, or rather endless serial living, to which the 'fugitive' would fly. For the fairy-story is specially apt to teach such things, of old and still today. Death is the theme that most inspired George MacDonald.

But the 'consolation' of fairy-stories has another aspect than the imaginative satisfaction of ancient desires. Far more important is the Consolation of the Happy Ending. Almost I would venture to assert that all complete fairy-stories must have it. At least I would say that Tragedy is the true form of Drama, its highest function; but the opposite is true of Fairy-story. Since we do not appear to possess a word that expresses this opposite - I will call it Eucatastrophe. The eucatastrophic tale is the true form of fairy-tale, and its highest function.

The consolation of fairy-stories, the joy of the happy ending: or more correctly of the good catastrophe, the sudden joyous 'turn' (for there is no true end to any fairytale): ${ }^{140}$ this joy, which is one of the things which fairy-stories can produce supremely well, is not essentially 'escapist', nor 'fugitive'. In its fairy-tale - or otherworld - setting, it is a sudden and miraculous grace: never to be counted on to recur. It does not deny the existence of dyscatastrophe, of sorrow and failure: the possibility of these is necessary to the joy of deliverance; it denies (in the face of much evidence, if you will) universal final defeat and in so far is evangelium, giving a fleeting glimpse of Joy, Joy beyond the walls of the world, poignant as grief.

It is the mark of a good fairy-story, of the higher or more complete kind, that however wild its events, however fantastic or terrible the adventures, it can give to child or man that hears it, when the 'turn' comes, a catch of the breath, a beat and lifting of the heart, near to (or indeed accompanied by) tears, as keen as that given by any form of literary art, and having a peculiar quality.

\footnotetext{
${ }^{140}$ See Note H at end (p. 80).
} 
humanas dos elfos ${ }^{141}$ estão sem dúvida cheias do Escape da Imortalidade. Mas nem sempre se pode esperar que nossas estórias se elevem além do nosso nível comum. Elas freqüentemente o fazem. Poucas lições são ensinadas mais claramente nelas do que o fardo desse tipo de imortalidade, ou melhor, vida continuada infinitamente, para o qual o "fugitivo" gostaria de fugir. Pois a estória de fadas é especialmente apta a ensinar tais coisas, outrora e ainda hoje. A morte é o tema que mais inspirou George MacDonald.

Mas a "consolação" dos contos de fadas tem outro aspecto além da satisfação imaginativa de antigos desejos. Muito mais importante é a Consolação do Final Feliz. Quase me aventuraria a afirmar que todas as estórias de fadas completas devem tê-lo. No mínimo, eu diria que a Tragédia é a verdadeira forma do Drama, sua mais alta função; mas o oposto é verdadeiro da Estória de Fadas. Já que não parecemos possuir uma palavra que expressa esse oposto, eu o chamarei de Eucatástrofe. O conto eucatastrófico é a verdadeira forma do conto de fadas, e sua mais alta função.

A consolação das estórias de fadas, a alegria do final feliz: ou, mais corretamente, o da boa catástrofe, a repentina "virada" alegre (pois não há fim verdadeiro para nenhuma estória de fadas): ${ }^{142}$ essa alegria, que é uma das coisas que as estórias de fadas produzem supremamente bem, não é essencialmente "escapista", nem "fugitiva". Em seu ambiente de conto de fadas - ou de outro mundo - , ela é uma graça repentina e miraculosa: nunca se pode contar que ela se repita. Ela não nega a existência da discatástrofe, da tristeza e do fracasso: a possibilidade delas é necessária para a alegria da libertação; ela nega (diante de muitas evidências, se você quiser) a derrota final universal, e nesse ponto é evangelium, dando um vislumbre fugidio de Alegria, Alegria além dos muros do mundo, pungente como tristeza.

É a marca de uma boa estórias de fadas, do tipo superior ou mais completo, que, por mais selvagens que sejam seus eventos, por mais fantásticas ou terríveis que sejam as aventuras, ela consegue dar a criança ou homem que a ouve, quando a "virada" vem, um prender da respiração, um bater e soerguer do coração, próximo (ou mesmo acompanhado) de lágrimas, tão penetrante quanto o dado por qualquer forma de arte literária, e possuidor de uma qualidade peculiar.

\footnotetext{
${ }^{141}$ Ou seja, as histórias sobre seres humanos criadas pelos elfos. A referência, mais uma vez muito discreta, vale para a própria mitologia tolkieniana: afinal, a história central dela, a saga de Beren e Lúthien, é justamente a de uma elfa que abandona a imortalidade para se casar com um humano. (N. do T.)

${ }^{142}$ Ver Nota H no fim (pág. 26).
} 
Even modern fairy-stories can produce this effect sometimes. It is not an easy thing to do; it depends on the whole story which is the setting of the turn, and yet it reflects a glory backwards. A tale that in any measure succeeds in this point has not wholly failed, whatever flaws it may possess, and whatever mixture or confusion of purpose. It happens even in Andrew Lang's own fairy-story, Prince Prigio, unsatisfactory in many ways as that is. When 'each knight came alive and lifted his sword and shouted "long live Prince Prigio"', the joy has a little of that strange mythical fairy-story quality, greater than the event described. It would have none in Lang's tale, if the event described were not a piece of more serious fairy-story 'fantasy' than the main bulk of the story, which is in general more frivolous, having the half-mocking smile of the courtly, sophisticated Conte. ${ }^{143}$ Far more powerful and poignant is the effect in a serious tale of Faerie. ${ }^{144}$ In such stories when the sudden 'turn' comes we get a piercing glimpse of joy, and heart's desire, that for a moment passes outside the frame, rends indeed the very web of story, and lets a gleam come through.

Seven long years I served for thee,

The glassy hill I clamb for thee,

The bluidy shirt I wrang for thee,

And wilt thou not wauken and turn to me?

He heard and turned to her. ${ }^{145}$

\section{EPILOGUE}

This 'joy' which I have selected as the mark of the true fairy-story (or romance), or as the seal upon it, merits more consideration.

Probably every writer making a secondary world, a fantasy, every sub-creator, wishes in some measure to be a real maker, or hopes that he is

\footnotetext{
${ }^{143}$ This is characteristic of Lang's wavering balance. On the surface the story is a follower of the 'courtly' French conte with a satiric twist, and of Thackeray's Rose and the Ring in particular - a kind which being superficial, even frivolous, by nature, does not produce or aim at producing anything so profound; but underneath lies the deeper spirit of the romantic Lang.

${ }_{144}^{144}$ Of the kind which Lang called 'traditional', and really preferred.

${ }^{145}$ The Black Bull of Norroway.
} 
Mesmo estórias de fadas modernas podem produzir esse efeito às vezes. Não é uma coisa fácil de fazer; depende da estória inteira que é o ambiente da virada, e contudo reflete uma glória por trás dela. Um conto que em qualquer medida tenha sucesso nesse ponto não fracassou completamente, seja lá que falhas possua, ou qualquer que seja a mistura ou confusão de propósito. Isso acontece até na própria estória de fadas de Andrew Lang, Príncipe Prígio, insatisfatória de muitas maneiras como é. Quando "cada cavaleiro surgiu vivo e levantou sua espada e gritou 'longa vida ao Príncipe Prígio" ", a alegria tem um pouco daquela estranha e mítica qualidade de estória de fadas, maior do que o evento descrito. Não haveria nada disso no conto de Lang se o evento descrito não fosse um trecho de "fantasia" de estória de fadas mais séria que o corpo principal da estória, que é em geral mais frívolo, tendo o sorriso meio zombeteiro do Conte sofisticado e cortesão. ${ }^{146}$ Muito mais poderoso e pungente é o efeito num conto sério de Feéria. ${ }^{147}$ Em tais estórias, quando a "virada" repentina vem, temos um vislumbre penetrante de alegria, e de desejo do coração, que por um momento passa por fora da moldura, rasga de fato a própria teia da estória, e deixa um brilho atravessar.

"Sete longos anos servi por $t i$,

A colina de vidro escalei por $t i$

A camisa sangrenta torci para $t i$

E não hás de te levantar e te voltar para mim?"

Ele ouviu e se voltou para ela. ${ }^{148}$

\section{EPÍLOGO}

Essa "alegria" que eu selecionei como a marca da verdadeira estória de fadas (ou romance), ou como o selo sobre ela, merece mais consideração.

Provavelmente todo escritor criando um mundo secundário, uma fantasia, todo sub-criador, deseja em alguma medida ser um verdadeiro criador, ou espera estar se

\footnotetext{
${ }^{146}$ Isso é característico do equilíbrio hesitante de Lang. Superficialmente, a história é seguidora do conte "cortesão" francês com um toque satírico, e em especial de Rosa e o Anel, de Thackeray - um estilo que, sendo superficial, e mesmo frívolo por natureza, não produz ou não almeja produzir nada tão profundo; mas sob tudo isso jaz o espírito mais profundo do romântico Lang.

${ }^{147}$ Do tipo que Lang chamava de "tradicional", e realmente preferia.
} 
drawing on reality: hopes that the peculiar quality of this secondary world (if not all the details $)^{149}$ are derived from Reality, or are flowing into it. If he indeed achieves a quality that can fairly be described by the dictionary definition: 'inner consistency of reality', it is difficult to conceive how this can be, if the work does not in some way partake of reality. The peculiar quality of the 'joy' in successful Fantasy can thus be explained as a sudden glimpse of the underlying reality or truth. It is not only a 'consolation' for the sorrow of this world, but a satisfaction, and an answer to that question, 'Is it true?' The answer to this question that I gave at first was (quite rightly): 'If you have built your little world well, yes: it is true in that world.' That is enough for the artist (or the artist part of the artist). But in the 'eucatastrophe' we see in a brief vision that the answer may be greater it may be a far-off gleam or echo of evangelium in the real world. The use of this word gives a hint of my epilogue. It is a serious and dangerous matter. It is presumptuous of me to touch upon such a theme; but if by grace what I say has in any respect any validity, it is, of course, only one facet of a truth incalculably rich: finite only because the capacity of Man for whom this was done is finite.

I would venture to say that approaching the Christian Story from this direction, it has long been my feeling (a joyous feeling) that God redeemed the corrupt making-creatures, men, in a way fitting to this aspect, as to others, of their strange nature. The Gospels contain a fairy-story, or a story of a larger kind which embraces all the essence of fairy-stories. They contain many marvels - peculiarly artistic, ${ }^{150}$ beautiful, and moving: 'mythical' in their perfect, self-contained significance; and among the marvels is the greatest and most complete conceivable eucatastrophe. But this story has entered History and the primary world; the desire and aspiration of sub-creation has been raised to the fulfilment of Creation. The Birth of Christ is the eucatastrophe of Man's history. The Resurrection is the eucatastrophe of the story of the Incarnation. This story begins and ends in joy. It has pre-eminently the 'inner consistency of reality'. There is no tale ever told that men would rather find was true, and none which so many sceptical men have accepted as true on its own merits. For the Art

\footnotetext{
148 O Touro Negro de Norroway.

${ }^{149}$ For all details may not be 'true': it is seldom that the 'inspiration' is so strong and lasting that it leavens all the lump, and does not leave much that is mere uninspired 'invention'.

${ }^{150}$ The Art is here in the story itself rather than in the telling; for the Author of the story was not the evangelists.
} 
inspirando na Realidade: espera que a qualidade peculiar desse mundo secundário (se não todos os detalhes $)^{151}$ sejam derivados da Realidade, ou estejam fluindo para ela. Se ele de fato consegue uma qualidade que possa razoavelmente ser descrita com a definição do dicionário, "consistência interna da realidade", é difícil conceber como isso possa ser, se a obra não, de alguma forma, partilhar da realidade. A qualidade peculiar da "alegria" na Fantasia bem-sucedida pode, assim, ser explicada como um vislumbre repentino da realidade ou verdade subjacente. Não é somente uma "consolação" para a tristeza deste mundo, mas uma satisfação, e uma resposta àquela questão, “É verdade?". A resposta a essa questão que eu dei a princípio foi (bastante acertadamente): "Se você construiu o seu pequeno mundo bem, sim: é verdade naquele mundo". Isso é suficiente para o artista (ou para a parte artista do artista). Mas na "eucatástrofe" vemos numa breve visagem que a resposta pode ser maior - pode ser um brilho ou eco distante de evangelium no mundo real. O uso dessa palavra dá alguma pista sobre meu epílogo. É uma matéria séria e perigosa. É presunçoso de minha parte tocar em tal tema; mas se por graça o que eu disse tem em qualquer respeito alguma validade, isso é, claro, só uma faceta de uma verdade incalculavelmente rica: finita somente porque a capacidade do Homem por quem isso foi feito é finita.

Eu me aventuraria a dizer que, abordando a Estória Cristã dessa direção, sempre foi meu sentimento (um sentimento alegre) que Deus redimiu as criaturas criadoras corruptas, os homens, numa maneira adequada a esse aspecto, assim como a outros, de sua estranha natureza. Os Evangelhos contêm uma estória de fadas, ou uma estória de um tipo maior que abraça toda a essência da estória de fadas. Eles contêm muitas maravilhas - peculiarmente artísticas, ${ }^{152}$ belas e comoventes: míticas em sua significância perfeita e autocontida; e entre as maravilhas está a maior e mais completa eucatástrofe concebível. Mas essa estória adentrou a História e o mundo primário; o desejo e a aspiração da sub-criação foram elevados à plenitude da Criação. $O$ Nascimento de Cristo é a eucatástrofe da história do Homem. A Ressurreição é a eucatástrofe da estória da Encarnação. Essa estória começa e termina em alegria. Tem preeminentemente a "consistência interna da realidade". Não há estória jamais contada que os homens tenham querido tanto que fosse verdadeira, e nenhuma que tantos homens céticos tenham aceitado como verdadeira em seus próprios méritos. Pois a Arte

\footnotetext{
${ }^{151}$ Pois nem todos os detalhes podem ser "verdadeiros": é raro que a "inspiração" seja tão forte e duradoura que supere toda a sobra, e não deixe muita coisa que é mera "invenção" não-inspirada.

${ }^{152}$ A Arte está aqui na história em si, e não no contar; pois o Autor da história não era os evangelistas.
} 
of it has the supremely convincing tone of Primary Art, that is, of Creation. To reject it leads either to sadness or to wrath.

It is not difficult to imagine the peculiar excitement and joy that one would feel, if any specially beautiful fairy-story were found to be 'primarily' true, its narrative to be history, without thereby necessarily losing the mythical or allegorical significance that it had possessed. It is not difficult, for one is not called upon to try and conceive anything of a quality unknown. The joy would have exactly the same quality, if not the same degree, as the joy which the 'turn' in a fairy-story gives: such joy has the very taste of primary truth. (Otherwise its name would not be joy.) It looks forward (or backward: the direction in this regard is unimportant) to the Great Eucatastrophe. The Christian joy, the Gloria, is of the same kind; but it is pre-eminently (infinitely, if our capacity were not finite) high and joyous. Because this story is supreme; and it is true. Art has been verified. God is the Lord, of angels, and of men - and of elves. Legend and History have met and fused.

But in God' s kingdom the presence of the greatest does not depress the small. Redeemed Man is still man. Story, fantasy, still go on, and should go on. The Evangelium has not abrogated legends; it has hallowed them, especially the 'happy ending'. The Christian has still to work, with mind as well as body, to suffer, hope, and die; but he may now perceive that all his bents and faculties have a purpose, which can be redeemed. So great is the bounty with which he has been treated that he may now, perhaps, fairly dare to guess that in Fantasy he may actually assist in the effoliation and multiple enrichment of creation. All tales may come true; and yet, at the last, redeemed, they may be as like and as unlike the forms that we give them as Man, finally redeemed, will be like and unlike the fallen that we know. 
dela tem o tom supremamente convincente da Arte Primária, isto é, da Criação. Rejeitála leva ou à tristeza ou à ira.

Não é difícil imaginar a excitação e a alegria peculiar que alguém sentiria se alguma estória de fadas especialmente bela se mostrasse ser "primariamente" verdadeira, sua narrativa ser história, sem, por meio disso, necessariamente perder a significância alegórica ou mítica que possuíra. Isso não é difícil, porque não se exige que se tente conceber qualquer coisa de uma qualidade desconhecida. A alegria teria exatamente a mesma qualidade, se não o mesmo grau, que a alegria a qual a "virada" numa estória de fadas dá: tal alegria tem o próprio sabor da verdade primária. (De outra forma o seu nome não seria alegria.) Ela olha adiante (ou atrás: a direção nesse respeito é desimportante) para a Grande Eucatástrofe. A alegria cristã, a Gloria, é do mesmo tipo; mas é preeminentemente (infinitamente, se nossa capacidade não fosse finita) elevada e alegre. Porque essa estória é suprema; e é verdadeira. A arte foi verifeita. Deus é o Senhor, de anjos, e de homens - e de elfos. Lenda e História se encontraram e fundiram.

Mas no reino de Deus a presença do maior não oprime o pequeno. O Homem redimido ainda é homem. Estória, fantasia, ainda continuam, e devem continuar. O Evangelium não abrrogou as lendas; ele as abençoou, especialmente o "final feliz". O cristão ainda tem de labutar, com mente e com corpo, para sofrer, esperar e morrer; mas ele pode agora perceber que todas as suas inclinações e faculdades têm um propósito, que pode ser redimido. Tão grande é a mercê com a qual ele foi tratado que pode agora, talvez, com razão ousar achar que na Fantasia ele pode, na verdade, assistir no florescimento e múltiplo enriquecimento da criação. Todas as estórias podem se tornar verdadeiras; e, contudo, no final, redimidas, elas podem ser tão semelhantes e dessemelhantes às formas que as damos quanto o Homem, finalmente redimido, será semelhante e dessemelhante ao caído que conhecemos. 


\section{NOTES}

A

The very root (not only the use) of their 'marvels' is satiric, a mockery of unreason; and the 'dream' element is not a mere machinery of introduction and ending, but inherent in the action and transitions. These things children can perceive and appreciate, if left to themselves. But to many, as it was to me, Alice is presented as a fairy-story and while this misunderstanding lasts, the distaste for the dream-machinery is felt. There is no suggestion of dream in The Wind in the Willows. 'The Mole had been working very hard all the morning, spring-cleaning his little house.' So it begins, and that correct tone is maintained. It is all the more remarkable that A. A. Milne, so great an admirer of this excellent book, should have prefaced to his dramatised version a 'whimsical' opening in which a child is seen telephoning with a daffodil. Or perhaps it is not very remarkable, for a perceptive admirer (as distinct from a great admirer) of the book would never have attempted to dramatise it. Naturally only the simpler ingredients, the pantomime, and the satiric beast-fable elements, are capable of presentation in this form. The play is, on the lower level of drama, tolerably good fun, especially for those who have not read the book; but some children that I took to see Tood of Tood Hall brought away as their chief memory nausea at the opening. For the rest they preferred their recollections of the book.

B

Of course, these details, as a rule, got into the tales, even in the days when they were real practices, because they had a story-making value. If I were to write a story in which it happened that a man was hanged, that might show in later ages, if the story survived - in itself a sign that the story possessed some permanent, and more than local or temporary, value - that it was written at a period when men were really hanged, as a legal practice. Might: the inference would not, of course, in that future time be certain.

For certainty on that point the future inquirer would have to know definitely when hanging was practised and when I lived. I could have borrowed the incident from other times and places, from other stories; I could simply have invented it. But even if this inference happened to be correct, the hanging-scene would only occur in the story, $(a)$ because I was aware of the dramatic, tragic, or macabre force of this incident in my tale, and $(b)$ because those who handed it down felt this force enough to make them keep the incident in. Distance of time, sheer antiquity and alienness, might later sharpen the edge of the tragedy or the horror; but the edge must be there even for the elvish hone of antiquity to whet it. The least useful question, therefore, for literary critics at any rate, to ask or to answer about Iphigeneia, daughter of Agamemnon, is: Does the legend of her sacrifice at Aulis come down from a time when human-sacrifice was commonly practised?

I say only 'as a rule', because it is conceivable that what is now regarded as a 'story' was once something different in intent: e.g. a record of fact or ritual. I mean 


\section{NOTAS}

A

A própria raiz (não apenas o uso) de suas maravilhas é satírica, um arremedo de desrazão; e o elemento de "sonho" não é uma mera maquinaria de introdução e final, mas inerente à ação e às transições. Essas coisas as crianças podem perceber e apreciar, se não as incomodarem. Mas para muitos, como foi para mim, Alice é apresentada como uma estória de fadas, e enquanto esse mal-entendido dura, o desgosto pela maquinaria de sonho é sentido. Não há sugestão nenhuma de sonho em $O$ Vento nos Salgueiros. "A Toupeira trabalhara duro a manhã toda, fazendo a limpeza de primavera em seu buraquinho." Assim ele começa, e esse tom correto é mantido. É ainda mais surpreendente que A.A. Milne, tão grande admirador desse livro excelente, tenha anexado à sua versão dramatizada uma abertura "maluca" na qual se vê uma criança telefonando para um narciso. Ou talvez não seja muito surpreendente, pois um admirador perceptivo (ao contrário de um grande admirador) do livro nunca teria tentado dramatizá-lo. Naturalmente, apenas os ingredientes mais simples, a pantomima e os elementos satíricos de fábula de animais são passíveis de apresentação nessa forma. A peça é, no nível inferior do drama, uma diversão toleravelmente boa, especialmente para aqueles que não leram o livro; mas algumas crianças que levei para ver Toad of Toad Hall levaram consigo como sua principal lembrança a náusea diante da abertura. De resto, elas preferiam suas recordações do livro.

B

É claro que esses detalhes, via de regra, entraram nos contos, mesmo nos dias em que eles eram práticas reais, porque tinham um valor para contar a estória. Se eu fosse escrever uma estória na qual acontecia de um homem ser enforcado, isso poderia mostrar, em épocas posteriores, se a estória sobrevivesse - em si mesmo um sinal de que a estória possuía algum valor permanente, ou mais do que local ou temporário -, que ela foi escrita num período em que os homens eram realmente enforcados, como uma prática legal. Poderia: a inferência não seria, é claro, certa naquele tempo futuro. Para a certeza sobre esse ponto, o investigador futuro teria de saber definitivamente quando o enforcamento era praticado e quando eu vivi. Eu poderia ter emprestado o incidente de outros tempos ou lugares; eu poderia tê-lo simplesmente inventado. Mas, mesmo se essa inferência acontecesse de estar correta, a cena de enforcamento só ocorreria na estória a)porque eu estava ciente da força dramática, trágica ou macabra desse incidente no meu conto e b)porque aqueles que o passaram adiante sentiram essa força suficientemente para fazê-los manter o incidente. Distância no tempo, pura antigüidade e estranheza poderiam mais tarde afiar o gume da tragédia ou do horror; mas o gume precisa estar lá para que mesmo o amolador élfico da antigüidade o afie. A questão menos útil, portanto, para os críticos literários, pelo menos, a se perguntar ou responder sobre Ifigênia, filha de Agamêmnon, é: a lenda de seu sacrifício em Áulis vem de um tempo em que o sacrifício humano era comumente praticado?

Digo apenas "via de regra" porque é concebível que o que agora é considerado como uma “estória” tenha sido antes algo diferente em intento: e.g. um registro de fato ou ritual. Quero dizer 
'record' strictly. A story invented to explain a ritual (a process that is sometimes supposed to have frequently occurred) remains primarily a story. It takes form as such, and will survive (long after the ritual evidently) only because of its story-values. In some cases details that now are notable merely because they are strange may have once been so everyday and unregarded that they were slipped in casually: like mentioning that a man 'raised his hat', or 'caught a train'. But such casual details will not long survive change in everyday habits.

Not in a period of oral transmission. In a period of writing (and of rapid changes in habits) a story may remain unchanged long enough for even its casual details to acquire the value of quaintness or queerness. Much of Dickens now has this air. One can open today an edition of a novel of his that was bought and first read when things were so in everyday life as they are in the story, though these everyday details are now already as remote from our daily habits as the Elizabethan period. But that is a special modem situation. The anthropologists and folk-lorists do not imagine any conditions of that kind. But if they are dealing with unlettered oral transmission, then they should all the more reflect that in that case they are dealing with items whose primary object was storybuilding, and whose primary reason for survival was the same. The Frog King is not a Credo, nor a manual of totem-law: it is a queer tale with a plain moral.

$\mathrm{C}$

As far as my knowledge goes, children who have an early bent for writing have no special inclination to attempt the writing of fairy-stories, unless that has been almost the sole form of literature presented to them; and they fail most markedly when they try. It is not an easy form. If children have any special leaning it is to Beast-fable, which adults often confuse with Fairy-story. The best stories by children that I have seen have been either 'realistic' (in intent), or have had as their characters animals and birds, who were in the main the zoomorphic human beings usual in Beast-fable. I imagine that this form is so often adopted principally because it allows a large measure of realism: the representation of domestic events and talk that children really know. The form itself is, however, as a rule, suggested or imposed by adults. It has a curious preponderance in the literature, good and bad, that is nowadays commonly presented to young children: I suppose it is felt to go with 'Natural History', semi-scientific books about beasts and birds that are also considered to be proper pabulum for the young. And it is reinforced by the bears and rabbits that seem in recent times almost to have ousted human dolls from the playrooms even of little girls. Children make up sagas, often long and elaborate, about their dolls. If these are shaped like bears, bears will be the characters of the sagas; but they will talk like people.

I was introduced to zoology and palaeontology ('for children') quite as early as to Faerie. I saw pictures of living beasts and of true (so I was told) prehistoric animals. I liked 
"registro" estritamente. Uma estória inventada para explicar um ritual (um processo que às vezes se supõe ter freqüentemente ocorrido) permanece primariamente uma estória. Toma forma como tal, e sobreviverá (muito depois do ritual, evidentemente) apenas por causa de seus valores de estória. Em alguns casos, detalhes que agora são notáveis meramente porque são estranhos podem certa vez ter sido tão quotidianos e desconsiderados que foram incluídos casualmente: como mencionar que um homem "levantou seu chapéu", ou "pegou um trem". Mas tais detalhes casuais não sobreviverão muito tempo à mudança nos hábitos quotidianos. Não num período de transmissão oral. Num período de escrita (e de mudança rápida nos hábitos), uma estória pode permanecer inalterada por tempo suficiente para que até seus detalhes casuais adquiram valor de excentricidade ou estranheza. Muito de Dickens agora tem esse ar. Pode-se abrir hoje uma edição de seus romances que foi comprada e lida pela primeira vez quando as coisas eram na vida quotidiana como são na estória, embora esses detalhes quotidianos sejam agora tão distantes dos nossos hábitos diários quanto o período elizabetano. Mas essa é uma condição especial moderna. Os antropólogos e folcloristas não imaginam nenhuma condição desse tipo. Mas, se estão lidando com transmissão oral iletrada, então deveriam ainda mais refletir que nesse caso estão lidando com itens cujo objetivo primário era a construção da estória, e cuja razão primária para sobreviver era a mesma. O SapoRei não é um Credo, nem um manual de lei totêmica: é uma estória esquisita com uma moral clara.

$\mathrm{C}$

Até onde o meu conhecimento vai, as crianças que têm uma inclinação precoce pela escrita não têm nenhuma inclinação especial para tentar a escrita de estórias de fadas, a menos que essa tenha sido quase que a única forma de literatura apresentada a elas; e elas falham muito claramente quando tentam. Não é uma forma fácil. Se as crianças têm alguma inclinação especial, é pela fábula de animais, que os adultos freqüentemente confundem com estória de fadas. As melhoras estórias de crianças que eu vi foram ou "realistas" (em intento), ou tinham como seus personagens animais e pássaros, que eram no geral os seres humanos zoomórficos usuais na fábula de animais. Imagino que essa forma seja tão freqüentemente adotada principalmente porque permite uma larga medida de realismo: a representação de eventos e conversa domésticos que as crianças realmente conhecem. A forma em si é, entretanto, sugerida ou imposta por adultos. Ela tem uma preponderância na literatura, boa ou má, que é hoje em dia comumente apresentada a crianças pequenas: suponho que sintam que ela acompanha a "História Natural", livros semi-científicos que também são considerados pabulum apropriado para os jovens. E é reforçada pelos ursos e coelhos que parecem, em tempos recentes, quase ter enxotado as bonecas humanas até dos quartos de brinquedo de garotinhas. Crianças inventam sagas, freqüentemente longas e elaboradas, sobre seus bonecos. Se eles têm forma de urso, ursos serão os personagens das sagas; mas eles falarão como pessoas.

D

Fui apresentado à zoologia e à paleontologia ("para crianças") quase tão cedo quanto a Feéria. Eu via figuras de bichos vivos e de verdadeiros (assim me era dito) animais pré-históricos. Eu gostava 
the 'prehistoric' animals best: they had at least lived long ago, and hypothesis (based on somewhat slender evidence) cannot avoid a gleam of fantasy. But I did not like being told that these creatures were 'dragons'. I can still re-feel the irritation that I felt in childhood at assertions of instructive relatives (or their gift-books) such as these: 'snowflakes are fairy jewels', or 'are more beautiful than fairy jewels'; 'the marvels of the ocean depths are more wonderful than fairyland'. Children expect the differences they feel but cannot analyse to be explained by their elders, or at least recognized, not to be ignored or denied. I was keenly alive to the beauty of 'Real things', but it seemed to me quibbling to confuse this with the wonder of 'Other things'. I was eager to study Nature, actually more eager than I was to read most fairy-stories; but I did not want to be quibbled into Science and cheated out of Faerie by people who seemed to assume that by some kind of original sin I should prefer fairy-tales, but according to some kind of new religion I ought to be induced to like science. Nature is no doubt a life-study, or a study for eternity (for those so gifted); but there is a part of man which is not 'Nature', and which therefore is not obliged to study it, and is, in fact, wholly unsatisfied by it.

E

There is, for example, in surrealism commonly present a morbidity or un-ease very rarely found in literary fantasy. The mind that produced the depicted images may often be suspected to have been in fact already morbid; yet this is not a necessary explanation in all cases. A curious disturbance of the mind is often set up by the very act of drawing things of this kind, a state similar in quality and consciousness of morbidity to the sensations in a high fever, when the mind develops a distressing fecundity and facility in figure-making, seeing forms sinister or grotesque in all visible objects about it.

I am speaking here, of course, of the primary expression of Fantasy in 'pictorial' arts, not of 'illustrations'; nor of the cinematograph. However good in themselves, illustrations do little good to fairy-stories. The radical distinction between all art (including drama) that offers a visible presentation and true literature is that it imposes one visible form. Literature works from mind to mind and is thus more progenitive. It is at once more universal and more poignantly particular. If it speaks of bread or wine or stone or tree, it appeals to the whole of these things, to their ideas; yet each hearer will give to them a peculiar personal embodiment in his imagination. Should the story say 'he ate bread', the dramatic producer or painter can only show 'a piece of bread' according to his taste or fancy, bur the hearer of the story will think of bread in general and picture it in some form of his own. If a story says 'he climbed a hill and saw a river in the valley below', the illustrator may catch, or nearly catch, his own vision of such a scene; bur every hearer of the words will have his own picture, and it will be made out of all the hills and rivers and dales he has ever seen, bur specially our of The Hill, The River, The Valley which were for him the first embodiment of the word.

F 
mais dos animais "pré-históricos": eles pelo menos tinham vivido há muito tempo, e a hipótese (baseada em evidências um tanto tênues) não consegue evitar um lampejo de fantasia. Mas eu não gostava de ouvir que essas criaturas eram "dragões". Ainda posso re-sentir a irritação que sentia na infância com as asserções de parentes instrutivos (ou os livros que davam de presente), tais como essas: "flocos de neve são jóias de fadas", ou "são mais bonitos que jóias de fadas"; "as maravilhas das profundezas do oceano são mais maravilhosas que a terra das fadas". As crianças esperam que as diferenças que sentem, mas não conseguem analisar, sejam explicadas pelos mais velhos, ou ao menos reconhecidas, não ignoradas ou negadas. Eu estava fortemente alerta diante da beleza das "Coisas reais", mas me parecia enganoso confundi-la com o assombro das "Outras coisas". Eu estava ansioso para estudar a Natureza, na verdade mais ansioso do que estava para ler a maioria das estórias de fadas; mas não queria ser desviado para a Ciência e ludibriado para longe de Feéria por pessoas que pareciam assumir que, por algum tipo de pecado original, eu preferiria estórias de fadas, mas, de acordo com algum tipo de nova religião, eu deveria ser induzido a gostar de ciência. A Natureza é sem dúvida um estudo para a vida, ou um estudo para a eternidade (para aqueles assim dotados); mas há uma parte do homem que não é "Natureza", e que portanto não é obrigada a estudá-la, e fica, de fato, completamente insatisfeita com ela.

$\mathrm{E}$

É, por exemplo, muito comum no surrealismo uma morbidez ou desassossego raramente encontrados na fantasia literária. A mente que produziu as imagens representadas pode freqüentemente ser suspeita de já ser realmente mórbida; mas isso não é uma explicação necessária em todos os casos. Um curioso distúrbio da mente é freqüentemente desencadeado pelo próprio ato de desenhar coisas desse tipo, coisa similar em qualidade e consciência da morbidez às sensações numa febre alta, quando a mente desenvolve uma inquietante fecundidade e facilidade na criação de figuras, vendo formas sinistras ou grotescas em todos os objetos visíveis em torno dela.

Estou falando aqui, é claro, da expressão primária da Fantasia em artes "pictóricas”, não de ilustrações; nem do cinematógrafo. Por mais que sejam boas em si mesmas, ilustrações fazem pouco bem a estórias de fadas. A distinção radical entre toda arte (inclusive o drama) que oferece uma representação visível e a literatura verdadeira é que ela impõe uma forma visível. A literatura funciona de mente a mente e é assim mais progenitiva. É ao mesmo tempo mais universal e mais pungentemente particular. Se fala de pão ou vinho ou pedra ou árvore, apela para o conjunto dessas coisas, para suas idéias; mas cada ouvinte dará a elas uma incorporação peculiar e pessoal em sua imaginação. Se a estória tivesse de dizer “ele comeu pão", o produtor dramático ou o pintor só podem mostrar um "pedaço de pão” de acordo com seu gosto ou capricho, mas o ouvinte da estória pensará em pão no geral e o retratará de alguma forma própria dele. Se uma estória diz “ele subiu uma colina e viu um rio no vale lá embaixo", o ilustrador pode capturar, ou quase capturar, sua própria visão de uma tal cena; mas cada ouvinte das palavras terá sua própria pintura, e ela será feita de todas as colinas e rios e vales que ele jamais viu, mas especialmente d'A Colina, O Rio, O Vale que foram para ele a primeira incorporação da palavra. 
I am referring, of course, primarily to fantasy of forms and visible shapes. Drama can be made out of the impact upon human characters of some event of Fantasy, or Faerie, that requires no machinery, or that can be assumed or reported to have happened. But that is not fantasy in dramatic result; the human characters hold the stage and upon them attention is concentrated. Drama of this sort (exemplified by some of Barrie's plays) can be used frivolously, or it can be used for satire, or for conveying such 'messages' as the playwright may have in his mind - for men. Drama is anthropocentric. Fairy-story and Fantasy need not be. There are, for instance, many stories telling how men and women have disappeared and spent years among the fairies, without noticing the passage of time, or appearing to grow older. In Mary Rose Barrie wrote a play on this theme. No fairy is seen. The cruelly tormented human beings are there all the time. In spite of the sentimental star and the angelic voices at the end (in the printed version) it is a painful play, and can easily be made diabolic: by substituting (as I have seen it done) the elvish call for 'angel voices' at the end. The non-dramatic fairy-stories, in so far as they are concerned with the human victims, can also be pathetic or horrible. Bur they need not be. In most of them the fairies are also there, on equal terms. In some stories they are the real interest. Many of the short folk-lore accounts of such incidents purport to be just pieces of 'evidence' about fairies, items in an agelong accumulation of 'lore' concerning them and the modes of their existence. The sufferings of human beings who come into contact with them (often enough, wilfully) are thus seen in quite a different perspective. A drama could be made about the sufferings of a victim of research in radiology, but hardly about radium itself. But it is possible to be primarily interested in radium (nor radiologists) - or primarily interested in Faerie, not tortured mortals. One interest will produce a scientific book, the other a fairy-story. Drama cannot well cope with either.

G

The absence of this sense is a mere hypothesis concerning men of the lost past, whatever wild confusions men of today, degraded or deluded, may suffer. It is just as legitimate an hypothesis, and one more in agreement with what little is recorded concerning the thoughts of men of old on this subject, that this sense was once stronger. That fantasies which blended the human form with animal and vegetable forms, or gave human faculties to beasts, are ancient is, of course, no evidence for confusion at all. It is, if anything, evidence to the contrary. Fantasy does not blur the sharp outlines of the real world; for it depends on them. As far as our western, European, world is concerned, this 'sense of separation' has in fact been attacked and weakened in modem times not by fantasy but by scientific theory. Not by stories of centaurs or werewolves or enchanted bears, but by the hypotheses (or dogmatic guesses) of scientific writers who classed Man not only as 'an animal' - that correct classification is ancient - but as 'only an animal'. There has been a consequent distortion of sentiment. The natural love of men not wholly corrupt for beasts, and the human desire to 'get inside the skin' of living things, 
Estou me referindo, é claro, primariamente à fantasia de formas e traços visíveis. O Drama pode ser feito do impacto sobre personagens humanos de algum evento de Fantasia, ou Feéria, que não requeira nenhuma maquinaria, ou que se possa assumir ou relatar que tenha acontecido. Mas isso não é fantasia em resultado dramático; os personagens humanos dominam o palco e sobre eles a atenção é concentrada. $\mathrm{O}$ Drama desse tipo (exemplificado por algumas das peças de Barrie) pode ser usado frivolamente, ou pode ser usado para sátira, ou para passar as "mensagens" que o dramaturgo possa ter na sua mente - para os homens. O Drama é antropocêntrico. A estória de fadas e a fantasia não precisam ser. Há, por exemplo, muitas estórias contando como homens e mulheres desapareceram e passaram anos entre as fadas, sem notar a passagem do tempo, ou sem parecer ficarem mais velhos. Em Mary Rose Barrie escreveu uma peça sobre esse tema. Nenhuma fada é vista. Os seres humanos cruelmente atormentados estão lá o tempo todo. Apesar da estrela sentimental e das vozes angélicas no fim (na versão impressa), é uma peça dolorosa, e pode facilmente se tornar diabólica: ao substituir (como eu vi ser feito) o chamado élfico por “vozes de anjo" no fim. As estórias de fadas não-dramáticas, até onde dizem respeito às vítimas humanas, também podem ser patéticas ou horríveis. Mas não precisam ser. Na maioria delas as fadas também estão lá, em termos iguais. Em algumas estórias elas são o verdadeiro interesse. Muitos dos relatos folclóricos curtos de tais incidentes pretendem ser apenas fragmentos de "evidências" sobre as fadas, itens num acúmulo secular de "sabedoria" acerca delas e dos modos de sua existência. Os sofrimentos dos seres humanos que entram em contato com elas (com freqüência apreciável, voluntariamente) são, assim, vistos numa perspectiva bem diferente. Poderia ser feita uma peça sobre os sofrimentos de uma vítima da pesquisa em radiologia, mas dificilmente sobre o próprio rádio. Mas é possível estar primariamente interessado em rádio (não em radiologistas) - ou primariamente interessado em Feéria, não em mortais torturados. Um interesse produzirá um livro científico, o outro uma estória de fadas. O drama não consegue lidar com nenhum dos dois.

A falta desse senso é uma mera hipótese acerca dos homens do passado perdido, seja lá de que confusões selvagens os homens de hoje, degradados ou iludidos, possam sofrer. É uma hipótese tão legítima quanto, e em maior concordância com o pouco que está registrado acerca dos pensamentos dos homens de outrora sobre esse assunto, que esse sentimento de separação era antes mais forte. Que as fantasias que mesclavam a forma humana com formas vegetais ou animais, ou que davam faculdades humanas às feras sejam antigas não é, claro, evidência alguma de confusão. É, se significa algo, evidência do contrário. A fantasia não embaça os contornos claros do mundo real; pois depende deles. No que concerne ao nosso mundo ocidental, europeu, esse "senso de separação" tem sido, de fato, atacado e enfraquecido não por fantasia, mas por teoria científica. Não por estórias de centauros ou lobisomens ou ursos encantados, mas pelas hipóteses (ou suposições dogmáticas) dos autores científicos que classificaram o Homem não apenas como "um animal" - essa classificação correta é antiga - mas como "apenas um animal". Tem havido uma conseqüente distorção de sentimento. O amor natural do homem não totalmente corrupto pelos animais, e o desejo humano de "entrar debaixo da pele" das coisas vivas, 
has run riot. We now get men who love animals more than men; who pity sheep so much that they curse shepherds as wolves; who weep over a slain warhorse and vilify dead soldiers. It is now, not in the days when fairy-stories were begotten, that we get 'an absence of the sense of separation'.

H

The verbal ending - usually held to be as typical of the end of fairy-stories as 'once upon a time' is of the beginning - 'and they lived happily ever after' is an artificial device. It does not deceive anybody. End-phrases of this kind are to be compared to the margins and frames of pictures, and are no more to be thought of as the real end of any particular fragment of the searnless Web of Story than the frame is of the visionary scene, or the casement of the Outer World. These phrases may be plain or elaborate, simple or extravagant, as artificial and as necessary as frames plain, or carved, or gilded. 'And if they have not gone away they are there still.' 'My story is done - see there is a little mouse; anyone who catches it may make himself a fine fur cap of it.' 'And they lived happily ever after.' 'And when the wedding was over, they sent me home with little paper shoes on a causeway of pieces of glass.' Endings of this sort suit fairy-stories, became such tales have a greater sense and grasp of the endlessness of the World of Story than most modern 'realistic' stories, already hemmed within the narrow confines of their own small time. A sharp cut in the endless tapestry is not unfittingly marked by a formula, even a grotesque or comic one. It was an irresistible development of modern illustration (so largely photographic) that borders should be abandoned and the 'picture' end only with the paper. This method may be suitable for photographs; but it is altogether inappropriate for the pictures that illustrate or are inspired by fairy-stories. An enchanted forest requires a margin, even an elaborate border. To print it conterminous with the page, like a 'shot' of the Rockies in Picture Post, as if it were indeed a 'snap' of fairyland or a 'sketch by our artist on the spot', is a folly and an abuse.

As for the beginnings of fairy-stories: one can scarcely improve on the formula Once upon a time. It has an immediate effect. This effect can be appreciated by reading, for instance, the fairy-story The Terrible Head in the Blue Fairy Book. It is Andrew Lang's own adaptation of the story of Perseus and the Gorgon. It begins 'once upon a time', and it does not name any year or land or person. Now this treatment does something which could be called 'turning mythology into fairystory'. I should prefer to say that it turns high fairy-story (for such is the Greek tale) into a particular form that is at present familiar in our land: a nursery or 'old wives' form. Namelessness is not a virtue but an accident, and should not have been imitated; for vagueness in this regard is a debasement, a corruption due to forgetfulness and lack of skill. But not so, I think, the timelessness. That beginning is not poverty-stricken but significant. It produces at a stroke the sense of a great uncharted world of time. 
ficou desgovernado. Agora temos homens que amam animais mais do que homens; que têm tanta pena de ovelhas que amaldiçoam pastores como lobos; que choram por um cavalo de guerra morto e vilificam soldados falecidos. É agora, não nos dias em que as estórias de fadas foram engendradas, que temos "uma falta do senso de separação".

$\mathrm{H}$

O final verbal - normalmente considerado como tão típico do fim de estórias de fadas quanto “era uma vez" é do começo - "e eles viveram felizes para sempre” é uma tática artificial. Não engana ninguém. Frases finais desse tipo devem ser comparadas às margens e molduras de pinturas, e não devem ser pensadas como o final verdadeiro de qualquer fragmento particular da inconsútil Teia da Estória mais do que a moldura é o da cena visionária, ou o estojo do Mundo Exterior. Essas frases podem ser despojadas ou elaboradas, simples ou extravagantes, tão artificiais e tão necessárias quanto molduras despojadas, ou esculpidas, ou douradas. "E se eles não foram embora, estão lá ainda." "Minha estória acabou - vê, ali está um ratinho; quem quer que o pegue pode fazer para si um gorro fino de pêlo com ele." "E eles viveram felizes para sempre." "E quando o casamento acabou, eles me mandaram para casa com sapatinhos de papel sobre uma rampa de pedaços de vidro."

Finais dessa sorte são adequados a estórias de fadas, porque tais contos têm um sentido e percepção maiores da infinitude do Mundo da Estória do que a maioria das modernas estórias "realistas", já apertadas dentro dos confins estreitos de seu próprio tempo pequeno. Um corte brusco na tapeçaria sem-fim é marcado de forma não inadequada por uma fórmula, mesmo que grotesca ou cômica. Foi um desenvolvimento irresistível da ilustração moderna (tão largamente fotográfica) que as bordas fossem abandonadas e a "pintura" terminasse apenas com o papel. Esse método pode ser adequado para fotografias; mas é de todo inapropriado para as pinturas que ilustram ou são inspiradas por estórias de fadas. Uma floresta encantada requer uma margem, mesmo uma borda elaborada. Imprimi-la no mesmo espaço da página, como uma "tomada" das Rochosas em Picture Post, como se fosse, de fato, um “instantâneo" da terra das fadas ou um "rascunho de nosso artista no local" é uma insensatez e um abuso.

Quanto aos inícios das estórias de fadas: dificilmente pode-se melhorar a fórmula Era uma vez. Ela tem um efeito imediato. Esse efeito pode ser apreciado ao ler, por exemplo, a estória de fadas $A$ Cabeça Terrivel no Blue Fairy Book. É a adaptação do próprio Andrew Lang da estória de Perseu e da Górgona. Começa com “era uma vez”, e não nomeia qualquer ano, terra ou pessoa. Ora, esse tratamento faz algo que poderia ser chamado de "transformar mitologia em estória de fadas". Eu preferiria dizer que ele transforma estória de fadas elevada (pois isso é o conto grego) numa forma particular que é, no presente, familiar na nossa terra: uma forma de berçário ou de "velhas amas". A falta de nomes não é uma virtude, mas um acidente, e não deveria ter sido imitada; pois a vagueza, nesse respeito, é uma degradação, uma corrupção devida ao esquecimento e à falta de perícia. Mas não é assim, acho, com a atemporalidade. Esse começo não é acometido pela pobreza, mas significativo. Ele produz de um golpe a sensação de um grande mundo não-mapeado de tempo. 


\section{Mythopoeia}

O primeiro fato interessante a levar em conta sobre o poema Mythopoeia é que, como já mencionamos acima, uma estrofe dele aparece, inteira (a única modificação é a expressão 'Caro senhor' no começo do primeiro verso, para adaptá-la ao estilo epistolar) em On fairy-stories. De fato, ambos os textos usam linguagens diferentes para elaborar a mesma profissão de fé literária e pessoal. É nesse par de textos que o autor deixa mais claro o seu projeto de uma nova literatura fantástica e, mais que isso, sua visão mística da criação literária como "sub-criação", ou seja, como a contribuição humana à Criação divina. Tal perspectiva, em grande medida despertada pela profunda fé católica de Tolkien, vê o "fazer dos mitos" (tradução do grego latinizado Mythopoeia do título) como a mais autêntica atividade humana, em contraposição aos esforços vãos (quando não totalmente perversos) de escravizar a natureza por meio da tecnologia.

Como a maioria das obras tolkienianas, Mythopoeia tem uma história textual complexa e ramificada, que não vem ao caso esmiuçar aqui - Tolkien parece ter sido incapaz de escrever qualquer coisa sem deixar pelo menos cinco ou seis manuscritos diferentes para o mesmo texto. Contudo, a dimensão histórica é importante por outro motivo: aparentemente, o poema é resultado direto das longas conversas de Tolkien com seu colega de Oxford, o norte-irlandês C.S. Lewis, acerca do verdadeiro propósito e valor da mitologia para o mundo real. Quando os dois escritores se conheceram no final dos anos 1920, Lewis era agnóstico, embora nutrisse imensa paixão pela mitologia nórdica. Com um gosto mitológico parecido, Tolkien decidiu se empenhar na conversão do amigo ao cristianismo, ${ }^{153}$ usando como argumento as verdades que todos os mitos, e principalmente o mito cristão, seriam capazes de revelar. A argumentação teológica de Tolkien antecipa de forma interessante alguns textos do catolicismo da era do Concílio Vaticano II, a partir de 1962: tal como os padres do Concílio, que viam "sinais do Verbo" divino nas verdades das religiões não-cristãs, Tolkien diz que os mitos nãocristãos guardam em si elementos do grande Mito que adentrou o Mundo Primário: o Evangelho.

\footnotetext{
${ }^{153}$ Para ser mais preciso, ao catolicismo romano. No entanto, apesar dos esforços do amigo, Lewis voltou ao anglicanismo, denominação cristã na qual foi educado, o que acabou se tornando um motivo de tensão entre os dois para o resto da vida.
} 
A história da conversa que finalmente culminou na conversão de Lewis está contada na biografia de Tolkien escrita por Humphrey Carpenter, mas não é exagero dizer que Mythopoeia é o retrato dessa conversa em forma poética. A citação em On fairy-stories se refere a esse mesmo contexto, embora o relato sobre uma "carta" seja apenas para efeito dramático: Tolkien nunca enviou o poema pelo correio para o amigo. O texto provavelmente foi escrito no começo dos anos 1930.

De acordo com o biógrafo, a frase dedicatória do poema (que compara os mitos a "mentiras bafejadas através da prata") foi dita originalmente pelo próprio Lewis. Da mesma forma, Philomythus (o que ama os mitos) é Tolkien, enquanto Misomythus (o que odeia os mitos) representa Lewis. Este é claramente um poema-programa, importante não só em si mesmo, mas principalmente pelo projeto literário que representa. A linguagem, em muitos momentos, é a do confronto e da resistência. Isso se explica não só pelo ceticismo de Misomythus mas também pelo retorno de uma das obsessões tolkienianas: o perigo que o uso indiscriminado da tecnologia representa para a própria alma da humanidade. Tolkien nunca foi um ludita: para todos os efeitos, sua sólida formação em filologia comparada o torna, na prática, um cientista. Mas ele teme os efeitos desumanizadores de uma visão de mundo que tente restringir a realidade apenas àquilo que é sensível e mensurável, ou que elimine a dimensão espiritual (como nos versos "Não seguirei seus símios progressivos/ eretos e sapientes" na penúltima estrofe do poema, uma aparente referência ao triunfo do darwinismo como única visão de mundo verdadeira).

Além dessa preocupação, é interessante perceber como as imagens-chave de toda a mitologia ou legendarium tolkieniano, presentes em $\mathbf{O}$ senhor dos anéis e $\mathbf{O}$ Silmarillion, afloram nesse texto. Pode-se mesmo afirmar que esse é um sinal da maturidade da visão de mundo mitológica de Tolkien nesse momento: seus temas ganham uma espécie de centro de gravidade único, que atrai e organiza mesmo os textos mais díspares. Assim, os versos "e viajar numa vaga demanda/que alguns ao fabuloso Oeste manda" remetem diretamente ao mito de Valinor, a Terra Abençoada no Oeste, que os personagens da Terra-média conhecem como um análogo do Paraíso Terrestre. ${ }^{154}$ Mais adiante, outro par de versos (Eu não me curvo à Coroa de Ferro, /nem meu cetrozinho dourado enterro) usam como símbolo de tudo o que o espírito tolkieniano

\footnotetext{
${ }^{154}$ Esse mito, é claro, tem raízes muito mais profundas que o legendarium tolkieniano. Reflete-se em narrativas medievais, como as Viagens de São Brandão e outros textos de influência celta, além de elementos semelhantes na própria mitologia greco-romana, como o Jardim das Hespérides.
} 
quer combater a Coroa de Ferro, elemento muito importante de O Silmarillion - essa diadema é a marca da soberania de Morgoth, o Inimigo do Mundo, a versão tolkieniana de Lúcifer e o primeiro a tentar escravizar homens, elfos e a própria Terra por meio da violência e da tecnologia.

Antes de apresentar o poema no original e minha tradução, faço alguns breves comentários. Em termos formais, o texto não é exatamente um conundrum, ao menos à primeira vista: pentâmetros iâmbicos com rimas em dísticos (A-A, B-B etc.), agrupados em estrofes de tamanho variável. É exatamente a forma poética conhecida em inglês como heroic couplet, praticamente obrigatória para a poesia "séria" produzida de meados do século XVII a meados do século XVIII. Pope utiliza os "dísticos heróicos" em sua tradução da Ilíada, por exemplo, e em seus poemas de matriz fílosófica, como An Essay on Man. Assim, apesar de seus protestos em contrário, Tolkien mostra notável familiaridade com a "grande tradição" da poesia inglesa depois do século XVI. A discussão filosófica e teológica que é o tema de Mythopoeia acaba se adequando com naturalidade a essa escolha formal.

O texto tem um sabor tradicional (que se tentou reproduzir em português), mas ao mesmo tempo utiliza habilmente alguns termos tirados, por exemplo, do discurso acadêmico ou da ciência moderna, para criar desconcerto e ironia. Em português, mantive o decassílabo rimado (por vezes abusando da elisão, como será possível notar). Aliás, o recurso métrico proporcionado pela elisão permitiu, se não manter de todo, conservar pelo menos vestígios reconhecíveis da repetição de termos-chave em vários momentos importantes do poema. Mesmo assim, a amarração anafórica da versão em português é mais tênue que a do original, indiscutivelmente, bem como a liberdade para utilizar adjetivação, recurso que Tolkien não costuma poupar. Como no texto anterior e nos demais textos, os comentários do tradutor vêm na forma de notas de rodapé. 


\section{MYTHOPOEIA}

To one who said that myths were lies and therefore worthless, even though 'breathed through silver'.

Philomythus to Misomythus

You look at trees and label them just so,

(for trees are 'trees', and growing is 'to grow');

you walk the earth and tread with solemn pace

one of the many minor globes of Space:

a star's a star, some matter in a ball

compelled to courses mathematical

amid the regimented, cold, inane,

where destined atoms are each moment slain.

At bidding of a Will, to which we bend

(and must), but only dimly apprehend,

great processes march on, as Time unrolls

from dark beginnings to uncertain goals;

and as on page o'er-written without clue,

with script and limning packed of various hue,

an endless multitude of forms appear,

some grim, some frail, some beautiful, some queer,

each alien, except as kin from one

remote Origo, gnat, man, stone, and sun.

God made the petreous rocks, the arboreal trees,

tellurian earth, and stellar stars, and these

homuncular men, who walk upon the ground

with nerves that tingle touched by light and sound. 


\section{MYTHOPOEIA}

A alguém que disse que mitos eram mentiras e, portanto, inúteis, mesmo se "bafejados através da prata".

Philomythus a Misomythus

Você vê árvores, e as chama assim:

“árv’res” são "árv’res” e crescem, enfim; ${ }^{155}$

palmilha a terra e com solene passo

pisa um dos globos menores do Espaço:

'Strelas são 'strelas, matéria em bola'

que em matemático trajeto rola,

regimentado, gélido, Vazio,

de átomos morrendo a sangue frio.

Por uma Vontade, à qual nos dobramos

mas que nós só de longe captamos,

grandes processos o Tempo completa

de início escuro a incerta meta;

e em página reescrita sem pista,

de letra e margem vária já revista,

eis multidão de formas infinitas,

negras, belas, frágeis ou esquisitas,

cada qual diversa, mas num só rol $^{157}$

de germe, inseto, homem, pedra e sol.

Deus fez pétreas rochas, arbóreas árvores,

terra térrea, estrelas estelares,

e os homens humanos, que andam no chão

e a quem luz e som causam comichão. ${ }^{158}$

\footnotetext{
${ }^{155} \mathrm{O}$ uso da elisão proporciona uma maneira de manter a repetição de "árvores", tão típica do presente poema.

${ }^{156}$ A elisão acaba sendo obrigatória aqui também. Nesse caso, vai contra os hábitos da poesia em português, mas não chega a ser desfiguradora, na minha opinião.
} 
The movements of the sea, the wind in boughs, green grass, the large slow oddity of cows, thunder and lightning, birds that wheel and cry, slime crawling up from mud to live and die, these each are duly registered and print the brain's contortions with a separate dint.

Yet trees are not 'trees', until so named and seen and never were so named, till those had been who speech's involuted breath unfurled, faint echo and dim picture of the world, but neither record nor a photograph, being divination, judgement, and a laugh response of those that felt astir within by deep monition movements that were kin to life and death of trees, of beasts, of stars: free captives undermining shadowy bars, digging the foreknown from experience and panning the vein of spirit out of sense. Great powers they slowly brought out of themselves and looking backward they beheld the elves that wrought on cunning forges in the mind, and light and dark on secret looms entwined.

He sees no stars who does not see them first of living silver made that sudden burst to flame like flowers beneath an ancient song, whose very echo after-music long

\footnotetext{
${ }^{157}$ Aqui, "um só rol" funciona como equivalente do "parentesco" fundamental entre a lista que vai de germe a homem.

${ }^{158}$ Mais uma vez, a imagem breve do "comichão" ou da coceira pretende invocar os nervos que se recolhem e se esticam sob o estímulo dos órgãos dos sentidos - uma das descrições ao mesmo tempo mais simples e tocantes (sem trocadilho) do poema.
} 
O remexer do mar, vento nos galhos, relva, vacas mugindo nos atalhos, ${ }^{159}$ trovão e raio, aves a cantar, limo escorrendo a viver e murchar, cada qual é registrado e impresso nas contorções do cérebro em recesso.

Mas “árv’res” só são "árv’res” nomeadas -

e só o foram quando captadas

por quem abriu o hálito da fala, eco do mundo numa escura sala, mas nem registro nem fotografia, sendo risada, juízo e profecia, resposta dos que então sentiram dentro profundo movimento cujo centro é o existir de planta, fera, estrela: cativos que grade serram sem vê-la, ${ }^{160}$ cavando o sabido da experiência abrindo o espírito sem consciência. Grande poder de si mesmos criaram, e atrás de si os elfos contemplaram que na forja sagaz d'alma andavam, luz e treva em teia oculta bordavam.

Não vê estrelas quem não as vê primeiro qual prata viva explodindo em chuveiro chama florida sob canção antiga cujo eco mesmo de longa cantiga ${ }^{161}$

\footnotetext{
${ }^{159}$ Mais uma vez, parte-se do abstrato para o concreto - a imagem de uma vaca mugindo é o ícone perfeito da "grande estranheza lenta" dos animais que Tolkien destaca.

${ }^{160}$ A idéia de que os cativos são livres e que as grades são "de sombra" teve de ser condensada na imagem dos cativos que não vêem a grade, mas ainda assim a serram. $O$ resultado não me parece muito diferente de um kenning: na imagem condensada, quase uma metonímia do que está acontecendo, é possível entrever o significado maior da cena.

${ }^{161}$ Embora haja certa insistência na série "canção/cantiga", a solução me parece resolver não apenas a rima, mas a seqüência song/music do original.
} 
has since pursued. There is no firmament, only a void, unless a jewelled tent myth-woven and elf-patterned; and no earth, unless the mother's womb whence all have birth.

The heart of Man is not compound of lies, but draws some wisdom from the only Wise, and still recalls him. Though now long estranged, Man is not wholly lost nor wholly changed.

Dis-graced he may be, yet is not dethroned, and keeps the rags of lordship once he owned, his world-dominion by creative act: not his to worship the great Artefact, Man, Sub-creator, the refracted light through whom is splintered from a single White to many hues, and endlessly combined in living shapes that move from mind to mind. Though all the crannies of the world we filled with Elves and Goblins, though we dared to build Gods and their houses out of dark and light, and sowed the seed of dragons, 'twas our right (used or misused). The right has not decayed. We make still by the law in which we're made.

Yes! 'wish-fulfilment dreams' we spin to cheat our timid hearts and ugly Fact defeat!

Whence came the wish, and whence the power to dream, 
o perseguiu. Não há um firmamento, só vazio, se não tenda, paramento por elfos desenhado; não há terra, se não ventre de mãe que a vida encerra.

Mentiras não compõem o peito humano, que do único Sábio tira o seu plano e o recorda. Inda que alienado, algo não se perdeu nem foi mudado. ${ }^{162}$ Des-graçado está, mas não destronado, trapos da nobreza em que foi trajado, domínio do mundo por criação:

O deus Artefato não é seu quinhão, homem, sub-criador, luz refratada em quem a cor branca é despedaçada para muitos tons, e recombinada, forma viva mente a mente passada.

Se todas as cavas do mundo enchemos com elfos e duendes, se fizemos deuses com casas de treva e de luz, se plantamos dragões, ${ }^{163}$ a nós conduz um direito. E não foi revogado.

Criamos tal como fomos criados. ${ }^{164}$

Sim! Sonhos tecemos para enganar os corações e o Fato derrotar! ${ }^{165}$

De onde o desejo e o poder pra sonhar,

\footnotetext{
162 "Algo" aqui substitui ao original is not wholly lost/is not wholly changed.

163 Referência sutil à mitologia grega, que Tolkien parece ter apreciado tanto quanto o idioma helênico "as sementes de dragão" são os dentes de dragão semeados pelo herói Cadmo, o fundador da cidadeEstado de Tebas.

${ }^{164}$ Esse é o centro de gravidade filosófico do poema, assim como é o grande ápice de On-fairy stories. A humanidade tem a sub-criação como direito inalienável porque ela é uma conseqüência de sua natureza como criatura de Deus. Os filhos de um Criador têm como seu mais poderoso instinto o próprio ato de criar, segundo Tolkien.

${ }^{165}$ Por razões métricas, foi simplesmente impossível fazer com que o Fato fosse classificado como "o feito Fato", tal como acontece no poema original.
} 
or some things fair and others ugly deem?

All wishes are not idle, nor in vain

fulfilment we devise -- for pain is pain,

not for itself to be desired, but ill;

or else to strive or to subdue the will

alike were graceless; and of Evil this

alone is deadly certain: Evil is.

Blessed are the timid hearts that evil hate

that quail in its shadow, and yet shut the gate;

that seek no parley, and in guarded room, though small and bate, upon a clumsy loom

weave tissues gilded by the far-off day

hoped and believed in under Shadow's sway.

Blessed are the men of Noah's race that build their little arks, though frail and poorly filled, and steer through winds contrary towards a wraith, a rumour of a harbour guessed by faith.

Blessed are the legend-makers with their rhyme of things not found within recorded time.

It is not they that have forgot the Night, or bid us flee to organized delight, in lotus-isles of economic bliss forswearing souls to gain a Circe-kiss (and counterfeit at that, machine-produced, bogus seduction of the twice-seduced). 
e as coisas belas ou feias julgar?

Querer não é inútil, nem calor

procuramos em vão - pois dor é dor,

não de ser desejada, mas perversa;

ou ceder a uma vontade adversa

ou resistir seria igual. E o Mal,

desse apenas isto é certo: É o Mal. ${ }^{166}$

Bendito o tímido que o mal odeia,

treme na sombra, e o portão cerceia;

que não quer trégua, e em seu solar,

mesmo pequeno, num velho tear

tece pano dourado à luz do dia

sonhado por quem na Sombra porfia.

Benditos os que de Noé descendem, ${ }^{167}$

co’ arca frágil e vazia o mar fendem,

sob ventos contrários buscando sé,

rumor de um porto indicado por fé.

Benditos os que em rima fazem lenda

ao tempo não-gravado dando emenda.

Não foram eles que a Noite esqueceram,

ou deleite organizado teceram,

ilhas de lótus, um céu financeiro,

perdendo a alma em beijo feiticeiro ${ }^{168}$

(e falso, aliás, pré-fabricado,

falaz sedução do já-deturpado).

\footnotetext{
${ }^{166}$ Alguém poderia argumentar que a ordem de palavras nesse caso é significativa - "o Mal é", ou seja "o Mal existe, tem existência própria e definida", mas creio que seria exagerado atribuir a Tolkien, católico praticante e fervoroso com boa instrução teológica, uma crença maniqueísta dessa natureza.

${ }^{167}$ Outro caso em que um verbo faz as vezes da expressão, ao estilo dos kennings, Noah's race.

${ }^{168}$ A referência ao mundo homérico, já presente em "ilhas de lótus", fica um pouco obscurecida com a ausência do nome "Circe" nesse verso traduzido, mas continua a ser pelo menos sugerida pelo adjetivo "feiticeiro".
} 
Such isles they saw afar, and ones more fair, and those that hear them yet may yet beware. They have seen Death and ultimate defeat, and yet they would not in despair retreat, but oft to victory have turned the lyre and kindled hearts with legendary fire, illuminating Now and dark Hath-been with light of suns as yet by no man seen.

I would that I might with the minstrels sing and stir the unseen with a throbbing string. I would be with the mariners of the deep that cut their slender planks on mountains steep and voyage upon a vague and wandering quest, for some have passed beyond the fabled West. I would with the beleaguered fools be told, that keep an inner fastness where their gold, impure and scanty, yet they loyally bring to mint in image blurred of distant king, or in fantastic banners weave the sheen heraldic emblems of a lord unseen.

I will not walk with your progressive apes, erect and sapient. Before them gapes the dark abyss to which their progress tends if by God's mercy progress ever ends, and does not ceaselessly revolve the same unfruitful course with changing of a name. I will not treat your dusty path and flat, 
Tais ilhas vêem ao longe, e outras mais belas,

e os que os ouvem podem girar as velas.

Viram a Morte e a derrota final

sem em desespero fugir do mal,

mas à vitória viraram a lira,

seus corações qual legendária pira,

iluminando o Agora e o Que Tem Sido

com brilho de sóis por ninguém vivido.

Quisera com os menestréis cantar

com minha corda o não-visto tocar.

Quisera navegar com os marinheiros

que cortam tábua em montes altaneiros ${ }^{169}$

e viajar numa vaga demanda

que alguns ao fabuloso Oeste manda.

Quisera entre os tolos ser sitiado,

que em remoto forte, de ouro guardado,

impuro e escasso, recriam leais

imagem tênue de pendões reais,

ou em bandeira tecem o brasão

fulgurante de não-visto varão.

Não seguirei seus símios progressivos,

eretos e sapientes. ${ }^{170}$ Caem vivos

nesse abismo ao qual seu progresso tende -

se por Deus o progresso um dia se emende

e não sem cessar revolva o batido

curso sem fruto com outro apelido.

Não trilharei sua rota sem vacilo,

\footnotetext{
${ }^{169}$ A imagem é a do marinheiro que primeiro busca a madeira com a qual fará seu navio numa montanha. Não é impossível que, em mais uma referência clássica, Tolkien esteja pensando no santuário de Dodona, na região montanhosa do Épiro (noroeste da Grécia), de onde veio a madeira da quilha para o navio dos Argonautas.

${ }^{170}$ Usar a tradução literal de erect e sapient me parece essencial - afinal, tratam-se também de traduções de erectus e sapiens, nomes lineanos de duas das espécies humanas classificadas pelos cientistas modernos.
} 
denoting this and that by this and that, your world immutable wherein no part the little maker has with maker's art. I bow not yet before the Iron Crown, nor cast my own small golden sceptre down.

In Paradise perchance the eye may stray from gazing upon everlasting Day to see the day illumined, and renew from mirrored truth the likeness of the True. Then looking on the Blessed Land 'twill see that all is as it is, and yet made free:

Salvation changes not, nor yet destroys, garden nor gardener, children nor their toys. Evil it will not see, for evil lies not in God's picture but in crooked eyes, not in the source but in malicious choice, and not in sound but in the tuneless voice. In Paradise they look no more awry; and though they make anew, they make no lie. Be sure they still will make, not being dead, and poets shall have flames upon their head, and harps whereon their faultless fingers fall: there each shall choose for ever from the All. 
que a isto e aquilo chama isto e aquilo,

mundo imutável onde não tem parte

criadorzinho ou de criar a arte. ${ }^{171}$

Eu não me curvo à Coroa de Ferro,

nem meu cetrozinho dourado enterro.

No Paraíso pode o olho vagar

do Dia imorredouro contemplar

a ver o que ele ilumina, e nova

Verdade ter com essa vera prova. ${ }^{172}$

Olhando a Terra Bendita verá

que tudo é como é, e livre será:

A Salvação não muda nem destrói,

jardim, criança ou brinquedo corrói.

Mal não verá, pois esse mal está

não no que Deus fez, mas no erro do olhar, ${ }^{173}$

não na fonte, mas em escolha errada,

e não no som, mas na voz quebrantada.

No Paraíso a confusão não jaz;

criam, mas mentira não criam mais.

Criarão, não estando mortos, é certo,

poetas com halo de chamas perto,

e harpas que sem falta tocarão:

do Todo cada um terá quinhão.

\footnotetext{
${ }^{171}$ A inversão um tanto barroca fica ligeiramente fora de lugar num poema que é bastante coloquial na maioria dos trechos, mas é a única maneira de manter a repetição de make/maker.

${ }_{172}$ Mais uma vez, a sintaxe um tanto rebuscada é o que permite a repetição crucial de truth/true.

${ }^{173}$ Trata-se de uma rima realmente "sonora" (dada a pronúncia dominante do português brasileiro), e não de "olho", evidentemente.
} 


\section{Leaf by Niggle}

A história de Leaf by Niggle se entrelaça não só com os demais textos de Tree and Leaf mas também com a da obra-prima tolkieniana, $\mathbf{O}$ senhor dos anéis. Escrito no final dos anos 1930, o conto é um dos trabalhos mais autobiográficos de Tolkien, refletindo a ansiedade que acompanhava a criação da Saga do Anel e o que o autor via então como sua incapacidade de concluir o universo ficcional com o qual sonhava e no qual trabalhava desde a juventude. Quando a história tomou forma, conta Tolkien no prefácio original de Tree and Leaf, os hobbits Frodo, Sam, Merry e Pippin (que então nem esses nomes tinham ainda) tinham apenas começado sua jornada para Valfenda. $\mathrm{O}$ escritor simplesmente não sabia como a trama continuaria a partir dali, "and I had begun to despair of surviving to find out".

É por isso que Niggle, o pintor que, como o nome deixa entrever, perde-se o tempo todo em detalhes e incômodos menores sem conseguir concluir a obra de sua vida, é provavelmente uma das únicas e melhores alegorias do próprio Tolkien em seu trabalho - fato mais importante do que a descrição deixa entrever, porque o autor normalmente se dizia avesso a alegorias de qualquer natureza. ${ }^{174}$ Tom Shippey vê na história de Niggle quase uma tentativa de Tolkien de se justificar perante seus pares por seu desempenho acadêmico (medido basicamente por publicações de impacto, então como hoje) abaixo do esperado. Ele chega mesmo a traçar uma relação entre elementos como o canteiro onde antigamente Niggle plantava batatas (supostamente o antigo e "produtivo" trabalho de pesquisa acadêmica de Tolkien), o fato de esse lugar agora estar ocupado pela imensa e interminável pintura da Árvore (a obra ficcional de Tolkien, que para todos os efeitos realmente nunca foi concluída) e a queda na produtividade acadêmica do escritor. Com efeito, quando $\mathbf{O}$ senhor dos anéis finalmente foi publicado, não poucos colegas de Tolkien em Oxford e outros lugares parecem ter resmungado coisas do tipo: “Ah, então era isso que ele andou fazendo esses anos todos". Além do mais, o escritor refere-se a si mesmo como o exemplo mais acabado de niggler em suas cartas, o que não deixa de ser verdade. O que mais assombra o leitor familiarizado com a totalidade da obra tolkieniana talvez nem seja sua vastidão - e ela é realmente grande, suficiente para encher cerca de 20 volumes com mais de 400 páginas cada um -, mas o fato de que $90 \%$ desse material não viu a luz do dia durante a vida do

\footnotetext{
${ }^{174}$ No prefácio da segunda edição de $\mathbf{O}$ senhor dos anéis, Tolkien alega ter um "desgosto cordial" por todas as formas de alegoria.
} 
autor por excesso de perfeccionismo, por um hábito quase obsessivo de revisar e reescrever detalhes que qualquer outra pessoa julgaria irrelevantes. Nesse sentido talvez é que Tolkien defina o texto como "part apologia, part confession" numa carta a seus editores da Allen \& Unwin (CARPENTER, 1995, p. 113).

A essa altura talvez não seja mais necessário ressaltar o fato, mas o aspecto inegavelmente religioso da alegoria em Leaf by Niggle a conecta de forma quase inconsútil com On fairy-stories e Mythopoeia. Afinal, não é preciso muito para interpretar a Oficina e o Hospital onde Niggle passa por seu duro reaprendizado como uma espécie de Purgatório. Mais que isso: no fim das contas, o pintor descobre que sua obra foi aceita como parte da Criação divina, exatamente como Tolkien sonha que as estórias de fadas e os mitos vão ser aceitos (e ampliados e vivificados) por Deus quando chegar a Grande Eucatástrofe da raça humana. ${ }^{175}$ Ironicamente, no "mundo real" o destino de Niggle e de seu país de origem é a barbárie e o esquecimento, no qual até o fragmento de um dos cantos da Árvore pintada será queimado junto com o museu que o abriga. Não é impossível que os momentos sombrios imediatamente anteriores ao início da Segunda Guerra Mundial tenham sugerido a Tolkien essa imagem de aniquilação completa da fantasia humana, bem como o ambiente lúgubre e, por falta de uma palavra melhor, quase kafkiano que espreita os personagens do conto.

O prefácio original da coletânea explicita outra inspiração autobiográfica para o conto e sua imagem central: a Árvore que é ao mesmo tempo a pintura onde Niggle deposita toda a sua capacidade criativa e o símbolo dessa capacidade como uma coisa quase viva. Tolkien diz que a Árvore é uma homenagem póstuma a um choupo que acabou sendo podado de forma brutal perto de sua casa, sem nenhum motivo aparente:

"It was suddenly lopped and mutilated by its owner, I do not know why. It is cut down now, a less barbarous punishment for any crimes it may have been accused of, such as being large and alive. I do not think it had any friends, or any mourners except myself and a pair of owls". 
Talvez também não seja por acaso que o conto utilize a mesma linguagem despojada e coloquial dos primeiros capítulos de O senhor dos anéis. De quando em quando, porém, ela resvala para o poético e o simbólico, o que tornou a tradução um trabalho mais difícil do que o observador ocasional poderia imaginar. Mas, de forma tipicamente filológica, Tolkien investe sua capacidade "mitopoética" ao criar os nomes dos personagens, o que levou-me a optar por traduzi-los para o português, como ficará claro abaixo. É nos nomes que os traços alegóricos do texto ficam mais patentes e, no texto traduzido abaixo, discuto cada caso e as minhas opções de tradução para eles.

${ }^{175}$ Quando Tolkien morreu em 1973, um serviço religioso celebrado em sua memória na Califórnia por fãs americanos utilizou como "leitura" justamente o momento eucatastrófico de Leaf by Niggle, quando o personagem-título recebe o "dom” de ver sua Árvore concluída e viva. 


\section{LEAF BY NIGGLE}

There was once a little man called Niggle, who had a long journey to make. He did not want to go, indeed the whole idea was distasteful to him; but he could not get out of it. He knew he would have to start some time, bur he did not hurry with his preparations.

Niggle was a painter. Not a very successful one, partly because he had many other things to do. Most of these things he thought were a nuisance; but he did them fairly well, when he could not get out of them: which (in his opinion) was far too often. The laws in his country were rather strict. There were other hindrances, too. For one thing, he was sometimes just idle, and did nothing at all. For another, he was kindhearted, in a way. You know the sort of kind heart: it made him uncomfortable more often than it made him do anything; and even when he did anything, it did not prevent him from grumbling, losing his temper, and swearing (mostly to himself). All the same, it did land him in a good many odd jobs for his neighbour, Mr. Parish, a man with a lame leg. Occasionally he even helped other people from further off, if they came and asked him to. Also, now and again, he remembered his journey, and began to pack a few things in an ineffectual way: at such times he did not paint very much.

He had a number of pictures on hand; most of them were too large and ambitious for his skill. He was the sort of painter who can paint leaves better than trees.

He used to spend a long time on a single leaf, trying to catch its shape, and its sheen, and the glistening of dewdrops on its edges. Yet he wanted to paint a whole tree, with all of its leaves in the same style, and all of them different. 


\section{Folha de Cisco $^{176}$}

Era uma vez um homenzinho chamado Cisco, que tinha uma longa viagem a fazer. Não queria ir, na verdade a idéia toda era desagradável para ele; mas não conseguia se livrar. Sabia que teria de começar algum dia, mas não se apressava com seus preparativos.

Cisco era pintor. Não muito bem-sucedido, em parte porque tinha muitas outras coisas a fazer. A maioria dessas coisas ele achava um incômodo; mas as fazia razoavelmente bem, quando não conseguia se livrar delas: o que (na sua opinião) era freqüente até demais. As leis no seu país eram bem severas. Havia outros obstáculos também. Por um lado, ele às vezes era apenas ocioso, e não fazia nada mesmo. Por outro, tinha coração bom, de certa maneira. Sabe ${ }^{177}$ o tipo de coração bom: levava-o a se sentir desconfortável mais do que o levava a fazer alguma coisa; e, mesmo quando fazia alguma coisa, não o impedia de resmungar, perder a paciência e xingar (mais para si mesmo). Mesmo assim, aquilo lhe empurrava um bom número de serviços de seu vizinho, Sr. Paróquia ${ }^{178}$, um homem com uma perna manca. Ocasionalmente ele ajudava até outras pessoas de mais longe, se viessem e lhe pedissem. Além disso, de vez em quando, ele se lembrava de sua viagem, e começava a empacotar algumas coisas de um jeito ineficiente: nessas horas, não pintava muito.

Estava trabalhando em algumas pinturas; a maioria delas era grande e ambiciosa demais para o seu talento. Era o tipo de pintor que consegue pintar folhas melhor do que árvores. Costumava gastar muito tempo numa só folha, tentando capturar sua forma, e seu brilho, e a radiância das gotas de orvalho nas suas bordas. Contudo, queria pintar uma árvore inteira, com todas as suas folhas no mesmo estilo, e todas elas diferentes.

\footnotetext{
${ }^{176}$ Traduzir Cisco foi um verdadeiro pesadelo, mas me pareceu essencial. É um procedimento que Tolkien defendeu também para os nomes cuidadosamente "montados" de $\mathbf{O}$ senhor dos anéis. O verbo to niggle, provavelmente de origem escandinava, significa tanto "enrolar", trabalhar sem método e de forma ineficaz, quanto incomodar de forma leve e persistente. Essa última característica me levou para "Cisco", além das conexões com o verbo "ciscar", que se conecta com o primeiro sentido de Cisco - embora normalmente o empreguemos, em português, para nos referir a jogadores de futebol que correm muito, mas não produzem nada em campo.

${ }^{177} \mathrm{O}$ tom coloquial de you know e desse "sabe" em português se encaixam bastante bem, na minha opinião.

${ }^{178} \mathrm{O}$ fato de optar, no fim das contas, pela tradução literal de Parish não significa que o sobrenome também não tenha dado trabalho. Minha opção original era Villa, tanto por manter o trocadilho que é crucial no desfecho do conto quanto por soar mais natural como um sobrenome em português. A questão, no entanto, é que tanto parish quanto "paróquia" derivam do grego paroikos - "o que mora ao lado", ou seja, "o vizinho". Parece altamente improvável que essa piada pronta filológica tenha sido fruto do acaso. Afinal, que nome melhor para um vizinho que o de "vizinho", especialmente num conto em que ninguém
} 
There was one picture in particular which bothered him. It had begun with a leaf caught in the wind, and it became a tree; and the tree grew, sending out innumerable branches, and thrusting out the most fantastic roots. Strange birds came and settled on the twigs and had to be attended to. Then all round the Tree, and behind it, through the gaps in the leaves and boughs, a country began to open out; and there were glimpses of a forest marching over the land, and of mountains tipped with snow. Niggle lost interest in his other pictures; or else he took them and tacked them on to the edges of his great picture. Soon the canvas became so large that he had to get a ladder; and he ran up and down it, putting in a touch here, and rubbing out a patch there. When people came to call, he seemed polite enough, though he fiddled a little with the pencils on his desk. He listened to what they said, but underneath he was thinking all the time about his big canvas, in the tall shed that had been built for it out in his garden (on a plot where once he had grown potatoes).

He could not get rid of his kind heart. 'I wish I was more strong-minded' he some times said to himself, meaning that he wished other people's troubles did not make him feel uncomfortable. But for a long time he was not seriously perturbed. 'At any rate, I shall get this one picture done, my real picture, before I have to go on that wretched journey,' he used to say. Yet he was beginning to see that he could not put off his start indefinitely. The picture would have to stop just growing and get finished.

One day, Niggle stood a little way off from his picture and considered it with unusual attention and detachment. He could not make up his mind what he thought about it, and wished he had some friend who would tell him what to think. Actually it seemed to him wholly unsatisfactory, and yet very lovely, the only really beautiful picture in the world. What he would have liked at that moment would have been to see himself walk in, and slap him on the back, and say (with obvious sincerity): 'Absolutely magnificent! I see exactly what you are getting at. Do get on with it, and don't bother about anything else! We will arrange for a public pension, so that you need not.'

parece ter um nome próprio de verdade e praticamente todos os nomes são títulos ou essências? Creio que isso justifica a opção adotada aqui. 
Havia uma pintura em particular que o incomodava. Tinha começado com uma folha levada pelo vento, e se tornou uma árvore; e a árvore cresceu, esticando galhos inumeráveis, e lançando as mais fantásticas raízes. Pássaros estranhos vieram e se instalaram nos ramos e tiveram de receber atenção. Então, à toda volta da árvore, e atrás dela, através das aberturas entre as folhas e frondes, um país começou a se mostrar; e havia vislumbres de uma floresta marchando sobre a terra, ${ }^{179}$ e de montanhas encimadas de neve. Cisco perdeu o interesse em suas outras pinturas; ou então as tomou e pregou às bordas de sua grande pintura. Logo a tela se tornou tão grande que ele tinha de usar uma escada; e ia de alto a baixo dela, dando um retoque aqui e apagando um pedaço ali. Quando as pessoas vinham chamá-lo, parecia educado o suficiente, embora dedilhasse um pouco os lápis de sua escrivaninha. Escutava o que diziam, mas no fundo estava pensando o tempo todo em sua grande tela, no armazém alto que tinha construído para ela em seu jardim (num canteiro onde antes ele plantara batatas).

Não conseguia se livrar de seu coração. "Gostaria de ter gênio mais forte!", ${ }^{180}$ dizia às vezes para si mesmo, querendo dizer que gostaria que os problemas de outras pessoas não o fizessem se sentir desconfortável. Mas por muito tempo ele não foi seriamente perturbado. "De qualquer jeito, vou terminar essa pintura, minha verdadeira pintura, antes que eu tenha de fazer aquela viagem desgraçada", costumava dizer. Contudo, estava começando a perceber que não conseguiria adiar sua partida indefinidamente. A pintura teria de parar de apenas crescer e ser terminada.

Um dia, Cisco ficou de pé a uma pequena distância de sua pintura e a considerou com atenção e distanciamento incomuns. Não conseguia se decidir sobre o que achava dela, e queria ter algum amigo que pudesse lhe dizer o que pensar. Na verdade, ela the parecia completamente insatisfatória, e contudo muito adorável, a única pintura realmente bela no mundo. Do que ele gostaria naquele momento seria ver a si mesmo entrar, dar-se um tapa nas costas e dizer (com sinceridade óbvia): “Absolutamente magnífico! Vejo exatamente aonde você está chegando. Continue mesmo com isso e não se incomode com mais nada! Vamos arranjar uma pensão pública, para que você não precise".

\footnotetext{
${ }^{179}$ Pode haver uma ambigüidade em marching over (uma floresta nas fronteiras da terra?), mas Tom Shippey interpreta a expressão como uma referência aos Ents, os gigantes "arborescos" de O senhor dos anéis que realmente fazem uma floresta "marchar sobre a terra" na saga. Na falta de uma referência mais definitiva, a opção me pareceu no mínimo interessante.
} 
However, there was no public pension. And one thing he could see: it would need some concentration, some work, hard uninterrupted work, to finish the picture, even at its present size. He rolled up his sleeves, and began to concentrate. He tried for several days not to bother about other things. But there came a tremendous crop of interruptions. Things went wrong in his house; he had to go and serve on a jury in the town; a distant friend fell ill; Mr. Parish was laid up with lumbago; and visitors kept on coming. It was springtime, and they wanted a free tea in the country: Niggle lived in a pleasant little house, miles away from the town. He cursed them in his heart, but he could not deny that he had invited them himself, away back in the winter, when he had not thought it an 'interruption' to visit the shops and have tea with acquaintances in the town. He tried to harden his heart; but it was not a success. There were many things that he had not the face to say no to, whether he thought them duties or not; and there were some things he was compelled to do, whatever he thought. Some of his visitors hinted that his garden was rather neglected, and that he might get a visit from an Inspector. Very few of them knew about his picture, of course; but if they had known, it would not have made much difference. I doubt if they would have thought that it mattered much. I dare say it was not really a very good picture, though it may have had some good passages. The Tree, at any rate, was curious. Quite unique in its way. So was Niggle; though he was also a very ordinary and rather silly little man.

At length Niggle's time became really precious. His acquaintances in the distant town began to remember that the little man had got to make a troublesome journey, and some began to calculate how long at the latest he could put off starting. They wondered who would take his house, and if the garden would be better kept.

The autumn carne, very wet and windy. The little painter was in his shed. He was up on the ladder, trying to catch the gleam of the westering sun on the peak of a snow-mountain, which he had glimpsed just to the left of the leafy tip of one of the Tree's branches. He knew that he would have to be leaving soon: perhaps early next year. He could only just get the picture finished, and only so so, at that: there were some corners where he would not have time now to do more than hint at what he wanted.

\footnotetext{
${ }^{180}$ Se a correspondência com strong-minded não é exatamente perfeita, permanece pelo menos o adjetivo "forte", que parece relevante nesse contexto.
} 
Entretanto, não havia pensão pública. E uma coisa ele conseguia perceber: seria preciso alguma concentração, algum trabalho, trabalho duro ininterrupto, para terminar a pintura, mesmo no seu tamanho presente. Ele arregaçou as mangas e começou a se concentrar. Tentou por vários dias não se incomodar com outras coisas. Mas veio uma colheita tremenda de interrupções. Coisas quebraram na sua casa; ele teve de ir compor um júri na cidade; um amigo distante caiu doente; o Sr. Paróquia estava de cama com lumbago; e os visitantes continuavam a vir. Era primavera, e eles queriam chá de graça no campo: Cisco vivia numa casinha agradável, a milhas da cidade. Ele os amaldiçoou em seu coração, mas não podia negar que ele próprio os tinha convidado, no inverno, quando não considerava uma "interrupção" visitar as lojas e tomar chá com conhecidos na cidade. Tentou endurecer seu coração; mas não foi um sucesso. Havia muitas coisas para as quais ele não tinha cara ${ }^{181}$ de dizer não, considerando-as deveres ou não; e havia algumas coisas que era forçado a fazer, seja lá o que pensasse. Alguns de seus visitantes insinuaram que seu jardim estava bastante negligenciado, e que ele poderia receber a visita de um Inspetor. Muito poucos deles sabiam de sua pintura, é claro; mas, se soubessem, não teria feito muita diferença. Duvido que teriam achado que importasse muito. Ouso dizer que não era realmente uma pintura muito boa, embora pudesse ter algumas boas passagens. A Árvore, de qualquer jeito, era curiosa. Bem única a seu modo. Assim era Cisco; embora ele também fosse um homenzinho muito comum e bastante bobo.

No fim, o tempo de Cisco se tornou realmente precioso. Seus conhecidos na cidade distante começaram a lembrar que o homenzinho tinha de fazer uma viagem complicada, e alguns começaram a calcular por quanto tempo no máximo ele conseguiria adiar a partida. Imaginaram quem tomaria sua casa, e se o jardim seria melhor cuidado.

O outono veio, muito úmido e ventoso. O pintorzinho estava em seu armazém. Estava no alto da escada, tentando capturar o brilho do sol poente no pico de uma montanha nevada, que ele tinha vislumbrado exatamente à esquerda da ponta folhosa de um dos galhos da Árvore. Sabia que teria de partir logo: talvez no começo do ano seguinte. Era o tempo exato de ele terminar a pintura, e só mais ou menos, se tanto: havia alguns cantos dela nos quais agora não teria tempo de fazer mais do que esboçar o que queria.

\footnotetext{
${ }^{181}$ A expressão talvez seja um pouco coloquial demais, mas é um equivalente claro em português para to have the face to em inglês.
} 
There was a knock on the door. 'Come in!' he said sharply, and climbed down the ladder. He stood on the floor twiddling his brush. It was his neighbour, Parish: his only real neighbour, all other folk lived a long way off. Still, he did not like the man very much: partly because he was so often in trouble and in need of help; and also because he did not care about painting, but was very critical about gardening. When Parish looked at Niggle's garden (which was often) he saw mostly weeds; and when he looked at Niggle's pictures (which was seldom) he saw only green and grey patches and black lines, which seemed to him nonsensical. He did not mind mentioning the weeds (a neighbourly duty), but he refrained from giving any opinion of the pictures. He thought this was very kind, and he did not realize that, even if it was kind, it was not kind enough. Help with the weeds (and perhaps praise for the pictures) would have been better.

'Well, Parish, what is it?' said Niggle.

'I oughtn't to interrupt you, I know,' said Parish (without a glance at the picture). 'You are very busy, I'm sure.'

Niggle had meant to say something like that himself, but he had missed his chance. All he said was: 'Yes.'

'But I have no one else to turn to,' said Parish.

'Quite so,' said Niggle with a sigh: one of those sighs that are a private comment, but which are not made quite inaudible. 'What can I do for you?'

'My wife has been ill for some days, and I am getting worried,' said Parish. 'And the wind has blown half the tiles off my roof, and water is pouring into the bedroom. I think I ought to get the doctor. And the builders, too, only they take so long to come. I was wondering if you had any wood and canvas you could spare, just to patch me up and see me through for a day or two.' Now he did look at the picture.

'Dear, dear!' said Niggle. 'You are unlucky. I hope it is no more than a cold that your wife has got. I'll come round presently, and help you move the patient downstairs.'

'Thank you very much,' said Parish, rather coolly. 'But it is not a cold, it is a fever. I should not have bothered you for a cold. And my wife is in bed downstairs already. I can't get up and down with trays, not with my leg. But I see you are busy. Sorry to have troubled you. I had rather 
Veio uma batida na porta. "Entre!", disse bruscamente, e desceu a escada. Ficou de pé no chão girando seu pincel. Era seu vizinho, Paróquia: seu único vizinho verdadeiro, todas as outras pessoas viviam bem longe. Ainda assim, não gostava muito do homem: em parte porque ele estava com tanta freqüência em apuros e precisando de ajuda; e também porque não ligava para pintura, mas era muito crítico em relação a jardinagem. Quando Paróquia olhava para o jardim de Cisco (o que era freqüente), via principalmente ervas daninhas; e quando olhava para as pinturas de Cisco (o que era raro), via somente manchas verdes e cinzas e linhas pretas, que lhe pareciam sem sentido. Não se importava em mencionar as ervas (um dever de vizinho), mas evitava dar qualquer opinião sobre as pinturas. Achava que isso era muito bondoso, e não percebia que, mesmo se fosse bondoso, não era bondoso o suficiente. Ajuda com as ervas (e talvez elogios para as pinturas) teria sido melhor.

“Bem, Paróquia, o que é?”, disse Cisco.

"Não devia interrompê-lo, eu sei”, disse Paróquia (sem um olhar para a pintura). "Você está muito ocupado, com certeza."

Cisco queria ter dito ele mesmo algo do tipo, mas tinha perdido a oportunidade. Tudo o que disse foi: "Sim".

"Mas não tenho mais ninguém a quem recorrer", disse Paróquia.

"Pois é", disse Cisco com um suspiro: um daqueles suspiros que são um comentário particular, mas que não são exatamente inaudíveis. "O que posso fazer por você?"

"Minha mulher anda doente faz alguns dias, e estou ficando preocupado", disse Paróquia. "E o vento arrancou metade das telhas do meu telhado, e a água está caindo dentro do quarto. Acho que devo chamar o médico. E os pedreiros também, só que eles levam tanto tempo para vir. Estava pensando se você não teria alguma madeira e tela que pudesse emprestar, só para me tapar o buraco e me ajudar a agüentar mais um dia ou dois.” Dessa vez ele olhou para a pintura.

"Nossa, nossa!", disse Cisco. "Você é azarado. Espero que sua mulher não tenha mais que um resfriado. Vou até lá agora e o ajudo a trazer a paciente para o andar de baixo."

"Muito obrigado", disse Paróquia, bastante frio. "Mas não é um resfriado, é uma febre. Eu não teria incomodado você por causa de um resfriado. E minha mulher já está de cama no andar de baixo. Não consigo ficar subindo e descendo com bandejas, não com a minha perna. Mas vejo que está ocupado. Desculpe tê-lo incomodado. Eu bem 
hoped you might have been able to spare the time to go for the doctor, seeing how I'm placed; and the builder too, if you really have no canvas you can spare.'

'Of course,' said Niggle; though other words were in his heart, which at the moment was merely soft without feeling at all kind. 'I could go. I'll go, if you are really worried.'

'I am worried, very worried. I wish I was not lame,' said Parish.

So Niggle went. You see, it was awkward. Paris h was his neighbour, and everyone else a long way off. Niggle had a bicycle, and Parish had not, and could not ride one. Parish had a lame leg, a genuine lame leg which gave him a good deal of pain: that had to be remembered, as well as his sour expression and whining voice. Of course, Niggle had a picture and barely time to finish it. But it seemed that this was a thing that Parish had to reckon with and not Niggle. Parish, however, did not reckon with pictures; and Niggle could not alter that. 'Curse it!' he said to himself, as he got out his bicycle.

It was wet and windy, and daylight was waning. 'No more work for me today!' thought Niggle, and all the time that he was riding, he was either swearing to himself, or imagining the strokes of his brush on the mountain, and on the spray of leaves beside it, that he had first imagined in the spring. His fingers twitched on the handlebars. Now he was out of the shed, he saw exactly the way in which to treat that shining spray which framed the distant vision of the mountain. But he had a sinking feeling in his heart, a sort of fear that he would never now get a chance to try it out.

Niggle found the doctor, and he left a note at the builder's. The office was shut, and the builder had gone home to his fireside. Niggle got soaked to the skin, and caught a chill himself. The doctor did not set out as promptly as Niggle had done. He arrived next day, which was quite convenient for him, as by that time there were two patients to deal with, in neighbouring houses. Niggle was in bed, with a high temperature, and marvellous patterns of leaves and involved branches forming in his head and on the ceiling. It did not comfort him to learn that Mrs. Parish had only had a cold, and was getting up. He turned his face to the wall and buried himself in leaves.

He remained in bed some time. The wind went on blowing. It took away a good many more of Parish's tiles, and some of Niggle's as well: his own roof began to leak. The builder did not come. Niggle did not care; not for a day or two. Then he crawled out to look for some food (Niggle had no wife). 
que esperava que você pudesse ter tempo de ir chamar o médico, vendo como eu estou enrolado; e o pedreiro também, se realmente não tem tela para emprestar."

"Claro", disse Cisco; embora outras palavras estivessem em seu coração, que no momento estava meramente mole, sem se sentir bom de jeito nenhum. "Eu poderia ir. Eu vou, se você realmente está preocupado."

"Estou preocupado, muito preocupado. Queria não ser manco", disse Paróquia.

Assim, Cisco foi. Veja você, era complicado. Paróquia era seu vizinho, todos os outros muito distantes. Cisco tinha uma bicicleta, e Paróquia não tinha, e não conseguia usar uma. Paróquia tinha uma perna manca, uma perna manca genuína que lhe dava um bocado de dor: isso tinha de ser lembrado, assim como sua expressão enfezada e voz queixosa. Claro, Cisco tinha uma pintura e pouquíssimo tempo para terminá-la. Mas parecia que essa era uma coisa que Paróquia tinha de levar em conta, e não Cisco. Paróquia, entretanto, não levava pinturas em conta; e Cisco não podia mudar isso. "Inferno!", disse a si mesmo enquanto pegava sua bicicleta.

O tempo estava úmido e ventoso, e a luz do dia estava acabando. "Nada mais de trabalho para mim por hoje!", pensou Cisco, e, durante todo o tempo em que pedalava, ficava xingando consigo mesmo ou imaginando as passadas de seu pincel na montanha, e a ramada de folhas ao lado dela, que ele tinha imaginado pela primeira vez na primavera. Seus dedos se contorciam no guidão. Agora que estava fora do armazém, via exatamente de que maneira tratar aquele ramada brilhante que enquadrava a visão distante das montanhas. Mas tinha um sentimento de desânimo no coração, uma espécie de medo de que agora nunca teria uma chance de tentar.

Cisco achou o médico e deixou um recado para o pedreiro. O escritório estava trancado, e o pedreiro tinha ido para casa e para a sua lareira. Cisco ficou todo ensopado e pegou ele próprio uma gripe. $\mathrm{O}$ médico não partiu tão prontamente quanto Cisco. Chegou no dia seguinte, o que era bem conveniente para ele, já que então tinha dois pacientes para tratar, em casas vizinhas. Cisco estava de cama, com febre alta e padrões maravilhosos de folhas e galhos entrelaçados se formando na sua cabeça e no teto. Não o confortou saber que a sra. Paróquia tivera apenas um resfriado, e estava melhorando. Ele virou o rosto para a parede e se enterrou em folhas.

Continuou de cama por algum tempo. O vento continuou a soprar. Arrancou outro bom bocado das telhas de Paróquia, e algumas das de Cisco também: seu próprio telhado começou a gotejar. O pedreiro não veio. Cisco não se importou; não por um ou dois dias. Então se arrastou para procurar alguma comida (Cisco não tinha mulher). 
Parish did not come round: the rain had got into his leg and made it ache; and his wife was busy mopping up water, and wondering if 'that Mr. Niggle' had forgotten to call at the builder's. Had she seen any chance of borrowing anything useful, she would have sent Parish round, leg or no leg; but she did not, so Niggle was left to himself.

At the end of a week or so Niggle tottered out to his shed again. He tried to climb the ladder, but it made his head giddy. He sat and looked at the picture, but there were no patterns of leaves or visions of mountains in his mind that day. He could have painted a far-off view of a sandy desert, but he had not the energy.

Next day he felt a good deal better. He climbed the ladder, and began to paint. He had just begun to get into it again, when there carne a knock on the door.

'Damn!' said Niggle. Bur he might just as well have said 'Come in!' politely, for the door opened all the same. This time a very tall man carne in, a total stranger.

'This is a private studio,' said Niggle. 'I am busy. Go away!'

'I am an Inspector of Houses,' said the man, holding up his appoimment-card, so that Niggle on his ladder could see it.

'Oh!' he said.

'Your neighbour's house is not satisfactory at all,' said the Inspector.

'I know,' said Niggle. 'I took a note to the builders a long time ago, but they have never come. Then I have been ill.'

'I see,' said the Inspector. 'But you are not ill now.'

'But I'm not a builder. Parish ought to make a complaint to the Town Council, and get help from the Emergency Service.'

'They are busy with worse damage than any up here,' said the Inspector. 'There has been a flood in the valley, and many families are homeless. You should have helped your neighbour to make temporary repairs and prevent the damage from getting more costly to mend than necessary. That is the law. There is plenty of material here: canvas, wood, waterproof paint.'

'Where?' asked Niggle indignantly.

'There!' said the Inspector, pointing to the picture.

'My picture!' exclaimed Niggle.

'I dare say it is,' said the 1nspector. 'But houses come first. That is the law.' 
Paróquia não apareceu: a chuva tinha ensopado sua perna e a feito doer; e sua mulher estava ocupada secando a água e imaginando se "aquele Sr. Cisco" tinha esquecido de chamar o pedreiro. Se ela tivesse visto qualquer oportunidade de emprestar algo útil, teria mandado Paróquia, com ou sem perna; mas não o fez, e Cisco foi deixado em paz.

No fim de mais ou menos uma semana, Cisco cambaleou para o seu armazém de novo. Tentou subir a escada, mas isso fez sua cabeça girar. Sentou-se e olhou para a pintura, mas não havia padrões de folhas ou visões de montanhas na sua mente naquele dia. Poderia ter pintado uma visão distante de um deserto arenoso, mas não tinha energia.

No dia seguinte se sentiu bastante melhor. Subiu a escada e começou a pintar. Tinha apenas começado a entrar naquilo de novo quando veio uma batida na porta.

“Droga!", disse Cisco. Mas podia muito bem ter dito "Entre!" educadamente, pois a porta se abriu do mesmo jeito. Desse vez um homem muito alto entrou, um estranho completo.

"Este é um estúdio particular", disse Cisco. "Estou ocupado. Vá embora!"

"Sou Inspetor de Casas", disse o homem, segurando seu cartão de visitas de forma que Cisco, na sua escada, pudesse vê-lo. “Oh!”, disse ele.

"A casa de seu vizinho não está satisfatória de jeito nenhum”, disse o Inspetor.

"Eu sei”, disse Cisco. "Deixei um recado para os pedreiros há muito tempo, mas eles nunca vieram. Então fiquei doente.”

"Entendo", disse o Inspetor. "Mas você não está doente agora."

"Mas não sou pedreiro. Paróquia deveria fazer uma reclamação para o Conselho Municipal e conseguir ajuda do Serviço de Emergência."

"Eles estão ocupados com danos piores do que qualquer um aqui em cima", disse o Inspetor. "Houve uma enchente no vale, e muitas famílias estão desabrigadas. Você deveria ter ajudado seu vizinho a fazer reparos temporários e impedir que o dano ficasse mais custoso de sanar do que o necessário. Essa é a lei. Há bastante material aqui: tela, madeira, tinta a óleo."

“Onde?”, perguntou Cisco indignado.

“Ali!”, disse o Inspetor, apontando para a pintura.

"Minha pintura!", exclamou Cisco.

"Ouso dizer que é”, disse o Inspetor. "Mas casas vem primeiro. Essa é a lei." 
'But I can't. . .' Niggle said no more, for at that moment another man carne in. Very much like the Inspector he was, almost his double: tall, dressed all in black. 'Come along!' he said. 'I am the Driver.'

Niggle stumbled down from the ladder. His fever seemed to have come on again, and his head was swimming; he felt cold all over.

'Driver? Driver?' he chattered. 'Driver of what?'

'You, and your carriage,' said the man. 'The carriage was ordered long ago. It has come at last. It's waiting. You start today on your journey, you know.'

'There now!' said the Inspector. 'You'll have to go; but it's a bad way to start on your journey, leaving your jobs undone. Still, we can at least make some use of this canvas now.'

'Oh, dear!' said poor Niggle, beginning to weep. 'And it's not even finished!'

'Not finished?' said the Driver. 'Well, it's finished with, as far as you're concerned, at any rate. Come along!'

Niggle went, quite quietly. The Driver gave him no time to pack, saying that he ought to have done that before, and they would miss the train; so all Niggle could do was to grab a little bag in the hall. He found that it contained only a paint-box and a smalI book of his own sketches: neither food nor clothes. They caught the train all right. Niggle was feeling very tired and sleepy; he was hardly aware of what was going on when they bundled him into his compartment. He did not care much: he had forgotten where he was supposed to be going, or what he was going for. The train ran almost at once into a dark tunnel.

Niggle woke up in a very large, dim railway station. A Porter went along the platform shouting, but he was not shouting the name of the place; he was shouting Niggle!

Niggle got out in a hurry, and found that he had left his little bag behind. He turned back, but the train had gone away.

'Ah, there you are!' said the Porter. 'This way! What! No luggage? You will have to go to the Workhouse.' 
“Mas eu não posso..." Cisco não disse mais nada, pois naquele momento outro homem entrou. Muito semelhante ao Inspetor era ele, quase seu duplo: alto, vestido todo de preto.

"Venha comigo!", disse ele. "Sou o Condutor."

Cisco tropeçou escada abaixo. Sua febre parecia ter surgido de novo, e sua cabeça estava girando; ele se sentia todo frio.

"Condutor? Condutor?", balbuciou ele. "Condutor de quê?"

"Seu condutor, e de seu vagão", disse o homem. "O vagão foi chamado há muito tempo. Finalmente chegou. Está esperando. Você começa hoje a sua viagem, sabe.”

"Pois bem!", disse o Inspetor. "Você terá de ir; mas é um mau jeito de começar a sua viagem, deixando seus trabalhos sem terminar. Mesmo assim, podemos pelo menos dar algum uso a essa tela agora."

“Oh, nossa!”, disse o pobre Cisco, começando a chorar. "E não está nem terminada!"

"Não está terminada?", disse o Condutor. "Bem, está acabada, ${ }^{182}$ até onde lhe diz respeito, de qualquer maneira. Venha comigo!"

Cisco foi, muito quieto. O Condutor não lhe deu tempo para fazer as malas, dizendo que deveria ter feito aquilo antes, e que eles perderiam o trem; então, tudo o que Cisco conseguiu fazer foi pegar uma bolsa pequena no saguão. Descobriu que ela continha apenas uma caixa de tintas e um livrinho de seus próprios esboços: nem comida nem roupas. Eles pegaram o trem sem problemas. Cisco estava se sentindo muito cansado e com sono; mal estava ciente do que acontecia quando o amontoaram na sua cabine. Não se importou muito: tinha esquecido para onde deveria ir, ou para que estava indo. $\mathrm{O}$ trem entrou quase de cara num túnel escuro.

Cisco acordou numa estação ferroviária muito grande e sombria. Um Carregador caminhava ao longo da plataforma gritando, mas não estava gritando o nome do lugar; estava gritando Cisco!

Cisco saiu apressado, e descobriu que tinha deixado sua pequena bolsa para trás. Voltou-se, mas o trem tinha ido embora.

“Ah, aí está você!”, disse o Carregador. "Por aqui! O quê! Sem bagagem? Terá de ir para a Oficina."

${ }^{182}$ Os phrasal verbs em inglês sempre impõem desafios peculiares ao tradutor, mesmo num caso relativamente simples como esse, em que ambos fazem parte do mesmo campo semântico. O mero uso de 
Niggle felt very ill, and fainted on the platform. They put him in an ambulance and took him to the Workhouse Infirmary.

He did not like the treatment at all. The medicine they gave him was bitter. The officials and attendants were unfriendly, silent, and strict; and he never saw anyone else, except a very severe doctor, who visited him occasionally. It was more like being in a prison than in a hospital. He had to work hard, at stated hours: at digging, carpentry, and painting bare boards all one plain colour. He was never allowed outside, and the windows all looked inwards. They kept him in the dark for hours at a stretch, 'to do some thinking,' they said. He lost count of time. He did not even begin to feel better, not if that could be judged by whether he felt any pleasure in doing anything. He did not, not even in getting into bed.

At first, during the first century or so (I am merely giving his impressions), he used to worry aimlessly about the past. One thing he kept on repeating to himself, as he lay in the dark: 'I wish I had called on Parish the first morning after the high winds began. I meant to. The first loose tiles would have been easy to fix. Then Mrs. Parish might never have caught cold. Then I should not have caught cold either. Then I should have had a week longer.' But in time he forgot what it was that he had wanted a week longer for. If he worried at all after that, it was about his jobs in the hospital. He planned them out, thinking how quickly he could stop that board creaking, or rehang that door, or mend that table-leg. Probably he really became rather useful, though no one ever told him so. But that, of course, cannot have been the reason why they kept the poor little man so long. They may have been waiting for him to get better, and judging 'better' by some odd medical standard of their own.

At any rate, poor Niggle got no pleasure out of life, not what he had been used to call pleasure. He was certainly not amused. But it could not be denied that he began to have a feeling of - well satisfaction: bread rather than jam. He could take up a task the moment one bell rang, and lay it aside promptly the moment the next one went, all tidy and ready to be continued at the right time. He got through quite a lot in a day, now; he finished

uma preposição não resolve o problema na tradução - daí o uso de um verbo aparentado, a solução "contrata", digamos. 
Cisco se sentiu muito mal e desmaiou na plataforma. Eles o puseram numa ambulância e o levaram para a Enfermaria da Oficina.

Ele não gostou nem um pouco do tratamento. O remédio que lhe davam era amargo. Os funcionários e atendentes eram inamistosos, silenciosos e inflexíveis; e ele nunca via mais ninguém, exceto um médico muito severo, que o visitava ocasionalmente. Era mais como estar numa prisão do que num hospital. Ele tinha de trabalhar duro, em horas marcadas: cavar, carpintaria e pintar tábuas nuas com uma só cor simples. Ele nunca podia sair, e as janelas todas olhavam para dentro. Eles o deixavam no escuro por horas de uma vez, "para pensar um pouco", diziam. Ele perdeu a noção do tempo. Não conseguia nem começar a se sentir melhor, não se isso pudesse ser julgado pelo fato de ele sentir prazer em fazer alguma coisa. Não sentia, nem mesmo em ir para a cama.

No começo, durante o primeiro século, mais ou menos (estou apenas registrando as impressões dele), costumava se preocupar despropositadamente com o passado. Uma coisa ele ficava repetindo para si mesmo, deitado no escuro: "Queria ter chamado Paróquia na primeira manhã depois que os ventos fortes começaram. Devia. As primeiras telhas soltas seriam fáceis de consertar. Então a Sra. Paróquia nunca teria pegado resfriado. Então eu nunca teria pegado resfriado também. Então eu teria uma semana a mais." Mas com o tempo ele esqueceu para que queria uma semana a mais. Se é que ele se preocupava depois disso, era com seus trabalhos no hospital. Ele os planejava, pensando com que rapidez poderia fazer aquela tábua parar de ranger, ou ajeitar aquela porta, ou consertar aquela perna de cadeira. Provavelmente ele se tornou bastante útil, embora ninguém nunca lhe dissesse isso. Mas essa, é claro, não pode ter sido a razão pela qual seguraram o pobre homem tanto tempo. Pode ser que eles estivessem esperando que ele ficasse melhor, e julgassem "melhor" por algum padrão médico estranho deles mesmos.

Seja como for, o pobre Cisco não tinha nenhum prazer na vida, não o que ele tinha se acostumado a chamar de prazer. Ele certamente não estava se divertindo. Mas não se podia negar que ele começava a ter um sentimento de - bem, satisfação: pão em vez de geléia. Conseguia começar uma tarefa no momento em que um sino tocasse e deixá-la de lado prontamente no momento em que outro soasse, tudo arrumado e pronto para ser continuado na hora certa. Ele fazia muita coisa num dia, agora; terminava 
small things off neatly. He had no 'time of his own' (except alone in his bed-cell), and yet he was becoming master of his time; he began to know just what he could do with it. There was no sense of rush. He was quieter inside now, and at restingtime he could really rest.

Then suddenly they changed all his hours; they hardly let him go to bed at all; they took him off carpentry altogether and kept him at plain digging, day after day. He took it fairly well. It was a long while before he even began to grope in the back of his mind for the curses that he had practically forgotten. He went on digging, till his back seemed broken, his hands were raw, and he felt that he could not manage another spadeful. Nobody thanked him. But the doctor carne and looked at him.

'Knock off!' he said. 'Complete rest - in the dark.'

Niggle was lying in the dark, resting completely; so that, as he had not been either feeling or thinking at all, he might have been lying there for hours or for years, as far as he could tell. But now he heard Voices: not voices that he had ever heard before. There seemed to be a Medical Board, or perhaps a Court of Inquiry, going on dose at hand, in an adjoining room with the door open, possibly, though he could not see any light.

'Now the Niggle case,' said a Voice, a severe voice, more severe than the doctor's. 'What was the matter with him?' said a Second Voice, a voice that you might have called gentle, though it was not soft - it was a voice of authority, and sounded at once hopeful and sad. 'What was the matter with Niggle? His heart was in the right place.'

'Yes, but it did not function properly,' said the First Voice. 'And his head was not screwed on tight enough: he hardly ever thought at all. Look at the time he wasted, not even amusing himself! He never got ready for his journey. He was moderately well-off, and yet he arrived here almost destitute, and had to be put in the paupers' wing. A bad case, I am afraid. I think he should stay some time yet.' 'It would not do him any harm, perhaps,' said the Second Voice. 'But, of course, he is only a little man. He was never meant to be anything very much; and he was never very strong. Let us look at the Records. Yes. There are some favourable points, you know.'

'Perhaps,' said the First Voice; 'but very few that will really bear examination.' 
coisas pequenas facilmente. Não tinha "tempo para si" (exceto sozinho na cama de sua cela), e contudo estava se tornando mestre de seu tempo; começou a saber exatamente o que podia fazer com ele. Não havia sensação de pressa. Ele estava mais quieto por dentro agora, e na hora do descanso ele realmente conseguia descansar.

Então, de repente, eles mudaram todos os seus horários; mal o deixavam ir para a cama; tiraram-no completamente da carpintaria e o deixaram simplesmente cavando, dia após dia. Ele recebeu isso razoavelmente bem. Demorou muito tempo antes que começasse a tatear o fundo da mente em busca dos xingamentos que tinha praticamente esquecido. Continuou cavando, até que suas costas pareciam quebradas, suas mãos em carne viva, e ele sentiu que não conseguiria agüentar outro golpe de pá. Ninguém o agradeceu. Mas o médico veio e olhou para ele.

“Chega!", disse ele. "Descanso completo - no escuro."

Cisco estava deitado no escuro, descansando completamente; de forma que, como não estava nem pensando nem sentindo de jeito nenhum, poderia ter ficado deitado ali por horas ou por anos, até onde podia dizer. Mas então ele ouviu Vozes; não eram vozes que ele já tivesse ouvido antes. Parecia ser uma Junta Médica, ou talvez uma Corte de Inquérito, reunida ali perto, numa sala adjunta, com a porta aberta, possivelmente, embora ele não conseguisse ver luz nenhuma.

"Agora o caso de Cisco", disse uma Voz, uma voz severa, mais severa que a do médico.

“Qual era o problema com ele?", disse uma Segunda Voz, uma voz que se poderia chamar de gentil, embora não fosse suave - era uma voz de autoridade, e soava ao mesmo tempo esperançosa e triste. "Qual era o problema com Cisco? Seu coração estava no lugar certo.”

"Sim, mas não funcionava corretamente", disse a Primeira Voz. "E sua cabeça não estava parafusada com força suficiente: ele mal pensava. Veja só o tempo que desperdiçou, sem nem ao menos se divertir! Nunca ficou pronto para sua viagem. Ele estava moderadamente bem de vida, e contudo chegou aqui quase miserável, e teve de ser posto na ala dos indigentes. Um caso difícil, temo eu. Acho que ele deve ficar algum tempo ainda."

"Não ia lhe fazer mal nenhum, talvez", disse a Segunda Voz. "Mas, claro, ele é apenas um homenzinho. Nunca foi projetado para ser algo muito grande; e nunca foi muito forte. Vamos olhar os Registros. Sim. Há alguns pontos favoráveis, sabe.”

“Talvez", disse a Primeira Voz, "mas muito poucos que resistirão ao exame." 
'Well,' said the Second Voice, 'there are these. He was a painter by nature. In a minor way, of course; still, a Leaf by Niggle has a charm of its own. He took a great deal of pains with leaves, just for their own sake. But he never thought that that made him important. There is no note in the Records of his pretending, even to himself, that it excused his neglect of things ordered by the law.'

'Then he should not have neglected so many,' said the First Voice.

'All the same, he did answer a good many Calls.'

'A small percentage, mostly of the easier sort, and he called those Interruptions. The Records are full of the word, together with a lot of complaints and silly imprecations.'

'True; but they looked like interruptions to him, of course, poor little man. And there is this: he never expected any Return, as so many of his sort call it. There is the Parish case, the one that came in later. He was Niggle's neighbour, never did a stroke for him, and seldom showed any gratitude at all. But there is no note in the Records that Niggle expected Parish's gratitude; he does not seem to have thought about it.'

'Yes, that is a point,' said the First Voice; 'but rather small. I think you will find Niggle often merely forgot. Things he had to do for Parish he put out of his mind as a nuisance he had done with.'

'Still, there is this last report,' said the Second Voice, 'that wet bicycle-ride. I rather lay stress on that. It seems plain that this was a genuine sacrifice: Niggle guessed that he was throwing away his last chance with his picture, and he guessed, too, that Parish was worrying unnecessarily.'

'I think you put it too strongly,' said the First Voice. 'But you have the last word. It is your task, of course, to put the best interpretation on the facts. Some times they will bear it. What do you propose?'

'I think it is a case for a little gentle treatment now,' said the Second Voice.

Niggle thought that he had never heard anything so generous as that Voice. It made Gentle Treatment sound like a load of rich gifts, and the summons to a King's feast. Then suddenly Niggle felt ashamed. To hear that he was considered a case for Gentle Treatment overwhelmed him, and made him blush in the dark. It was like being publicly praised, when you and all the audience knew that the praise was not deserved. Niggle hid his blushes in the rough blanket.

There was a silence. Then the First Voice spoke to Niggle, quite close. 'You have been listening,' it said. 
"Bem", disse a Segunda Voz, "há estes aqui. Ele era um pintor por natureza. De um jeito menor, é claro; ainda assim, uma Folha de Cisco tem um charme só seu. Ele se dava uma boa dose de trabalho com folhas, só por elas mesmas. Mas nunca achou que isso o tornava importante. Não há nota alguma nos Registros de que ele fingisse, mesmo para si mesmo, que isso desculpava sua negligência com as coisas ordenadas pela lei.”

"Então ele não deveria ter negligenciado tantas", disse a Primeira Voz.

"Mesmo assim, ele chegou a responder a uma bela quantidade de Chamados."

"Uma pequena porcentagem, a maioria do tipo mais fácil, e ele os chamava de Interrupções. Os Registros estão cheios da palavra, junto com muitas reclamações e imprecações bobas."

"Verdade; mas eles lhe pareciam interrupções, é claro, pobre homenzinho. E há isto: ele nunca esperou nenhuma Recompensa, como tantos de seu tipo a chamam. Há o caso Paróquia, o que chegou mais tarde. Ele era vizinho de Cisco, nunca moveu uma palha por ele, e dificilmente mostrava alguma gratidão. Mas não há nota nos registros de que Cisco esperasse a gratidão de Paróquia; ele não parece ter pensado nisso.”

"Sim, esse é um fato", disse a Primeira Voz; "mas bem pequeno. Acho que você vai descobrir que Cisco muitas vezes simplesmente esquecia. As coisas que tinha de fazer para Paróquia ele tirava da cabeça como um obstáculo do qual se livrara."

“Ainda assim, há este último relatório", disse a Segunda Voz, "aquela corrida de bicicleta ensopado. Devo ressaltar isso. Parece claro que esse foi um sacrifício verdadeiro: Cisco percebeu que estava jogando fora sua última chance com sua pintura, e percebeu também que Paróquia estava se preocupando desnecessariamente.”

"Acho que você leva isso a sério demais", disse a Primeira Voz. "Mas você tem a última palavra. É o seu trabalho, claro, dar a melhor interpretação aos fatos. Às vezes eles a sustentam. O que propõe?"

"Acho que é o caso de um tratamentozinho gentil agora", disse a Segunda Voz.

Cisco achou que nunca ouvira nada tão generoso quanto essa Voz. Fez o Tratamento Gentil soar como uma batelada de presentes caros, e o convite para o banquete de um Rei. Então de repente Cisco sentiu vergonha. Ouvir que ele era considerado um caso de Tratamento Gentil o surpreendeu, e o fez corar no escuro. Era como ser elogiado publicamente, quando você e toda a audiência sabem que o elogio não é merecido. Cisco escondeu seu rosto vermelho no cobertor grosseiro.

Houve silêncio. Então a Primeira Voz falou com Cisco, bem perto. "Você andou escutando", disse. 
'Yes,' said Niggle.

'Well, what have you to say?'

'Could you tell me about Parish?' said Niggle. 'I should like to see him again. I hope he is not very ill? Can you cure his leg? It used to give him a wretched time. And please don't worry about him and me. He was a very good neighbour, and let me have excellent potatoes very cheap, which saved me a lot of time.'

'Did he?' said the First Voice. 'I am glad to hear it'

There was another silence. Niggle heard the Voices receding. 'Well, I agree,' he heard the First Voice say in the distance. 'Let him go on to the next stage. Tomorrow, if you like.'

Niggle woke up to find that his blinds were drawn, and his little cell was full of sunshine. He got up, and found that some comfortable clothes had been put out for him, not hospital uniform. After breakfast the doctor treated his sore hands, putting some salve on them that healed them at once. He gave Niggle some good advice, and a bottle of tonic (in case he needed it). In the middle of the morning they gave Niggle a biscuit and a glass of wine; and then they gave him a ticket.

'You can go to the railway station now,' said the doctor. 'The Porter will look after you. Good-bye.'

Niggle slipped out of the main door, and blinked a little. The sun was very bright. Also he had expected to walk out into a large town, to match the size of the station; but he did not. He was on the top of a hill, green, bare, swept by a keen invigorating wind. Nobody else was about. Away down under the hill he could see the roof of the station shining.

He walked downhill to the station briskly, but without hurry. The Porter spotted him at once.

'This way!' he said, and led Niggle to a bay, in which there was a very pleasant little local train standing: one coach, and a small engine, both very bright, dean, and newly painted. It looked as if this was their first run. Even the track that lay in front of the engine looked new: the rails shone, the chairs 
"Sim", disse Cisco.

"Bem, o que tem a dizer?"

“Pode me dizer algo sobre Paróquia?”, disse Cisco. “Gostaria de vê-lo de novo. Espero que não esteja muito doente. Vocês conseguem curar a perna dele? Costumava lhe fazer passar um mau pedaço. E por favor não se preocupem comigo e com ele. Era um vizinho muito bom, e me deixava levar batatas excelentes muito barato, o que me economizava um monte de tempo."

“É?", disse a Primeira Voz. "Fico contente de ouvir isso."

Houve outro silêncio. Cisco ouviu as vozes se afastando. "Bem, eu concordo", ouviu a Primeira Voz dizer ao longe. "Deixe-o ir para o próximo estágio. Amanhã, se você quiser."

Cisco acordou e descobriu que suas vendas tinham sido tiradas, e que sua pequena cela estava cheia da luz do sol. Levantou-se e descobriu que algumas roupas confortáveis tinham sido separadas para ele, e não o uniforme do hospital. Depois do café, o médico tratou de suas mãos inchadas, colocando um pouco de bálsamo que as curou na hora. Deu a Cisco alguns bons conselhos e uma garrafa de tônico (caso precisasse dele). No meio da manhã, deram a Cisco um biscoito e uma garrafa de vinho; e então lhe deram uma passagem.

"Pode ir para a estação de trem agora", disse o médico. "O Carregador cuidará de você. Adeus."

Cisco passou pela porta principal, e piscou um pouco. O sol estava muito forte. Ele também esperava chegar a uma cidade grande, que correspondesse ao tamanho da estação; mas não o fez. Estava no alto de uma colina, verde, limpa, varrida por um vento penetrante e revigorante. Ninguém mais estava por ali. Lá embaixo, sob a colina, conseguia ver o teto da estação brilhando.

Desceu a ladeira para a estação rapidamente, mas sem pressa. O Carregador o viu na hora.

"Por aqui!", disse, e levou Cisco para uma plataforma, na qual estava um trenzinho local muito agradável: um vagão e uma pequena locomotiva, os dois muito brilhantes, limpos e pintados recentemente. Parecia que era a primeira viagem deles. Até a estrada diante da locomotiva parecia nova: os trilhos brilhavam, os grampos 
were painted green, and the sleepers gave off a delicious smell of fresh tar in the warm sunshine. The coach was empty.

'Where does this train go, Porter?' asked Niggle.

'I don't think they have fixed its name yet,' said the Porter. 'But you'll find it all right.' He shut the door.

The train moved off at once. Niggle lay back in his seat. The little engine puffed along in a deep cutting with high green banks, roofed with blue sky. It did not se seem very long before the engine gave a whistle, the brakes were put on, and the train stopped. There was no station, and no signboard, only a flight of steps up the green embankment. At the top of the steps there was a wicket-gate in a trim hedge. By the gate stood his bicycle; at least, it looked like his, and there was a yellow label tied to the bars with NIGGLE written on it in large black letters.

Niggle pushed open the gate, jumped on the bicycle, and went bowling downhill in the spring sunshine. Before long he found that the path on which he had started had disappeared, and the bicycle was rolling along over a marvellous turf. It was green and close; and yet he could see every blade distinctly. He seemed to remember having seen or dreamed of that sweep of grass somewhere or other. The curves of the land were familiar somehow. Yes: the ground was becoming level, as it should, and now, of course, it was beginning to rise again. A great green shadow came between him and the sun. Niggle looked up, and fell off his bicycle. Before him stood the Tree, his Tree, finished. If you could say that of a Tree that was alive, its leaves opening, its branches growing and bending in the wind that Niggle had so often felt or guessed, and had so often failed to catch. He gazed at the Tree, and slowly he lifted his arms and opened them wide.

"It's a gift!" he said. He was referring to his art, and also to the result; but he was using the word quite literally.

He went on looking at the Tree. All the leaves he had ever laboured at were there, as he had imagined them rather than as he had made them; and there were others 
estavam pintados de verde, e os dormentes exalavam um cheiro delicioso de piche fresco sob o sol quente. O vagão estava vazio.

"Para onde este trem vai, Carregador?", perguntou Cisco.

"Não acho que eles tenham decidido o nome ainda", disse o Carregador. "Mas você vai descobrir, com certeza." Trancou a porta.

O trem partiu na hora. Cisco se recostou no seu assento. A pequena locomotiva bufava num barranco fundo com encostas verdes, encimado por um céu azul. Não pareceu demorar muito até que o motor deu um assobio, os freios foram acionados e o trem parou. Não havia estação nem placa, apenas um lance de escadas que ia até o alto da encosta verde. No alto dos degraus havia um portão de vime numa sebe bem cuidada. Ao lado do portão estava sua bicicleta; pelo menos parecia a sua, e havia uma placa amarela amarrada ao guidão com CISCO escrita nela em grandes letras pretas.

Cisco empurrou o portão, pulou para a bicicleta e foi rolando morro abaixo no sol de primavera. Em pouco tempo descobriu que a trilha onde tinha começado desaparecera, e a bicicleta estava rodando sobre uma relva maravilhosa. Era verde e baixa; e contudo ele conseguia ver cada folha distintamente. Parecia se lembrar de ter visto ou sonhado aquele trecho de grama em algum outro lugar. As curvas da terra eram familiares, de alguma forma. Sim: o chão estava ficando plano, como deveria, e agora estava começando a se elevar de novo. Uma grande sombra verde se pôs entre ele e o sol. Cisco olhou para cima e caiu da sua bicicleta.

Diante dele estava a Árvore, sua Árvore, terminada. ${ }^{183}$ Se é que você consegue dizer isso de uma Árvore que estava viva, suas folhas se abrindo, seus galhos crescendo e se curvando ao vento que Cisco tinha tantas vezes sentido ou intuído, e tinha tantas vezes falhado em capturar. Ele olhou para a Árvore, e lentamente ergueu os braços e os abriu ao máximo.

“É um dom!", ${ }^{184}$ disse ele. Estava se referindo à sua arte, e também ao resultado; mas estava usando a palavra de forma bem literal.

Continuou a olhar para a Árvore. Todas as folhas nas quais ele jamais ${ }^{185}$ labutara estavam lá, como ele as tinha imaginado e não como ele as tinha feito; e havia outras

\footnotetext{
${ }^{183}$ Mais uma palavra significativa, que aparece no diálogo de Cisco com Inspetor acima, e agora como contraponto irônico: a Ảrvore está terminada, mas certamente não está acabada de jeito nenhum.

${ }^{184} \mathrm{O}$ uso de trocadilhos ou sentidos duplos é quase sempre o pesadelo do tradutor. "Dádiva" ou "presente" seriam palavras melhores nesse contexto - se elas não jogassem porta afora a duplicidade de
} 
that had only budded in his mind, and many that might have budded, if only. he had had time. Nothing was written on them, they were just exquisite leaves, yet they were dated as clear as a calendar. Some of the most beautiful — and the most characteristic, the most perfect examples of the Niggle style - were seen to have been produced in collaboration with Mr. Parish: there was no other way of putting it.

The birds were building in the Tree. Astonishing birds: how they sang! They were mating, hatching, growing wings, and flying away singing into the Forest, even while he looked at them. For now he saw that the Forest was there too, opening out on either side, and marching away into the distance. The Mountains were glimmering far away.

After a time Niggle turned towards the Forest. Not because he was tired of the Tree, but he seemed to have got it all clear in his mind now, and was aware of it, and of its growth, even when he was not looking at it. As he walked away, he discovered an odd thing: the Forest, of course, was a distant Forest, yet he could approach it, even enter it, without its losing that particular charm. He had never before been able to walk into the distance without turning it into mere surroundings. It really added a considerable attraction to walking in the country, because, as you walked, new distances opened out; so that you now had doubled, treble, and quadruple distances, doubly, trebly, and quadruply enchanting. You could go on and on, and have a whole country in a garden, or in a picture (if you preferred to call it that). You could go on and on, but not perhaps for ever. There were the Mountains in the background. They did get nearer, very slowly. They did not seem to belong to the picture, or only as a link to something else, a glimpse through the trees of something different, a further stage: another picture.

Niggle walked about, but he was not merely pottering. He was looking round carefully. The Tree was finished, though not finished with-"Just the other way about to what it used to be," he thought — but in the Forest there were a number of inconclusive regions, that still needed work and thought. Nothing needed altering any longer, nothing was wrong, as far as it had gone, but it needed continuing up to a definite point. Niggle saw the point precisely, in each case.

sentido que é a chave da frase. A acepção de "presente", no entanto, também existe em português, embora seja menos utilizada.

${ }^{185}$ Em português, "jamais" também pode ter o sentido positivo do inglês ever, razão pela qual preferi essa palavra na tradução. 
que apenas tinham brotado na sua mente, e muitas que poderiam ter brotado, se ele tivesse tido tempo. Nada estava escrito nelas, eram apenas folhas soberbas, mas estavam datadas tão claramente quanto um calendário. Algumas das mais bonitas - e mais características, os exemplos mais perfeitos do estilo Cisco - tinham sido visivelmente produzidas em colaboração com o Sr. Paróquia: não havia outro jeito de colocá-lo.

Os pássaros estavam construindo na árvore. Pássaros impressionantes: como cantavam! Estavam cruzando, chocando, criando asas e voando a cantar para a Floresta, mesmo enquanto olhava para eles. Pois agora ele via que a Floresta também estava lá, espalhando-se para os dois lados, e continuando na distância. As Montanhas estavam brilhando ao longe.

Depois de um tempo Cisco se voltou para a Floresta. Não porque estivesse cansado da Árvore, mas parecia tê-la muito clara na sua mente agora, e estava ciente dela, e de seu crescimento, mesmo enquanto não estava olhando para ela. Conforme se afastava, descobriu uma coisa estranha: a Floresta, é claro, era uma Floresta distante, mas ele podia se aproximar dela, e mesmo adentrá-la, sem que perdesse esse charme particular. Ele nunca antes tinha conseguido ir para um lugar distante sem transformá-lo em simples arredores. Realmente dava uma considerável atração adicional a caminhar pelo país, porque, conforme você andava, novas distâncias se abriam; de forma que agora você tinha distâncias dobradas, triplicadas e quadruplicadas, dupla, tripla e quadruplamente encantadoras. Poderia continuar cada vez mais, ter um país inteiro num jardim, ou numa pintura (se preferisse chamá-la assim). Poderia continuar cada vez mais, mas não talvez para sempre. Havia as Montanhas no fundo. Essas ficavam mais perto, muito devagar. Não pareciam pertencer à pintura, ou apenas como ligação com algo mais, um vislumbre através das árvores de algo diferente, um próximo estágio: outra pintura.

Cisco andou por ali, mas não estava apenas vagando. Estava olhando cuidadosamente à sua volta. A Árvore estava terminada, embora não acabada "Exatamente o oposto do que costumava ser", pensou - mas na Floresta havia certo número de regiões não concluídas, que ainda precisavam de trabalho e pensamento. Nada mais precisava de alteração, nada estava errado, até onde fora, mas precisava de continuidade até um ponto definido. Cisco via a questão precisamente, em cada caso. 
He sat down under a very beautiful distant tree- a variation of the Great Tree, but quite individual, or it would be with a little more attention - and he considered where to begin work, and where to end it, and how much time was required. He could not quite work out his scheme.

"Of course!" he said. "What I need is Parish. There are lots of things about earth, plants, and trees that he knows and I don't. This place cannot be left just as my private park. I need help and advice: I ought to have got it sooner."

He got up and walked to the place where he had decided to begin work. He took off his coat. Then, down in a little sheltered hollow hidden from a further view, he saw a man looking round rather bewildered. He was leaning on a spade, but plainly did not know what to do. Niggle hailed him. "Parish!" he called.

Parish shouldered his spade and came up to him. He still limped a little. They did not speak, just nodded as they used to do, passing in the lane; but now they walked about together, arm in arm. Without talking, Niggle and Parish agreed exactly where to make the small house and garden, which seemed to be required.

As they worked together, it became-plain that Niggle was now the better of the two at ordering his time and getting things done. Oddly enough, it was Niggle who became most absorbed in building and gardening, while Parish often wandered about looking at trees, and especially at the Tree.

One day Niggle was busy planting a quickset hedge, and Parish was lying on the grass near by, looking attentively at a beautiful and shapely little yellow flower growing in the green turf. Niggle had put a lot of them among the roots of his Tree long ago. Suddenly Parish looked up: his face was glistening in the sun, and he was smiling.

"This is grand!" he said. "I oughtn't to be here, really. Thank you for putting in a word for me."

"Nonsense," said Niggle. "I don't remember what I said, but anyway it was not nearly enough." 
Ele se sentou debaixo de uma árvore distante muito bonita - uma variação da Grande Árvore, mas bastante individual, ou ficaria com um pouco mais de atenção - e considerou onde começar o trabalho, e onde terminá-lo, e quanto tempo era necessário. Não conseguia exatamente definir seu esquema.

“É claro!”, disse. “O que eu preciso é de Paróquia. Há montes de coisas sobre terra, plantas e árvores que ele sabe e eu não. Este lugar não pode ficar sendo apenas meu parque privado. Preciso de ajuda e conselho: devia ter percebido isso antes."

Ele se levantou e caminhou até o lugar onde tinha decidido começar o trabalho. Tirou seu casaco. Então, numa pequena cava protegida, oculta para quem estava mais longe, ele viu um homem que olhava em volta, bastante perdido. Estava apoiado numa pá, mas claramente não sabia o que fazer. Cisco o cumprimentou. "Paróquia!", chamou.

Paróquia colocou a pá nos ombros e veio até ele. Ainda mancava um pouco. Eles não falaram, apenas sacudiram a cabeça, como costumavam fazer, passando pela alameda; mas agora caminhavam juntos, de braço dado. Sem falar, Cisco e Paróquia concordaram exatamente sobre onde construir a pequena casa e o jardim, que pareciam ser necessários.

Conforme trabalhavam juntos, ficou claro que Cisco agora era o melhor dos dois em organizar seu tempo e terminar as coisas. Estranhamente, era Cisco que se tornara mais absorvido com construção e jardinagem, enquanto Paróquia freqüentemente vagueava olhando as árvores, e especialmente a Árvore.

Um dia, Cisco estava ocupado plantando uma muda de sebe, e Paróquia estava deitado na grama ali perto, olhando atentamente para uma florzinha amarela bela e formosa $^{186}$ que crescia na relva verde. Cisco tinha colocado um monte delas entre as raízes de sua Árvore, há muito tempo. De repente, Paróquia olhou para cima: seu rosto estava brilhando ao Sol, e ele estava sorrindo.

“Isso é genial!", disse ele. "Eu realmente não devia estar aqui. Obrigado por dar uma palavrinha por mim."

"Bobagem", disse Cisco. "Não me lembro do que disse, mas de qualquer forma não foi nem perto do suficiente."

\footnotetext{
${ }^{186}$ No presente caso, há uma estranheza inevitável quando se junta "bela" e "formosa", mas o segundo adjetivo é um decalque perfeito do inglês shapely - além de o conjunto ser uma expressão popular muito comum em português. Achei que a estranheza valia o risco.
} 
"Oh yes, it was," said Parish. "It got me out a lot sooner. That Second Voice, you know: he had me sent here; he said you had asked to see me. I owe it to you." "No. You owe it to the Second Voice," said Niggle. "We both do."

They went on living and working together: I do not know how long. It is no use denying that at first they occasionally disagreed, especially when they got tired. For at first they did sometimes get tired. They found that they had both been provided with tonics. Each bottle had the same label: A few drops to be taken in water from the Spring, before resting.

They found the Spring in the heart of the Forest; only once long ago had Niggle imagined it, but he had never drawn it. Now he perceived that it was the source of the lake that glimmered, far away and the nourishment of all that grew in the country. The few drops made the water astringent, rather bitter, but invigorating; and it cleared the head. After drinking they rested alone; and then they got up again and things went on merrily. At such times Niggle would think of wonderful new flowers and plants, and Parish always knew exactly how to set them and where they would do best. Long before the tonics were finished they had ceased to need them. Parish lost his limp.

As their work drew to an end they allowed themselves more and more time for walking about, looking at the trees, and the flowers, and the lights and shapes, and the lie of the land. Sometimes they sang together; but Niggle found that he was now beginning to turn his eyes, more and more often, towards the Mountains.

The time came when the house in the hollow, the garden, the grass, the forest, the lake, and all the country was nearly complete, in its own proper fashion. The Great Tree was in full blossom.

"We shall finish this evening," said Parish one day. "After that we will go for a really long walk."

They set out next day, and they walked until they came right through the distances to the Edge. It was not visible, of course: there was no line, or fence, or wall; but they knew that they had come to the margin of that country. They saw a man, he looked like a shepherd; he was walking towards them, down the grass-slopes that led up into the Mountains. 
“Oh, foi sim”, Paróquia. "Tirou-me de lá muito mais cedo. Aquela Segunda Voz, sabe: ela me mandou para cá; disse que você tinha pedido para me ver. Devo isso a você." "Não. Você deve isso à Segunda Voz", disse Cisco. "Nós dois devemos."

Eles continuaram a morar e trabalhar juntos: não sei por quanto tempo. Não adianta negar que no começo eles ocasionalmente discordavam, especialmente quando ficavam cansados. Pois no começo às vezes até ficavam cansados. Descobriram que ambos tinham recebido tônicos. Cada garrafa tinha o mesmo rótulo: Algumas gotas que devem ser tomadas em água da Fonte, antes de descansar.

Acharam a Fonte no coração da Floresta; só uma vez, muito tempo antes, Cisco a havia imaginado, mas nunca a desenhara. Agora percebia que era a nascente do lago que brilhava ao longe, e o sustento de tudo o que crescia no país. ${ }^{187}$ As poucas gotas tornavam a água adstringente, bastante amarga, mas revigorante; e ela limpava a cabeça. Depois de beber, descansavam sozinhos; e então se levantavam de novo, e as coisas iam adiante alegremente. Nessas horas Cisco pensava em flores e plantas novas e maravilhosas, e Paróquia sempre sabia exatamente como plantá-las e onde elas dar-seiam melhor. Muito antes que os tônicos acabassem, eles tinham deixado de precisar deles. Paróquia parou de mancar.

Conforme o trabalho deles se aproximava do fim, permitiam-se mais e mais tempo para caminhar, olhando as árvores, e as flores, e as luzes e formas, e o traçado da terra. Às vezes cantavam juntos; mas Cisco descobriu que estava começando a voltar seus olhos, com mais e mais freqüência, na direção das montanhas.

O tempo chegou quando a casa na cava, o jardim, a grama, a floresta, o lago e todo o país estavam quase completos, do seu próprio jeito certo. A Grande Árvore estava toda em flor.

"Vamos terminar nesta tarde", disse Paróquia um dia. "Depois disso vamos fazer uma caminhada realmente longa."

Eles partiram no dia seguinte, e caminharam toda a distância até a Borda. Não era visível, claro: não havia linha, ou cerca, ou muro; mas sabiam que tinham chegado à margem daquele país. Viram um homem, ele parecia um pastor; ${ }^{188}$ estava caminhando na direção deles, descendo as encostas gramadas que levavam às Montanhas.

\footnotetext{
${ }^{187}$ A palavra country, recorrente, é famosa por admitir uma multiplicidade de traduções para o português, mas tentei utilizá-la da forma mais consistente possível. A escolha de "país" se explica pela necessidade de circunscrever o espaço onde os dois personagens se reencontram. Que se trata de um local "à parte" fica claro pelo fato de que ele ganha um nome próprio todo especial na conclusão do conto.

${ }^{188}$ A conotação religiosa - "o Bom Pastor" - é óbvia.
} 
"Do you want a guide?" he asked. "Do you want to go on?"

For a moment a shadow fell between Niggle and Parish, for Niggle knew that he did now want to go on, and (in a sense) ought to go on; but Parish did not want to go on, and was not yet ready to go.

"I must wait for my wife," said Parish to Niggle. "She'd be lonely. I rather gathered that they would send her after me, some time or other, when she was ready, and when I had got things ready for her. The house is finished now, as well as we could make it; but I should like to show it to her. She'll be able to make it better, I expect: more homely. I hope she'll like this country, too." He turned to the shepherd. "Are you a guide?" he asked. "Could you tell me the name of this country?"

"Don't you know?" said the man. "It is Niggle's Country. It is Niggle's Picture, or most of it: a little of it is now Parish's Garden."

"Niggle's Picture!" said Parish in astonishment. "Did you think of all this, Niggle? I never knew you were so clever. Why didn't you tell me?"

"He tried to tell you long ago," said the man; "but you would not look. He had only got canvas and paint in those days, and you wanted to mend your roof with them. This is what you and your wife used to call Niggle's Nonsense, or That Daubing."

"But it did not look like this then, not real," said Parish.

"No, it was only a glimpse then," said the man; "but you might have caught the glimpse, if you had ever thought it worth while to try."

"I did not give you much chance," said Niggle. "I never tried to explain. I used to call you Old Earth-grubber. But what does it matter? We have lived and worked together now. Things might have been different, but they could not have been better. All the same, I am afraid I shall have to be going on. We shall meet again, I expect: there must be many more things we can do together. Good-bye!" He shook Parish's hand warmly: a good, firm, honest hand it seemed. He turned and looked back for a moment. The blossom on the Great Tree was shining like flame. All the birds were flying in the air and singing. Then he smiled, and nodded to Parish, and went off with the shepherd.

He was going to learn about sheep, and the high pasturages, and look at a wider sky, and walk ever further and further towards the Mountains, always uphill. Beyond that I cannot guess what became of him. Even little Niggle in his old home 
"Querem um guia?”, perguntou. "Querem continuar?”

Por um momento uma sombra caiu entre Cisco e Paróquia, pois Cisco sabia que agora queria continuar e (em certo sentido) devia continuar; mas Paróquia não queria continuar, e ainda não estava pronto para ir.

"Tenho de esperar minha esposa", disse Paróquia para Cisco. "Ele iria se sentir solitária. Eu meio que achava que eles iriam mandá-la atrás de mim, num momento ou outro, quando estivesse pronta, e quando eu tivesse preparado as coisas para ela. A casa está terminada agora, tão bem quanto pudemos criá-la; mas eu gostaria de mostrá-la a ela. Ela vai ser capaz de torná-la melhor, espero: mais caseira. Espero que ela goste deste país também." Ele se voltou para o pastor. "Você é um guia?", perguntou. "Poderia me dizer o nome deste país?"

"Você não sabe?", disse o homem. "É País de Cisco. Esta é a Pintura de Cisco, ou a maior parte dela: um pouco dela é agora o Jardim de Paróquia.”

“A Pintura de Cisco!”, disse Paróquia em assombro. "Você pensou em tudo isso, Cisco? Nunca imaginei que fosse tão inteligente. Por que não me disse?”

"Ele tentou lhe dizer há muito tempo", disse o homem; "mas você não queria olhar. Ele só tinha tela e tinta naqueles dias, e você queria consertar seu teto com elas. Isto é o que você e sua esposa costumavam chamar de Bobagem de Cisco, ou Aquele Borrão."

"Mas não parecia assim então, não real", disse Paróquia.

"Não, era só um vislumbre então", disse o homem; "mas você poderia ter capturado o vislumbre, se alguma vez tivesse achado que valia tentar".

"Eu não the dei muita chance", disse Cisco. "Nunca tentei explicar. Costumava chamar você de Velho Cavador de Terra. Mas o que importa? Vivemos e trabalhamos juntos agora. As coisas poderiam ter sido diferentes, mas não poderiam ter sido melhores. Mesmo assim, temo que terei de ir em frente. Vamos nos encontrar de novo, espero: deve haver muito mais coisas que possamos fazer juntos. Adeus!”. Ele apertou a mão de Paróquia de maneira calorosa: uma mão boa, firme e honesta pareceu. Voltou-se e olhou para trás por um momento. A florada na Grande Árvore brilhava como chama. Todos os pássaros estavam voando no ar e cantando. Então ele sorriu, sacudiu a cabeça para Paróquia e partiu com o pastor.

Ia aprender sobre ovelhas, e as pastagens altas, e olhar para um céu mais amplo, e caminhar para cada vez mais e mais perto das Montanhas, sempre morro acima. Além disso não consigo adivinhar o que foi dele. Até o pequeno Cisco em seu antigo lar 
could glimpse the Mountains far away, and they got into the borders of his picture; but what they are really like, and what lies beyond them, only those can say who have climbed them.

'I think he was a silly little man,' said Councillor Tompkins. 'Worthless, in fact; no use to Society at all.'

'Oh, I don't know,' said Atkins, who was nobody of importance, just a schoolmaster. 'I am not so sure: it depends on what you mean by use.'

'No practical or economic use,' said Tompkins. 'I dare say he could have been made into a serviceable cog of some sort, if you schoolmasters knew your business. But you don't, and so we get useless people of his sort. If I ran this country I should put him and his like to some job that they're fit for, washing dishes in a communal kitchen or something, and I should see that they did it properly. Or I would put them away. I should have put him away long ago.'

'Put him away? You mean you'd have made him start on the joumey before his time?'

'Yes, if you must use that meaningless old expression. Push him through the tunnel imo the great Rubbish Heap: that's what I mean.'

'Then you don't think painting is worth anything, not worth preserving, or improving, or even making use of?'

'Of course, painting has uses,' said Tompkins. 'But you couldn't make use of his painting. There is plenty of scope for bold young men not afraid of new ideas and new methods. None for this old-fashioned stuff. Private day-dreaming. He could not have designed a telling poster to save his life. Always fiddling with leaves and flowers. I asked him why, once. He said he thought they were pretty! Can you believe it? He said pretty! "What, digestive and genital organs of plants?" I said to him; and he had nothing to answer. Silly footler.'

'Footler,' sighed Atkins. 'Yes, poor little man, he never finished anything. Ah well, his canvases have been put to "better uses", since he went. 
conseguia vislumbrar as Montanhas ao longe, e elas ficaram nas fronteiras de sua pintura; mas como elas realmente são, e o que jaz além delas, só podem dizer os que as escalaram.

“Acho que ele era um homenzinho tolo", disse o Conselheiro Tomasim ${ }^{189}$. "Sem valor, na verdade; sem utilidade alguma para a Sociedade."

“Oh, não sei”, disse Alvim, que não era ninguém importante, só um mestreescola. 190 "Não tenho tanta certeza; depende do que você quer dizer com utilidade."

"Nenhuma utilidade prática ou econômica", disse Tomasim. "Ouso dizer que ele poderia ser transformado numa engrenagem útil de algum tipo, se vocês mestres-escolas fizessem seu trabalho. Mas não fazem, e então temos pessoas inúteis desse tipo. Se eu mandasse neste país, colocaria a ele e aos de sua laia em algum serviço para o qual fossem adequados, lavando pratos numa cozinha comunitária ou algo assim, e certificarme-ia de que o fizessem direito. Ou iria guardá-los. Eu devia tê-lo guardado há muito tempo."

“Guardado? Quer dizer que iria fazê-lo começar a jornada antes do tempo dele?"

"Sim, se você quer usar essa velha expressão sem sentido. Empurrá-lo pelo túnel até o grande Monte de Lixo: é isso o que quero dizer."

"Então você não acha que a pintura vale alguma coisa, não vale ser preservada, melhorada ou mesmo utilizada?"

“Claro, pintar tem suas utilidades", disse Tomasim. "Mas você não conseguiria dar uma utilidade à pintura dele. Há escopo de sobra para jovens ousados sem medo de novas idéias e novos métodos. Nenhum para essa coisa antiquada. Devaneio particular. Ele não conseguiria desenhar um pôster de propaganda para salvar a própria vida. Sempre mexendo com folhas e flores. Perguntei a ele por que, uma vez. Ele disse que as achava bonitas! Dá para acreditar? Ele disse bonitas! "O que, órgãos digestivos e genitais de plantas?”, disse a ele; e ele não teve nada para responder. Enrolador tonto.”

"Enrolador", suspirou Alvim. "Sim, pobre homenzinho, ele nunca terminava nada. Ah, bem, suas telas foram empregadas para 'usos melhores', desde que partiu.

\footnotetext{
${ }^{189}$ Os sobrenomes têm um ar banal e parecem ter sido feitos sob medida para sugerir falta de individualidade, a julgar pelas terminações idênticas. Todos são formados por contração de nome pessoal + patronímico (filho de Thomas, filho de Peter, filho de Arthur), mais um sufixo diminutivo; daí os sobrenomes em português, cujo processo de formação é quase idêntico. Por uma questão de coerência, estão traduzidos, como Cisco e Paróquia.

${ }^{190}$ A palavra soa um tanto estranha nesse contexto, há que se admitir, mas a alternativa - professor primário? - realmente acaba revelando-a como a melhor opção, creio eu.
} 
But I am not so sure, Tompkins. You remember that large one, the one they used to patch the damaged house next door to his, after the gales and floods? I found a comer of it torn off, lying in a field. It was damaged, but legible: a mountain-peak and a spray of leaves. I can't get it out of my mind.'

'Out of your what?' said Tompkins.

'Who are you two talking about?' said Perkins, intervening in the cause of peace: Atkins had flushed rather red.

'The name's not worth repeating,' said Tompkins. 'I don't know why we are talking about him at all. He did not live in town.'

'No,' said Atkins; 'but you had your eye on his house, all the same. That is why you used to go and call, and sneer at him while drinking his tea. Well, you've got his house now, as well as the one in town, so you need not grudge him his name. We were talking about Niggle, if you want to know, Perkins.'

'Oh, poor little Niggle!' said Perkins. 'Never knew he painted.'

That was probably the last time Niggle's name ever came up in conversation. However, Atkins preserved the odd comer. Most of it crumbled; but one beautiful leaf remained intact. Atkins had it framed. Later he left it to the Town Museum, and for a long while "Leaf: by Niggle" hung there in a recess, and was noticed by a few eyes. But eventually the Museum was burnt down, and the leaf, and Niggle, were entirely forgotten in his old country.

'It is proving very useful indeed,' said the Second Voice. 'As a holiday, and a refreshment. It is splendid for convalescence; and not only for that, for many it is the best introduction to the Mountains. It works wonders in some cases. I am sending more and more there. They seldom have to come back.'

'No, that is so,' said the First Voice. 'I think we shall have to give the region a name. What do you propose?'

'The Porter settled that some time ago,' said the Second Voice. 'Train for Niggle's Parish in the bay: he has shouted that for a long while now. Niggle's Parish. I sent a message to both of them to tell them.'

'What did they say?' 
Mas não tenho tanta certeza, Tomasim. Lembra-se da grande, a que eles usaram para cobrir a casa danificada vizinha da dele, depois dos vendavais e enchentes? Achei um canto dela rasgado, caído num campo. Estava danificado, mas visível: o pico de uma montanha e folhas ao vento. Não consigo tirá-la da minha cabeça."

"Da sua o quê?", disse Tomasim.

"Sobre quem vocês dois estão falando?", disse Pedrim, intervindo em nome da paz; Alvim tinha ficado bastante vermelho.

“O nome não vale a pena repetir", disse Tomasim. "Não sei nem por que estamos falando dele. Não morava na cidade."

"Não", disse Alvim; "mas você estava de olho na casa dele mesmo assim. É por isso que você costumava ir visitá-lo, e troçar dele enquanto bebia seu chá. Bem, você tem a casa dele, agora, assim como a da cidade, então não precisa negar-lhe o nome. Estávamos falando de Cisco, se quer saber, Pedrim.”

“Oh, pobrezinho do Cisco!", disse Pedrim. "Nunca soube que ele pintava."

Essa foi provavelmente a última vez que o nome de Cisco apareceu numa conversa. Entretanto, Alvim preservou o canto estranho. A maior parte dele se desmanchou; mas uma folha bonita permaneceu intacta. Alvim mandou enquadrá-la. Mais tarde ele a deixou para o Museu da Cidade, e por muito tempo "Folha: de Cisco" ficou lá pendurada num recesso, e foi notada por uns poucos olhos. Mas finalmente o Museu foi queimado, e a folha, e Cisco, foram completamente esquecidos no antigo país dele.

"Está se provando realmente muito útil, de fato", disse a Segunda Voz. "Como um feriado, e um refrigério. ${ }^{191}$ É esplêndido para convalescência; e não apenas para isso, para muitos é a melhor introdução às montanhas. Opera maravilhas em alguns casos. Estou mandando mais e mais para lá. Eles raramente precisam voltar.”

"Não, é assim mesmo", disse a Primeira Voz. "Acho que teremos de dar um nome ao país. O que você propõe?”

"O Carregador resolveu isso há algum tempo", disse a Segunda Voz. "Trem para Paróquia de Cisco na plataforma: ele anda gritando isso já faz tempo. Paróquia de Cisco. Mandei uma mensagem a ambos para contar a eles."

"O que disseram?"

\footnotetext{
${ }^{191}$ Outra palavra com tons religiosos que, na minha opinião, encaixa-se perfeitamente no tom geral do conto, além de ter parentesco com o termo em inglês.
} 
'They both laughed. Laughed - the Mountains rang with it!' 
"Ambos riram. Riram - as Montanhas chacoalharam com aquilo!" 


\section{Homecoming of Beorhtnoth Beorhthelm's Son}

Publicado pela primeira vez em 1953 e logo transformado em adaptação radiofônica pela BBC, The Homecoming of Beorhtnoth Beorhthelm's Son é provavelmente o único texto em forma dramática escrito por Tolkien - mas é claro que seu interesse vai muito além disso. Na verdade, trata-se de uma continuação imaginária de um poema do fim do período anglo-saxão (fim do século X, começo do século XI; é difícil estimar a data exata). Esse texto é conhecido como A Batalha de Maldon, e é um fragmento sem começo nem conclusão, com 325 linhas.

Ao contrário da maioria dos poemas heróicos, seu tema é uma derrota sofrida pelos ingleses contra os vikings perto de Maldon, uma vila de Essex. Quem liderava os ingleses era o duque Beorhtnoth, filho de Beorhthlem, a quem o título do poema tolkieniano se refere. O texto original acaba depois que o duque tomba e os guerreiros de sua guarda pessoal vão morrendo, um a um, na tentativa de proteger seu corpo.

Tolkien retoma a narrativa nesse momento, partindo do ponto de vista de dois servos de Beorhtnoth, Tídwald (ou Tída) e Torhthelm (mais conhecido como Totta), que vão tentar recuperar o corpo de seu senhor no campo de batalha para tentar dar a ele um enterro digno. É como se o autor tentasse criar um contraponto dos não-combatentes à batalha, e ambos os falantes que se revezam nos diálogos também têm vozes bastante diferentes, que se contrapõem Totta é um jovem que está com a cabeça cheia das antigas canções heróicas de seu povo, e exprime uma visão romantizada da guerra; queria ter participado da luta e diz isso seguidas vezes. Já Tída é um velho ceorl (camponês livre), que perdeu todas as ilusões desse tipo depois de presenciar décadas de combate. ${ }^{192}$

O texto é fundamentalmente uma recuperação do universo heróico anglo-saxão e um comentário irônico (bittersweet seria a palavra exata) a respeito dele, e a própria existência desse universo brota do verso aliterativo - razão pela qual tentei reproduzi-lo aqui. Além disso, o poema é também um réquiem para esse mundo e para o tipo de literatura que o epitomizava; tanto é assim que seus últimos versos em inglês (há também um epílogo curto em latim) são em versos rimados, sinalizando o ocaso da antiga tradição poética. O traço de modernidade mais marcante nessa "reconstrução" tolkieniana é que a forma dramática, com marcações de cena, era absolutamente

\footnotetext{
192 É interessante como, mais uma vez, os nomes próprios dos personagens ajudam a compor o quadro da narrativa. Assim, o nome do jovem Torhthelm quer dizer "elmo reluzente"; o do maduro e desiludido Tídwald pode ser traduzido como "o governo do tempo, aquele que governa pelo tempo".
} 
impensável na antiga poesia heróica da Inglaterra. Assim, enquanto o metro em si é recriado com exatidão, a maneira como ele é apresentado difere radicalmente do que as audiências do século XI esperariam encontrar.

A tradução apresentada a seguir é uma das primeiras tentativas de utilizar a métrica aliterativa anglo-saxã em português, e em poucos casos o velho ditado easier said than done se provou mais verdadeiro. Embora a base utilizada para chegar ao resultado desta dissertação tenha sido sempre a gerada pelos seis tipos clássicos de meia-linha, certo grau de adaptação tornou-se inevitável. De fato, a experiência mostrou como as formas poéticas, em sua origem, devem muito à própria estrutura da língua onde são criadas. Os tipos-padrão de meias-linhas parecem ter surgido, nos idiomas germânicos, do fato praticamente seguro de que a sílaba tônica é também a primeira da palavra, e da abundância de palavras curtas, monossílabos e dissílabos. Assim, é muito mais fácil estruturar as meias-linhas do tipo D (que exigem duas tônicas seguidas sem, normalmente, átonas entre elas) em inglês antigo ou moderno do que em português.

Outra questão importante, que afeta todos os tipos de meia-linha, é o problema da duração silábica (a presença de sílabas breves e longas) em português. Os estudos mais recentes de fonética sugerem que, em português falado do Brasil (a variante falada é a que interessa porque as meias-linhas se baseiam em padrões naturais da fala), as sílabas tônicas são automaticamente pronunciadas como longas sempre (MASSINICAGLIARI, 2006, comunicação pessoal). Até aí tudo bem: isso significa que, na prática, qualquer sílaba tônica pode servir como um lift em português brasileiro. A questão se complica, no entanto, caso se deseje utilizar o recurso de "quebrar" um lift em duas sílabas, uma tônica curta e outra átona, uma vez que toda tônica acaba sendo "ouvida" como longa. Perde-se, assim, em flexibilidade. Para compensar esse problema, o leitor notará que, em algumas das segundas meias-linhas (mas não todas), a escansão vai apenas até a última sílaba tônica, deixando uma átona de fora. Pode-se considerar que esse recurso métrico, obrigatório na versificação tradicional em português, é incorporado como um equivalente da "quebra" dos lifts na métrica aliterativa original. Em vários casos em que esse problema chegava perto de acontecer no interior das linhas, e não no fim, o uso da elisão (outro recurso pouco disponível em inglês) evitou maiores problemas.

Além disso, ainda há um debate indeciso sobre a precisa natureza das subtônicas ou tônicas secundárias em português, o que atrapalha a composição de qualquer meialinha dos tipos $\mathrm{Da}, \mathrm{Db}$ e $\mathrm{E}$, que dependem das tônicas secundárias. A posição 
consensual hoje parece ser a de admitir subtônicas apenas nas palavras compostas e derivadas (em passarinho, por exemplo, a tônica da palavra original viraria subtônica no caso, a sílaba $p a$ ). Levando em consideração apenas essa possibilidade, torna-se praticamente impossível criar meias-linhas $\mathrm{Da}, \mathrm{Db}$ ou E. É por isso que, seguindo o que acontece com as proparoxítonas do inglês antigo, cuja estrutura fonética é bastante parecida com a das proparoxítonas em português, que decidi incluir certo elemento de artificialidade para compor esse tipo de hemistíquio. Assim, proparoxítonas como célere seriam escandidas como "t-s-a" - "cé-lè-re".

Finalmente, uma questão inesperada mas que requer resolução é o que fazer com lifts cuja "rima" é composta por fonemas inexistentes em português. Isso ocorre com nomes próprios que têm de ser mantidos na tradução, como Woden e Wulfmær. Como se trata de uma semivogal, passei a considerar que a aliteração com vogais é válida.

Questões pontuais sobre cada verso serão tratadas na forma de notas. 


\section{THE HOMECOMING OF BEORHTNOTH BEORHTHELM'S SON}

\section{BEORHTNOTH'S DEATH}

In August of the year 991, in the reign of Æthelred II, a battle was fought near Maldon in Essex. On the one side was the defence-force of Essex, on the other a viking host that had ravaged Ipswich. The English were commanded by Beorhtnoth son of Beorhthelm, the duke of Essex, a man renowned in his day: powerful, fearless, proud. He was now old and hoar, but vigorous and valiant, and his white head towered high above other men, for he was exceedingly tall. ${ }^{193}$ The 'Danes' - they were on this occasion probably for the most part Norwegians - were, according to one version of the Anglo-Saxon Chronicle, 1ed by Anlaf, famous in Norse saga and history as Olaf Tryggvason, later to become King of Norway. ${ }^{194}$ The Northmen had sailed up the estuary of the Pante, now called the Blackwater, and encamped on Northey Island. The Northmen and the English were thus separated by an arm of the river; filled by the incoming tide, it could only be crossed by a 'bridge' or causeway, difficult to force in the face of a determined defence. ${ }^{195}$ The defence was resolute. But the vikings knew, or so it would seem, what manner of a man they had to deal with: they asked for leave to cross the ford, so that a fair fight could be joined. Beorhtnoth accepted the challenge and allowed them to cross. This act of pride and misplaced chivalry proved fatal. Beorhtnoth was slain and the English routed; but the duke's 'household', his heorðwerod, containing the picked knights and officers of his bodyguard, some of them members of his own family, fought on, until they all fell dead beside their lord.

A fragment - a large fragment, 325 lines long - of a contemporary poem has been preserved: it has no end and no beginning, and no title, but is now generally known as The Battle of Maldon. It tells of the demand of the vikings for tribute in return for peace; of Beorhtnoth's proud refusal, and challenge, and the defence of

\footnotetext{
${ }^{193}$ According to one estimate 6 foot 9 inches tall. This estimate was based on the length and size of his bones when examined, in his tomb at Ely, in AD 1769.

${ }^{194}$ That Olaf Tryggvason was actually present at Maldon is now thought to be doubtful. But his name was known to Englishmen. He had been in Britain before, and was certainly here again in 994.

195 According to the views of E. D. Laborde, now generally accepted. The causeway or 'hard' between Northey and the mainland is still there.
} 


\section{O RETORNO DE BEORHTNOTH, FILHO DE BEORHTHELM}

\section{A MORTE DE BEORHTNOTH}

EM agosto do ano 991, no reinado de Aethelred II, uma batalha foi travada perto de Maldon em Essex. De um lado estava a força de defesa de Essex, de outro uma hoste viking que devastara Ipswich. Os ingleses eram comandados por Beorhtnoth, filho de Beorhthelm, o duque de Essex, um homem renomado em sua época: poderoso, destemido, orgulhoso. Estava agora velho e grisalho, mas vigoroso e valente, e sua cabeça branca se levantava muito acima de outros homens, pois ele era excepcionalmente alto ${ }^{196}$. Os "daneses" - eles eram nessa ocasião na maior parte noruegueses - eram, de acordo com uma versão da Crônica Anglo-Saxã, liderados por Anlaf, famoso na saga e história nórdicas como Olaf Tryggvason, depois rei da Noruega. ${ }^{197}$ Os nortistas haviam subido o estuário do Pante, hoje chamado de Blackwater, e acamparam na ilha Northey. Os nortistas e os ingleses estavam assim separados por um braço do rio; enchido pela maré que subia, ele só podia ser cruzado por uma "ponte" ou rampa, difícil de forçar diante de uma defesa determinada. ${ }^{198}$ A defesa era resoluta. Mas os vikings sabiam, ou é o que parece, com que sorte de homem tinham de lidar: pediram permissão para cruzar o vau, de forma que uma luta justa pudesse acontecer. Beorhtnoth aceitou o desafio e permitiu que atravessassem. Esse ato de orgulho e cavalheirismo deslocado se provou fatal. Beorhtnoth foi morto e os ingleses dispersados; mas a "casa" do duque, seu heorthwerod, contendo os cavaleiros e oficiais escolhidos de sua guarda pessoal, alguns dos quais membros de sua própria família, continuou a lutar, até que todos caíram mortos ao lado de seu senhor.

Um fragmento - um fragmento grande, com 325 linhas - de um poema contemporâneo foi preservado - não tem fim nem começo, nem título, mas agora é geralmente conhecido como A Batalha de Maldon. Fala da exigência de tributo dos vikings em troca de paz; da orgulhosa recusa e do desafio de Beorhtnoth, e da defesa da

\footnotetext{
${ }^{196}$ De acordo com uma estimativa, $1,98 \mathrm{~m}$. Essa estimativa foi baseada no comprimento e tamanho de seus ossos quando examinados, em seu túmulo em Ely, em 1769.

${ }^{197}$ Que Olaf Tryggvason esteve realmente presente em Maldon é agora considerado duvidoso. Mas seu nome era conhecido dos ingleses. Ele estivera na Grã-Bretanha antes, e certamente esteve aqui de novo em 994.

${ }^{198}$ De acordo com as idéias de E.D. Laborde, hoje geralmente aceitas. A rampa ou "mole" entre Northey e a terra firme ainda está lá.
} 
the 'bridge'; the cunning request of the vikings, and the crossing of the causeway; the last fight of Beorhtnoth, the falling of his golden-hilted sword from his maimed hand, and the hewing of his body by the heathen men. The end of the fragment, almost half of it, tells of the last stand of the bodyguard. The names, deeds, and speeches of many of the Englishmen are recorded.

The duke Beorhtnoth was a defender of the monks, and a patron of the church, especially of the abbey of Ely. After the battle the Abbot of Ely obtained his body and buried it in the abbey. His head had been hacked off and was not recovered; it was replaced in the tomb by a ball of wax.

According to the late, and largely unhistorical, account in the twelfth-century Liber Eliensis, the Abbot of Ely went himself with some of his monks to the battlefield. But in the following poem it is supposed that the abbot and his monks came only as far as Maldon, and that they there remained, sending two men, servants of the duke, to the battlefield some distance away, late in the day after the battle. They took a waggon, and were to bring back Beorhtnoth's body. They left the waggon near the end of the causeway and began to search among the slain: very many had fallen on both sides. Torhthelm (colloquially Totta) is a youth, son of a minstrel; his head is full of old lays concerning the heroes of northern antiquity, such as Finn, king of Frisia; Fróda of the Hathobards; Béowulf; and Hengest and Horsa, traditional leaders of the English Vikings in the days of Vortigern (called by the English Wyrtgeorn). Tídwald (in short Tída) was an old ceorl, a farmer who had seen much fighting in the English defence-levies. Neither of these men were actually in the battle. After leaving the waggon they became separated in the gathering dusk. Night falls, dark and clouded. Torhthelm is found alone in a part of the field where the dead lie thick.

From the old poem are derived the proud words of Offa at a council before the battle, and the name of the gallant young Aelfwine (scion of an ancient noble house in Mercia) whose courage was commended by Offa. There also are found the names of the two Wulfmaers: Wulfmaer, son of Beorhtnoth's sister; and Wulfmaer the young, son of Wulfstan, who together with Aelfnoth fell grievously hewn beside Beorhtnoth. Near the end of the surviving fragment an old retainer, Beorhtwold, as he prepares to die in the last desperate stand, utters the famous words, a summing up of the heroic code, that are here spoken in a dream by Torhthelm:

Hige sceal De heardra, heorte Pe cenre 
"ponte"; do pedido matreiro dos vikings, e da travessia da rampa; da última luta de Beorhtnoth, da queda de sua espada de punho dourado de sua mão aleijada e da mutilação de seu corpo pelos homens pagãos. O fim do fragmento, quase a metade dele, fala do último combate da guarda pessoal. Os nomes, feitos e falas de muitos dos ingleses estão registrados. O duque Beorhtnoth era um defensor dos monges, e um patrono da Igreja, especialmente da abadia de Ely. Depois da batalha o abade de Ely obteve seu corpo e o enterrou na abadia. Sua cabeça tinha sido decepada e não foi recuperada; foi substituída no túmulo por uma bola de cera.

De acordo com o relato tardio e em grande parte não-histórico do Liber Eliensis, do século XII, o próprio abade de Ely foi com alguns de seus monges para o campo de batalha. Mas no poema a seguir supõe-se que o abade e seus monges só chegaram até Maldon, e que lá permaneceram, mandando dois homens, servos do duque, para o campo de batalha a alguma distância, tarde do dia depois da batalha. Eles levaram uma carroça e deviam trazer de volta o corpo de Beorhtnoth. Deixaram a carroça perto do fim da rampa e começaram a procurar entre os mortos; muitíssimos haviam tombado de ambos os lados. Tohrthelm (coloquialmente Totta) é um jovem, filho de menestrel; sua cabeça está cheia de antigas lais acerca dos heróis da antigüidade nortista, tais como Finn, rei da Frísia; Fróda dos hatobardos; Béowulf; e Hengest e Horsa, líderes tradicionais dos vikings ingleses nos dias de Vortigern (chamado pelos ingleses de Wyrtgeorn). Tídwald (encurtado para Tída) era um velho ceorl, um fazendeiro que tinha visto muita luta nas milícias de defesa inglesas. Nenhum desses homens tinha chegado a estar na batalha. Depois de deixar a carroça, eles se separaram no crepúsculo que chegava. A noite cai, escura e nublada. Torhthelm se acha sozinho numa parte do campo onde os mortos jazem aos montes.

Do velho poema são derivadas as palavras orgulhosas de Offa num conselho antes da batalha, e o nome do valente e jovem Aelfwine (varão de uma antiga casa nobre de Mércia) cuja coragem era elogiada por Offa. Lá também são encontrados os nomes dos dois Wulfmaers: Wulfmaer, filho da irmã de Beorhtnoth; e Wulfmaer, o jovem, filho de Wulfstan, que ao lado de Aelfnoth tombou duramente ferido ao lado de Beorhtnoth. Perto do fim do fragmento sobrevivente um velho servidor, Beorhtwold, enquanto se prepara para morrer no último combate desesperado, pronuncia as palavras famosas, um resumo do código heróico, que aqui são ditas num sonho por Torhthelm: 


\section{Mod sceal Pe mare Pe ure maegen lytlað}

'Will shall be the sterner, heart the bolder, spirit the greater as our strength lessens.'

It is here implied, as is indeed probable, that these words were not 'original', but an ancient and honoured expression of heroic will; Beorhtwold is all the more, not the less, likely for that reason actually to have used them in his last hour.

The third English voice in the dark, speaking after the Dirige is first heard, uses rhyme: presaging the fading end of the old heroic alliterative measure. The old poem is composed in a free form of the alliterative line, the last surviving fragment of ancient English heroic minstrelsy. In that measure, little if at all freer (though used for dialogue) than the verse of The Battle of Maldon, the present modern poem is written.

The rhyming lines are an echo of some verses, preserved in the Historia Eliensis, referring to King Canute:

Merie sungen ðe muneches binnen Ely

Oa Cnut ching reu ðerby.

'Roweð, cnites, noer the land

and here we ther muneches saeng'

(II) THE HOMECOM1NG OF BEORHTNOTH BEORHTHELM'S SON

The sound is heard of a man moving uncertainly and breathing noisily in the darkness. Suddenly a voice speaks, loudly and sharply.

\section{TORHTHELM.}

Halt! What do you want? Hell take you! Speak!

TÍDWALD.

Totta! I know you by your teeth rattling. 
Mod sceal De mare De ure maegen lytlað

“A vontade será mais dura, o coração mais ousado, o espírito maior conforme nossa força diminui."

Está implicado aqui, como de fato é provável, que essas palavras não eram “originais", mas uma expressão antiga e honrada de vontade heróica; é muito mais, e não menos, provável que Beorhtwold, por essa razão, as tenha realmente usado em sua hora final.

A terceira voz inglesa no escuro, falando depois que o Dirige é ouvido pela primeira vez, usa rima: pressagiando o fim desvanecente da antiga medida aliterativa. $\mathrm{O}$ velho poema está composto numa forma livre do verso aliterativo, o último fragmento sobrevivente do antigo cancioneiro heróico inglês. Nessa medida, pouco ou nada mais livre que o verso de A Batalha de Maldon (embora usada para diálogos), o poema moderno está escrito.

As linhas que rimam são um eco de alguns versos, preservados na Historia Eliensis, referentes ao rei Canuto:

Merie sungen ðe muneches binnen Ely

Oa Cnut ching reu ðerby.

'Rowed, cnites, noer the land

and here we ther muneches saeng'

O RETORNO DE BEORHTNOTH, FILHO DE BEORHTHELM

Ouve-se o som de um homem que se move de maneira incerta e respira barulhento no escuro. De repente uma voz fala, alta e estridente.

\section{TORHTHELM}

Você! O que faz? Fale! Ao diabo!

TÍDWALD

Totta! Seus dentes a bater conheço! 


\section{TORHTHELM.}

Why, Tída, you! The time seemed long

alone among the lost. They lie so queer.

I've watched and waited, till the wind sighing

was like words whispered by waking ghosts

that in my ears muttered.

TÍDWALD.

And your eyes fancied

barrow-wights and bogies. It's a black darkness

since the moon foundered; but mark my words:

not far from here we'll find the master,

by all accounts.

Tídwald lets out a faint beam from a dark-lantern. An owl hoots. A dark shape flits through the beam of light. Torhthelm starts back and overturns the lantern, which Tída had set on the ground.

What ails you now?

\section{TORHTHELM.}

Lord save us! Listen!

TÍDWALD.

My lad, you're crazed. 


\section{TORHTHELM}

É você, Tída! Parecia que o tempo

se atrasa entre os mortos. Tão estranhos jazem. ${ }^{199}$

Esperei e velei, e o murmurar do vento ${ }^{200}$

era um verso na voz viva de fantasmas

a gemer do meu lado.

\section{TÍDWALD}

\section{E seu olhar sonhou ${ }^{201}$}

sombras e espectros. Há só breu com ${ }^{202}$

a Lua oculta, mas escute o que digo:

é aqui perto que o corpo jaz,

de todo modo.

Tídwald deixa escapar um feixe tênue de luz de uma lanterna escura. Uma coruja pia. Uma forma escura atravessa o feixe de luz. Torhthelm se mexe para trás e emborca a lanterna, que Tída tinha posto no chão.

\section{O que tem você?}

\section{TORHTHELM}

Valha-nos Deus! Ouça!

\section{TÍDWALD}

Está doido, rapaz.

\footnotetext{
${ }^{199}$ A primeira sílaba (com elisão) do verso, "se a-", funciona como anacruse. Várias das meias-linhas do tipo A contam com esse recurso, em freqüência superior à que costuma ser encontrada em anglo-saxão. A concisão menor do português acaba influenciando pesadamente esse aspecto. Aqui também a escansão vai só até a última sílaba acentuada, "já-", procedimento que é adotado ocasionalmente.

${ }^{200}$ Outra característica da tradução que acaba emergindo diretamente da acentuação silábica em português são as tônicas que aliteram, mas não estão no começo das palavras. Aqui, por exemplo "Esperei" na primeira meia-linha alitera com "murmurar" na segunda. A amarração métrica é a mesma, mas quem está acostumado com o estilo em inglês sofre certo desconcerto.

${ }^{201}$ Em alguns casos em que o silêncio ou as marcações de cena se seguem, essa meia-linha isolada significa conclusão de um raciocínio ou transição, mas aqui ela funciona como gancho para o diálogo. Tanto é assim que as duas metades aliteram entre si - a gemer do meu lado/ e seu olhar sonhou. A propósito, $\mathbf{I}$ e lh, pelo parentesco fonético próximo, são consideradas aliterações válidas.

$202 \mathrm{O}$ enjambement, além de ser interessante esteticamente, ajuda a cumprir os requisitos de uma meialinha do tipo $\mathrm{C}$, que pede uma última sílaba átona após o clash das tônicas.
} 
Your fancies and your fears make foes of nothing.

Help me to heave 'em! It's heavy labour

to lug them alone: long ones and short ones,

the thick and the thin. Think less, and talk less

of ghosts. Forget your gleeman's stuff!

Their ghosts are under ground, or else God has them;

and wolves don't walk as in Woden's days,

not here in Essex. If any there be,

they'll be two-leggéd. There, turn him over!

An owl hoots again.

It' s only an owl.

TORHTHELM.

An ill boding.

Owls are omens. But I' m not afraid,

not of fancied fears. A fool call me,

but more men than I find the mirk gruesome

among the dead unshrouded. It's like the dim shadow

of heathen hell, in the hopeless kingdom

where search is vain. We might seek for ever

and yet miss the master in this mirk, Tída.

O lord beloved, where do you lie tonight,

your head so hoar upon a hard pillow,

and your limbs lying in long slumber?

Tídwald lets out again the light of the dark-lantern.

TÍDWALD.

Look here, my lad, where they lie thickest!

Here! lend a hand! This head we know! 
Sua mente e seu medo inimigos criam.

Acuda-me aqui! Coisa difícil ${ }^{203}$

é tal carga erguer; os curtos, compridos,

parcos e polpudos. Pense menos e fale

menos de espectros. Pare com a poesia!

Estão no chão os fantasmas, ou os tem Deus, e

não há lobos como na era de Woden,

não em Essex. Se é que há algum,

vem como bípede. ${ }^{204}$ Vire-o, isso!

Uma coruja pia outra vez.

Uma coruja, é só.

\section{TORHTHELM}

\section{É agourenta.}

Traz má sorte. Mas não tenho receio

de medos inventados. De tolo me chame,

mas não temo a sós a treva horrenda

entre os mortos sem véu. É como a vaga sombra

do inferno pagão, no aflito reino

onde tentar é vão. Seria eterna a busca

sem sinal algum neste negror, Tída.

Oh, mestre amado, onde morto jaz,

cabeça tão branca em coberta fria

e os membros seus em sono sem fim?

Tídwald deixa escapar de novo a luz da lanterna escura.

\section{TÍDWALD}

Amigo, olhe aqui, onde há mais deles!

Acuda cá! Sei de quem é a cabeça!

\footnotetext{
${ }^{203}$ Neste verso e no que aparece acima, torna-se possível a aliteração dupla - o que, no primeiro, ajuda a aliviar o aparente "excesso" causado pela presença de uma sílaba átona a mais no final.
} 
WuIfmær it is. I'll wager aught

not far did he fall from friend and master.

\section{TORHTHELM.}

His sister-son! The songs tell us,

ever near shall be at need nephew to uncle.

\section{TÍDWALD.}

Nay, he's not here - or he's hewn out of ken.

It was the other I meant, th' Eastsaxon lad,

Wulfstan youngster. It's a wicked business

to gather them ungrown. A gallant boy, too, and the makings of a man.

\section{TORHTHELM.}

\section{Have mercy on us!}

He was younger than I, by a year or more.

TÍDWALD.

Here's Ælfnoth, too, by his arm lying.

\section{TORHTHELM.}

As he would have wished it. In work or play they were fast fellows, and faithful to their lord, as close to him as kin.

TÍDWALD.

$$
\text { Curse this lamplight }
$$

and my eyes' dimness! My oath I'll take they fell in his defence, and not far away

\footnotetext{
${ }^{204}$ Usar uma palavra de origem culta e latina como essa não é a melhor escolha, em condições ideais, para esse tipo de poema, mas pelo menos a ocorrência desse tipo de vocábulo está bastante minimizada.
} 
De Wulfmær ela é. Quase hei de jurar que perto do mestre e amigo tombou.

\section{TORHTHELM}

O filho-da-irmã! ${ }^{205}$ Falam-nos os cantos:

sempre perto ao lutar vão tio e sobrinho.

\section{TÍDWALD}

Não, não é ele, ou dele nada sobrou:

penso que é o outro, o rapaz de Essex,

filho de Wulfstan. Um fado cruel

leva-os assim logo. Valente o menino,

com ares de homem.

\section{TORHTHELM}

\section{Misericordioso ${ }^{206}$ Deus!}

Eu sou mais velho, por um ano ou mais.

\section{TÍDWALD}

Eis também Ælfnoth, junto ao braço seu.

\section{TORHTHELM}

Foi como ele quis. Em brinquedo ou labor

companheiros leais, e ao senhor fiéis,

feito irmãos dele.

TÍDWALD

Ao demônio esta luz

e minha turva visão! Quase estou certo

de que na defesa final foram mortos

\footnotetext{
205 "Sobrinho" jamais seria um equivalente decente para a expressão "sister-son", que aliás aparece também em O senhor dos anéis entre o povo de Rohan.

${ }^{206}$ Mais um exemplo de aliteração que provavelmente nunca ocorreria em anglo-saxão ou inglês moderno: o hiato de misericordioso "rima" com as outras vogais tônicas do verso (presentes na fala do personagem na linha acima).
} 
now master lies. Move them gently!

\section{TORHTHELM.}

Brave lads! But it's bad when bearded men

put shield at back and shun battle,

running like roe-deer, while the red heathen

beat down their boys. May the blast of Heaven

light on the dastards that to death left them

to England's shame! And here's Ælfwine:

barely bearded, and his battle's over.

TÍDWALD.

That's bad, Totta. He was a brave lordling, and we need his like: a new weapon

of the old metal. As eager as fire,

and as staunch as steel. Stern-tongued at times, and outspoken after Offa's sort.

\section{TORHTHELM.}

Offa! he's silenced. Not all liked him; many would have muzzled him, had master let them.

'There are cravens at council that crow proudly with the hearts of hens': so I hear he said at the lords' meeting. As lays remind us:

'What at the mead man vows, when morning comes let him with deeds answer, or his drink vomit and a sot be shown.' But the songs wither, and the world worsens. I wish I'd been here, not left with the luggage and the lazy thralls, cooks and sutlers! By the Cross, Tída, I loved him no less than any lord with him; and a poor freeman may prove in the end more tough when tested than titled earls who count back their kin to kings ere Woden. 
e que o mestre está aqui. Mexa-os com calma!

\section{TORHTHELM}

Bravos moços! Mau é ver homens

que às costas põem broquel e correm da batalha, céleres feito cervos, enquanto os sujos pagãos rasgam seus meninos. Possa um raio dos céus os bastardos queimar que à morte os deixaram pra pejo dos anglos. E este é Ælfwine:

mal tem barba e já não se bate mais.

\section{TÍDWALD}

Isso é mau, Totta. Tinha destemor o lordezinho como outros não têm: arma nova do ferro antigo. Fero como chama, duro como aço. Ácido às vezes, boca-rota, lembrando Offa.

\section{TORHTHELM}

Offa! Está em silêncio. Poucos lordes o amavam.

Muitos o calariam, se o mestre deixasse.

“Os poltrões aqui trilam faceiros

co'audácia de galinhas"; dizem ser sua fala

aos lordes reunidos. É como as lais cantam:

“O que jurar ébrio, quando a aurora vier

cumpra seu voto, ou seu vinho vomite, como tolo que é". Mas as cantigas morrem, e o mundo decai. Aqui queria estar, e não ficar pra trás com os lacaios vadios, mascates e cozinheiros! Pela Cruz, Tída, eu o amava mais que muitos desses nobres; e um pobre livre na luta pode ser mais duro no fim que fidalgos de escol cuja raça vem de reis antes de Woden. 


\section{TÍDWALD.}

You can talk, Totta! Your time'll come, and it'll look less easy than lays make it.

Bitter taste has iron, and the bite of swords is cruel and cold, when you come to it.

Then God guard you, if your glees falter!

When your shield is shivered, between shame and death is hard choosing. Help me with this one!

There, heave him over - the hound's carcase,

hulking heathen!

\section{TORHTHELM.}

Hide it, Tída!

Put the lantern out! He's looking at me.

I can't abide his eyes, bleak and evil

as Grendel's in the moon.

TÍDWALD.

Ay, he's a grim fellow, but he's dead and done-for. Danes don't trouble me save with swords and axes. They can smile or glare, once hell has them. Come, haul the next!

\section{TORHTHELM.}

Look! Here's a limb! A long yard, and thick as three men's thighs.

TÍDWALD.

$$
\text { I thought as much. }
$$

Now bow your head, and hold your babble for a moment Totta! It's the master at last. 


\section{TÍDWALD}

Conversa, Totta! Vai vir sua hora,

e menos leve há de ser do que as lais ${ }^{207}$ dizem.

Sabe a fel ferro, e morde fundo a espada

alva e fria, quando a hora vem.

Valha-te então Deus, se a verve faltar!

Quando o escudo se quebra, a escolha é dura,

morte ou vergonha. Dê uma mão co'este!

Aqui, vire-o - carcaça de bicho,

nojento gentio! ${ }^{208}$

\section{TORHTHELM}

Tída, cubra-o!

Tire a luz daí! Ele olhou pra mim.

Olhos insuportáveis, ocos e maldosos

qual os de Grendel à lua.

TÍDWALD

$$
\text { É, fulano feio, }
$$

Mas nada faz mais. Daneses só matam

co'espadas e machados. Por mim, podem sorrir,

se o diabo os levou. Vamos, puxe o outro!

\section{TORHTHELM}

Veja! Um membro! Mede uma jarda, grosso como três coxas.

\section{TÍDWALD}

\section{Agora vi.}

Incline a cabeça, cale a matraca

um momento, Totta! É o mestre, enfim.

\footnotetext{
${ }^{207}$ A palavra também existe, pouquíssimo alterada, em português.

${ }^{208}$ Há quem sugira uma conexão entre heathen e o grego êthnos. Se for verdade, o uso de "gentio" é ainda mais adequado, já que o termo latino do qual a palavra se origina também tem esse significado.
} 
There is silence for a short while.

Well, here he is - or what Heaven's left us:

the longest legs in the land, I guess.

\section{TORHTHELM.}

(His voice rises to a chant.)

His head was higher than the helm of kings

with heathen crowns, his heart keener

and his soul clearer than swords of heroes

polished and proven; than plated gold

his worth was greater. From the world has passed

a prince peerless in peace and war,

just in judgement, generous-handed

as the golden lords of long ago.

He has gone to God glory seeking,

Beorhtnoth beloved.

TÍDWALD.

Brave words, my lad!

The woven staves have yet worth in them

for woeful hearts. But there's work to do, ere the funeral begins.

\section{TORHTHELM.}

I've found it, Tída!

Here's his sword lying! I could swear to it

by the golden hilts.

TÍDWALD.

I'm glad to hear it.

How it was missed is a marvel. He is marred cruelly.

Few tokens else shall we find on him;

they've left us little of the lord we knew. 
Faz-se silêncio por um curto instante

Bem, cá o temos, ou o que o bom céu deixou:

pernas mais compridas por perto não há.

\section{TORHTHELM}

( $A$ voz dele se ergue num cântico)

Alta era sua fronte mais que elmo de reis

com coroas pagãs, mais feroz coração

e pura alma que espadas fiéis

postas à prova; peças de ouro

vence em preço. Perde o mundo

príncipe sem-par em paz ou guerra,

mente justa, mão aberta,

qual nobres eram noutros tempos.

Leva-o Deus na luz da glória,

Beorhtnoth amado.

TÍDWALD

Bravo, menino!

A trama das trovas inda tem valor

para um peito em pesar. Mas não é pouco o trabalho

antes do enterro.

TORHTHELM

Encontrei, Tída!

Eis sua espada aqui! Até posso jurar

pelo punho que reluz.

TÍDWALD

Alegra-me saber.

Por milagre não a tomam. Seu estado é cruel.

Outras provas não hemos de achar:

Restou pouco do patrão que foi. 


\section{Conclusão}

Em cada uma das traduções dos quatro textos tolkienianos apresentadas acima, creio ser possível discernir uma linha de pensamento clara, um espírito norteador que ajudou a guiar as opções (às vezes, é forçoso admitir, verdadeiras escolhas de Sofia) inerentes a um trabalho desta natureza. Minha convicção, portanto, é de que as traduções falam por si mesmas. No entanto, esta conclusão fornece a oportunidade de unificar essa experiência e, quem sabe, extrair as lições que ela é capaz de ensinar.

Não há porque negar o fato de que a raiz deste projeto sempre foi o desejo de seguir um dos conselhos mais sábios dos tradutores da era Augustan: é saudável e produtivo balizar a tradução na afinidade de temas e estilo entre tradutor e autor traduzido. Na verdade, o objetivo um tanto megalomaníaco e utópico era resolver, talvez, a própria insatisfação que eu tinha com as traduções de Tolkien em português, por competentes que fossem: a vontade de fazer um texto tolkieniano traduzido soar, mesmo em português, como o original; a de fazer Tolkien traduzido ainda soar como Tolkien.

Desde então, como brinca o autor em uma de suas cartas, "minha crista há muito caiu". Essa avaliação, porém, não significa que eu não considere esse objetivo alcançado. Enfrentar diretamente o problema inevitavelmente trouxe uma consciência nova sobre o intrincado jogo de perde-e-ganha que a tradução comporta. Se me é permitido tomar de empréstimo a bela metáfora da "luz refratada" da sub-criação humana, que Tolkien utiliza em Mythopoeia, o complicado balé que entrelaça dois idiomas na tradução de um texto, ainda que o par seja razoavelmente aparentado, como o inglês e o português, opera transformações quase alquímicas, que nós jamais teríamos sido capazes de prever antes de começar. Com efeito, é assim, em larga medida, que tradições literárias se enriquecem e se transformam, incorporando termos aparentemente tão alienígenas quanto "Feéria" ou abrigando em seu interior formas surgidas em outro contexto lingüístico e histórico, como a rima aliterativa anglo-saxã. A tentativa de usar esse metro tão fascinante e peculiar em português e as inevitáveis transformações que permitiram o meu sucesso (ainda que, talvez, qualificado; deixo esse julgamento ao leitor) provavelmente não difere essencialmente do que os poetas ingleses fizeram ao "insularizar" o soneto italiano pela primeira vez. O desafio foi estimulante, mas também exaustivo: de todos os textos da coletânea, Homecoming foi o único que não pude 
apresentar na forma integral da tradução, justamente pela dificuldade muito considerável que tal métrica comporta.

Em última instância, é essa abertura de possibilidades praticamente infinitas da língua e do mito que a sub-criação tolkieniana celebra, e espero ter mostrado que a tradução é capaz de permitir que o vento de Feéria sopre no coração de outra língua e de outra cultura. A estranheza talvez seja um preço pequeno a se pagar por essa perspectiva de renovar a Criação por meio da palavra, como Tolkien tanto almejava. 


\section{Fontes Consultadas}

ABAURRE, Maria Bernadete e GALVES, Charlotte. As diferenças rítmicas entre o português europeu e o português brasilero: uma abordagem otimalista e minimalista. In DELTA (Documentação de Estudos em Lingüística Teórica e Aplicada), vol. 14, n 2, 1998.

BASSETTO, Bruno Fregni. Elementos de filologia românica. São Paulo: Edusp, 2001. $380 \mathrm{p}$.

BENJAMIM, Walter. A tarefa - renúncia do tradutor. In Clássicos da teoria da tradução - antologia bilíngüe alemão-português. Florianópolis: Núcleo de Tradução, UFSC, 2001.

Beowulf: a new verse translation by Seamus Heaney - bilingual edition. Nova York: W.W. Norton \& Company, 2000. 213 p.

BERMAN, Antoine. A prova do estrangeiro: Cultura e tradição na Alemanha romântica - Herder, Goethe, Schlegel, Novalis, Humboldt, Schleiermacher, Hölderlin. Bauru: EDUSC, 2001. 350 p.

. Translation and the trials of the foreign. In The translation studies reader. 1. ed. Nova York: Routledge, 2000. 544 p.

BISOL, Leda. O troqueu silábico no sistema filológico (um adendo ao artigo de Plínio Barbosa). In DELTA (Documentação de Estudos em Lingüística Teórica e Aplicada), vol. 16, n. 2, 2000, p. 403-413.

CAGLIARI, Luiz Carlos e MASSINI-CAGLIARI, Gladis. Quantidade e duração silábicas em português do Brasil. In DELTA (Documentação de Estudos em Lingüística Teórica e Aplicada), vol. 14 (edição especial). São Paulo: 1998.

CARPENTER, Humphrey. J.R.R. Tolkien: Uma biografia. 1. ed. São Paulo: Martins Fontes, 1994. 
. The Inklings: C.S. Lewis, J.R.R. Tolkien, Charles Williams and their friends. Londres: Harper Collins, 1997. 287 p.

. The letters of J.R.R. Tolkien. Londres: Harper Collins, 1995. 502 p.

CARTER, Lin. O senhor do Senhor dos Anéis: o mundo de Tolkien. Rio de Janeiro: Record, 2003. 219 p.

DIAMOND, Robert. Old English grammar and reader. Detroit: Wayne State University Press, 1970. 304 p.

DROUT, Michael D.C. Tolkien's prose style and its literary and rhetorical effects. In Tolkien studies, vol. 1, 2004, p. 137-162.

EVEN-ZOHAR, Itamar. The position of translated literature within the literary polysystem. In The translation studies reader. 1. ed. Nova York: Routledge, 2000. $544 \mathrm{p}$.

FAUSKANGER, Helge Kare. Curso de Quenya - a mais bela língua dos elfos. Curitiba: Arte \& Letra, 2004. 445 p.

GODDEN, Malcolm e LAPIDGE, Michael (org.). The Cambridge companion to Old English literature. Cambridge: Cambridge University Press, 1991. 298 p.

LAGES, Susana Kampf. “A tarefa do tradutor” e o seu duplo: a teoria da linguagem de Walter Benjamin como teoria da traduzibilidade. In Cadernos de tradução, n. 3. Florianópolis: Editora da Universidade Federal de Santa Catarina, 1998, p. 63-88.

LEFEVERE, André. Literary theory and translated literature. In Dispositio, vol. VII, n. 19-20 (1982), p. 3-22. . Mother Courage's cucumbers: text, system and refraction in a theory of literature. In The translation studies reader. 1. ed. Nova York: Routledge, 2000. 544 p. 
MILTON, John. Tradução: teoria e prática. 2. ed. São Paulo: Martins Fontes, 1998. $248 \mathrm{p}$.

MITCHELl, Bruce e ROBINSON, Fred C. A guide to Old English. 5. ed. Oxford: Blackwell, 1992. 375 p.

ONIONS, C.T. (ed.). The Oxford dictionary of English etymology. Nova York: Oxford University Press, 1966. 1023 p.

ORTEGA Y GASSET, José. Miseria y esplendor de la traducción. In Obras completas, 1. ed. Madrid: Revista de Occidente, 1947, vol. V.

PINKER, Steven. O instinto da linguagem: Como a mente cria a linguagem. 1. ed. São Paulo: Martins Fontes, 2002. 627 p.

PYM, Anthony. The return to ethics (special issue). In The translator - studies in intercultural communication, vol. 7, n. 2 (2001), p. 130-167.

QUIRK, Randolph e WRENN, C.L. An Old English Grammar. Nova York: Holt, Rineheart \& Winston, 1957. 166 p.

SHIPPEY, Tom. J.R.R. Tolkien - author of the century. Londres: Harper Collins, 2001. $347 \mathrm{p}$.

SILVA, Thaïs Cristófaro. Fonética e fonologia do português. São Paulo: Contexto, 2005. $275 \mathrm{p}$.

The road to Middle-earth: how J.R.R. Tolkien created a new mythology. Londres: Harper Collins, 1992. 337 p.

STEINER, George. After Babel: Aspects of language and translation. Oxford: Oxford University Press, 1977. 507 p. 
TOLKIEN, J.R.R. Tree and leaf. Londres: Harper Collins, 2001. 150 p.

. The Tolkien reader: stories, poems and commentaries by the author of The Hobbit and The Lord of the Rings. Nova York: Ballatine Books, 1966. 251 p.

. The lord of the rings. Londres: Harper Collins, 1995. 1137 p.

. Tales from the perilous realm. Londres: Harper Collins, 1998. 178 p.

. The monsters \& the critics and other essays. Londres: Harper Collins, 1997. $240 \mathrm{p}$.

TOURY, Gideon. The nature and role of norms in translation. In The translation studies reader. 1. ed. Nova York: Routledge, 2000. 544 p.

TYMOCZKO, Maria. Translation and Political Engagement. In The translator, vol. 6, n. 1 (2000), p. 23-47.

VENUTI, Lawrence. Rethinking translation: discourse, subjectivity, ideology. Nova York: Routledge, 1992. 235 p. 